\begin{tabular}{|l|l|}
\hline 2. To: (Receiving organization) & $\begin{array}{l}\text { 3. From: (Originating Organization) } \\
\text { TWRS Projects/SST Retrieval }\end{array}$ \\
\hline 5. Proj./Prog./Dept./Div.: D299/ & $\begin{array}{l}\text { 6. Design Authority/ Design Agent/Cog. } \\
\text { Engr:: } \\
\text { W-320 TWRS/TCPN \# Bailey, NHC }\end{array}$ \\
\hline
\end{tabular}

8. Originator Renarks:

For approval and release of a new supporting document. This document has been generated to ensure retrievability of the Project W-320 "Electrical Calculations, Vol. 2".
11. Receiver Remarks:
11A. Design Basel ine Document?
[X] Yes
[] No

4. Related EDT No.:

$n / a$

7. Purchase Order No.:

$\mathrm{n} / \mathrm{a}$

9. Equip./Component No.:

$\mathrm{n} / \mathrm{a}$

10. System/Bldg./Facil ity:

241-C-106

12. Major Assm. Dwg. No.:

$\mathrm{n} / \mathrm{a}$

13. Permit/Permit Application No.: $n / a$

14. Required Response Date:

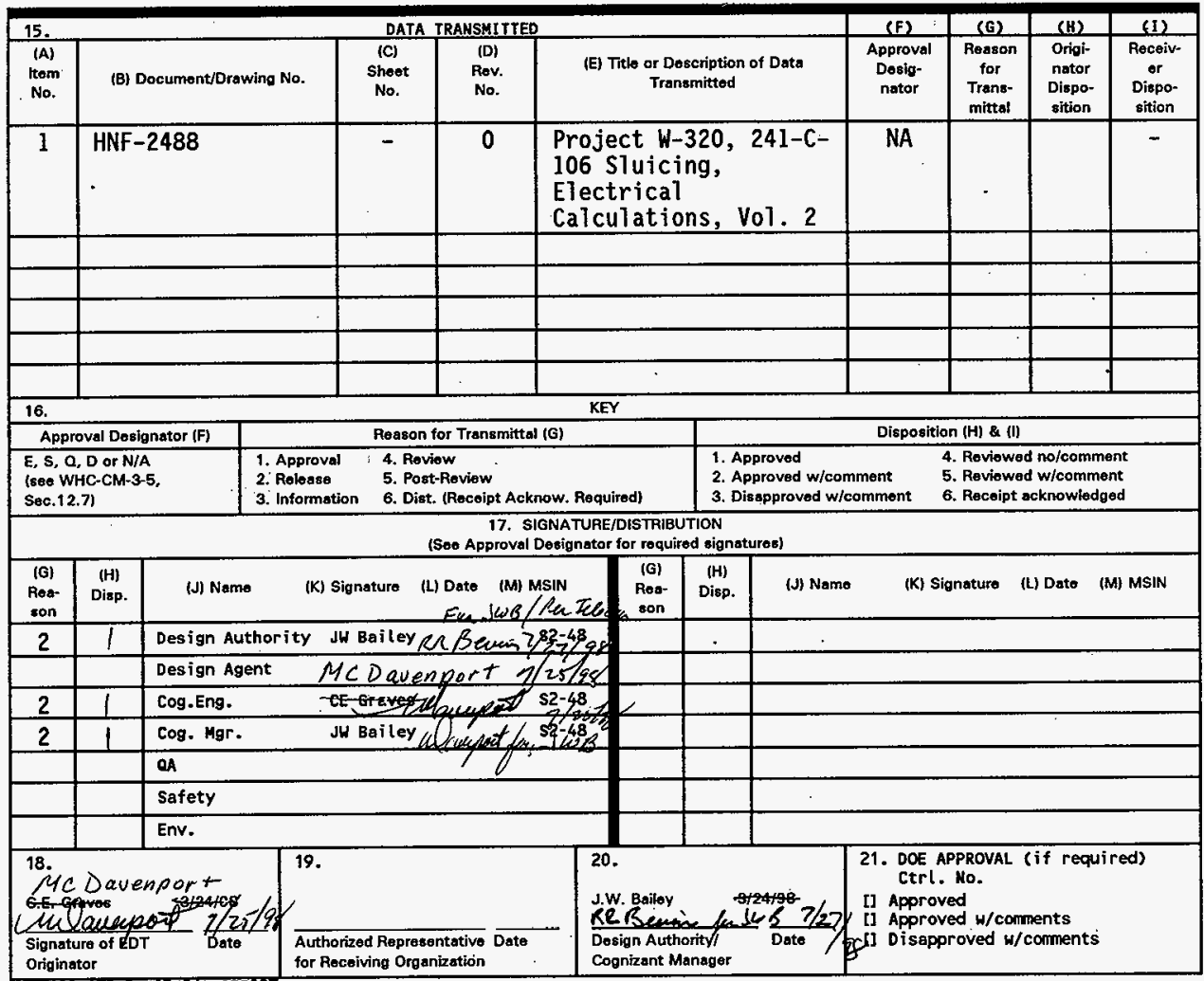

BD-7400-172-2 (05/96) GEF097 


\section{Project W-320, 241-C-106 Sluicing Electrical Calculations, Vol. 2}

John W. Bailey

Numatec Hanford Co., Richland, WA 99352

U.S. Department of Energy Contract DE-AC09-96RL13200

EDT/ECN : 622246

Org Code: $8 \mathrm{C} 452$

B\&R Code: EW3130010
UC: 506

Charge Code: D2991/HANA0600

Tota7 Pages: $14 /$

Key Words: W-320, Sluicing, Tank 241-C-106, Tank 241-AY-102, WRSS, calculations, Electrical.

Abstract: This supporting document has been prepared to make the FDNW calculations for Project $W-320$, readily retrievable.

TRADEMARK DISCLAIMER. Reference herein to any specific commercial product, process, or service by trade name, trademark, manufacturer, or otherwise, does not necessarily constitute or imply its endorsement, recommendation, or favoring by the United states Government or any agency thereof or its contractors or subcontractors.

Printed in the United States of Anerica. To obtain copies of this document, contact: Document control Services, P.0. 80x 950, Mailstop H6-08, Richland WA 99352, Phone (509) 372-2420; Fax (509) 376-4989.

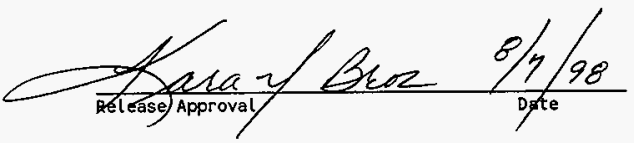

Approved for Public Release
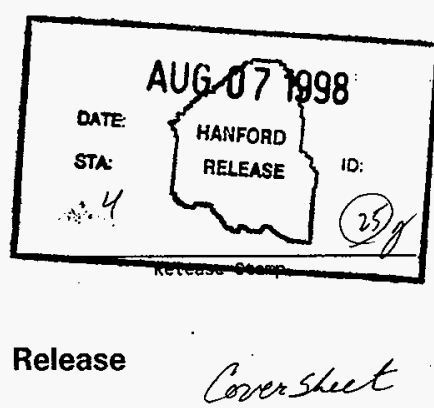

page $1 / 22$ 


\section{APPLICATION FOR PERMISSION TO USE YOUR CŌPYRIGHTED MATERIAL}

To! Rockbestos

Attn: Donna Argento

Date: $8 / 3 / 98$

Permission Is requested to peproduce the fallowing ropyfighted inaterial from:

your catalog

Selections from text (specify by date of issue, page, paragraph, or illustration; if desired, attzch a copy of the material in question):

see attached four (4) pages

Title of work or project in which this material will be included:

Control Circuit Sizing \& Voltage Drop Analysis for Seismic Shutdown 5ystem Specification Document

Estimated publication date: $8 / 8 / 98$

Author: D.E. Evans

Publisher (if applicabiel: Hanford Site, Richland, Washington

If the copyrighted material is not to be used in a published work, plesse provide a brief description of how it is to bo used: -

\begin{tabular}{|c|c|c|c|c|}
\hline \multicolumn{2}{|c|}{ 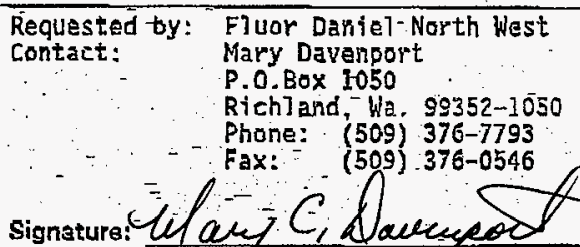 } & MSIN: $\begin{array}{c}\text { S2-48 } \\
- \\
\vdots\end{array}$ & Date: & $8 / 3 / 58$ \\
\hline
\end{tabular}

Permission is granted $X$ denied - to use-requested materials:

Company Name: Rock bestos-Surpment'Coble Coxp Signatory's Position: CSR

signature: Doxinenh Argenta - - (on behalf of RSCC 


\title{
Project W-320, 241-C-106 Sluicing Electrical Calculations, Vol. 2
}

\author{
TABLE OF CONTENTS
}

$\begin{array}{llc}\text { Calc. No. } & \text { Title } & \text { Page } \\ \text { W320-31-014 } & \text { C-Farm Electrical Heat Tracing } & \text { A- } \mathbf{~} \\ \text { W320-31-015 } & \begin{array}{l}\text { Cable Ampacity, Lighting, Conduit } \\ \text { Fill \& Voltage Drop }\end{array} & \text { B-i } \\ \text { W320-31-022 } & \begin{array}{l}\text { Control Circuit Sizing \& Voltage } \\ \text { Drop Analysis for Seismic } \\ \text { Shutdown System (Class 1E) }\end{array} & \text { C-i }\end{array}$


HNF-2488, Rev. 0

W320-31-014

C-Farm Electrical Heat Tracing

$A-\mathbf{i}$ 
This sheet shows the status and description of the attached Design Analysis sheets.
Discipline Electrical
wo/Job No. ER4319

Calculation No. W320-3l-014

Project No. \& Name W-320 Tank 241-C-106 Sluicing

calculation Item C-Farm Electrical Heat Tracing

These calculations apply to:

Dwg. No. H-2-818678, Sh. 3

Rev. No. 0

Dwg. No. $\mathrm{H}-2-818690$

Rev. No. 0

other (Study, CDR)

Rev. No.

The status of these calculations is:

[] Preliminary calcutations

[X] Finat Calculations

[] Check Calculations (on Calculation Dated)

[] Void Calculation (Reason Voided)

Incorporated in Final Drawings?

[X] Yes [] No

This calculation verified by independent "check" calculations? [] Yes [X] No

Original and Revised Catculation Approvals:

\begin{tabular}{|c|c|c|c|}
\hline & $\begin{array}{c}\text { Rev. } 0 \\
\text { signature/Date }\end{array}$ & $\begin{array}{c}\text { Rev. } 1 \\
\text { Signature/Date }\end{array}$ & $\begin{array}{c}\text { Rev. } 2 \\
\text { Signature/Date }\end{array}$ \\
\hline originator & $\mathrm{R} \mathrm{H}_{\mathrm{H}}$ & & \\
\hline checked by & & & \\
\hline Approved by & & & \\
\hline $\begin{array}{l}\text { Checked Against } \\
\text { Approved Vendor Data }\end{array}$ & 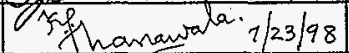 & & \\
\hline
\end{tabular}

APPROVED VENDOR DATA NOT AVALLALE. VERIFIED THAT HEAT-TRACE ITEMS WERE ACQVIRED IN FIELD PER

MATERIAL LIST ON DWG.H.2-818569, SH.I 2 AND INDEX HEAT.TRACE WAS INSTALLED PER PESIGN ON DWG.

Design Analysis Description

$H \cdot 2-818678,5 H \cdot 3$

Page No.

\begin{tabular}{|c|l|}
\hline$i$ & Calculation Identification and Ind \\
\hline$i \mathrm{i}$ & Calculation Cross Index \\
\hline 1 & Objective; Design Inputs; Given Dat \\
\hline 2 & Method of Analys is; References \\
\hline $2-6$ & Calculations \\
\hline 6 & Conclusions \\
\hline A-1 To A-16 & Appendix A: 0'Brien Corp. "Trace \\
\hline B-1 To B-17 & Appendix B: Raychem Corp. "Cheme \\
\hline C-1 To C-8 & Appendix C: Vendor Heat Tracing \\
\hline & \\
\hline & \\
\hline & \\
\hline
\end{tabular}

HNF-2488, Rev. 0

Page A-1 


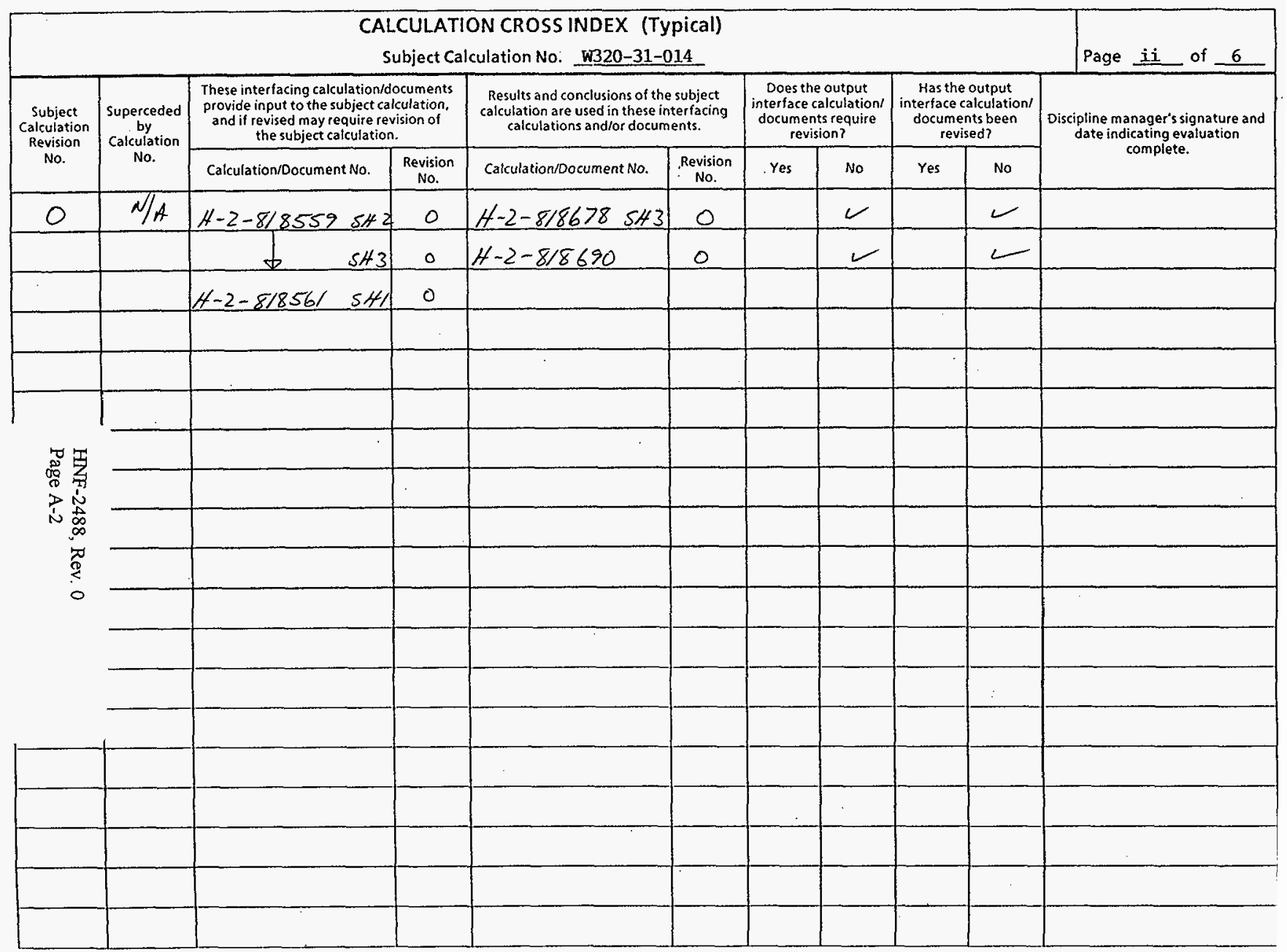

KEH $1975.00(12 / 88$ 


\section{DESIGN ANALYSIS}

Client WHC

subject C Farm Electrical Heat Tracing Systems

Location $200 \mathrm{E}, \mathrm{C}$ Farm
Calc. No. W320-31-014

Revision 0

Page No. 1 of 6

wo/Job No. W-320

Date $9 / 19 / 95$

Checked $9 / 27 / 95$

Revised

By R.H. Graeber

By S.A. Najjar $\leqslant \cdot N$.

By

\subsection{OBJECTIVE}

1.1 To determine the power requirements needed to power electrical heat tracing segments contained within three manufactured insulated tubing assemblies. To verify thermal adequacy of tubing assembly selection by others.

1.2 To size the heat tracing feeder and branch circuit conductors \& conduits. To size protective circuit breaker and fuses.

1.3 To accomplish thermal design for two electrical heat tracing segments: One o C -106 tank riser 7 (CCTV) and one at the exhaust hatchway (condensate drain).

\subsection{DESIGN INPUTS}

2.1 Drawing H-2-818559, Shts. 2 \& 3, P\&ID Tank 241-C-106.

2.2 Drawing H-2-818561, Shts, 1, P\&ID Tank 241-C-106 HVAC.

2.3 NFPA-70, National Electrical Code (1993 edition).

2.4 "In Tank" CCTV, WHC Purchase Requisition No. 422301.

\subsection{GIVEN DATA}

3.1 Al1 electrical heat tracing provided by others as a part of tubing assemblies sha11 be powered by a 120 VAC, 1 phase source.

3.2 All electrical heat tracing shall be for freeze protection only. Need to maintain process piping at 40 Deg $F$ minimum.

3.3 Minimum ambient temperature est. to be -20 Deg. F., maximum ambient temperature estimated at $110 \mathrm{Deg}$. F.

3.4 Location to be outdoors and/or buried 12 inches below grade.

3.5 Field installed piping insulation to be $1 / 2$ inch thick fiberglass (ASTM C547-77) with maximum "K" factor at 50 Deg. $F$. to be 0.2497 BTU-IN/HR-SQ FT-Deg.F.

\subsection{ASSUMPTIONS}

4.1 Estimated duration for this project is two years.

4.2 Electrical power is supplied from a panelboard source at 120 VAC $(+$ or $-10 \%)$. 
KAISER ENGINEERS

HANFDRD

DESIGN ANALYSIS

client WHC

subject C Farm Electrical Heat Tracing Systems

Design

Location 200 E, C Farm
Calc. No. W320-3I-014

Revision0

Page No. 2 of 6

Wo/Job No. $W-320$

Date $9 / 19 / 95$

Checked $9 / 27 / 95$

Revised
By R.H. Graeber

By S.A. Najjar $S \cdot N$,

\subsection{METHOD OF ANALYSIS}

\subsection{Hand caiculations}

\subsection{REFERENCES}

6.1 H-2-818569, Sht. 1, material list.

6.2 O'Brien Corporation "Tracepak" catalog application guide.

6.3 Raychem "Chemelex" heat tracing systems catalog design guide for insulated pipes and tubing.

6.4 NFPA-70, National Electrical Code (1993 edition).

\subsection{CALCULATION}

7.1 Description of tubing/piping systems to be protected and any heat tracing supplied by others.

\begin{tabular}{|c|c|c|c|c|}
\hline Mech. System & Location & Dia. & Length & InsuTatjon \\
\hline $\begin{array}{l}7.1 .1 \\
1-752-131\end{array}$ & Underground \& outdoor & 0.511 & $25 \mathrm{ft}$. & $\begin{array}{l}\text { O'Brien single tracepak } \\
\text { (TPEY) with 5BTV1 Chemelex } \\
\text { tracing. }\end{array}$ \\
\hline $\begin{array}{l}7.1 .2 \\
I A(20 \#)-704-131\end{array}$ & Underground \& Outdoor & $0.5^{\prime \prime}$ & $25 \mathrm{ft}$ & $\begin{array}{l}\text { O'Brien single tracepak } \\
\text { (TPE2) with 5BTV1 Chemelex } \\
\text { tracing. }\end{array}$ \\
\hline $\begin{array}{l}7.1 .3 \\
\text { FW }-626-131 \text { and } \\
\text { IA(20\#)-705-131 } \\
\text { (to CCTV a } R-7)\end{array}$ & $\begin{array}{l}\text { Underground \& } \\
\text { Outdoor }\end{array}$ & $\begin{array}{l}0.5^{\prime \prime} \\
0.5^{\prime \prime}\end{array}$ & $90 \mathrm{ft}$. & $\begin{array}{l}\text { o:Brien dual tracepak with } \\
\text { single } 5 \text { BTV1 Chemelex } \\
\text { tracing. }\end{array}$ \\
\hline $\begin{array}{l}7.1 .4 \\
\text { Fiex tubing \& } \\
\text { upper junction } \\
\text { box a CCTV }(R-7)\end{array}$ & outdoors & $\begin{array}{l}\text { (see } \\
7.1 .3)\end{array}$ & $\begin{array}{l}\text { Two } 5 \mathrm{ft} \text {. } \\
\text { long flex } \\
\text { tubes. }\end{array}$ & $\begin{array}{l}0.5 \text { " thick fiber glass with } \\
\text { PVC jacket. "K" }=0.2497\end{array}$ \\
\hline $\begin{array}{l}7.1 .5 \\
D R-305-M 9\end{array}$ & Outdoors & $0.75^{\prime \prime}$ & $10 \mathrm{ft}$. & $\begin{array}{l}0.5 \text { " thick fiber glass with } \\
\text { PVC jacket. "K" }=0.2497\end{array}$ \\
\hline
\end{tabular}

HNF-2488, Rev. 0

Page A-4 


\section{DESIGN ANALYSIS}

client WHC

subject C Farm Electrical Heat Tracing Systems Design

Location 200 E, C Farm
Revision 0

Page No. 3 of 6

Wo/Job No. W-320

Date $9 / 19 / 95$

Checked $9 / 27 / 95$

Revised
By R.H. Graeber

By S.A. Najjar S.N.

By

7.2 Analysis of electrical heat tracing supplied by others (see $\mathrm{H}-2-818569$ ).

7.2.1 Mechanical systems identified in 7.1.1, 7.1.2 \& 7.1.3 are protected by electrical heat tracing supplied by others. Notice that 7.1 .1 \& 7.1.2, although in different service, are identical.

a) On page 6 of reference 6.2, the TPEI Chart confirms that the 5BTVI type chemelex heat tracing is adequate for the "single" tube freeze protection. The "5 watt/ft" tracer maintains the "TPE1" single, $0.5^{\prime \prime}$ process 1 ine at $60 \mathrm{Deg}$. F. given a $-20 \mathrm{Deg}$. F. ambient temperature.

b) Again on page 6 of ref. 5.2, the TPE2 Chart confirms that the 5BTVI type Chemelex heat tracing is adequate for the "dual" tube freeze protection. The " 5 watt/ft" tracer maintains the "TPE2" double, $0.5^{\prime \prime}$ process 1 ines at $55(+$ or - ) Deg. F. given a -20 Deg. F. ambient temperature.

7.3 Determination of electrical tracer requirements installed on tubing \& pipes in the field (by ICFKH).

7.3.1 Heat tracing requirements for mechanical systems identjfied in 7.1 .4 and 7.1 .5 are to be determined by this calculation section.

7.3.2 Calculation for 7.1.4 (from ref. 6.3)

a) Temperature differentia = maintained temperature - lowest ambient temperature.

$$
\underline{\underline{\text { Diff })}}=40-(-20)=60 \text { Deg. F. }
$$

b) From Chart I, pipe heat loss equals approximately 2.3 watts per foot for $T$ (Diff) $=60$, Insulation Thickness $=0.5^{\prime \prime}$ and Flexible Tubing Size $=0.5$ ".

$$
\text { [Interpolation: } \left.1.9+\frac{(60-50)}{(100-50)}(3.9-1.9)=2.3\right]
$$

c) Also from the bottom of page 2 at Chart 1, the insulation factor for fiber glass insulation is 1.0 .

d) The net pipe heat loss is 2.3 watts $/ \mathrm{ft} \times 1.0=2.3$ watts $/ \mathrm{ft}$.

e) Selection of tracer sizing is accomplished. using Chart $3 \mathrm{a}$. Chemelex 3BTVI tracer would provide 3.4 watts per foot at $40 \mathrm{Deg} F$. To increase the degree of certainty and to assjst in heating the upper junction box, upsize the tracer to a "5BTV1". This has the 


\section{DESIGN ANALYSIS}

client WHC

subject C Farm Electrical Heat Tracing Systems

Design

Location 200 E, C Farm
Calc. No. W320-31-014

Revision0

Page No. 4 of 6

wo/Job No. W-320

Date $9 / 19 / 95$

Checked $9 / 27 / 95$

Revised
By R.H. Graeber

By S.A. Najjar S. N.

BY

additional advantage of matching the "TPE 2 " tracer (being sliced onto). Two flexible tube assemblies each approximately 5 feet long are expected.

f) Chemlex "5BTV1" tracer wi11 deliver 5.6 watts/foot 80 Deg F. Best guess is that the CCTV upper junction box will be fabricated by the vendor from a $12^{\prime \prime}$ long section of. $12^{\prime \prime}$ dia. pipe (same as the $12^{\prime \prime}$ dia. pipe in Chart 1). From Chart 1 for T(Diff.) $=60$, pipe dia.

$=12^{\prime \prime}$ and insulation thickness $=0.5^{\prime \prime}$, the pipe heat loss is:

$$
25.2+\frac{(60-50)}{(100-50)}(52.5-25.2)=30.66 \text { watts } / \text { foot }
$$

30.66 watts/foot $\times 1.0$ insulation factor $X 1$ foot length $=31$ watts heat loss thru the junction box side walls.

Sidewall surface area $\left.=\pi \mathrm{dh}=(\pi)\left(1^{1}\right) 1^{1}\right)=3.14 \mathrm{sq} . \mathrm{ft}$.

Top \& bottom surface area $=2\left[\pi r^{2}\right]=2 \pi(0.5)^{2}=1.57 \mathrm{sq}$. ft.

Will add $50 \%$ for heat loss thru junction box top/bottom.

Total heat loss $=(1.5) 30.66=46$ watts

At 5.6 watts/foot deliverable, we will need 46 watts $/ 5.6$ watts/foot $=8.2$ feet (min.) of chemelex "5BTV1. tracer wrapped around the upper junction box. Will add 50\% to this footage to ensure adequate coverage. Wrap 12 feet (tor - ) around the CCTV upper junction box. Approximately $\underline{\underline{4} \text { wraps }}$ are involved.

\subsubsection{Calculation for 7.1 .5 (from ref. 6.3)}

a) $T$ (Diff.) is the same as $7.3 .2 \mathrm{a}=60 \mathrm{Deg}$. F.

b) From Chart 1 for $T($ Diff. $)=60$, pipe dia. $=0.75^{\prime \prime}$ and insulation thickness $=0.5^{\prime \prime}$, the pipe heat loss

$$
=2.9+\frac{(60-50)}{(100-50)}(6.1-2.9)=3.54 \text { watts } / \text { foot } \text {. }
$$

c) 3.54 watts/foot $\times 1.0$ insulation factor $=3.54$ watts $/$ foot.

d) Again, select Chemelex "5BTV1" tracer (5.6 watts/foot (a $40^{\circ} \mathrm{F}$ ).

HNF-2488, Rev. 0

Page A-6 


\section{KAISER ENGINEERS}

HANFDRD

\section{DESIGN ANALYSIS}

client WHC

subject C Farm Electrical Heat.Tracing Systems

Design

Location $200 \mathrm{E}$, C Farm
Calc. No. W320-31-014

Revision 0

Page No. 5 of 6

wo/Job No. W-320

Date $9 / 19 / 95$

Checked $9 / 27 / 95$

Revised
By R.H. Graeber

By S.A. Najjar $\leq . N$.

By

7.3.4 Appendix " $\mathrm{C}$ " is provided to confirm the Chemelex "5BTV1" tracer selected is more than adequate. These "unqualified" software calculations were provided by the Raychem vendor. These calculation summaries are only attached as a supplement to the official hand calculations.

7.4 Additionally, the Chemelex heat tracing cable option "CR" was selected for all field installed tracer so as to accomplish the following:

7.4.1 Provide improved mechanical protection and

7.4.2 Provide a ground path for electrical safety/protection.

7.5 Thermal Design Results:

\begin{tabular}{|c|c|c|c|}
\hline $\begin{array}{l}\text { MECH. } \\
\text { SYSTEM } \\
\text { NO. }\end{array}$ & CHEMELEX TRACER CAT. NO & $\begin{array}{l}\text { APPROX. TRACER } \\
\text { FOOTAGE }\end{array}$ & SOURCE \\
\hline 7.1 .1 & 5BTV1 & $35^{\prime}$ & By vendor (O'Brien) \\
\hline 7.1 .2 & 5BTV1 & $35^{\prime}$ & By vendor (0'Brien) \\
\hline 7.1 .3 & 5BTV1 & $110^{\prime}$ & By vendor (O'Brien) \\
\hline 7.1 .4 & 5BTV1-CR & $30^{\prime}$ & By ICF/KH \\
\hline 7.1 .5 & 5BTV1-CR & $20^{\prime}$ & By $\mathrm{ICF} / \mathrm{KH}$ \\
\hline
\end{tabular}

A11 W-320 heat tracing cable is/will be RayChem Chemelex "5BTV1."

Maximum heat tracer length on one branch circuit is a combination of 7.1 .3 plus $7.1 .4=140^{\prime}$ total. Three other branch circuits independently feed $7.1 .1,7.1 .2$ and 7.1 .5 .

\subsection{Electrical Circuit Design}

7.6.1 Heat tracing feeder is supplied power from the process buitding mini-power panel C106-PPl.

a) From the table in calculation section 7.5 , total tracer footage is $=230$ feet.

From Chart 6 on page 14 of reference 6.3 , the maximum heating cable length for a 120 volt, 20 amp circuit and start up temperature of 40 Deg. F. using " $5 B T^{\prime \prime}$ is $(40+0)$

$$
185+\frac{(40-0)}{(50-0)}(270-185)=253 \mathrm{feet}
$$

HNF-2488, Rev. 0

Page A-7 


\section{DESIGN ANALYSIS}

client WHC

subject C Farm Electrical Heat Tracing Systems

Design

Location 200 E, C Farm
Calc. No. W320-31-014

Revision 0

Page No. 6 of 6

wo/sob No. $W-320$

Date $9 / 19 / 95$

checked $9 / 27 / 95$

Revised
By R.H. Graeber By S.A. Najjar S $N$.

By

A 20 amp., single pole circuit breaker is adequate at C106-PP1 to feed all electrical heat tracing at C-106 tank.

b) Provide 2 \#12 AWG, THWN and 1 \#12 gnd. in 3/4" conduit to feed all electrical tracers. Voltage drop is not a concern. Distance from C106 - PPl to the heat trace terminal box is approximately $15^{\prime}$. Distance from the heat trace terminal box to the farthest away "power connection kit" is approximateiy $25^{\prime}$.

c) 253 feet $X 5.6$ watts $/$ foot $=1400$. watts is the maximum "5BTV" tracer load a 20 amp., single pole circuit breaker can service.

7.6.2 Branch Circuits: The single heat trace feeder will feed four branch circuits. For segregation, each branch circuit will be fused.

a) From 7.5 , the largest (longest) heat trace branch circuit wi11 involve 140 feet of tracer.

140 feet $\times 5.6$ watts $/$ foot $=784$ watts

784 watts at 120 VAC, 1-phase $=6.5$ amp, indicates the fuse size should be no less than 7 amps - use a 10 amp fuse!

Use 10 amp. fuses for the other three branch circuits.

b) Provide 2 \#12 AWG, THWN and 1 \#12 gnd. in 3/4" conduit or flex conduit for each of the branch circuits.

\subsection{Conclusions}

8.1 A11 W-320 electrical heat tracing is located at the C-106 tank.

8.2 All W-320 electrical heat tracing cable is properly sized to provide freeze protection.

8.3 All electrical heat tracing related electrical circuits and protective devices are properly sized.

8:4 All related wire runs and conduits are properly sized. 


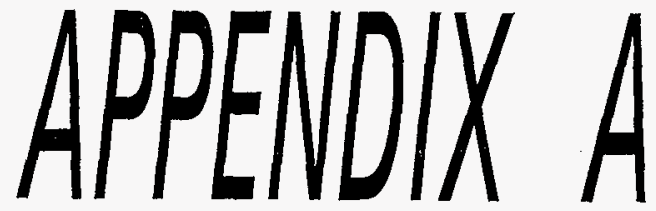

16 PAGES

HNF-2488, Rev. 0

Page A-9 
AN ENGINEERED, PREINSULATED TUBING BUNDLE SYSTEM FROM O'BRIEN CORPORATION
Solves the problems of: Freezing Dew point Component drop-out Viscosity Personnel protection

Freezing, dew point, component dropout and viscosity control are major considerations in instrument and small diameter process lines. A properly designed and selected pretraced tubing bundle offers an effective solution to these problems.

\section{The economical choice to field fabrication}

Maintenance free TRACEPAK not only saves money and time during the installation process, but it ensures consistent, repeatable performance. Field fabrication requires a pipe fitter to lay out, measure, cut, dress, bend and install the tubing. Next the tracer (steam or electric) has to be installed and insulation put on the tubing. Finally, a weatherproof covering needs to be applied over the insulation. Clearly the economics of the TRACEPAK system versus field fabrication are significant.
Provides predictable and repeatable performance

O'Brien Corporation, long recognized as the leader in providing reliable instrumentation protection, has simplified installation while offering predictable operation. TRACEPAK tube bundles are prefabricated, pre-engineered and preinsulated assemblies.

Installation is simplified by the unique parallel configuration, in which process and tracer lines are always parallel inside the bundle. The bundle is much easier to bend during field routing and hookup because all tubes bend together and not against one another.

\section{Connections are easy because tubing stays round and is not work hardened}

TRACEPAK's configuration allows the fubing to stay round and malleable when used in conjunction with compression and flare fittings. The installation of process and instrument connections requires only a simple, one-plane offset bend to engage tubing and fittings.

\section{Can be installed at temperatures as low as $-40^{\circ} \mathrm{F}\left(-40^{\circ} \mathrm{C}\right)$}

O'Brien Corporation utilizes the highest quality materials. The tough elastomeric jacket contains no halogens, eliminating the possibility of chlorides from the jacket causing stress corrosion in stainless steel tubing. This jacket has excellent abrasion and chemical resistance along with a wide, usable temperature range. TRACEPAK can be installed in temperatures as low as $-40^{\circ} \mathrm{F}$.

\section{Types of traced lines}

There are three common types of pretraced lines:

Single preinsulated line, TPS, primarily for steam supply and condensate return.

Steam traced lines, TPL \& TPH, for freeze protection and temperature maintenance.

- Electric traced lines, TPE, for freeze protection and maintenance of temperature.
HNF-2488, Rev. 0

Page A-10 


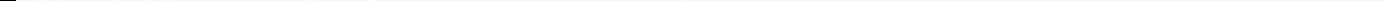


A preinsulated tubing bundle with light steam tracing

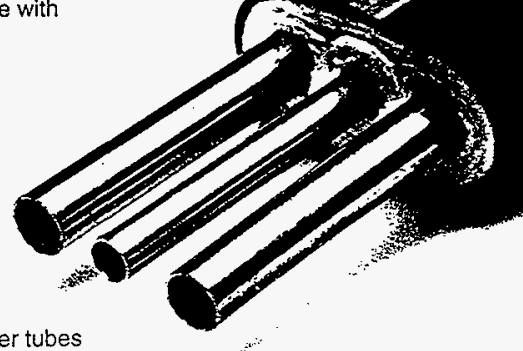

The process tubes and tracer tubes are individually wrapped with insulation to purposely reduce heat transfer.

TPL can maintain temperatures between $50^{\circ} \mathrm{F}\left(10^{\circ} \mathrm{C}\right)$ and $200^{\circ} \mathrm{F}$ $\left(93^{\circ} \mathrm{C}\right)$. It provides a more constant tube temperature over a longer length than heavy traced designs.

It is suited for small diameter process lines such as those used for sampling and additives.

TPL is recommended for freeze protection of instrument impulse lines as well as the process lines for analyzers.
Model Number

Product Family

TPL1-Preinsulated Light Steam Traced Single Process Tube

TPL2-Preinsulated Light Steam Traced Dual Process Tubes

Process Tube

A2 $1 / 4^{\prime} \times 0.035$ wall welded 316 ss

A3 3/8" $\times 0.035$ wall welded 316ss

A4 $1 / 2^{*} \times 0.035$ wall welded 316 ss

F1 $1 / 8^{n} \times 0.035$ wall seamless $316 \mathrm{ss}$

F2 $1 / 4^{*} \times 0.035$ wall seamless 316 ss

F3 3/8" $\times 0.035$ wall seamless 316 ss

B4 $1 / 2 * \times 0.049$ wall seamless $316 s 5$

J2 $1 / 4^{\prime \prime} \times 0.030$ wall copper

C3 $3 / 8^{*} \times 0.032$ wall copper

D4 $1 / 2^{\prime \prime} \times 0.035$ wall copper

G2 $1 / 4^{*}$ OD $\times 0.030$ wall PFA Teflon*

G3 3/8" OD $\times 0.030$ wall PFA Teflon

H4 1/2" OD $\times 0.062$ wall PFA Teflon

MA6, $8,10,12 \cdot 6,8,10$ or $12 \mathrm{~mm}$ OD $\times 1 \mathrm{~mm}$ wall welded 31655
MF6, $8,10,12 \cdot 6,8,10$ or $12 \mathrm{~mm}$ OD $\times 1 \mathrm{~mm}$ wall seamless 316 ss

MD6, $8,10,12 \cdot 6,8,10$ or $12 \mathrm{~mm}$ OD $\times 1 \mathrm{~mm}$ wall copper

MG6, 8, 10, 12-6, 8,10 or $12 \mathrm{~mm}$ OD $\times 1 \mathrm{~mm}$ wall PFA

Tracer

A2 $1 / 4^{*} \times 0.035$ wall welded $316 s s$

A3 $3 / 8^{n} \times 0.035$ wall welded $316 s s$

A4 $1 / 2^{\prime \prime} \times 0.035$ wall welded 316 ss

F2 $1 / 4^{*} \times 0.035$ wall seamless $3165 s$

F3 $3 / 8^{\prime \prime} \times 0.035$ wall seamless 316 ss

B4 $1 / 2^{*} \times 0.049$ wall seamless $316 s$

$\mathrm{J} 2 \mathrm{t} / 4^{*} \times 0.030$ wall copper

C3 $3 / 8^{n} \times 0.032$ wall copper

D4 1/2" $\times 0.035$ wall copper

MAG, $8,10,12-6,8,10$ or $12 \mathrm{~mm}$ OD $\times 1 \mathrm{~mm}$ wall welded 316 ss

MF6, 8, 10, $12-6,8,10$, or $12 \mathrm{~mm}$ OD $\times 1 \mathrm{~mm}$ wall seamless $316 \mathrm{ss}$

MD6, $8,10,12 \cdot 6,8,10$ or $12 \mathrm{~mm}$ OD $\times 1 \mathrm{~mm}$ wall copper

Example:

TPL.2-A4-C3

Two $1 / 2^{*} \times 0.035$ wall 316 SS welded process lines with a $3 / 8^{\prime \prime} \times 0.032$ wall copper tracer.

For specific intomation regarding each of these products, consult individual specilication sheets.
Dimensions

$$
\text { NOMINAL }
$$
LB/FT (KG/M)

TPL1- One 3/8" Process with 3/8" Tracer TPL1- One 1/2" Process with 3/8" Tracer TPL1. One $1 / 2$ " Process with $1 / 2^{\prime \prime}$ Tracer TPL2- Two 3/8" Process with 3/8" Tracer TPL2- Two $1 / 2^{\prime \prime}$ Process with 3/8" Tracer TPL2- Two 1/2" Process with 1/2" Tracer

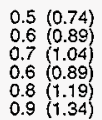

$$
\begin{gathered}
\text { NOMINAL } \\
\text { DIMENSIONS - IN } \\
\text { A } \\
B
\end{gathered}
$$

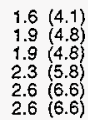

\section{$1.1(2.8)$}

$1.2(3.0)$

$1.2(3.0)$

$1.2(3.0)$

$1.3(3.3)$

$1.3(3.3)$

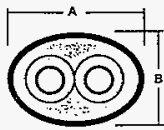

TPL1

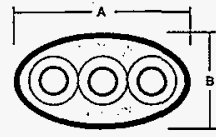

TPL2

TWO 1/2" PROCESS LINES WITH 1/2" TRACER TYPICAL PERFORMANCE

RUN LENGTH - $M$

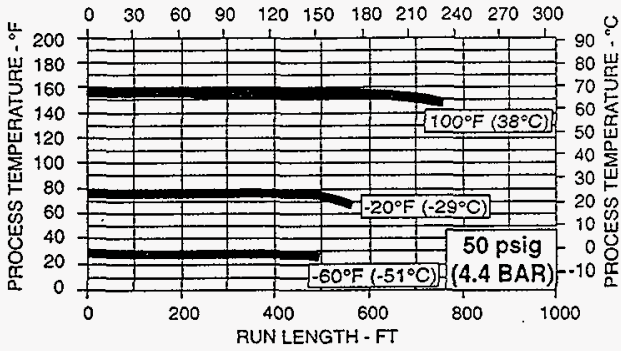

RUN LENGTH - $M$

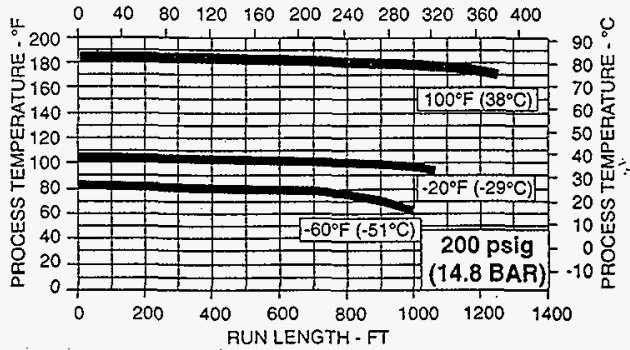




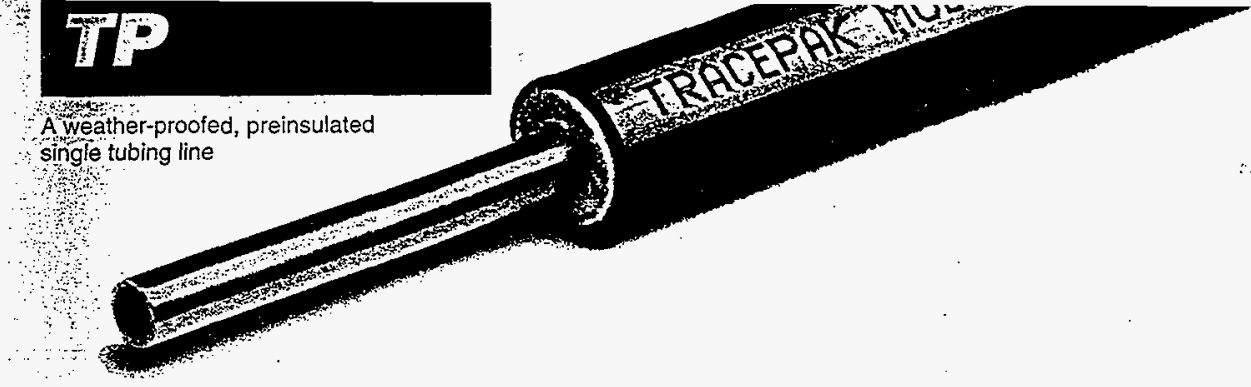

TPS is designed specifically for liquid and gas transport lines where heat loss and personnel protection is important. TPS offers an inexpensive alternative to field insulation and weatherproofing of small lines.<smiles>[131I-]</smiles>

Model Number

Product Family

TPS1-Preinsulated Single Process Tube

Process Tube

A2 $1 / 4^{*} \times 0.035$ wall welded 316 ss

A3 3/8" $\times 0.035$ wall welded 316 ss

A4 $1 / 2 * 0.035$ wall welded 316 ss

F2 $1 / 4^{*} \times 0.035$ wall seamless 316 ss

F3 $3 / 8^{\prime} \times 0.035$ wall seamless 316 ss

B4 $1 / 2^{n} \times 0.049$ wall seamless 316 ss

$\mathrm{J} 21 / 4^{*} \times 0.030$ wall copper

C3 $3 / 8^{*} \times 0.032$ wall copper

D4 $1 / 2^{\prime \prime} \times 0.035$ wall copper

MA6, 8, 10, $12-6,8,10$ or $12 \mathrm{~mm}$ OD $\times 1 \mathrm{~mm}$ wall welded $316 s s$

MF6, $8,10,12-6,8,10$ or $12 \mathrm{~mm}$ OD $\times 1 \mathrm{~mm}$ wall seamiess $316 \mathrm{ss}$

$M D 6,8,10,12 \cdot 6,8,10$ or $12 \mathrm{~mm}$ OD $\times 1 \mathrm{~mm}$ wall copper
Example:

TPS1-C3

One preinsulated $3 / 8^{*} \times 0.032$ wall copper process line.

For specilis informstion regarding each of these products, consur individual specification sheets.

\section{Dimensions}

TPS1- One 1/4" Process Line TPS1- One 3/8" Process Line TPS1- One 1/2" Process Line

\section{NOMINAL \\ WT. \\ LB/FT (KG/M)}

$0.2(0.30)$

$0.3(0.45)$

$0.4(0.60)$
NOMNAL DIMENSIONS $A \cdot I N(C M)$

$1.0(2.5)$

$1.1(2.8)$

$1.2(3.0)$

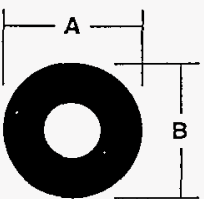

TPS1
3/8" TUBE

Ambient Temperature.${ }^{\circ} \mathrm{C}$

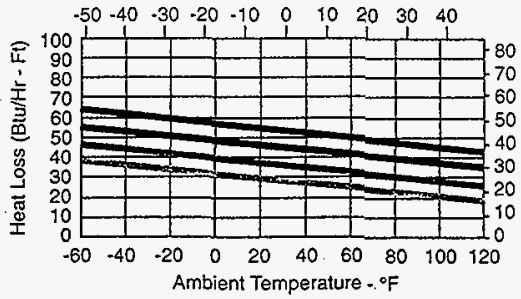

200 psig (14.8 BAR) steam $388^{\circ} \mathrm{F}\left(198^{\circ} \mathrm{C}\right)$

125 psig $(9.6 \mathrm{BAR})$ steam $353^{\circ} \mathrm{F}\left(178^{\circ} \mathrm{C}\right)$

50 psig (4.4 BAR) steam $299^{\circ} \mathrm{F}\left(148^{\circ} \mathrm{C}\right)$

$15 \mathrm{psig}(2.0 \mathrm{BAR})$ steam $250^{\circ} \mathrm{F}\left(121^{\circ} \mathrm{C}\right)$
Ambient Temperature $-{ }^{\circ} \mathrm{C}$

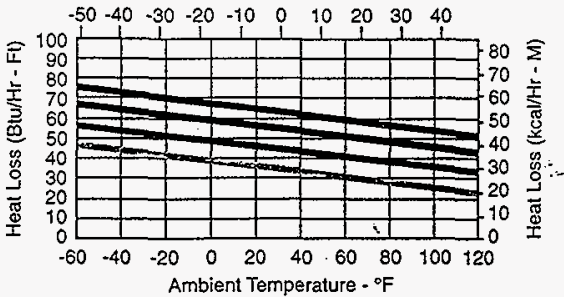

HNF-2488, Rev. 0

Page A-14 


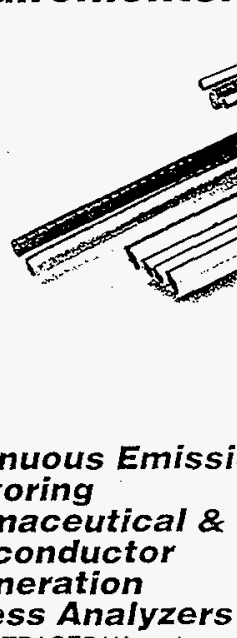

Continuous Emissions Monitoring

Pharmaceutical \&

Semiconductor

\section{Cogeneration}

\section{Process Analyzers}

Standard TRACEPAK, pretraced and preinsulated tubing bundles are designed to solve your application problems. For other requirements, O'Brien will design and manufacture the appropriate tubing bundle.

For example, some application requirements are best met by adding insulation rather than increasing the wattage or steam pressure.

\section{Withstand.High Intermittent Process Temperatures}

By using insulation to buffer the standard self limiting tracer from the process tube, we can increase the maximum process exposure temperature limit and still provide freeze protection.

\section{Communication Wires}

Communication. monitor and thermocouple wires may be added to the bundle as specified by the customer.

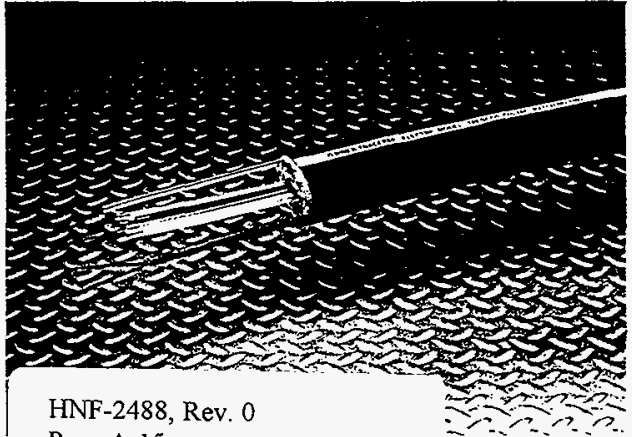

Page A-15

\section{Maintain}

\section{High Process} Temperatures

Specialty tracers can be used to provide temperature maintenance up to and beyond $660^{\circ} \mathrm{F}\left(350^{\circ} \mathrm{C}\right)$. Depending on the specific tracer used, this product can also withstand process temperatures of $1000^{\circ} \mathrm{F}\left(538^{\circ} \mathrm{C}\right)$

\section{Meet Tubing Specifications}

TRACEPAK can be manufactured with tubing that conforms to your requirements including exotic alloys, uncommon materials, odd sizes and coaxial tubing. For high purity applications, we can also supply tubing that has been cleaned for oxygen service and/or electropolished.

\section{Sample Transport Bundles for Continuous Emissions Monitoring}

Bundies with multiple process fubes, calibration gas supply tubes, tracers, communication wires and power wiring are designed to be in compliance with code. The sample transport bundle is developed to meet the needs of the application. 


\section{SEALING THE BUNDLE}

Although TRACEPAK products use a non-hygroscopic, non-wicking insulation, all bundle ends must be sealed to prevent any possible moisture contamination.

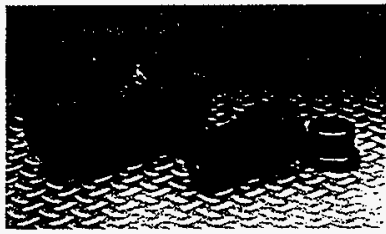

\section{TPKES - Heat Shrink Entry Seal}

The heat-shrinkable entry seal provides a waterproof fitting where TRACEPAK enters an enclosure. They can be added to parting line or surface mounted plates on VIPAK enclosures or any enclosure with up to a $1 / 2 " 13 \mathrm{~mm})$ wall. The thermally stabilized, modified polyolefin entry seal consists of an O-ring assembly that seals at the enclosure and a heatshrinkable nose that seals to the TRACEPAK bundle.

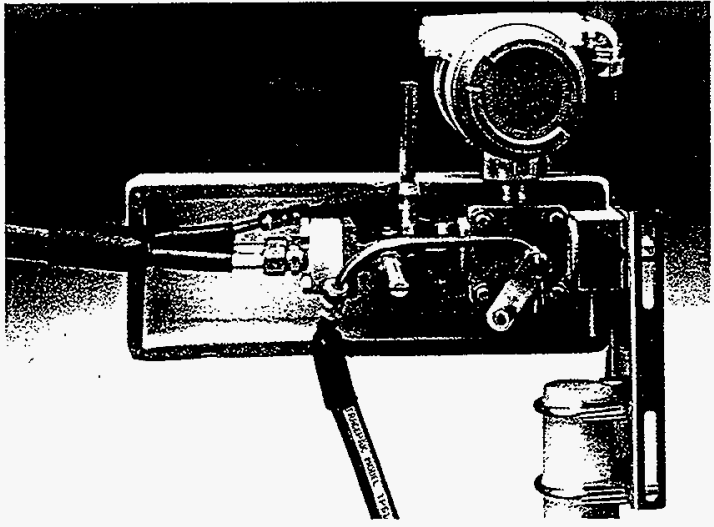

TPKHS - Heat Shrink Boots The heat-shrinkable boots provide a weatherproof end seal for TRACEPAK tubing bundles. They are made of thermally stabilized, modified polyolefin. Using a heat shrink end seal boot is recommended for all exposed ends. This installation will provide the best weather seal protection. The silicone end seal alone may be used to seal the end of the bundle inside of a VIPAK enclosure.

HNF-2488, Rev. 0

Page A-16

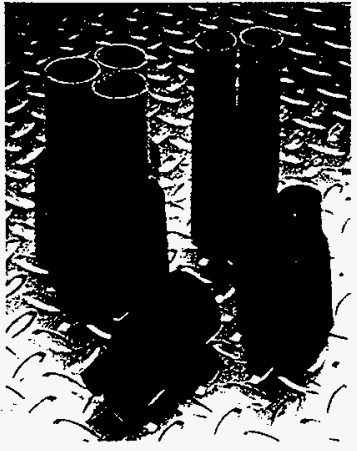




\section{TPKJP - Jacket Patch}

The jacket patch kits are used to seal a splice in a bundle or to extend the insulation and weatherproof jacket should the bundle be cut back too far during installation. They are used as a repair patch for any incidental field damage to bundles. The jacket patch kit is required with the optional line temperature sensing thermostat. Each kit contains thermal insulation, fiberglass tape and a self-sealing patch.

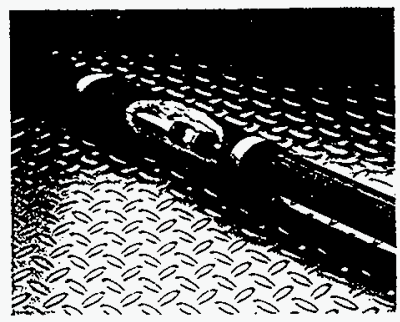

TPKSK - Silicone Sealant

This option is used to seal both ends of the tubing bundle from moisture. It is a black silicone RTV sealant. Cure time is approximately 24 hours at $77^{\circ} \mathrm{F}\left(25^{\circ} \mathrm{C}\right)$. Service temperature ranges from $-50^{\circ} \mathrm{F}\left(-45^{\circ} \mathrm{C}\right)$ to $400^{\circ} \mathrm{F}$ $\left(205^{\circ} \mathrm{C}\right)$. TPKSK offers excellent resistance to weather, oil and many chemicals.
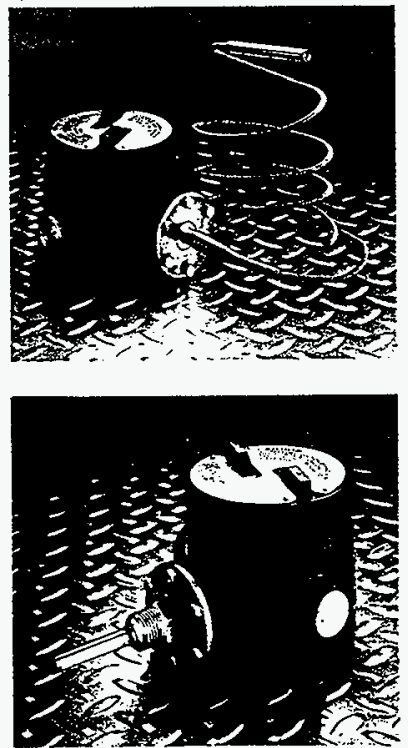

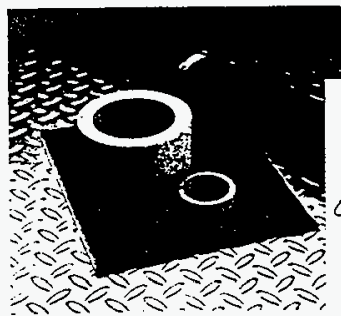

Heat Entry Mode

\section{THERMOSTATS}

When used with electrically traced tubing bundles, optional thermostats are used to control the temperature of the process tube or to turn on the heater at a specified ambient temperature.
HNF-2488, Rev. 0

Page A-17

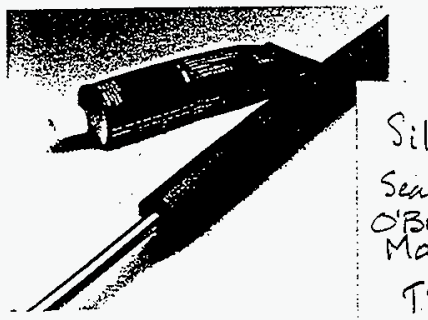

\section{Line Sensing}

Line sensing thermostats directly control the temperature of the process tubes. They have an adjustable set point of $75^{\circ} \mathrm{F}\left(24^{\circ} \mathrm{C}\right)$ to $200^{\circ} \mathrm{F}\left(94^{\circ} \mathrm{C}\right)$. The capillary and bulb are stainless steel. The SPDT switch is rated for $15 \mathrm{~A}$ at $120 / 240$ VAC. It is CSA certified and UL listed for Class I, Division 1 and 2, Groups B, C and D.

\section{Ambient Sensing}

This ambient sensing thermostat has an adjustable set point from $0^{\circ} \mathrm{F}$ $\left(-18^{\circ} \mathrm{C}\right)$ to $100^{\circ} \mathrm{F}\left(38^{\circ} \mathrm{C}\right)$. The SPDT switch is rated for 15A at 120/240VAC. It is CSA certified and UL listed for Class I, Division 1 and 2, Groups B, C and D.

Note: received may ditier. 


\section{POWER}

\section{CONNECTION AND}

TERMINATION KITS

These components are used to connect the electric tracer to the power source and terminate the non-powered ends in an approved manner.

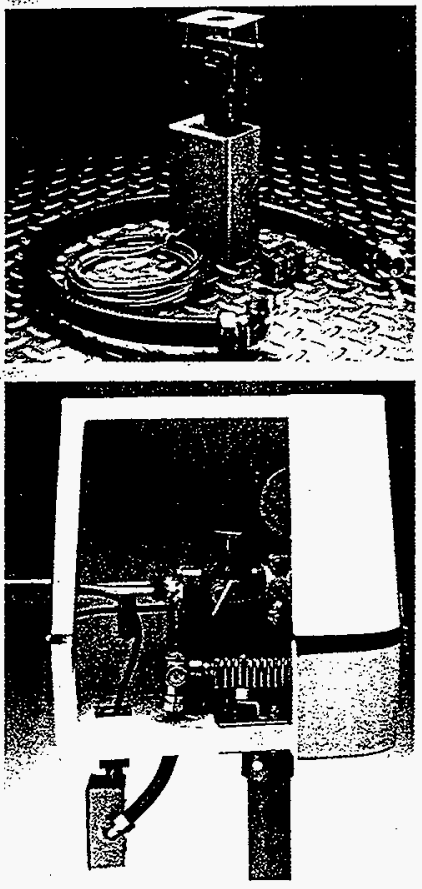

\section{LPD2}

\section{Combination Power Connection Kit}

This power connection kit is used with $E$ and $L E$ series electric heaters. It incorporates FM approved and CSA certified components to provide a power connection assembly for the TPE tracer and the enclosure heater. When used with a VIPAK enclosure, the LPD2 provides the convenience of an external junction box with a $3 / 4^{\prime \prime}$ NPT connection.

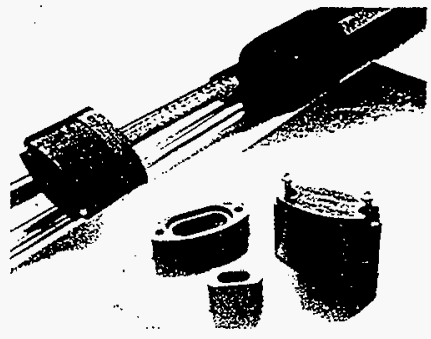

PMKG.LE and PMKG-LE.CSA

\section{End Fitting}

These end fitings are FM approved or CSA certified for XTV and BTV

self-regulating tracer. They are NEMA $4 \mathrm{X}$ fittings and are used to terminate the non-powered end of the tracer. With a CENELEC accepted electric tracer the end fitting must be approved by the country of use.

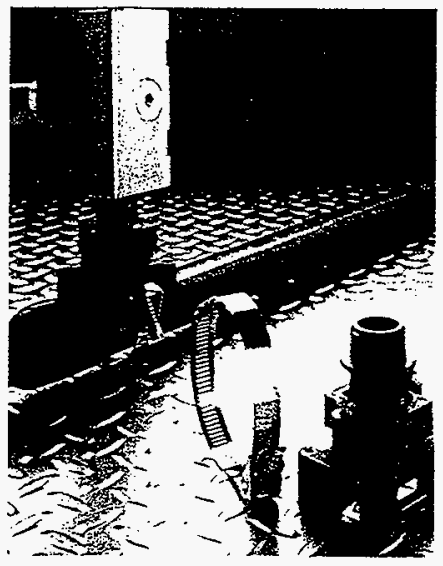

PMKG-LP and PMKG-PC-CSA Power Connection Fittings These fittings are used to power the tracer when the bundle is used by itself. They are also used when the bundle is powered from the end opposite the enclosure. They are FM approved or CSA certified for XTV or BTV self-regulating tracer. With a CENELEC accepted electric tracer the power fitting must be approved by the country of use.
HNF-2488, Rev. 0

Page A-18 
TPC1 and PMKG.Y Combination Power Connection Kits

The TPC1 kit may be ordered alone or as part of a Div. 1, E or LE series heater. It is CSA certified for Division 1 applications.
The PMKG-Y kit is ordered as part of a Div. 2, LE series heater. It is FM approved for Division 2 applications.

These kits are used with $E$ and $L E$ series heaters to power the tracer from the heater junction box in the instrument enclosure. If an outs junction box is not required, the provide the most economical an practical method of supplying $p r$ to the TRACEPAK tracer.
Posse
Kit
Cinstal

Proce Mriod PMK

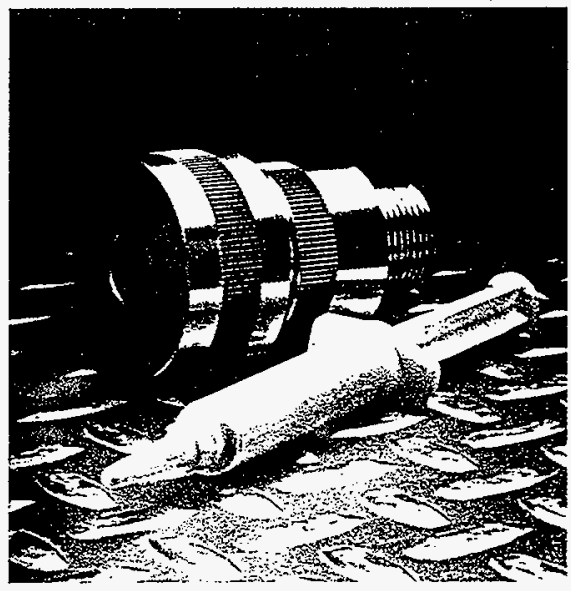

TPC1

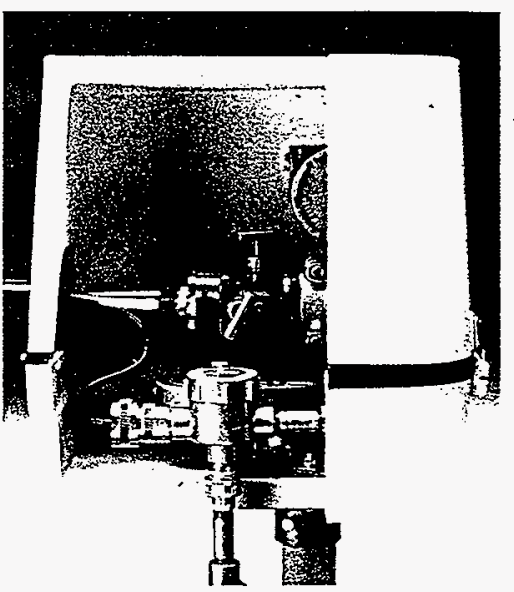

Splia
Con
$k$
Cinstal
Euclos
Koyche
Mose
PMk
Tee
Cont
Ki
Rayche
Mode
PMK.
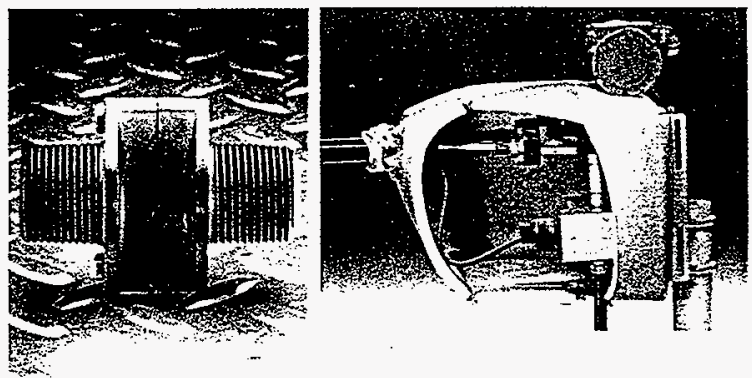

PMKG-Y

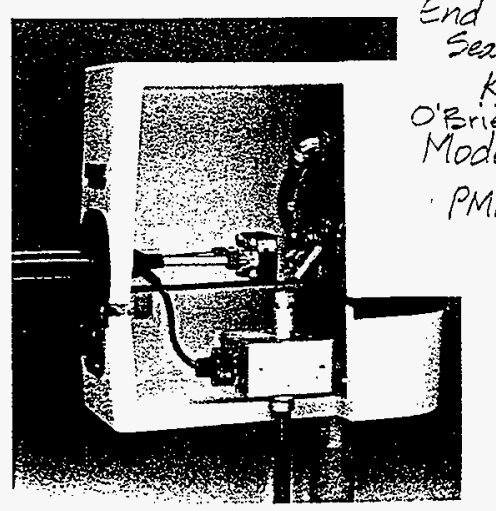

HNF-2488, Rev. 0

Page A-19 
A preinsulated tubing bundle with self regulating electric tracing
HNF-2488, Rev. 0

Page A-20
TPE is designed to maintain freeze protection, close temperature tolerances or viscosity control. It provides an excellent means of maintaining very long, continuous lengths of impulse lines and piping at consistent temperatures end-toend. TPE should be chosen when steam is not available or when the steam supply could be interrupted such as during shutdowns.

Use TPE if the allowable temperature ranges from $50^{\circ} \mathrm{F}$ $\left(10^{\circ} \mathrm{C}\right)$ to $250^{\circ} \mathrm{F}\left(121^{\circ} \mathrm{C}\right)$. Because it is self regulating, this system will lower its heat output as the material gets warmer. When close temperature control is necessary, TPE can be utilized with an optional line sensing thermostat.
TPE offers a choice of two standard tracers. A high temperature tracer (XTV) is capable of maintaining temperatures of up to $250^{\circ} \mathrm{F}\left(121^{\circ} \mathrm{C}\right)$ and withstanding blowdown temperatures of $420^{\circ} \mathrm{F}\left(215^{\circ} \mathrm{C}\right)$. A low temperature tracer (BTV) will maintain temperatures up to $150^{\circ} \mathrm{F}$. $\left(65^{\circ} \mathrm{C}\right)$ and withstand process temperatures of up to $185^{\circ} \mathrm{F}\left(85^{\circ} \mathrm{C}\right)$.

Other designs are available to maintain temperatures up to $660^{\circ} \mathrm{F}$ $\left(350^{\circ} \mathrm{C}\right)$ and withstand $1000^{\circ} \mathrm{F}$ $\left(538^{\circ} \mathrm{C}\right)$ blowdown conditions. Consult factory for specific design.

\section{Electric tracer}

Standard TPE-Self Regulating products utilize Chemelex electric tracers:" They are FM approved and CSA certified for use in hazardous areas when used with the recommended power connection kits.
CENELEC accepted approvals for Zone 1 and 2 heaters with T3 temperature limits are available.

The high temperature, Self Regulating XTV Tracer:

1. Withstands $420^{\circ} \mathrm{F}\left(215^{\circ} \mathrm{C}\right)$ intermittent blowdown temperatures.

2. Can maintain temperatures up to $250^{\circ} \mathrm{F}\left(121^{\circ} \mathrm{C}\right)$.

The low temperature Self Regulating BTV Tracer:

1. Withstands up to $185^{\circ} \mathrm{F}$ $\left(85^{\circ} \mathrm{C}\right)$ blowdown temperatures.

2. Can maintain temperatures up to $150^{\circ} \mathrm{F}\left(65^{\circ} \mathrm{C}\right)$.

The choice between XTV and BTV must be made based on the desired performance and the conditions of the application. XTV and BTV are backed by a 10 year performance guarantee.
Dimensions

TPE1- One $1 / 4$ " Process Tubes

TPE1- One 3/8" Process Tubes

TPE1- One $1 / 2^{\prime \prime}$ Process Tubes

TPE2- Two 1/4" Process Tubes

TPE2- Two 3/8" Process Tubes

TPE2- Two $1 / 2^{4}$ Process Tubes

$$
\begin{gathered}
\text { NOMINAL } \\
\text { WT. } \\
\text { LB/FT (KGM) }
\end{gathered}
$$

$0.3(0.45)$

$0.4(0.60)$

$0.5(0.74)$

$0.4(0.60)$

$0.6(0.89)$

$0.8(1.19)$

\section{NOMINAL MENSIONS - IN (CM)} A.

$1.1(2.8)$

$1.3(3.3)$

$1.4(3.6)$

$1.3(3.3)$

$1.5(3.8)$

$1.7(4.3)$
$1.0(2.5)$

$1.0(2.5)$

$1.1(2.8)$

$1.1(2.8)$

$1.2(3.0)$

$1.4(3.6)$

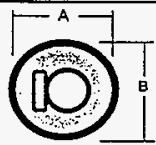

TPE1

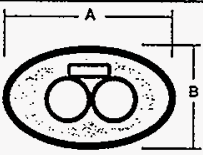

TPE2
TPE1 - ONE $1 / 2$ " PROCESS

LINE WITH XTV TRACER

Ambient Temperature $-{ }^{\circ} \mathrm{C}$

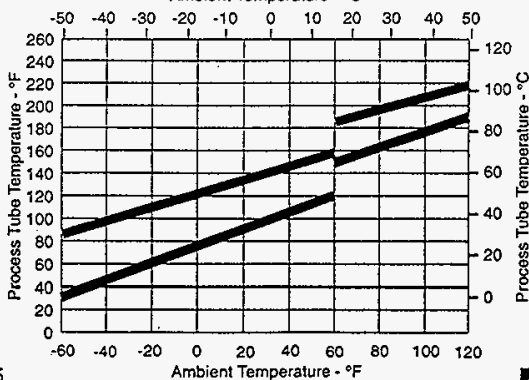

TPE2 - TWO 1/2" PROCESS LINES WITH XTV TRACER

Ambient Temperature - ${ }^{\circ} \mathrm{C}$

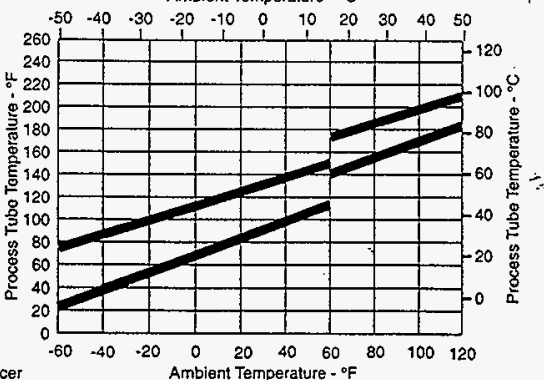

Chemelex is a registered trademark of Raychem Corporation. 
HNF-2488, Rev. 0

Page A-21

Model Number

Product Family

- TPE1-Preinsulated Electrically Traced Single Process Tube

TPE2-Preinsulated Electrically Traced. Dual Process Tubes

Process Tube

A2 1/4" $\times 0.035$ wall welded 316 ss

A3 3/8" $\times 0.035$ wall welded $316 \mathrm{ss}$

.- A4 1/2" $\times 0.035$ wall weided $316 s s$

F1 $1 / 8^{\prime \prime} \times 0.035$ wall seamless 316 ss

F2 $1 / 4^{\prime \prime} \times 0.035$ wall seamless 316 ss

F3 3/8 $\times 0.035$ wall seamiess 316 ss

-B4 1/2" $\times 0.049$ wall seamless 316 ss

J2 $1 / 4^{*} \times 0.030$ wall copper

C3 3/8' $\times 0.032$ wall copper

D4 $1 / 2 * \times 0.035$ wall copper

G2 $1 / 4^{\prime \prime}$ OD $\times 0.030$ wall PFA Teilon

G3 3/8" OD $\times 0.030$ wall PFA Teflon

G2 $1 / 4^{\prime \prime}$ OD $\times 0.030$ wall PFA Teflon ${ }^{*}$

G3 3/8" OD $\times 0.030$ wall PFA Telion

H4 1/2" OD $\times 0.062$ wall PFA Tefion

MA6, $8,10,12-6,8,10$ or $12 \mathrm{~mm}$ OD $\times 1 \mathrm{~mm}$ wall welded $316 \mathrm{ss}$

MF6, $8,10,12 \cdot 6,8,10$ or $12 \mathrm{~mm}$ OD $\times 1 \mathrm{~mm}$ wall seamless 316 ss

MD6, $8,10,12-6,8,10$ or $12 \mathrm{~mm}$ OD $\times 1 \mathrm{~mm}$ wall copper

MG6, 8, 10,12-6, 8, 10 or $12 \mathrm{~mm}$ OD $\times 1 \mathrm{~mm}$ wall PFA
Tracer

XTV

B5 - 5 watt per foot self-regulating heater $650^{\circ} \mathrm{F}\left(10^{\circ} \mathrm{C}\right), 120$ vac

B10-10 watt per foot self-regulating heater (9) $50^{\circ} \mathrm{F}\left(10^{\circ} \mathrm{C}\right), 120$ vac

N5 - 5 watt per foot self-regulating heater Q5 $0^{\circ} \mathrm{F}\left(10^{\circ} \mathrm{C}\right), 240$ vac

N10 .10 watt per foot self-regulating heater (a) $50^{\circ} \mathrm{F}\left(10^{\circ} \mathrm{C}\right), 240 \mathrm{vac}$

MN4, 12.4 or 12 watt per foot $\$ 10^{\circ} \mathrm{C}$ 220 vac

BTV

- J5 - 5 watt per foot self-regulating heater Q50 $0^{\circ} \mathrm{F}\left(10^{\circ} \mathrm{C}\right), 120$ vac

J8 - 8 watt per foot self-regulating heater Q50 $50^{\circ} \mathrm{F}\left(10^{\circ} \mathrm{C}\right), 120$ vac

P5 - 5 watt per foot self-regulating heater (950\% $\left(10^{\circ} \mathrm{C}\right), 240$ vac

PQ - 8 watt per foot self-regulating heater @ $50^{\circ} \mathrm{F}\left(10^{\circ} \mathrm{C}\right), 240 \mathrm{vaC}$

MP5, 8 - 5 or 8 watt per foot (a) 10 $\mathrm{C}, 220 \mathrm{vac}$

All tracers have a tinned copper shield and fluoropolymer outer jacket.

FM approved for Class I, II, III Div. 2

Gr. B, C, D, F, G.

CSA Cerified for Class I, II Div. 1, 2

Gr. A, B, C, D, E, F, G.

CSA Certified for Class III Div. 2

MN and MP designateo tracers are approved

by CENELEC accepted agencies.
Pre

Tubi

elestr

$1 / 21100$

Wall,

SST

Typical Performanc

Each graph shows typical

MODE TPE

performance splitting summer/winter ambients. Each line is separated at $60^{\circ} \mathrm{F}\left(16^{\circ} \mathrm{C}\right)$ to designate the

seasonal differences.

Winter ambients, below $60^{\circ} \mathrm{F}$ $\left(16^{\circ} \mathrm{C}\right)$, assume a $25 \mathrm{mph}(40 \mathrm{Km} / \mathrm{H})$ wind and summer ambients, above $60^{\circ} \mathrm{F}\left(16^{\circ} \mathrm{C}\right)$, assume a $10 \mathrm{mph}(16$ $\mathrm{Km} / \mathrm{H}$ ) wind. For freeze protection, use $50^{\circ} \mathrm{F}\left(10^{\circ} \mathrm{C}\right)$ as the minimum allowable process tube temperature. This will provide a sufficient factor of safety.

Example:

TPE2-A4-B5

Two $1 / 2^{\prime \prime} \times 0.035$ wall 316 SS welded process lines with a 5 watt/foot tracer.

For specific intormation recarding each of these products, consult inoividual specification sheets.
TPE - ONE 1/2" PROCESS

LINE WITH BTV TRACER

Ambient Temperature - ${ }^{\circ} \mathrm{C}$

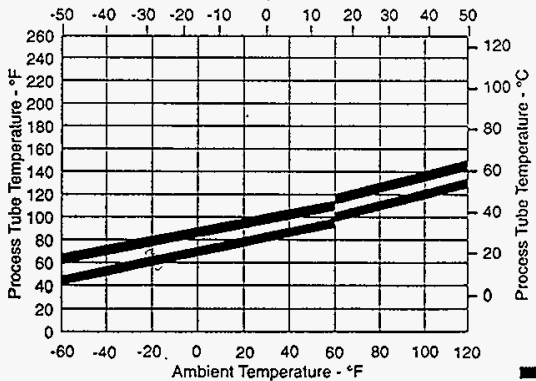

8 watlft Tracer 5 wattht Trace
TPE2 - TWO 1/2" PROCESS

LINES WITH BTV TRACER

Ambient Temperature ${ }^{\circ} \mathrm{C}$

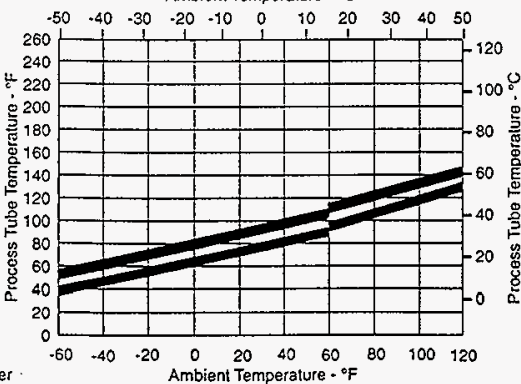

6 
Page A-22

A preinsulated tubing bundle with heavy steam tracing

HNF-2488, Rev. 0
TPH is recommended for use on impulse lines for instrumentation, process lines for analyzers, sampling, additives and other small process lines where higher temperature maintenance is necessary. It is especially important for viscosity control.

Heavy tracing keeps the process tubing in direct contact with the tracer and maintains higher process temperatures.

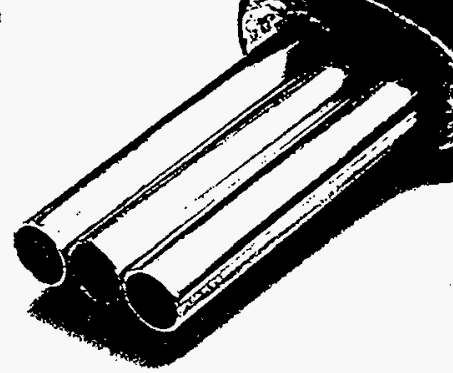

Model Number

Product Family

TPH1-Preinsulated Heavy Steam Traced Single Process Tube

TPH2-Preinsulated Heavy Steam Traced Dual Process Tubes

\section{Process Tube}

A2 $1 / 4^{*} \times 0.035$ wall weldeo 316 ss

A3 3/8* $\times 0.035$ wall welded 316 ss

A4 $1 / 2^{n} \times 0.035$ wall welded $316 s s$

F1 $1 / 8^{n} \times 0.035$ wall seamless $316 \mathrm{ss}$

F2 $1 / 4^{*} \times 0.035$ wall seamless 3165 s

F3 $3 / 8^{*} \times 0.035$ wall seamless 316 ss

B4 $1 / 2^{\prime \prime} \times 0.049$ wall seamless 31655

$\mathrm{J} 21 / 4^{\prime \prime} \times 0.030$ wall copper

C3 3/8* $\times 0.032$ wall copper

D4 $1 / 2 \times 0.035$ wall copper

G2 $1 / 4^{*}$ OD $\times 0.030$ wall PFA Tefion

G3 3/8" OD $\times 0.030$ wall PFA Teflon

$\mathrm{H} 41 / 2^{\prime} \mathrm{OD} \times 0.062$ wall PFA Teflon

MA6, $8,10,12-6,8,10$ or $12 \mathrm{~mm}$ OD $\times 1 \mathrm{~mm}$ wall welded 316 ss

Dimensions

$$
\begin{gathered}
\text { NOMINAL } \\
\text { WT. } \\
\text { LB/FT (KG/M) }
\end{gathered}
$$

TPH1- One 3/8" Process with 3/8" Tracer $0.5(0.74)$

TPHy- One $1 / 2^{4}$ Process with $3 / 8^{" ~ T r a c e r ~} 0.6(0.89)$

TPH1-One 1/2" Process with 1/2" Tracer 0.7 (1.04

TPH2- Two 3/8" Process with 3/8" Tracer $0.6(0.89)$

TPH2- Two $1 / 2^{\mu}$ Process with $3 / 8^{\prime \prime}$ Tracer 0.7 (1.04)

TPH2- Two 1/2" Process with 1/2" Tracer $0.8(1.19)$

NOMINAL
DIMENSIONS - IN (CM)
A
$\begin{array}{cc}\text { B } \\ 1.5(3.8) & 1.2(3.0) \\ 1.6(4.1) & 1.2(3.0) \\ 1.7(4.3) & 1.2(3.0) \\ 2.0(5.1) & 1.2(3.0) \\ 2.1(5.4) & 1.2(3.0) \\ 2.2(5.6) & 1.2(3.0)\end{array}$

MF6, 8, 10, $12-6,8,10$ or $12 \mathrm{~mm}$ OD $\times 1 \mathrm{~mm}$ wall seamless 316 ss

MD6, $8,10,12-6,8,10$ or $12 \mathrm{~mm}$ OD $\times 1 \mathrm{~mm}$ wall copper

MG6, $8,10,12 \cdot 6,8,10$ or $12 \mathrm{~mm} \mathrm{OD} \times 1 \mathrm{~mm}$ wall PFA

Tracer

A2 $1 / 4^{*} \times 0.035$ wall welded $316 s s$

A3 $3 / 8^{\prime \prime} \times 0.035$ wall welded $316 s 5$

A4 $1 / 2^{\prime \prime} \times 0.035$ wall welded 316 ss

F2 1/4" $\times 0.035$ wall seamless 316 ss,

F3 3/8" $\times 0.035$ wall seamiess 316 ss

B4 $1 / 2^{*} \times 0.049$ wall seamless 316 ss

$\mathrm{J} 21 / 4^{\prime \prime} \times 0.030$ wall copper

C3 $3 / 8^{*} \times 0.032$ wall copper

D4 $1 / 2 * 0.035$ wall copper

MA6, $8,10,12 \cdot 6,8,10$ or $12 \mathrm{~mm}$ OD $\times 1 \mathrm{~mm}$ wall welded 316 ss

MF6, $8,10,12-6,8,10$ or $12 \mathrm{~mm}$ OD $\times 1 \mathrm{~mm}$ wall seamless $316 \mathrm{ss}$

MD6, $8,10,12 \cdot 6,8,10$ or $12 \mathrm{~mm}$ OD $\times 1 \mathrm{~mm}$ wall copper

Example:

TPH2-A4-C3

Two $1 / 2^{*} \times 0.035$ wall 316 SS welded process lines with a $3 / 8^{*} \times 0.032$ wall copper tracer.

For specitic intormation reosrding each of these producis, consult individua! specification sheets.

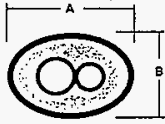

TPH1

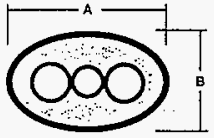

TPH2

TWO $1 / 2 "$ PROCESS LINES WITH ONE 3/8" TRACER TYPICAL PERFORMANCE RUN LENGTH - M

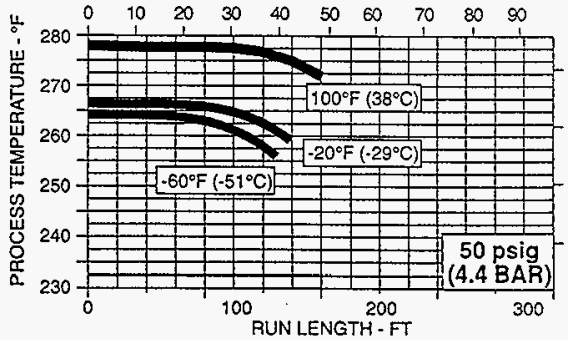

RUN LENGTH - FT

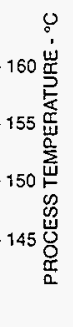

RUN LENGTH - M

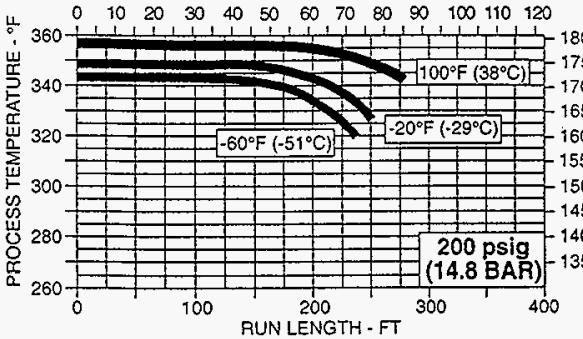




\section{INSTALLATION TOOLS}

TRACEPAK is designed to be installed using standard bending tools. We have designed two special tools that make installation of TRACEPAK tube bundles easier and more compact.

\section{Bundle Bending Tool}

Similar to a common electrical conduit bender, this tool is compact and easy to use. It eliminates the need for larger and heavier benders that have the required 8 " minimum bending radius.

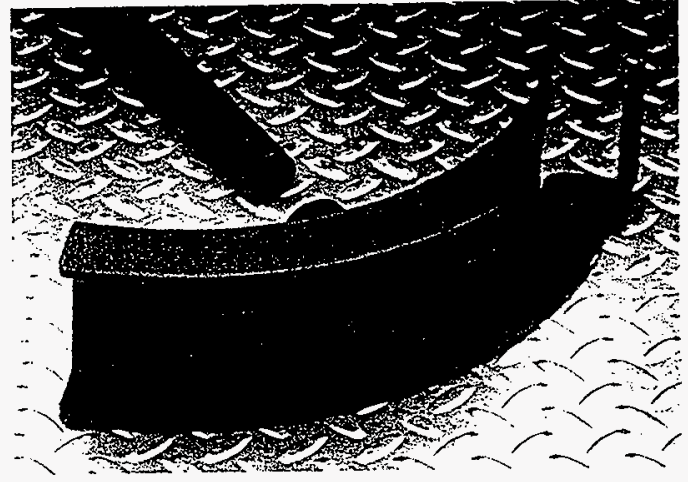

\section{$2 \frac{1}{8}$ "Centerline Tool}

A replacement for the standard tube bender, it brings the process tubes to the correct centerline for connecting to typical transmitters. This tool makes back-to-back bends easier accomplishing the bends in a much shorter distance than possible with a standard tube bender.
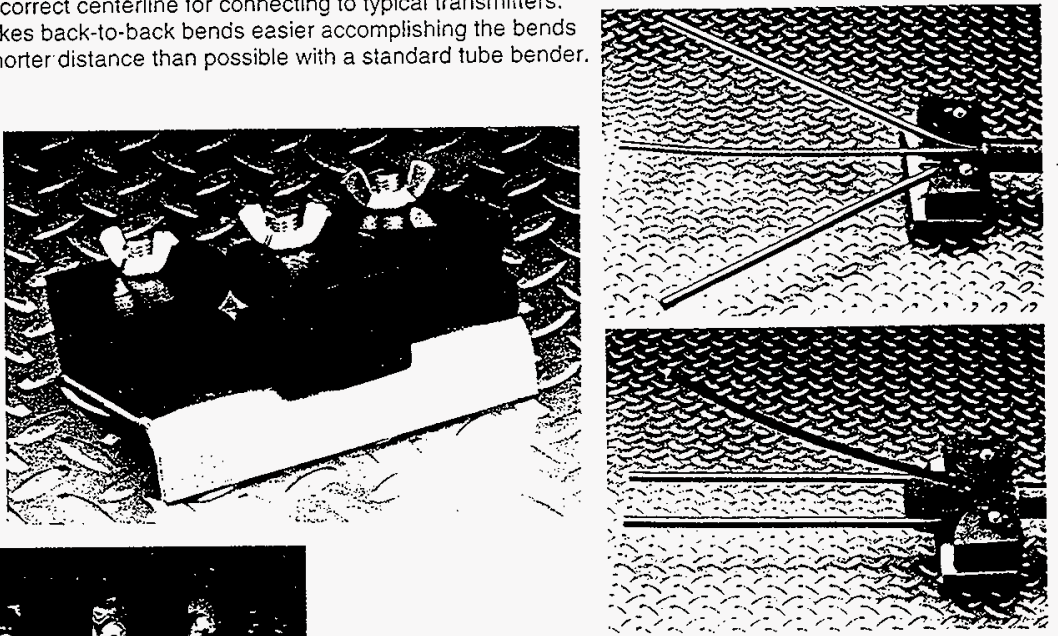

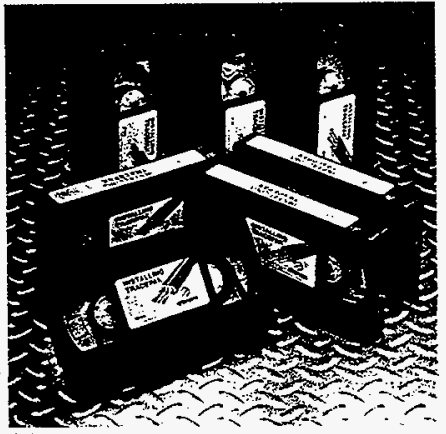

HNF-2488, Rev. 0 Page A-23

\section{Installation Video}

Informative, current information on the installation of TRACEPAK tubing bundies. The video deals with general installation procedures and gives a good overview of the products and accessories available to complement and complete the total 'PAK'age.

(1) 


\section{MATERIAL SPECIFICATIONS}

The following specifications apply to all members of the TRACEPAK family.

JACKET

plastic Polyether Urethane Elastomer

Thermoplastic Polyether Urethane Elastomer

Hydrolytically Stabilized

Halogen Free

Abrasion Resistance

UV Resistant

Low Temperature Flexibility

INSULATION

Fibrous Glass

Water Soluble Chlorides less than $100 \mathrm{ppm}$.

Non-hygroscopic
TUBING

\section{CONSTRUCTION}

AND

OD WALL MATERIAL

ASTM

$1 / 4$ " 0.035 "welded $3165 s \quad$ A-269

$3 / 8^{\circ}, 0.035$ welded 316ss A-269

$1 / 2 " 0.035$ welded $316 s s \quad$ A-269

$1 / 4^{\prime} \quad 0.035$ seamless $3165 \$$ A-269

3/8' $\quad 0.035$ seamless 3165 s A-269

$1 / 2^{*} \quad 0.049$ seamless $316 \mathrm{ss}$ A-269

$1 / 4^{*} \quad 0.030$ copper

3/8. 0.032 copper

$1 / 2$ " 0.035 copper

$1 / 4^{*} \quad 0.030 \quad 1 / 4^{*}$ OD PFA

$3 / 8^{*} \quad 0.030 \quad 3 / 8^{\prime}$ OD PFA

$1 / 2^{*} \quad 0.062 \quad 1 / 2^{\circ}$ OD PFA

$6 \mathrm{~mm} 1 \mathrm{~mm}$ welded $316 \mathrm{ss}$

$8 \mathrm{~mm} 1 \mathrm{~mm}$ welded $316 \mathrm{ss}$

$10 \mathrm{~mm} 1 \mathrm{~mm}$ welded $316 \mathrm{ss}$

A-269

$12 \mathrm{~mm} 1 \mathrm{~mm}$

$6 \mathrm{~mm} 1 \mathrm{~mm}$

welded $316 \mathrm{ss}$

seamless $316 s s$

A-269

A- 269

A.269

A-269

$8 \mathrm{~mm}$ 1mm seamless $316 \mathrm{ss}$ A-269

$10 \mathrm{~mm}$ imm seamiess $316 \mathrm{ss}$ A.269

$12 \mathrm{~mm} 1 \mathrm{~mm}$ seamless $316 \mathrm{ss}$ A-269

$6 \mathrm{~mm}$ I $\mathrm{mm}$ copper

$8 \mathrm{~mm} 1 \mathrm{~mm}$ copper

$10 \mathrm{~mm} 1 \mathrm{~mm}$ copper

$12 \mathrm{~mm} 1 \mathrm{~mm}$ copper

$6 \mathrm{~mm} 1 \mathrm{~mm} 1 / 4^{\prime}$ ODPFA

$8 \mathrm{~mm} 1 \mathrm{~mm} 3 / 8^{\circ}$ OD PFA

$10 \mathrm{~mm} 1 \mathrm{~mm} 1 / 2 *$ OD PFA

$12 \mathrm{~mm} \mathrm{imm} 1 / 2^{\circ}$ OD PFA

Tubing meeting NACE MR-01-75-90 and ASTM A-213-EAW specifications are also stocked. Consult factory for the availability of these as well as other materials and specifications.

\section{TEMPERATURE LIMITS}

Minimum installation temperature $-40^{\circ} \mathrm{F}\left(-40^{\circ} \mathrm{C}\right)$

Maximum jacket surface temperature $140^{\circ} \mathrm{F}\left(60^{\circ} \mathrm{C}\right)$ at ambient temperature of $80^{\circ} \mathrm{F}$ $\left(27^{\circ} \mathrm{C}\right)$ with maximum process or tracer tube temperature.

Maximum process tube temperature

TPH, TPL and TPS $400^{\circ} \mathrm{F}\left(204^{\circ} \mathrm{C}\right)^{\circ}$ TPE

Continuous exposure power on. XTV $250^{\circ} \mathrm{F}\left(121^{\circ} \mathrm{C}\right)^{*}$ BTV $150^{\circ} \mathrm{F}\left(65^{\circ} \mathrm{C}\right)^{*}$

Intermittent exposure power on or off. XTV $420^{\circ} \mathrm{F}\left(215^{\circ} \mathrm{C}\right)^{*}$ BTV $185^{\circ} \mathrm{F}\left(85^{\circ} \mathrm{C}\right)^{*}$

Maximum TPE tracer temperature XTV T-rating T2C, $446^{\circ} \mathrm{F}\left(230^{\circ} \mathrm{C}\right)$ BTV T-rating $T 6,185^{\circ} \mathrm{F}\left(85^{\circ} \mathrm{C}\right)$

-Consult Factory for Higher Temperature Limits.

HNF-2488, Rev. 0

Page A-24 


\section{Customer Service}

Customer service takes on a whole new meaning at O'Brien

Corporation. Our reputation as a customer-oriented problem solver has been long recognized.

O'Brien's customer-oriented approach offers these benefits:

- responsive, knowledgeable personnel

- unparalleled delivery service

- dependable, tested results of all product lines

- in-house stock of hard -to-find materials

\section{0 \& CANZ299 Unparalleled Quality}

Certified to current 1509000 and. CAN Z299 standards. Our adherence to recognized international quality standards provides one of the strongest assurances of product and service quality available.

\section{Total solution}

From Instrument to Process Line: Working together, we can develop installation details. Our total engineering package will réduce field installation costs and provide a dependable solution for your needs.

O'Brien Corporation now provides a próduct for any instailation.

\section{SADDLEPAK HEATPAK VIPAK FLEXPAK TRACEPAK}

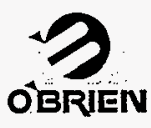

HNF-2488, Rev. 0 


\section{APDENDIX B}

\section{PAGES}

HNF-2488, Rev. 0

Page A-26 


\section{Design Guide for Insulated Pipes and Tubing}

\section{Auto-Trace Heat-Tracing Systems for Orinary and Division 2 areas}
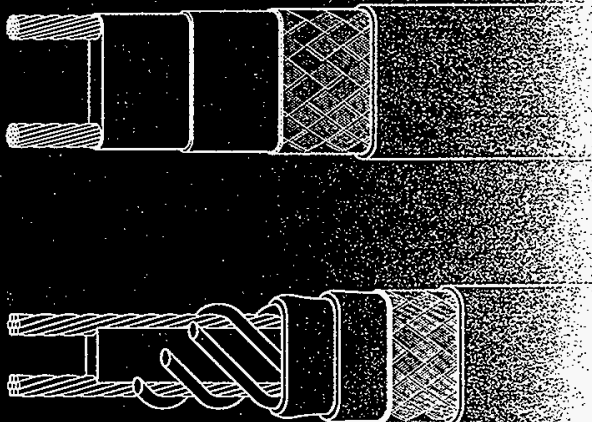

$\checkmark$

HNF-2488, Rev. 0

Page A-27 
This guide outlines a simple procedure for designing and selecting a complete heat-tracing system using Auto-Trace BTV, QTVR, or XTV heating cables.

By following the design steps in the seven sections, a bill of materials can be easily produced which includes the heating cable type, length, components, and accessories needed to install the Auto-Trace heat-tracing system correctly. Use the Design Worksheet and Bill of Materials Summary at the end of this guide to record the design and bill of materials.

\subsection{Thermal Design}

Heat Loss Calculations

\subsection{Heating Cable Selection}

Catalog Number Selection. 4

Plastic Pipe Applications.

\subsection{Electrical Design}

Circuit Breaker Selection .12

Alternate Voltage Adjustment Factors

\subsection{Component Selection and Accessories}

Components. 16

Accessories.

\subsection{Approvals}

6.0 Design Worksheet

.22

\subsection{Bill of Materials Summary}

Computer-aided Design Speeds Selection

To speed the design and selection of a Chemelex Auto-Trace heat-tracing system, the Chemelex TraceCalc ${ }^{3}$ computer program is also available. TraceCalc runs on IBM-PC or compatible computers and calculates heat loss, circuit loading, breaker sizing, and other required design information. The program produces a complete bill of materials, design summary, and line list in minutes.

For a TraceCalc demonstration, contact the nearest Chemelex representative or Raychem field sales office (see back cover).

HNF-2488, Rev. 0

Page A-28 


\subsection{Thermal Design}

To calculate the heat loss that must be replaced by the heating cable, determine:

- $T_{M}$ : Maintenance temperature $\left({ }^{\circ} \mathrm{F}\right)$

- $T_{A}$ : Minimum expected ambient temperature $\left({ }^{\circ} \mathrm{F}\right)$

- $T_{E}$ : Maximum intermittent exposure temperature $\left({ }^{\circ} \mathrm{F}\right)$

- Pipe or tubing size

- Thermal insulation type and thickness

Example:

$T_{M}: 40^{\circ} \mathrm{F}$ (water freeze protection) $T_{A}:-40^{\circ} \mathrm{F}$

$T_{E}: 366^{\circ} \mathrm{F}$ ( $150 \mathrm{psig}$ steam cleaning) Pipe size: 6" steel

Insulation: 2 1/2" calcium silicate

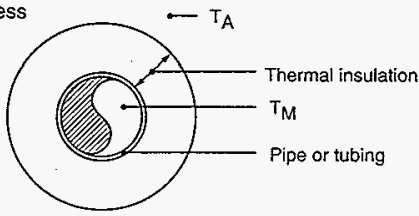

Step 1. Calculate temperature differential.

$$
\begin{aligned}
\Delta T=T_{M}-T_{A} & =T_{M}-T_{A} \\
\text { Calculate } \Delta T^{\circ} & =40^{\circ} \mathrm{F}-\left(-40^{\circ} \mathrm{F}\right) \\
\Delta T & =80^{\circ} \mathrm{F}
\end{aligned}
$$

Note: Heat loss calculations are based on IEEE Std. 515-1989, Equation 1, page 19

Note: Heat losses for valves and pipe supports are addressed in Section 3.0, Step 1.

\section{Step 2. Determine pipe heat loss.}

From Chart 1, match the pipe size and insulation thickness with the temperature differential $\Delta T$ to find the base heat loss of the pipe $\left(Q_{B}\right)$.

From Chart 1 , for $6^{\prime \prime}$ pipe, with $21 / 2^{\prime \prime}$ insulation and $\Delta T=80^{\circ} F, Q_{B}$ must be calculated through interpolation. For this example 80 is $30 / 50$ of the way between $50^{\circ}$ and $100^{\circ}$ :

$\begin{aligned} Q_{B} & =3.6 \mathrm{~W} / \mathrm{ft}+30 / 50 \times(7.4-3.6) \\ & =3.6+2.3 \\ Q_{B} & =5.9 \mathrm{~W} / \mathrm{ft} @ \mathrm{~T}_{M}=40^{\circ} \mathrm{F}\end{aligned}$

\section{Step 3. Compensate for insulation type.}

Multiply the base heat loss of the pipe $\left(Q_{B}\right)$ from Step 2 by the insulation compensation factor ( $t$ ) from the bottom of Chart 1 to get the actual heat loss per foot of pipe $\left(\mathrm{Q}_{\mathrm{T}}\right)$.

$Q_{T}=Q_{B} \times f$

From Chart $1, f=1.50$ for calcium silicate:

$$
\begin{aligned}
Q_{T} & =Q_{B} \times f \\
& =5.9 \mathrm{~W} / \mathrm{ft} \times 1.50 \\
Q_{T} & =8.9 \mathrm{~W} / \mathrm{ft} @ 40^{\circ} \mathrm{F}
\end{aligned}
$$


Pipe Diameter (IPS) in inches

\begin{tabular}{|c|c|c|c|c|c|c|c|c|c|}
\hline \multirow{3}{*}{$\begin{array}{l}\text { Insulation } \\
\text { Thickness }\end{array}$} & \multirow{3}{*}{$\begin{array}{l}\Delta T \\
\left({ }^{\circ} F\right)\end{array}$} & $1 / 4$ & $1 / 2$ & $3 / 4$ & 1 & $11 / 4$ & $11 / 2$ & 2 & $21 / 2$ \\
\hline & & \multicolumn{8}{|c|}{ Tubing Size (inches) } \\
\hline & & $\therefore$ & $3 / 4$ & 1 & $11 / 4$ & $11 / 2$ & 2 & & \\
\hline \multirow[t]{3}{*}{$0.5^{n}$} & 50 & 1.9 & 2.5 & 2.9 & 3.5 & 4.1 & 4.6 & 5.5 & 6.5 \\
\hline & 150 & 6.1 & 8.1 & 9.5 & 11.2 & 13.4 & 14.9 & 17.9 & 21.1 \\
\hline & 200 & 8.5 & 11.3 & 13.2 & 15.6 & 18.6 & 20.7 & 24.9 & 29.2 \\
\hline \multirow{3}{*}{$1.0^{n}$} & 150 & 4.2 & 5.3 & 6.1 & 7.0 & 8.2 & 9.0 & 10.6 & 12.2 \\
\hline & 200 & 5.8 & 7.4 & 8.4 & 9.7 & 11.3 & 12,4 & 14.6 & 16.9 \\
\hline & 250 & 7.6 & 9.7 & 11.0 & 12.7 & 14.8 & 16.3 & 19.1 & 22.1 \\
\hline \multirow[t]{4}{*}{$1.5^{4}$} & 50 & 1.1 & 1.3 & 1.5 & 1.7 & 1.9 & 2.1 & 2.4 & 2.8 \\
\hline & 100 & 2.2 & 2.8 & 3.1 & 3.5 & 4.0 & 4.4 & 5.1 & 5.8 \\
\hline & 150 & 3.5 & 4.3 & 4.8 & 5.5 & 6.3 & 6.9 & 8.0 & 9.1 \\
\hline & 350 & 9.6 & 11.9 & 13.3 & 15.1 & 17.4 & 19.0 & 22.0 & 25.1 \\
\hline \multirow[t]{7}{*}{$2.0^{4}$} & 50 & 0.9 & 1.1 & 1.3 & 1.4 & 1.6 & 1.8 & 2.0 & 2.3 \\
\hline & 100 & 2.0 & 2.4 & 2.7 & 3.0 & 3.4 & 3.7 & 4.2 & 4.8 \\
\hline & 150 & 3.1 & 3.7 & 4.2 & 4.7 & 5.3 & 5.8 & 6.6 & 7.5 \\
\hline & 200 & 4.3 & 5.2 & 5.8 & 6.5 & 7.4 & 8.0 & 9.2 & 10.4 \\
\hline & 250 & 5.6 & 6.8 & 7.5 & 8.5 & 9.6 & 10.4 & 12.0 & 13.5 \\
\hline & 300 & 7.0 & 8.5 & 9.4 & 10.6 & 12.1 & 13.1 & 15.0 & 17.0 \\
\hline & 350 & 8.5 & 10.3 & 17.5 & 12.9 & 14.7 & 15.9 & 18.2 & 20.6 \\
\hline \multirow[t]{3}{*}{$2.5^{n}$} & 50 & 0.9 & 7.0 & 1.2 & 1.3 & 1.4 & 1.6 & 1.8 & 2.0 \\
\hline & 100 & 1.8 & 2.2 & 2.4 & 2.7 & 3.0 & 3.3 & 3.7 & 4.2 \\
\hline & 150 & 2.8 & 3.4 & 3.7 & 4.2 & 4.7 & 5.1 & 5.8 & 6.5 \\
\hline \multirow{3}{*}{$3.0^{\prime \prime}$} & 250 & 4.8 & 5.7 & 6.2 & 6.9 & 7.8 & 8.3 & 9.4 & 10.5 \\
\hline & 300 & 6.0 & 7.1 & 7.8 & 8.7 & 9.7 & 10.4 & 11.8 & 13.2 \\
\hline & 350 & 7.3 & 8.6 & 9.5 & 10.5 & 11.8 & 12.7 & 14.3 & 16.0 \\
\hline \multirow[t]{7}{*}{$4.0^{n}$} & 50 & 0.7 & 0.9 & 0.9 & 1.0 & 1.1 & 1.2 & 1,4 & 1.5 \\
\hline & 100 & 1.5 & 1.8 & 2.0 & 2.1 & 2.4 & 2.5 & 2.9 & 3.2 \\
\hline & 150 & 2.4 & 2.8 & 3.0 & 3.4 & 3.7 & 4.0 & 4.4 & 4.9 \\
\hline & 200 & 3.3 & 3.9 & 4.2 & 4.6 & 5.2 & 5.5 & 6.2 & 6.8 \\
\hline & 250 & 4.3 & 5.1 & 5.5 & 6.1 & 6.7 & 7.2 & 8.1 & 8.9 \\
\hline & 300 & 5.4 & 6.3 & 6.9 & 7.6 & 8.5 & 9.0 & 10.1 & 11.2 \\
\hline & 350 & 6.6 & 7.7 & 8.4 & 9.3 & 10.3 & 11.0 & 12.3 & 13.6 \\
\hline
\end{tabular}

\section{Insulation Factors}

\begin{tabular}{lll}
\hline $\begin{array}{l}\text { Preformed } \\
\text { Pipe Insulation }\end{array}$ & $\begin{array}{l}\text { Insulation Factor } \\
(\mathrm{f})\end{array}$ & $\begin{array}{l}\text { K factor } \\
\text { (BTU/hr- }\end{array}$ \\
\hline Glass Fiber (ASTM C547) & 1.00 & .25 \\
\hline Calcium Silicate (ASTM C533) & 1.50 & .375 \\
\hline Cellular Glass (ASTM C552) & 1.60 & .40 \\
\hline Rigid Cellular Urethane (ASTM C591) & 0.66 & .165 \\
\hline Foamed Elastomer (ASTM C534) & 1.16 & .29 \\
\hline Mineral Fiber Blanket (ASTM C553) & 1.20 & .30 \\
\hline Expanded Perlite (ASTM C610) & 1.50 & .375 \\
\hline
\end{tabular}

HNF-2488, Rev. 0

Page A-30 


\begin{tabular}{lllllllllllll}
3 & $31 / 2$ & 4 & 6 & 8 & 10 & 12 & 14 & 16 & 18 & 20 & 24 \\
\hline
\end{tabular}

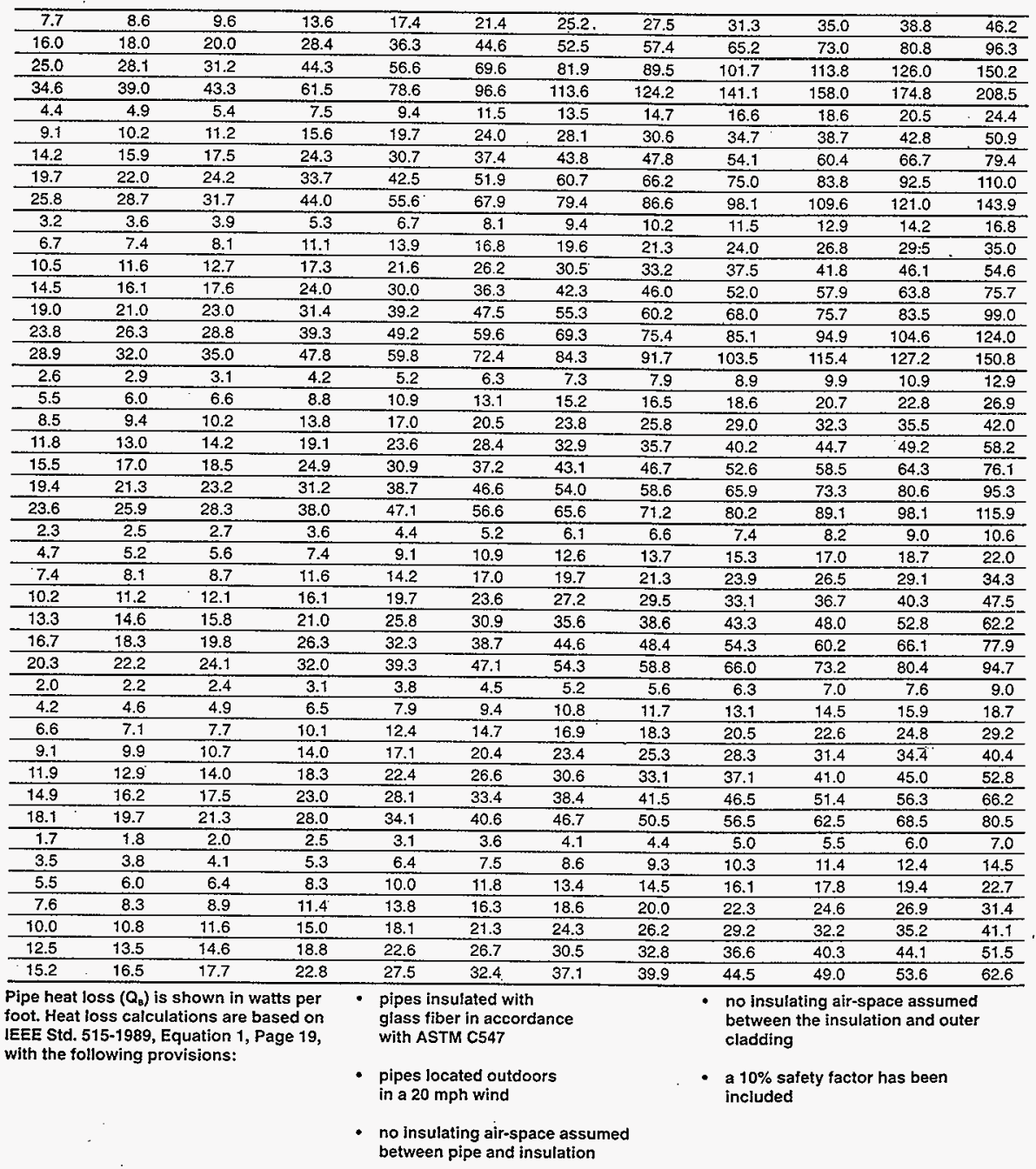


Note: The heating cable selection section is for BTV, QTVR, and XTV heating cables in, base, $-C R$ and $-C T$ versions for Ordinary and Division 2 hazardous areas only. For other products or applications consult the factory or the Chemelex representative.

\subsection{Heating Cable Selection}

To select the heating cable catalog number, determine:

- $\mathrm{T}_{\mathrm{M}}$ : Maintenance temperature $\left({ }^{\circ} \mathrm{F}\right)$

- TE: Maximum intermittent exposure temperature ( ${ }^{\circ} \mathrm{F}$ )

- $Q_{T}$ : Actual heat loss per foot of pipe at $T_{M}$

- Service voltage

- Electrical area classification

- Chemical environment

Example (continued from page1):

$T_{M}=40^{\circ} \mathrm{F}$ (water freeze protection)

$T_{E}=366^{\circ} \mathrm{F}$ (150 psig steam cleaning)

Service voltage: 120 volts

Electrical area classification: Hazardous

(classifjed), CID2

Chemical environment: Corrosive
$\mathrm{Q}_{\mathrm{T}}=8.9 \mathrm{~W} / \mathrm{H} @ 40^{\circ} \mathrm{F}$
You need to find Catalog Number:

Step 2

Thermal Output

Rating

Step 1

Heating Cable Family

Step 3

Voltage Rating

Step 4

Heating Cable Construction

\section{Step 1 . Select the heating cable family.}

Considering the maximum intermittent exposure temperature ( $T_{E}$ ) and the maintenance temperature $\left(T_{M}\right)$, select the appropriate Auto-Trace heating cable family.
BTV
QTVR
XTV

Maximum maintenance $\left(T_{M}\right)$ or continuous exposure-power on

\begin{tabular}{ccc}
\hline $150^{\circ} \mathrm{F}\left(65^{\circ} \mathrm{C}\right)$ & $225^{\circ} \mathrm{F}\left(110^{\circ} \mathrm{C}\right)$ & $250^{\circ} \mathrm{F}\left(121^{\circ} \mathrm{C}\right)$ \\
\hline Maximum continuous exposure-power off & \\
\hline $150^{\circ} \mathrm{F}\left(65^{\circ} \mathrm{C}\right)$ & $225^{\circ} \mathrm{F}\left(110^{\circ} \mathrm{C}\right)$ & $370^{\circ} \mathrm{F}\left(187^{\circ} \mathrm{C}\right)$ \\
\hline
\end{tabular}

Maximum intermittent exposure ( $\left.T_{E}\right)$ up to 1000 cumulative hours -power on

\begin{tabular}{|c|c|c|}
\hline $185^{\circ} \mathrm{F}\left(85^{\circ} \mathrm{C}\right)$ & $225^{\circ} \mathrm{F}\left(110^{\circ} \mathrm{C}\right)$ & $420^{\circ} \mathrm{F}\left(215^{\circ} \mathrm{C}\right)$ \\
\hline \multicolumn{3}{|c|}{ T-rating (Table 500-3 (b) of National Electrical Code, 1990) } \\
\hline $\mathrm{T} 6,185^{\circ} \mathrm{F}\left(65^{\circ} \mathrm{C}\right)$ & $\mathrm{T} 4,275^{\circ} \mathrm{F}\left(135^{\circ} \mathrm{C}\right)$ & $\mathrm{T} 2 \mathrm{C}, 446^{\circ} \mathrm{F}\left(230^{\circ} \mathrm{C}\right)$ \\
\hline & & $\begin{array}{l}\text { [ T3 }\left(392^{\circ} \mathrm{F}, 200^{\circ} \mathrm{C}\right) \\
\text { product available on } \\
\text { request ] }\end{array}$ \\
\hline
\end{tabular}

* If during nomal operation the pipe temperature is expected to exceed $250^{\circ} \mathrm{F}$ (12 $\mathrm{r}^{\circ} \mathrm{C}$ ), thermostatic control is required. To estimate pipe temperature, use Chemelex TraceCalc or call the Chemelex representative.

Heating cable family selection: For intermittent exposure to $366^{\circ} \mathrm{F}\left(185^{\circ} \mathrm{C}\right)$, select XTV.

Heating cable family: XTV

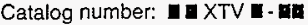

HNF-2488, Rev. 0

Page A-32 
From Chart $3 a$ or $3 b$, match the actual heat loss per foot of pipe $\left(Q_{T}\right)$ with the maintenance temperature $\left(T_{M}\right)$, and select the thermal output ratings for which the rating at $T_{M}$ equals or exceeds $Q_{T}$.

From Chart $3 \mathrm{~b}, 10 \times T V$ exceeds $8.9 \mathrm{~W} / \mathrm{tt}$ at $40^{\circ} \mathrm{F}$. Select $10 \times T V$.

Thermal output rating: 10

Catalog number: 10XTVח- $\mathbf{m}$

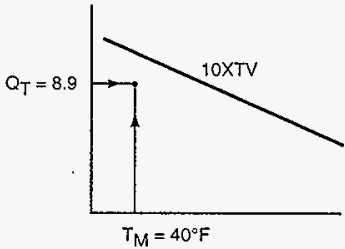

Note: If plastic pipe is used, see Chait 4 for BTV thermal output adjustment factors. Auto-Trace QTVR and XTV are not recommended for plastic pipe applications as they may exceed the temperature rating of the pipe material.

Note: If the service voltage is 208 or 277 volts, multiply the thermal output rating of the 240 volt heating cable by the appropriate power output factor in Chart 7.

This will give the adjusted power output at the service vollage.

If the heat loss $Q_{T}$ is in between the two heating cable thermal output curves, select the higher rated heating cable. If the heat loss $Q_{T}$ is greater than the thermal output of the highest rated heating cable you can:

a) use thicker insulation

b) use insulation material with a lower $K$ factor

c) use two or more heating cables run in parallel

d) spiral the heating cable

Spiraling: If spiraling is elected, determine the spiral factor according to the following formula:

Spiral factor (length of heating cable/foot of pipe) $=\frac{Q_{T}}{\text { Heater thermal output at } T_{M}}$

When the spiral factor exceeds 1.6 or the pipe size is less than 3 IPS, consider using two or more heating cables run in parallel.

Step 3. Select the voltage rating.

Service voltage options:

$1 \equiv 120$ volts $(100-130 \mathrm{Vac})$

$2 \equiv 240$ volts $(200-277 \mathrm{Vac})$

Available service voltage: 120 volts.

Select 120 -volt version of 10XTV.

Voltage rating: 1

Catalog number: $10 \times T V 1-{ }^{-1}$

HNF-2488, Rev. 0

Page A-33 
Note: This example is continued on page 12 for metal pipes. For plastic pipes, use the example on page 10.

\section{Step 4 Select the heating cable options.}

Select the appropriate heating cable options from Chart 2 considering the electrical area classification and chemical environment.

Whenever a heating cable with braid (ground path) and outer jacket is selected, -CT (or-CR for BTV heating cables) is added to the catalog number.

From Chart 2, -CT is indicated for hazardous (classified) CID2 areas and for exposure to corrosive chemicals. Select the $-C T$ options of $10 \times T V 1$.

Heating cable option: -CT

Catalog number: 10XTV1-CT

\section{Chart 2 Chemelex Auto-Trace Heating Cable Options}

\begin{tabular}{lccc} 
Heating Cable Options & Base & $-\mathrm{CR}$ & $-\mathrm{CT}$ \\
\hline Area Classification: & & $\bullet$ & $\bullet$ \\
\hline Hazardous 1 & $\bullet$ & $\bullet$ & $\bullet$ \\
\hline Ordinary & $\bullet$ & $\bullet$ & $\bullet$ \\
\hline Heat-traced Surface Type: & $\bullet$ & $\bullet$ & $\bullet$ \\
\hline Carbon Steel & & $\bullet$ & $\bullet$ \\
\hline Stainless Steel & & $\bullet$ & $\bullet$ \\
\hline Pastic & & & $\bullet$ \\
\hline Chemical Resistance: ${ }^{2}$ & & $\bullet$ & $\bullet$ \\
\hline Organics and Corrosives & $\bullet$ & $\bullet$ \\
\hline Mild Inorganic Solutions & & $\bullet$ \\
\hline Ground Path for Electrical Protection ${ }^{3}$ & & & $\bullet$ \\
\hline
\end{tabular}

1 For FM approvals and CSA certifications see Section 5.0, Approvals for area classification.

2 Heating cables are not recommended for continuous exposure. For strong corrosives and organics consult Chemelex.

3 NEC Section 427-22, 1990 requires a Ground Fault Equipment Protection Device for supplying electric heating equipment not having a metal covering.

HNF-2488, Rev. 0

Page A-34 
Auto-Trace XTV Heating Cables

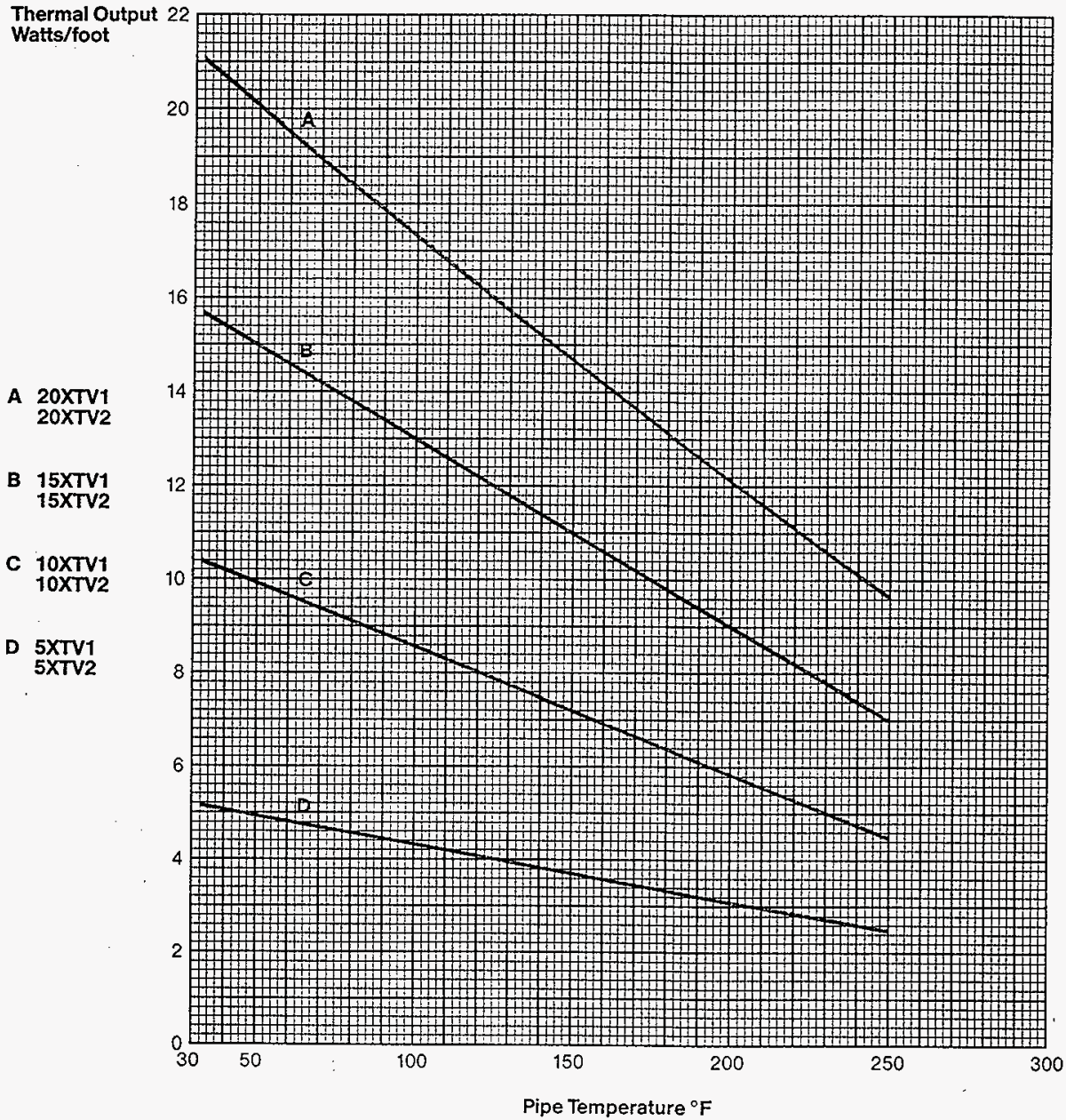

Note: Watts $/$ foot $\times 3.28=$ Watts $/$ meter

$\left({ }^{\circ} \mathrm{F}-32\right) \times{ }^{5 / 9}={ }^{\circ} \mathrm{C}$

HNF-2488, Rev. 0

Page A-35 


\section{BTV Heating Cable Selection for Insulated Plastic Pipes}

BTV heating cable with braid and outer jacket is ideal for heat-tracing plastic pipes.

However, increased resistance to heat transfer from the heating cable to the plastic pipe necessitates compensation of its thermal output. Aluminum tape may be used to increase the thermal output of BTV heating cables on plastic pipes. For tape specifications, see Chart 9 .

The thermal output adjustment factors for typical applications are shown below.

\section{Chart 4 Thermal Output Adjustment Factors}

Pipe Wall Thickness $0.250^{\prime \prime}$ or Less*

\begin{tabular}{lll}
$\begin{array}{l}\text { CT or }-\mathrm{CR} \\
\text { Heating Cable }\end{array}$ & $\begin{array}{l}\text { Glass Tape } \\
\text { Across Heating Cable }\end{array}$ & $\begin{array}{l}\text { Aluminum Tape } \\
\text { Over Heating Cable }\end{array}$ \\
\hline 3BTV1 & 0.55 & 0.80 \\
\hline 3BTV2 & 0.60 & 0.75 \\
\hline 5BTV1 & 0.55 & 0.75 \\
\hline 5BTV2 & 0.50 & 0.75 \\
\hline 8BTV1 & 0.50 & 0.70 \\
\hline 8BTV2 & 0.45 & 0.65 \\
\hline 10BTV1 & 0.40 & 0.60 \\
\hline 10BTV2 & 0.45 & 0.70 \\
\hline
\end{tabular}

"Equivalent to a $31 / 2$ " schedule 40 PVC pipe. For greater pipe wall thickness consult the tactory or the Chemelex representative.

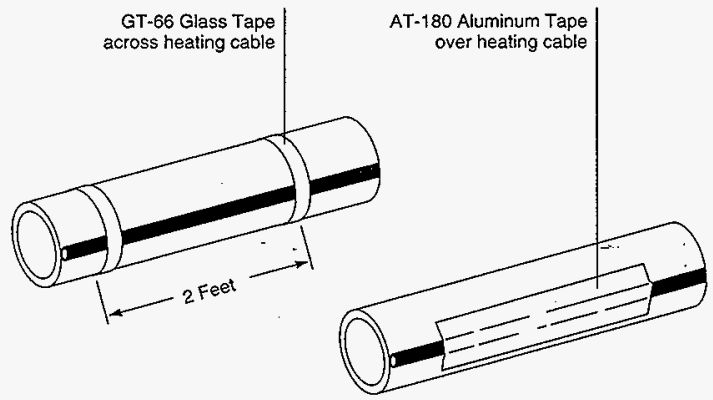

HNF-2488, Rev. 0

Page A-36 


\section{BTV Heating Cable Selection for Insulated Plastic Pipes}

To select the catalog number for BTV on plastic pipe, follow the next five steps.

Plastic pipe example:

Pipe size: 2 1/2" schedule 40

Pipe material: PVC

Insulation: 1 " glass fiber

$\mathrm{T}_{\mathrm{M}}: \quad 40^{\circ} \mathrm{F}$

$\mathrm{T}_{\mathrm{A}}:-10^{\circ} \mathrm{F}$

$T_{E}: 140^{\circ} \mathrm{F}$

Service voltage: 120 volts

Electrical area classification: Ordinary

Chemical exposure: None

Step 1. Calculate temperature differential.

$\Delta T=T_{M} \cdot T_{A}$

$$
\text { Calculate } \begin{aligned}
\Delta T & =T_{M}-T_{A} \\
& =40^{\circ} F-\left(-10^{\circ} \mathrm{F}\right) \\
\Delta T & =50^{\circ} \mathrm{F}
\end{aligned}
$$

\section{Step 2. Determine pipe heat loss.}

From Chart 1, match the pipe size and insulation thickness with the temperature differential $(\Delta T)$ to find the base heat loss of the pipe $\left(Q_{B}\right)$.

From Chart 1 , for $21 / 2^{\prime \prime}$ pipe, with $1 "$ insulation and $\Delta T=50^{\circ} \mathrm{F}$, the heat loss is $3.8 \mathrm{~W} / \mathrm{ft}$

$\mathrm{QB}=3.8 \mathrm{~W} / \mathrm{ft} @ \mathrm{~T}_{\mathrm{M}}=40^{\circ} \mathrm{F}$

\section{Step 3. Compensate for insulation type.}

Multiply the base heat loss of the pipe $\left(Q_{B}\right)$ from Step 2 by the insulation factor (f) from Chart 1 to get the actual heat loss $\left(Q_{T}\right)$.

$Q_{T}=Q_{B} \times f$

From Chart $1, f=1.00$ for glass fiber:

$Q_{T}=Q_{B} \times f$

$=3.8 \mathrm{~W} / \mathrm{ft} \times 1.00$

$\mathrm{Q}_{\mathrm{T}}=3.8 \mathrm{~W} / \mathrm{ft} @ 40^{\circ} \mathrm{F}$

\section{Step 4. Select the heating cable family, voltage rating, and options.}

For a plastic pipe application with a service voltage of 120 volts, select BTV1.

From Chart 2, a ground path is required for plastic pipe. Select -CR option for BTV since there is no chemical exposure.

Heating cable $=\mathrm{BTV} 1-\mathrm{CR}$

HNF-2488, Rev. 0

Page A-37 
Step 5. Select the thermal output rating.

Determine the adjusted thermal output of BTV at the maintenance temperature $\left(T_{M}\right)$ when on plastic pipe. Then select the BTV heating cable for which the adjusted thermal output at $T_{M}$ equals or exceeds the actual heat loss $\left(Q_{T}\right)$.

From Chart $3 a$, the thermal output of $5 \mathrm{BTV} 1$ at $40^{\circ} \mathrm{F}$ equals $5.7 \mathrm{~W} / \mathrm{ft}$; and from Chart 4 , the thermal output adjustment factors are 0.55 (using giass tape) and 0.75 (using aluminum tape). If aluminum tape is used, the adjusted thermal output exceeds QT:

$5.7 \mathrm{~W} / \mathrm{tt} \times 0.75=4.3 \mathrm{~W} / \mathrm{it}$

(this exceeds $Q_{T}$, which is $3.8 \mathrm{~W} / \mathrm{t}$ )

Thermal output rating: 5

Catalog number: 5BTV1-CR

HNF-2488, Rev. 0

Page A-38 


\subsection{Electrical Design}

To select the circuit breaker sizing, determine:

- $T_{M}$ : Maintenance temperature $\left({ }^{\circ} \mathrm{F}\right)$

- QT: Actual heat loss per foot of pipe at $T_{M}$

- Pipe or tubing size

- Pipe length

- Type and number of valves and pipe supports

- Heating cable catalog number

- Minimum startup temperature $\left({ }^{\circ} \mathrm{F}\right)$

Example (continued from page 6):

$T_{M}: 40^{\circ} \mathrm{F}$

QT: $8.9 \mathrm{~W} / \mathrm{ft} @ 40^{\circ} \mathrm{F}$

Pipe size: 6" steel

Pipe length: $100 \mathrm{ft}$

Valves: Gate, 3 each

Pipe supports: Support shoes, 5 each, 1 -foot length

Heating cable catalog number: 10XTV1-CT

Minimum startup temperature: $0^{\circ} \mathrm{F}$

Power connection kit: 1

End seal: 1

Step 1. Calculate the total length of heating cable required by combining lengths from each component of the piping system.

For the pipe: Determine the amount of heating cable required for the pipeline length.

Piping: $100 \mathrm{ft}$ of pipe $=100 \mathrm{tt}$

For each valve: Add a heating cable length determined by multiplying $Q_{T}$ by the valve heat loss factor from Chart 5 and dividing by the heating cable thermal output at $T_{M}$.

Valves: 3 valves $\times \frac{(8.9 \mathrm{~W} / \mathrm{ft} \times 4.3 \mathrm{ft})}{10.2 \mathrm{~W} / \mathrm{tt}}=11.2 \mathrm{ft}$

For each pipe support shoe calculate the additional heat required as follows:

$Q_{\text {SUPPORT }}=0.7 \mathrm{~L} \times\left(T_{M}-T_{A}\right)$, where $L=$ support length $(\mathrm{ft})$

This formula is based on a 0.25 " steel welded shoe partially shielded from winds.

Heat loss from supports: $5 \times[1 \times 0.7 \times 80]=280 \mathrm{~W}$

Calculate the additional heating cable required by dividing the total support heat loss by the heating cable power output per foot at $T_{M}$ from Chart 3a or 3b.

Heating cable required for supports $=\frac{280 \mathrm{~W}}{10.2 \mathrm{~W} / \mathrm{ft}}=27.5 \mathrm{ft}$

Total heating cable: $(A)+(B)+(C)=100+11.2+27.5=138.7 \mathrm{ft}$

Components: Allow an additional $3 \mathrm{ft}$ for each component.

Total heating cable to be used: $138.7+3+3=144.7 \mathrm{ft}$

HNF-2488, Rev. 0

Page A-39 
HNF-2488, Rev. 0

Page A-40

Chart 5 Valve Heat Loss Factors

\begin{tabular}{ll} 
Valve Type & Heat Loss Factor \\
\hline Gate & 4.3 \\
\hline Butterfly & 2.3 \\
\hline Ball & 2.6 \\
\hline Globe & 3.9 \\
\hline
\end{tabular}

Example: Heat loss for a 2" gate valve is 4,3 times the heat loss for one foot of pipe of the same size and insulation.

\section{Step 2. Determine the circuit breaker trip rating.}

Using Chart 6, match the heating cable catalog number at the expected minimum startup temperature with the total heating cable length and select a circuit breaker trip rating. Circuit breaker trip rating should not exceed the maximum trip rating shown for heating cables of that product family. For example, the trip rating of a circuit breaker protecting several XTV circuits should not exceed 50 amps. To maximize fault current protection use the lowest allowable circuit breaker sizing.

From Step 1, the total heating cable circuit length is 144.7 feet. From Chart 6 , the maximum heating cable length allowed for $10 X T V$ powered at 120 volts with a $0^{\circ} \mathrm{F}$ startup temperature on a $20 \mathrm{amp}$ circuit breaker is 130 feet, and on a $30 \mathrm{amp}$ breaker is 195 feet. Select the $30 \mathrm{amp}$ circuit breaker.

Circuit breaker trip rating: 30 amps

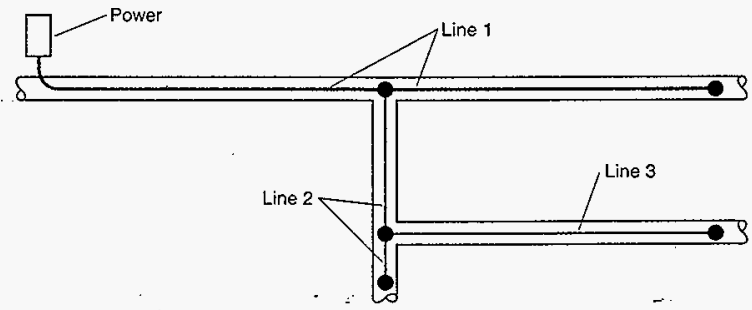

Line $1+$ Line $2+$ Line $3 \leq$ Maximum Circuit length

\section{Step 3. Select the circuit breaker}

\section{Ground Fault Protection}

The IEEE standard (515-1989) for heating cables recommends the use of GFEPDs with a nominal 30 milliampere trip level "for piping systems in classified areas requiring a high degree of maintenance, or which may be exposed to physical abuse or corrosive atmospheres."

Article 427-22 of the 1990 National Electrical Code requires the use of GFEPD with non braided (base) electric heating cables.

\section{Device selection}

Using the information below, select the appropriate device for the system.

Ground Fault Equipment

Protection Devices

- Square D

Type QOB-EPD

- Westinghouse Types GFEP, GFEPD
Conventional Devices

- General Electric

Type TEB

- Square D

Types EH, QO

- Westinghouse Types BA, GH 


\section{Chart 6 Circuit Breaker Selection}

Circuit breaker trip ratings are based on Article 427.4 of the 1990 National Electrical Code, which says in part "....the rating or setting of overcurrent devices supplying fixed electric heating equipment for pipelines and vessels shall not be less than 125 percent of the total load of the heating cable."

Maximum Heating Cable Length (feet) vs. Circuit Breaker Trip Rating (amps)

Heating 120 volts 240 volts

\begin{tabular}{|c|c|c|c|c|c|c|c|c|c|c|c|}
\hline \multirow[b]{2}{*}{ Cabl } & \multirow[b]{2}{*}{ Startup Temp. } & & & & & & \\
\hline & & $15 \mathrm{~A}$ & $20 \mathrm{~A}$ & $30 \mathrm{~A}$ & $40 \mathrm{~A}$ & $50 \mathrm{~A}$ & $15 \mathrm{~A}$ & $20 \mathrm{~A}$ & $30 \mathrm{~A}$ & $40 A$ & $50 \mathrm{~A}$ \\
\hline \multirow[t]{4}{*}{ 3BTV } & $50^{\circ} \mathrm{F}$ & 330 & 330 & 330 & 330 & - & 660 & 660 & 660 & 660 & - \\
\hline & $\mathrm{O}^{\circ} \mathrm{F}$ & 195 & 265 & 330 & 330 & - & 395 & 530 & 660 & 660 & $\therefore$ \\
\hline & $-20^{\circ} \mathrm{F}$ & 170 & 225 & 330 & 330 & - & 340 & 455 & 660 & 660 & $=$ \\
\hline & $-40^{\circ} \mathrm{F}$ & 145 & 195 & 295 & 330 & $\cdot$ & 295 & 395 & 595 & 660 & - \\
\hline \multirow[t]{4}{*}{ 5BTV } & $50^{\circ} \mathrm{F}$ & 230 & 270 & 270 & 270 & $\cdot$ & 460 & 540 & 540 & 540 & $\therefore$ \\
\hline & $\mathrm{O}^{\circ} \mathrm{F}$ & 140 & 185 & 270 & 270 & - & 280 & 375 & 540 & 540 & - \\
\hline & $-20^{\circ} \mathrm{F}$ & 120 & 160 & 245 & 270 & - & 245 & 325 & 490 & 540 & - \\
\hline & $-40^{\circ} \mathrm{F}$ & 105 & 145 & 215 & 270 & - & 215 & 290 & 435 & 540 & - \\
\hline \multirow[t]{4}{*}{ 8BTV } & $50^{\circ} \mathrm{F}$ & 150 & 200 & 210 & 210 & - & 300 & 400 & 420 & 420 & - \\
\hline & $0^{\circ} \mathrm{F}$ & 100 & 130 & 200 & 210 & - & 200 & 265 & 400 & 420 & - \\
\hline & $-20^{\circ} \mathrm{F}$ & 85 & 115 & 175 & 210 & - & 175 & 235 & 350 & 420 & - \\
\hline & $-40^{\circ} \mathrm{F}$ & 75 & 105 & 155 & 210 & - & 155 & 210 & 315 & 420 & - \\
\hline \multirow[t]{4}{*}{ 10BTV } & $50^{\circ} \mathrm{F}$ & 120 & 160 & 180 & 180 & - & 240 & 320 & 360 & 360 & - \\
\hline & $0^{\circ} \mathrm{F}$ & 75 & 105 & 155 & 180 & - & 155 & 210 & 315 & 360 & $=$ \\
\hline & $-20^{\circ} \mathrm{F}$ & 65 & 90 & 135 & 180 & - & 135 & 185 & 275 & 360 & - \\
\hline & $-40^{\circ} \mathrm{F}$ & 60 & 80 & 120 & 165 & - & 120 & 165 & 245 & 330 & $=$ \\
\hline \multirow[t]{4}{*}{ 10QTVR } & $50^{\circ} \mathrm{F}$ & 100 & 130 & 195 & 195 & - & 200 & 265 & 390 & 390 & - \\
\hline & $0^{\circ} \mathrm{F}$ & 80 & 105 & 160 & 195 & - & 160 & 210 & 320 & 390 & - \\
\hline & $-20^{\circ} \mathrm{F}$ & 70 & 95 & 145 & 195 & - & 145 & 195 & 295 & 390 & - \\
\hline & $-40^{\circ} \mathrm{F}$ & 65 & 90 & 135 & 180 & - & 135 & 180 & 275 & 365 & - \\
\hline \multirow[t]{4}{*}{ 15QTVR } & $50^{\circ} \mathrm{F}$ & 75 & 100 & 150 & 200 & 220 & 160 & 210 & 320 & 340 & - \\
\hline & $0^{\circ} \mathrm{F}$ & 60 & 80 & 120 & 160 & 200 & 125 & 170 & 255 & 340 & - \\
\hline & $-20^{\circ} \mathrm{F}$ & 55 & 70 & 110 & 145 & 185 & 115 & 155 & 235 & 315 & - \\
\hline & $-40^{\circ} \mathrm{F}$ & 50 & 65 & 100 & 135 & 170 & 110 & 145 & 220 & 290 & - \\
\hline \multirow[t]{4}{*}{ 20QTVR } & $50^{\circ} \mathrm{F}$ & 60 & 80 & 120 & 160 & 195 & 120 & 160 & 240 & 320 & 390 \\
\hline & $0^{\circ} \mathrm{F}$ & 45 & 60 & 95 & 125 & 160 & 95 & 125 & 190 & 255 & 320 \\
\hline & $-20^{\circ} \mathrm{F}$ & 40 & 55 & 85 & 115 & 145 & 85 & 115 & 175 & 235 & 295 \\
\hline & $-40^{\circ} \mathrm{F}$ & 40 & 55 & 80 & 110 & 135 & 80 & 110 & 165 & 220 & 275 \\
\hline \multirow[t]{4}{*}{ 5XTV } & $50^{\circ} \mathrm{F}$ & 180 & 240 & 360 & 380 & 380 & 360 & 480 & 720 & 765 & 765 \\
\hline & $0^{\circ} \mathrm{F}$ & 160 & 215 & 325 & 380 & 380 & 320 & 425 & 640 & 765 & 765 \\
\hline & $-20^{\circ} \mathrm{F}$ & 155 & 210 & 315 & 380 & 380 & 305 & 410 & 615 & 765 & 765 \\
\hline & $-40^{\circ} \mathrm{F}$ & 150 & 200 & 305 & 380 & 380 & 295 & 390 & 590 & 765 & 765 \\
\hline \multirow[t]{4}{*}{$10 \times T V$} & $50^{\circ} \mathrm{F}$ & 110 & 145 & 220 & 270 & 270 & 220 & 295 & 440 & 540 & 540 \\
\hline & $0^{\circ} \mathrm{F}$ & 95 & 130 & 195 & 265 & 270 & 195 & 260 & 390 & 520 & 540 \\
\hline & $-20^{\circ} \mathrm{F}$ & 95 & 125 & 190 & 255 & 270 & 185 & 245 & 370 & 495 & 540 \\
\hline & $-40^{\circ} \mathrm{F}$ & 90 & 120 & 180 & 245 & 270 & 175 & 235 & 355 & 475 & 540 \\
\hline \multirow[t]{4}{*}{$15 \times T V$} & $50^{\circ} \mathrm{F}$ & 75 & 100 & 150 & 200 & 220 & 150 & 200 & 300 & 400 & 440 \\
\hline & $\mathrm{O}^{\circ} \mathrm{F}$ & 65 & 90 & 135 & 180 & 220 & 130 & 175 & 265 & 355 & 440 \\
\hline & $-20^{\circ} \mathrm{F}$ & 65 & 85 & 130 & 170. & 215 & 125 & 170 & 255 & 340 & 425 \\
\hline & $-40^{\circ} \mathrm{F}$ & 60 & 80 & 125 & 165 & 205 & 120 & 160 & 240 & 325 & 405 \\
\hline \multirow[t]{4}{*}{ 20XTV } & $50^{\circ} \mathrm{F}$ & 60 & 80 & 120 & 160 & 190 & 115 & 150 & 230 & 305 & 380 \\
\hline & $0^{\circ} \mathrm{F}$ & 50 & 70 & 105 & 140 & 175 & 100 & 135 & 200 & 270 & 335 \\
\hline & $-20^{\circ} \mathrm{F}$ & 50 & 65 & 100 & 135 & 170 & 95 & 125 & 190 & 255 & 320 \\
\hline & $-40^{\circ} \mathrm{F}$ & 45 & 65 & 95 & 130 & 165 & 90 & 120 & 185 & 245 & 310 \\
\hline
\end{tabular}

When using 240 volt Auto-Trace heating cables at operating voltages of either 208 or 277 volts, use the circuit length adjustment factors in Chart 7 . 


\section{Chart 7 Alternate Voltage Adjustment Factors}

Chemelex Auto-Trace heating cables can be used with nominal variations in operating voltages without causing significant changes in power output.

Chart 7 shows the effect of alternate voltages on 240-volt Chemelex Auto-Trace heating cables relative to the nominal thermal output rating.

Note: When using circuit length adjustment factors, do not exceed the maximum circuit lengths shown in Chart 7.

\begin{tabular}{|c|c|c|c|c|}
\hline \multicolumn{5}{|c|}{ Operating voltage: 208 Volts } \\
\hline $\begin{array}{l}\text { Heating } \\
\text { Cable }\end{array}$ & $\begin{array}{l}\text { Thermal } \\
\text { Output } \\
\text { Adjustment Factor }\end{array}$ & $\begin{array}{l}\text { Circuit Length } \\
\text { Adjustment Factor }\end{array}$ & $\begin{array}{l}\text { Maximum } \\
\text { Heating Cable } \\
\text { Circuit Length }\end{array}$ & \\
\hline 3BTV2 & 0.82 & 0.99 & 630 teet & \\
\hline $5 \mathrm{BTV2}$ & 0.85 & 0.99 & 500 feet & \\
\hline 8BTV2 & 0.89 & 0.93 & 385 feet & \\
\hline 10BTV2 & 0.89 & 0.93 & 330 feet & \\
\hline 100TVR2 & 0.85 & 0.98 & 365 teet & $\therefore$ \\
\hline 15QTVR2 & 0.91 & 0.91 & 305 feet & \\
\hline 20QTVR2 & 0.90 & 0.92 & 350 feet & \\
\hline $5 \times 1 / 2$ & 0.84 & 1.00 & 720 feet & \\
\hline $10 \times T V 2$ & 0.83 & 0.98 & 510 feet & \\
\hline $15 \times T V 2$ & 0.85 & 0.97 & 415 teet & \\
\hline $20 \times T V 2$ & 0.88 & 0.97 & 350 feet & \\
\hline \multicolumn{5}{|c|}{ Operating voltage: 277 Volts } \\
\hline 3BTV2 & 1.13 & 1.03 & 710 feet & \\
\hline 5BTV2 & 1.12 & 1.07 & 585 feet & \\
\hline 8BTV2 & 1.08 & 1.08 & 465 feet & \\
\hline 10BTV2 & 1.08 & 1.05 & 395 feet & \\
\hline 10QTVR2 & 1.18 & 0.96 & 410 feet & \\
\hline 15QTVR2 & 1.09 & 1.06 & 370 feet & \\
\hline 200TVR2 & 1.07 & 1.06 & 430 feet & \\
\hline 5XTV2 & 1.18 & 1.03 & 750 feet & \\
\hline $10 \times \mathrm{TV} 2$ & 1.17 & 1.06 & 575 feet & \\
\hline $15 \times T V 2$ & 1.13 & 1.08 & 475 feet & \\
\hline $20 \times T V 2$ & 1.10 & 1.11 & 440 feet & \\
\hline
\end{tabular}

Example 1:

Adjust the thermal output of 8 BTV2 powered at 208 volts:

The thermal output of $8 \mathrm{BTV} 2$ at $50^{\circ} \mathrm{F}$ is $8 \mathrm{~W} / \mathrm{ft}$. From Chart 7 , the thermal output of $8 B T V 2$ if powered at 208 volts is 0.89 .

Adjusted thermal output:

$8 \mathrm{~W} / \mathrm{ft} \times 0.89=7.1 \mathrm{~W} / \mathrm{ft} @ 208$ volts

Example 2:

To find the maximum heating cable circuit length for $8 B T V 2$ if started at $50^{\circ} \mathrm{F}$ and powered at 208 volts:

From Chart 6 , the maximum circuit length for $8 B$ TV2 is 300 feet when started at $50^{\circ} \mathrm{F}$ on a 15 amp circuit breaker.

From Chart 7, the circuit length adjustment factor for $8 B T V 2$ is 0.93 powered at 208 volts.

Adjusted maximum circuit length: $300 \mathrm{ft} \times 0.93=279 \mathrm{ft} @ 208$ volts Maximum Heating Cable Circuit Length: $279 \mathrm{ft}$ 


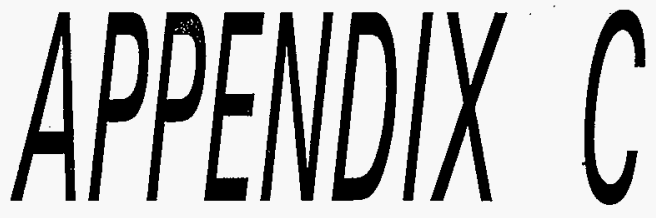

8 PAGES

HNF-2488, Rev. 0

Page A-43 
12606 N.E. 95th Sireet, Sulte C-130 5302 North Millview Drive Vancouver, WA 98682 (206) $896-9910$

Fax; $|206| 896.9905$
Spokane, WA 99212

(509) $926-3284$

Fax: 1509$) 926.3529$
2928 - 162nd Street S.E. Mill Creek, WA 98012

(206) $402-0427$

ICF KAISER HANFORD

P.O. BOX 888

Richland, WA 99352

Attention: Mr. Dick Graber

Subject: Raychen Heat Trace Requirement

Dear D1ck:

Thank you for the opportunity to work with you on the referenced application. We are pleased to offer the following for your consideration:

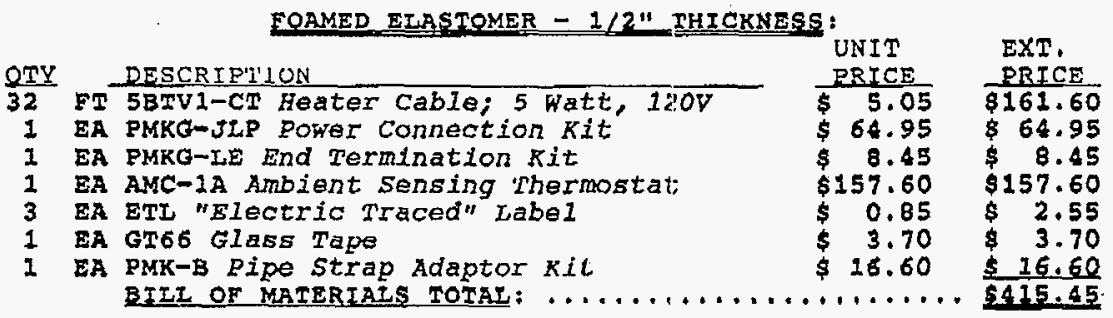

\section{I/2" FIBERCIASS OR I" FOAMYD ETASTOMER:}

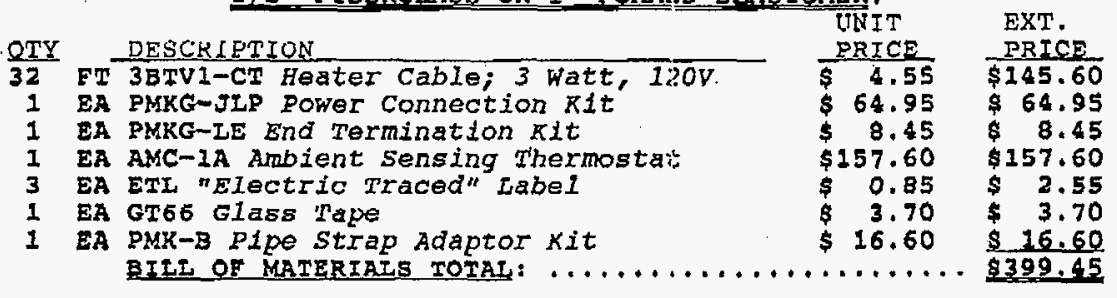

Prices quoted remain valid fur thirty days from date of quote. The FOB point is Vancouver, WA and paymint terms are net 30 days from date of invoice. The standard leat ine for these items is 1 week after receipt of order, or soone: (items shown are normally stocked in vancouver).

HNF-2488, Rev. 0

Page A-44 
Mr. Dick Graber

ICF Kaiser Hanford

please give us a call if you need any more detail regarding this application. Thanks again for the chance to quote.

sjocerely,

FIELD INSTRUMENTS \& CONTROLS

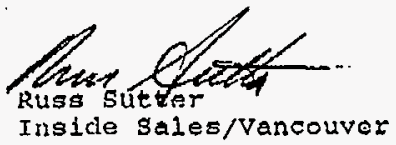

rls

Enclosures

vc: Jamie sullivan/Spokane 
Prolect Nami: FLEX DONE FOr: DICK GRABER DONE BY: RUSS SUTTER Design Name: FLEX Project 10: ICrkaI Design 10: ICFKaI Lines ID: ICFKAI

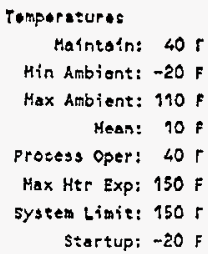

InSU'.etion: FORNED ELASTOHER

(ASTM [534-70)

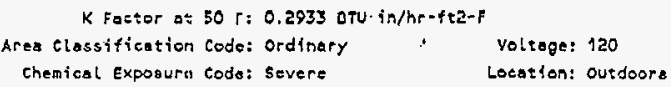

Locatien: outdoore

Maximum CB Load: $32 A$

Pipe Category: IPS/Stcel

Suppors HL Factor: $0.00 \mathrm{ft}$ Valve Hl. factor: 0.00 tt

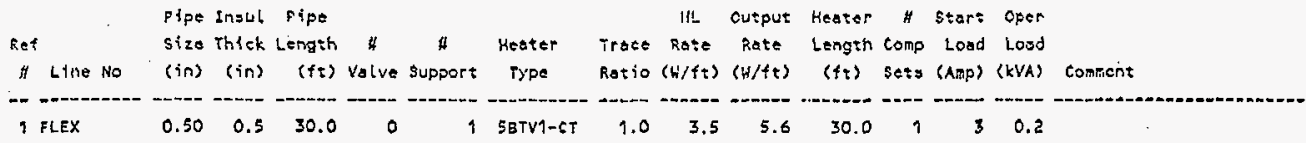

Notes:

Deta used in this design assumes that pipe supports are thermally insulesed from she pipes; therefore, no hesting eable it included for tracing suppors, Raychem recommends that you verify the correctneis of this aseumption as pipe supporto often caufe Substantial heat losacs which should be comperisated by heot tracing.

To alu electrical design, Tracelalc provides electrical circuit load estimatos bzised on the totel heating cable length. However,

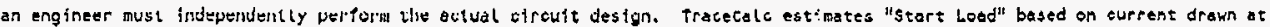
slert-wp telimplature. Tracetale estimates the operating lood ("Oper Lood") basel on power output at maintain temperature, for detailed sizing information, consult the Raychem clectrical protection Bulletin sir contact your Royehem representative.

In accordance with LEEE Heat-Tracing Design Recommended Pructite, Reycliem recommonds the uso of Ground raule fireuit Breakers for jiping systems in elassified aroas requiring a high degres of malnterance, or which may be oxposed to physleal abuse or eorrosive atmospheres.

All of the juformation contained in the progran or deslyns preduced by it are believed to be rellable. However, users should independently ovaluate the suttabllity of each design for theip own soplication. Raychem makes no worranties as to the accuracy or completeness of the information, and disciains any llavilliy rejarding its use. Raychem's only obligetione are those in the Standsrd terms dild conditions of sale for this praduct and other products, and it, no cade will raychem be lisible tor any incidental, indirect, or consequential dameges arkaing frem izo sale, rosole, use, or misuee.

HNF-2488, Rev. 0 
RAYCHE H

Chanelex Division

Projete Name: FLEX

Done for: DICK GRADER

Done BY: RUSS SUTIER

Design Name: FLEX

Project 10: ICFKAI

Design 10: ICFKAI

Lines ID: ICFKA:

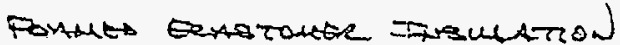

Tracecale IV3.0/10H1A-A15-SN1667:

D. ign sumary

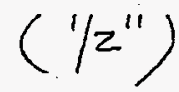

P*g0 1 of 1

30-Dec-94 16:22:09

\author{
Tomporatures \\ Maintain: $40 \mathrm{~F}$ \\ Min Ambien: $-20 r$ \\ Max Ambient: $110 \mathrm{f}$ \\ Mean: $10 \mathrm{~F}$ \\ rrocest oper: $40 \mathrm{~F}$ \\ Max H:P Exp: $150 \mathrm{~F}$ \\ System Limit: $150 \mathrm{~F}$ \\ startup: $-20 \mathrm{f}$
}

\section{Insu;ation: FOAHEO ELASTOMER \\ (ASTM C534-7O) \\ K Fucter or $50 \mathrm{~F}: 0.2933 \mathrm{BTU}-\mathrm{in} / \mathrm{hr}-\mathrm{tt2}-\mathrm{f}$}

Arod clasalflcotion code: ordinary

themical Exposure Code: Severe

heat Loss sofety pactor: $10 x$

Pipe Length per support: $20 \mathrm{ft}$

hllow spirulling: No

Allow Uncontrolled: Yes
Voltage: 120

Location: Outdoore

Maximum CB Lead: $32 \mathrm{~A}$

Pipe tategory: IPS/Stest

Support H: Factor: $0.00 \mathrm{ft}$

Valva HL Fator: $0.00 \mathrm{ft}$

\begin{tabular}{|c|c|c|c|c|c|c|c|c|c|c|c|c|c|c|c|c|c|}
\hline DS & Plpe & Insut & HL & & output & feet & of the & oator & & Min & $\operatorname{Max}$ & & Start & Oper & teral & Total & Total \\
\hline$R \in$ r & silt & Thlok & Rate & Heater & Rate & $/ f t$ & per & par & Fitch & $T$ & $T$ & K racter & Loed & Lond & Fipe & Hester & Comp \\
\hline$H$ & (in) & $(\operatorname{lin})$ & $\langle h / f t\rangle$ & type & $\langle w / f \tau\rangle$ & Pipe & Valve & supp & (in) & Haint & tainal & a Mean $T$ & $\langle A / f t\rangle$ & $(K H / f t)$ & $(f t)$ & $(f t)$ & sets \\
\hline 1 & 0.50 & 0.5 & 3.5 & SETVI=CT & 5.6 & 1.0 & 0.0 & 0.0 & 0 & 27 & 120 & 0.2830 & 0.097 & 0,0063 & 30 & 30 & 1 \\
\hline
\end{tabular}

Notes:

Data used in this design assumes that pipo supports are thermally insulated from the pipos; therefore, no hesting cabte is ineludod for traciny supports. Raychem recommends that you verify the correcthelis ef shis asaumption as pipe supports often cause sulstantial heat losses which should be compensated by heas traeing.

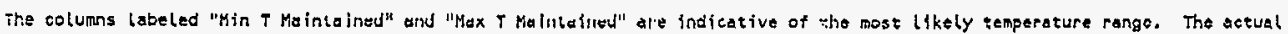
rango will vary dependitig on inaulation thermal conductivity, pipe lecazion, wind speed, and other detelis of the opecific installatien. For lemperature-sensitive applications, use the temperature range indleated to determine if thermestatic control ib Arivitahla.

To aid alectrical desfgn. Trocecole providea electrical circuit load estimates based on the total hesting cable langth. However,

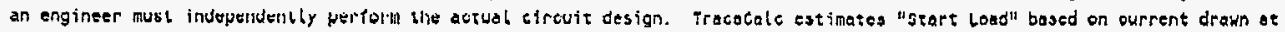
scart-up temperature. Tracecalv estinales ihe verating load ("Oper Load") besed on power output at maintein temperature. for detalled gizing information, consult the Rayehem Electrleal prosection sulletin sp contact your Reycheal representativa.

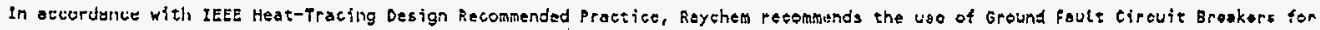
wiping systeals in elassitiad orcas requirling o high degree of maintenance, or which tray be expoced to physical abue or corrogive Armospheres.

Alb of the information contained lin the prestrath or designs produced by it ore be, ieved to be reliable. however, usere ehould

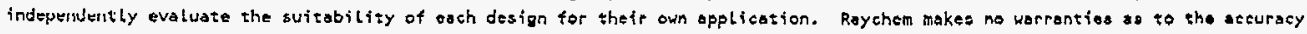
or completuress of the information, and disclajms any lisbility regarding its us:. Raychem's only obligations are those in she stalydard Terms and conditions of sole for this produet ard other products, and in no catt will kaychem be biable for any incidental, indirect, or conaequential damages arising from its sale, resole, ues, or miauso.

HNF-2488, Rev. 0

Page A-47 
Project Name: FLEX

DONE FOT: DICK GRABER

DONE BY: RUSS SUTTER

Des?gh Name: PLEX

Project 1D: ICEKAI

Degign 1D: 1CFKA?

LInes 10: ICFKAI

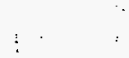

Tomperatureir '

Haintain: $40 \mathrm{~F}$

Min Ambiene: $-20 \mathrm{~F}$

: Hax Ambient: $110 \mathrm{r}$

Mean: $10 \mathrm{r}$

$\therefore$ Process Oper: 40 \%

$\therefore$ Hax Htr Exp: 150 F Eystem Limis: 150 F startup: -20 F

\section{InEulation: GLASS FIBER \\ (ASTH C547-77) \\ $K$ factor ut 50 F: 0.2497 atu-in/hr ftz $r$}

Apes Classificetion code: Ordinary chamicel txpesure Lode: severe Hoat Loss Safety Factor: $10 x$

pipe length per nuppore: 20 it Albew spiralling: No ALlow Uncontrolled; Yas

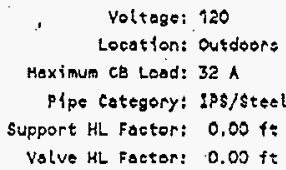

HL output Heater $\#$ stare oper

Fipe Inoul pipe

Size Thick Length \# \# Hoter

Trace Rato Rate Length Comp lood losd

Ref

(in) (in) (fe) valve support Type

H Line No

Ratio (H/ft) (W/ft)

(ft) sets (Amp) (kVA)

commens

$0.50 \quad 0.5$

1 FLEX

0.50

$0.5 \quad 30.0$

-

9 SeTVI-CT

Nores:

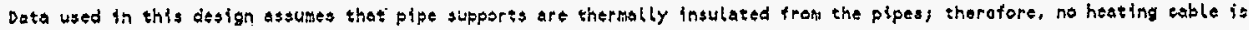

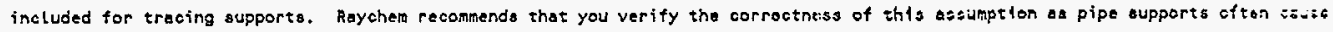
substanzial heet losses which should be compensaced by heat tracing.

To aid eloctrical dosign, Tracelale provides eloctrical cirevit lood est1antes hased on ehe tosal heating cable longth. Hokever, an anginete must independently perform the actuat eireuiz design. Trasecale estimates "Start Lood" bofed on eurrent draun at start-up temperature i Traeccale estimates the operating loof ("Oper Lood") bascd on power output at matitain temperature. For

setalled sizing infermation, consult she kayehen Electrical pretection Bullotin or contect your Rayehen repretentative. $\because \because$

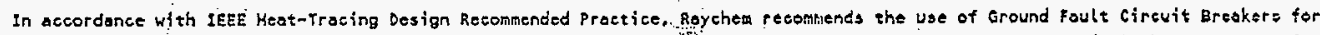
piping systems in elassified aross requiring a high dogreo of maintenance, or which may be exposed to phyaical abuse or corresive stmocpheret.

All of the informetion contalned in the progrom or designs produced by is are believed to be rolitable. However, ueare ahould independenty eveluate she suitobitisy of eaeh desigh for their own epplicetion, Raychelt makes no warrantios as to the aceuracy. or completoness of the information, and disctaims ony lieblitty regarding its vie. Raychem's only obligationt are those in the standard Terms and conditions of sole for this product and other producss, and in no ease will naychem be liable for any incidental, indirect, or consequential damagea arising from its oblo, rosole, uze, or misuse.

HNF-2488, Rev. 0

Page A-48 
RAYGHEM

chemelex Division
Project Nane: FLEX

DOME FOY: DICK GRABER

DONE BY: RUSS SUTTER

Design Name: FLEX

FPOJEE: 10: ICFKAT

Design ID: ICFKAI

bines 10: ICFKA!

Startup: $-20 \mathrm{~F}$

DS Pipe insul Hit

Ref Size Thick Rate Heoter

\# (in) (in) $(H / f \varepsilon)$ Type

$\begin{array}{llll}0.50 & 0.5 & 2.9 & \text { 3вTV1-CT }\end{array}$

Tomporaturas
Kaintain: $40 \mathrm{~F}$
Hin Ambient: $-20 \mathrm{~F}$
Max Aabient: $110 \mathrm{~F}$
Hean: $10 \mathrm{~F}$
Process Opers $40 \mathrm{~F}$
Hax Htr Exp: $150 \mathrm{~F}$
System Limlt: $150 \mathrm{~F}$
Startup: $-20 \mathrm{~F}$

Output rect of lleater

Rate /ft per per pisch

(W/fq) Plpe valve supp

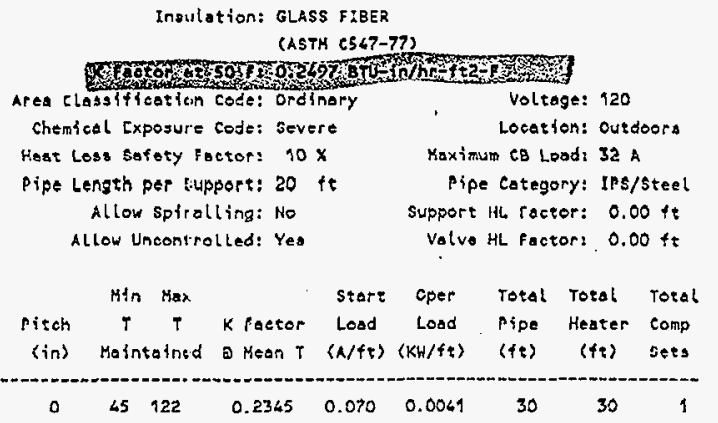

Notes:

Data used in this design assumes that pipe supports are thermalty insulated fron. the pipes; therefore, no hoating zable is irefuded for treeing upports. Rayehem recommends that yeu verify the correctness of this ossumption as pipe supports often ceuse substantial hear losses which should be componsatod by heat tracing.

The columm labeled "Win $T$ Maintained" and "Max $T$ Maintelned" ore indfeative of the mose likely temperature rango. Tho actual range will vary depending on insulation thernol conduetivity, pipe locetion, wird speed, ond ether details of the speeifie installation. For temperature-sensitive epplications, use the temperature range indiested to determine if thermestatic controb is edvisable.

To aid elettrical design, Tracetole provides electrical tircuit load estimatea kased on she total hooting cable length. However, an engineer must independently perform the attual eiteuit design. Tracecole estimates "start Load" basod on eurrent drann at start-up temperature. Tracecala est\{mates the operating lood ("Oper Load") based on poiker output at maintain tompereture, For detailed sizing information, consule the Rayshem Eiectrical protection bullotin or contact your fayshem representative.

In accordance yith IEEE Hest-Tresing Design Recommened Prattice, Reychem recomnts the use of Ground fault Circuit Breakers for piping systegs in elassified areas requiring a high degree of maintenance, or which may be exposed so physical abuse or torrosive atmospharas.

All of the information contained in the program or designs produced by it are believed to be reliable. Hotever, ueere ohould independently ovaluate the suitobility of each design for their own application. Rayehem makes no warrantics as to ethe aceursey or complezemess of the information, and disclsims any liability regarding its uso. Raychem's only obligations are thoe in the standard terms and conditioms of sole for this product and otiser products, and in no case will Raychem be liable for any

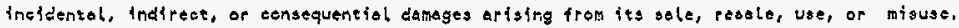

HNF-2488, Rev 0

Page A-49 
Project Name: $N$

Done For: DICK GRABER Done By: RUSS SUTTER

Design Name: FLEX

Projeet 10: ICFKAI

Design ID: ICFKAI

Lines 10: ICFKA2

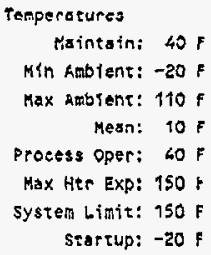

\section{Insuletion: FOAMED ELASTOMER}

(ASTH C534-70) $x$ Factor it 50 r: 0.2933 BTU-in/hr-ft2-F

area thassiffeation code: Ordinary chemical Exposwie code: Severe Het Loss Safoty Fattor: $10 \%$ Pfpe length fer support: $20 \mathrm{ft}$ Allow splralling: No Allow uneonerolles: yes

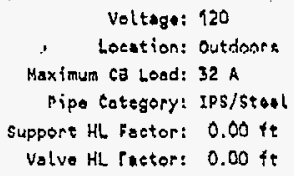

Veltage: 120

Location: Outdones Maximum ce Lead: $32 \mathrm{~A}$

Pip. Catesory: IPS/\$t04l Suppore HL. Factor: $0.00 \mathrm{ft}$ valve HL ruster: $0.00 \mathrm{ft}$

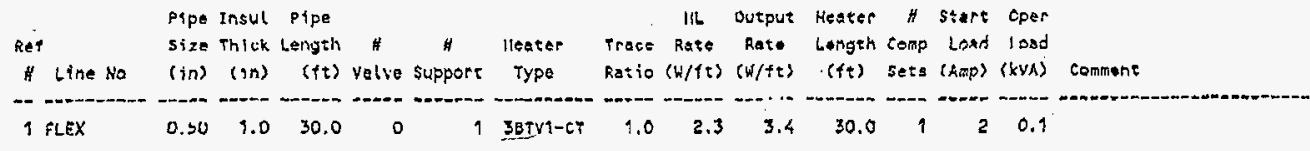

Notes:

Cata used in this design assumes that pipe supports are thermally insulated frem the fipas therefore, no heating eable is included for tracing supports. Raychem recommends that you verily the correctress of this essumption as pipe supports oftan ealite substantial lieat losses which shosid be compensofed by heat troctrig.

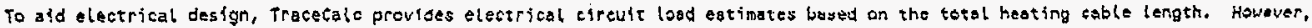
an engineer must incependently perform the atuel circust design. Tracecale vilimazes "start Loedl based on currexe draun at start-up tomperatupe. Tracecale estimates the operating losd ("Oper Load") based ull power output at mo intain terfiperature. Fox darailed gizing information, consult the Rayehea Eleutrical frotection oulletin or centoct your Raychun representative.

In accordance with IEEE Hest-Trasing Design Recomanded Practlce, Raychem recun mends the use of Ground Fauls Circuit Brekkers for piping systems in clagsifted areas requiring a nigh degree of meintensnce, or which tay be exposed to physical abuee or corrofive ntmospheres.

All of the information contained in the progran or cesigns produczed by it are keltsved to be relisble. However, users should independently evaluate the suitabllity of aach design for their own applicaziori, Raychen makes no warparties os to the oceuracy af completeness of the information, and diselaims any liability regseding its lise, Raychen's only obligations are those in the standard Terms and conditions of sale for this product and oxher products, and in no case wlll kayehem be liable for any incidental, indrect, or consoquentlab damages arlsing from iss able, resale, ise, or misuse.

HNF-2488, Rev. 0

Page A-50 


$$
0 .+\operatorname{lgn} s u m m a r y
$$

roject Name: $\$$

Done For: DICK GRABER

DOne 8Y: RUSS SUTTER

Design Name: FLEX

Project ID: ICFKAI

Design ID: ICFKAL

hines 1U: ICFKAI

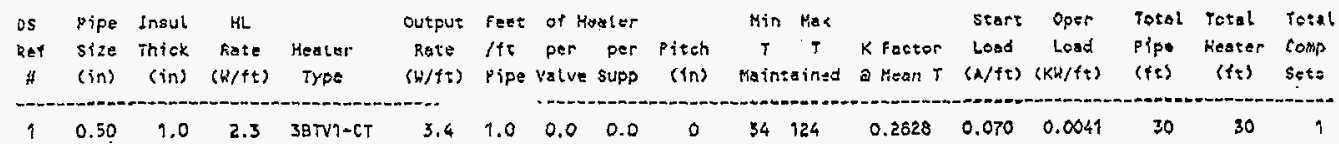

\section{Temperatures Maintain: 40 $r$ \\ Inadlation: FOAMEO ELASTOKER ( $15 \mathrm{TH}$ C53/5-70)} Min Ambient: $-20 \mathrm{~F}$ Max Anbtunt: 110 F Nean: $10 \mathrm{~F}$ Process Oper: 40 F Max Ker Exp: 150 f 5ystem Limik: $150 \mathrm{~F}$ starzup: $-20 \mathrm{~F}$
$K$ Foctor st $50 \mathrm{~F}: 0.2933 \mathrm{BTU}-\mathrm{in} / \mathrm{hr}-\mathrm{ft} 2-\mathrm{F}$ Area classitleotion code: Ordinary chealcal Exposune code; severe Heat loys safecy factor: $10 \%$

Pipu Length per support: $20 \mathrm{ft}$ Allow gof-alling: No Allow Uncontrollod; Yes

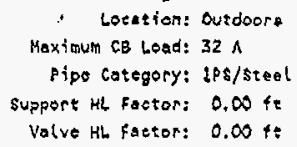

Notos:

dara used in this design assutuss that pipe supports are thermally insulasod fron the piftei shorofore, no heating cable it included for tracing supports. Raychem revoulliends that you verify the correctness of this aseumption as pipe tupports often anke substurlital heat losses which should be compensated by hest trocing.

The columns labeled "Min I maintained" and "Max T Maintained" are indlective of the most likely semperature range. The ectual range will vary depending on insulation shermal conductivity, pipe lotation, wiad speed, and osher derails of the spocific installation. For semperaturo-sensitive applieations, use the semperaturo rang indicated to determine if thermostatic control is advisable.

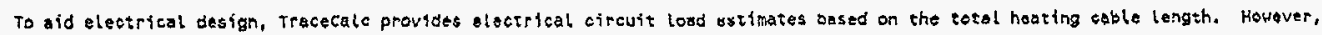
an enginear must independently perform the actuat eiroutt design. Tracetals estimates "gtart boad" based on eurrent drawn at start-up temperature. Tracecalc estimates lhe operating load ("oper load") bosod on power owsput at malntein temperatiara. For detalled sizing intormotion, consult the kaychen Electrical protection bulletin or contect your Raychem roprasensative.

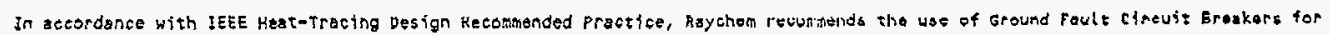
piping systems in classified areas reguiring a high degres of mainituance, or whish may be exposod to physical abuse or corrosive atmospheres.

All of the informstion contained in the progran or designs produced by it are telieved to be reliable. Howevar, ucere should

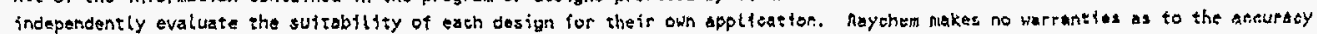
or comploteriess of the information, and disclaims any labiltiy regarding lis lise. Raychen's enly obligazlone are those in efte standard terms and condizions of sele for this product and oxher products, and in no ceso will Rayehem bo liable for any incidental, indirect, or consqguential danages artaing from its sole, rasole, too, or misuse.

HNF-2488, Rev. 0

Page A-51 
HNF-2488, Rev. 0

W320-31-015

Cable Ampacity, Lighting, Conduit Fill, \& Voltage Drop 
This sheet shows the status and description of the attached Design Analysis sheets.
Discipline Electrical
wo/Job No. ER4319
Calculation No. W320-31-015

Project No. \& Name W-320 TANK 241-C-106 WASTE RETRIEVAL

Calculation Item Cable Ampacity, Lighting, Conductor FiTl, \& Voltage Drop

These calculations apply to:

Dwg. No. H-2-818677 Elect Service Building Details Rev. No. 0

Dwg. No. H-2-818430 241-C-106 Raw Water System Plan Rev. No. 0

Other (Study, COR) KGS-94-009 Project 93L-EW-320, Tank 241-C-106 Rev. No. NA

Sluicing, Letter of Instruction, Definitive Design, Revision 6

dated April 1, 1994

Functional Design Criteria for Tank 241-C-106 Waste Retrieva1.

Project $W-320$, Revision 2

The status of these calculations is:

[] Preliminary Calculations

$[X]$ Final Calculations

[] Check Calculations (On Calculation Dated)

[] Void Calculation (Reason Voided)

Incorporated in Final Drawings?

[X] Yes [] No

Calculation verified by independent "check" calculations? [] Yes $[X]$ No

Original and Revised Calculation Approvals:

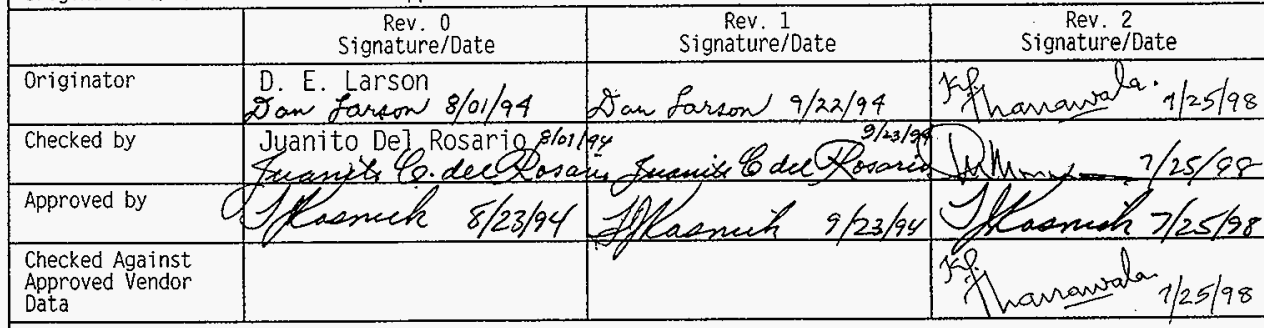

Design

Analysis

Page No.

INDEX

\begin{tabular}{|c|l|}
\hline$i$ & Calculation Identification and Index \\
\hline$i i$ & Calculation Cross Index \\
\hline 1 & Objective; Design Inputs; Criteria and Source; Assumptions \\
\hline 2 & Methods to be Used \\
\hline 2 & References \\
\hline $4-8$ & Calculation \\
\hline 8 & Findings and Conclusions $\quad$ HNF-2488, Rev. 0 \\
\hline
\end{tabular}

KEH $0378.00(06 / 92) \quad$ KEF072 


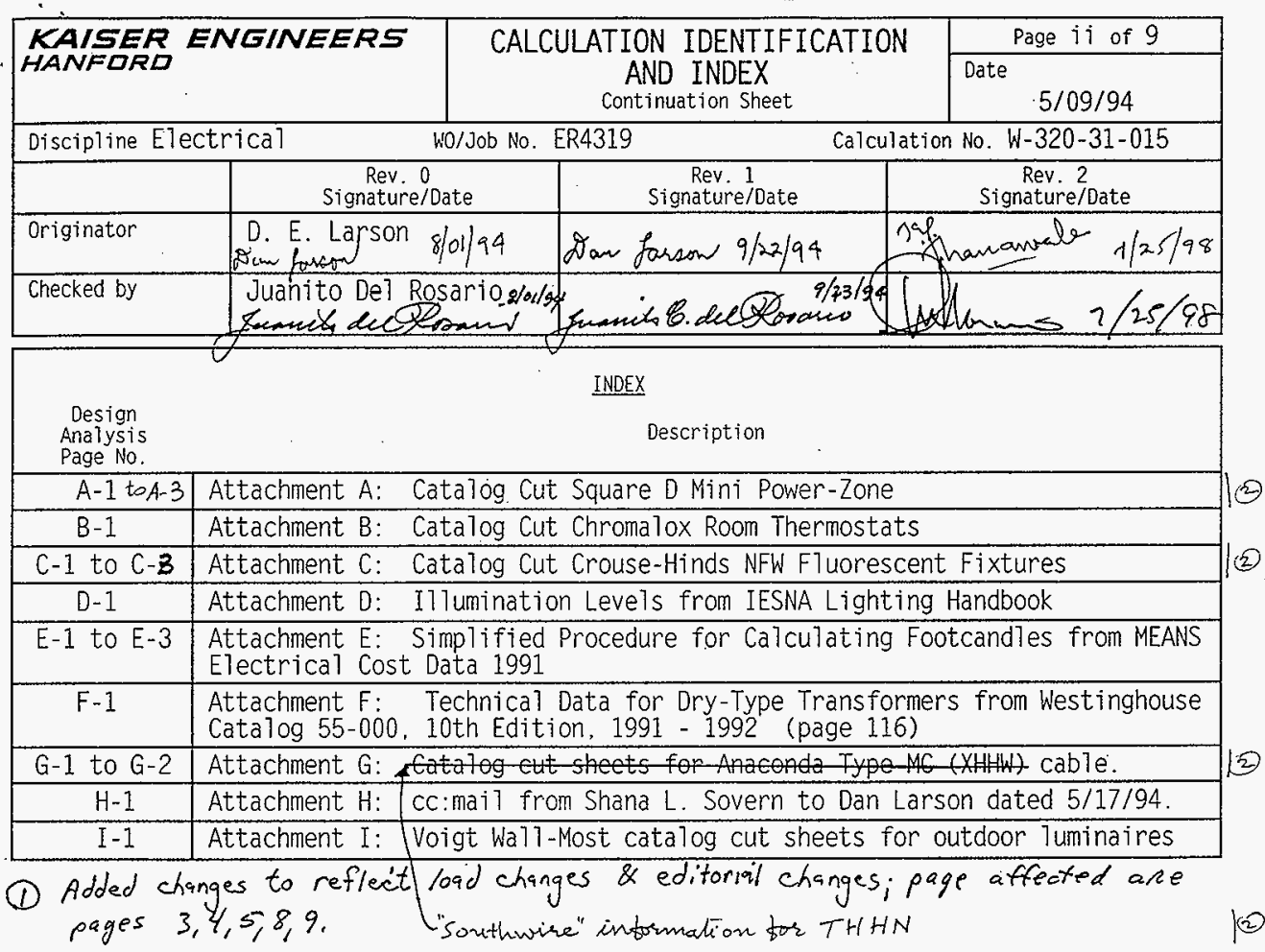

\begin{tabular}{|c|c|}
\hline$J-1$ to $J-4$ & Attachment $J$ : "Chromalox" wall monuted convection Heater \\
\hline$k-1$ to $k-4$ & Attachment K: "ACME" Centrimaster Wall Exhausters \\
\hline$L-1$ to $L-2$ & Attadument L: "VANAIR" Heathess Regenverative Derger \\
\hline$M-1$ to $M-4$ & Altachment M: "INGER SOLL RAND" Air Compresseses \\
\hline
\end{tabular}

(2) General Revision as shown.

HNF-2488, Rev. 0

Page B-2 


\section{DESIGN ANALYSIS}

Client WHC

Subject Service Building Installation

Location Tank Farm C
W0/Job No. ER4319

Date $8 / 01 / 94$

Checked $8 / 0194$

By D.E. Larson

By J. Del Rosario

\subsection{OBJECTIVE}

The objective of this calculation is:

a. To size and select a Mini-Power Zone.

b. To size and select the main feeder cables that supply the service building loads. (including the $5, \mathrm{HP}$ air compressor)

$$
1 \frac{1}{2} \text { and }
$$

c. To size and select branch/feeder cables.

d. To size conduits for fill.

e. To verify lighting fixtures for proper illumination levels

f. To calculate voltage drops, including during air compressor motor starting.

\subsection{DESIGN INPUTS}

a. KGS-94-009 Project 93L-EW-320. Tank 241-C-106 Sluicing, Letter of Instruction, Definitive Design. Revision 6 dated Apri1 1, 1994

b. NFPA-70, National Electrical Code, 1993.

3.0 CRITERIA AND SOURCE

Functional Design Criteria for Tank 241-C-106 Waste Retrieva], Project W-320, Revision 2

\subsection{ASSUMPTIONS}

a.-Power is stpplied initially from the Power Distribution Panel (C-PDP-1) andlater from-an MCC, NH.

b. All conductors are stranded copper rated for $90^{\circ} \mathrm{C}\left(194^{\circ} \mathrm{F}\right), 600 \mathrm{~V}$ insulated

c. Ambient temperature inside building is considered to be $46^{\circ} \mathrm{C}\left(115^{\circ} \mathrm{F}\right)$ for worst case condition. Temperature outside of the building is considered to be $46^{\circ} \mathrm{C}$ $\left(115^{\circ} \mathrm{F}\right)$ the same for worst case condition.

d. A11 conductors are assumed to be routed in rigid steel conduit or EMT.

e. Electrical loads are listed later in this calculation. In the absence of manufacturer's information. values from the 1993 NEC are used.

f. Assume reflectances of $80 \%$ for the ceiling and $50 \%$ for the walls. 
DESIGN ANALYSIS

Client WHC

Subject Service Building Installation Location Tank Farm C
Revision $\theta 2$

Page No. 2 of 9
WO/Job No. ER4319

Date $8 / 01 / 94$

By D.E. Larson D.E.L. Checked \&lor'or

By J. Del Rosarto Revised AA 1/25/98 By HA KP Thanawala.

g. Short circuit calculation need not be considered. The basis for this is that preliminary calculations have shown low fault values.

h. Emergency lighting is not necessary. The building is small and largely unoccupied.

i. Illumination levels within the Service Building are needed for performance of visual tasks of high contrast or large size. Assume .9 maintenance factor (MF).

j. Power Factor is assumed to be .85 .

k. Air compressor KVA/HP is class G

1. Motors may be assumed to be 1 KVA/HP.

\subsection{METHODS TO BE USED}

\subsection{CABLE, PANELBOARD AND CIRCUIT BREAKER SIZING}

a. Determine maximum rated load of each component (receptacles, lights, and misc. equipment).

b. Determine maximum load on Mini-Power Zone.

c. Select cables and circuit breakers.

d. Derate cable ampacities for ambient temperature.

\subsection{LIGHTING REQUIREMENTS AND FIXTURE SELECTION}

a. Lighting requirements are from the Illumination Engineering Society of North America. IESNA. Simplified method of calculation from Means cost Data is used to calculate light intensities.

\subsection{CONDUIT FILL AND VOLTAGE DROP}

a. Application of NEC tables and application of ohm's law

\subsection{REFERENCES}
a. National Electrich Code (1993)
b. Lighting Handbook 8th Edition - Illumination Engineering Society of North America (IESNA)
c. NEMA MG 1- 1993 Motors and Generators
d. Westinghouse Lighting Handbook 
KAISER ENGINEERS HANFORD

\section{DESIGN ANALYSIS}

Client WHC

Subject Service Building Installation

Location Tank Farm C
Calc. No. W320-31-015

Revision $\theta 2$

Page No. 3 of 9

Wo/Job No. ER4319

Date $8 / 01 / 94$

By D.E. Larson D.E.L.

Checked 8/01/94

By J. Del Rosarigrese

Revised HA 7/25/98 By HA KPThanawala.

\subsection{CALCULATION}

\subsection{LOADING WITHIN THE SERVICE BUILOING}

\subsubsection{Total Load}

Two duplex receptacles

Electric Heater

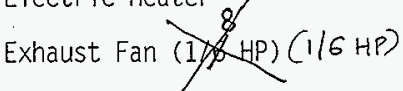

Two fluorescent fixtures

Outdoor fixture
$2 \times 180=360 \mathrm{VA}$

2,0001000 VA

$-139-528 \times A 528$ VA

200 VA

60 VA
SUBTOTAL

Air Dryer (future-7oad) (200 $\mathrm{mA}$ )

so solenoid valve (future load)

SUBTOTAL

\section{$3172-2789$ र्टण्ण VA}

Select a Mini-Power Zone of size 5000 VA. This will provide acceptable margin of $56 \%$ for unanticipated future loads. Additional margin is available because the exhaust fan should not be operating at the same time as the heater. The total load must include the load of the air compressor. This $\not, H P$ motor may be assumed as drawing 7.6 amps as shown in NEC table $430-150$

$$
11.0 \quad 11.0
$$

$V A=V \times A \times 1.732=480 \times 7.6 \times 1.732=.6318 \mathrm{VA} 914.5 \mathrm{VA}$

This brings the total load to:

TOTAL

\section{$12317 \stackrel{+107}{8526} \mathrm{VA}$}

\subsection{Mini-Power Zonie Over-Current Protection}

Mini-Power Zone rated 5 kVA with 2 pole primary main circuit breaker with rating of 20 Amps a 480 volts $A C$ and secondary 2 pole main circuit breaker of 30 Amps at 240 volts AC (see Attachment A) will supply 2208 VA (44\%) plus 56 $\%$ capacity for future expansion.
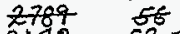

$3172 \quad 63.5$ 


\section{KAISER ENGINEERS}

HANFDRD

Client WHC

\section{DESIGN ANALYSIS}

Subject Service Building Installation

Location Tank Farm C
Calc. No. W320-31-015

Revision \& 2

Page No. 4 of 9

wo/Job No. ER4319

Date $8 / 01 / 94$ By D.E. Larson D.E.L.

Checked 8loylat By J. Del Rosarigere

Revised HA 7/25/98 By HA KP Thanawala.

Secondary fulT load current $=5000$ KVA $/ 240 \mathrm{~V}=20.83 \mathrm{~A}$

$1.25 \times \mathrm{Sec}$. full load current $=26$ Amps [NEC ART. 450-3]

Manufacturer's standard breaker of 30 amps is next higher rating.

The maximum primary current through the Mini-Power Zone is:

$$
I=V A / V=5000 / 480=10.42 \text { amps }
$$

The manufacturer's standard for the Primary breaker rating is $20 \mathrm{~A}$. This will coordinate with the secondary breaker and handle the full load rating of the MiniPower Zone.

The largest load is the electric heater. This will draw the most current:

$$
\begin{aligned}
& I=W / V=1000 \text { watts } / 120 \text { volts }=8.3 \text { amps. } \times 1.25=20.815 \mathrm{~A}[\mathrm{NEC} 424-3(\mathrm{k})] \\
& \text { all }
\end{aligned}
$$

Industry standard circuit breakers of $20 \mathrm{~A}$ shall be used for ${ }^{\wedge}$ branch circuits, except

\{They wilT be satisfactory for any of the proposed loads.

the electric heater branch circuit which shall require a 25 imp bresker per NEC 384-16(c).

7.3 Feeder and Cable Selection

7.3.1 Supply Cable setection: A minimum size of \#12 AWG

feeder cable is selecte to supply the Service

Building from the Power Distribution Panel to satisfy Air Compressor and

MPZ 20 A panel rating. Full load current at the

primary of the Mini-Power Zone and the air compressor

is:

Mini Power Center: $I=V A / V=5,000 / 480=10.4$ amperes

Air Compressor: $\quad I=71.0$ amperes (from NEC table 430-150)

21.4

The total current is then the sum or 18 amperes.

For cable gizing: $\frac{T}{T}=1.25 \times 11.0+10.4=24.15$ amps. 40

The ampacity of \#12 ÄWG cable from NEC table $310-16$ is $30 \mathrm{~A}\left(90^{\circ} \mathrm{C}\right.$

rating). This ampacity is derated for the ambient condition

$I=.82 * \frac{30}{40}=\frac{24.6}{32.8}$ amps

It is not known what the rating of the terminations are at the Power Distribution Panel supplying the Service building. It must be assumed that they are 


\section{KAISER ENEINEERS \\ HANFDRD}

\section{DESIGN ANALYSIS}

Client WHC

Subject Service Building Installation

Location Tank Farm C
Calc. No. W320-31-015

Revision $\& 2$

Page No. 5 of 9
WO/Job No. ER4319

Date $8 / 01 / 94$

Checked s6/194

Revised 7/25/98
By D.E. Larson D.E.L.

By J. Del Rosarigrze

only rated for $60^{\circ} \mathrm{C}$ rise. Per NEC article 110-14(C)

Exception No. 1:

Conductors with higher temperature ratings shall be used, provided the ampacity of such conductors is determined based on the $60^{\circ} \mathrm{C}\left(140^{\circ} \mathrm{F}\right)$ ampacity of the conductor size provided.

Per conversations with Hanford Code experts. Attachment $H$, the derating for terminations need not be considered along with derating for high ambient conditions. They are to be treated separately. The $60^{\circ} \mathrm{C}$ rating of $\# 12$ AWG wire is 20 amperes, this will carry the full load of the Mini Power Zone solthis satisfies the termination derating.

10

30

7.3.2 Branch Cable Selection: The largest anticipated load to be supplied from the Mini-Power Zone is a $1 \mathrm{~kW}$ heater. This is the worst case for normal branch circuit ampacity. This wil1 draw:

$$
I=V A / V=\stackrel{2}{Z} 000 / 120=\frac{16.7}{8.33} \mathrm{amps} \times 1.25=20.875 \mathrm{amps}
$$

Select \#12 AWG for branch circuits. Branch circuits wi11 be protected by $20 \mathrm{~A}$ circuit breakers with exception of heater branch circuit which requires a $25 \mathrm{~A}$ circuit brcaker, and \#10 AWG cable, per NEC table 310-16. The ampacity of \#12 AWG cable from NEC table $310-16$ is $30 \mathrm{~A}\left(90^{\circ} \mathrm{C}\right.$ rating). This ampacity is derated for the $120^{\circ} \mathrm{F}$ ambient temperature condition:

$I=.82 * 30=24.6$ amps

assumed that

It is $k$ wat the rating of the terminations at each device-As-above, it must be assumed that they are oniy rated for $60^{\circ}$ $C$ rise. The $60^{\circ} \mathrm{C}$ rating of the $\# 12$ AWG cable is 25 amperes. This is adequate ampacity for the branch circuits.

7.4 MOTOR CONTROL

There are two motors to be considered. The first is a $\mathrm{HP}$ (exhaust fan motor. Per NEC table 430-148, the full load motor current is 4.4 amps It is intended that the Mini-Power-Zone circuit breaker supplying the motor serves as means of disconnect and that the thermostat serve as the controller. This will be within line of sight satisfying NEC 430-102. Per NEC 430-109, it is acceptable to use a circuit breaker as a disconnect for a $1 / 6 \mathrm{HP}$ motor provided $i$ ts rating is not less than twice the full load rating of the motor. thê curcuit brke $I_{B}=2 \times I_{M}=2 \times 4.4=8.8$ amps

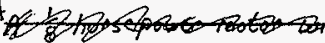

KEH $0037.00(06 / 92)$ KEF055
HNF-2488, Rev. 0

DEL $9 / 22 / 94 \quad \frac{k p 9}{(7 / 25 / 98)}$

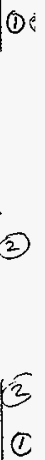




\section{KAISER ENGINEERS} HANFORD

DESIGN ANALYSIS

Client WHC.

Subject Service Building Installation

Location Tank Farm C
Calc. No. W320-31-015

Revision $\otimes 2$

Page No. 6 of 9
W0/Job No. ER4319

Date $8 / 01 / 94$

By D.E. Larson D.E.L,

Checked 8/4/94

Revised HA1/25/98
By J. Del Rosario fese

By AA KP Thanawale.

The circuit breaker is rated at 20 amps. $20>8.8$ It is acceptable to use a circuit breaker as a disconnect.

Per NEC 430-110, the ampere rating of motor interrupting means (thermostat) sha11 have $115 \%$ the full load rating of the motor. 1.15 $\times 4.4=5.06$ amps The selected thermostat has a rating of 25 amps. (See Attachment B) $25>5.06$. It is acceptable to use the thermostat as a motor interrupting means. $7 \frac{1}{2}$

The second motor is the future. 5 HP air compressor packaged unit. Control for this motor will be supplied by the compressor vendor.

condrit

7.5 onductor $\mathrm{Fi} 11$

$3 B$

10

Branch Circuits: Per NEC Chapter 9 Table $3 A$ we can have up to 7 \# 12 or 6 \# 10 THHN Conductors in a $1 / 2$ " conduit. Inspection of the drawings shows that we have no more than 4 conductors in any of our EMT conduits.

Supply Circuit: Per NEC Chapter 9 Table $3 B$, we can have 17 \#8 inG 10 and 18.36 \# 10 AWG in an $1^{\prime \prime}, 5^{\prime \prime}$ conduit. 10 There is - a possibility the supply wi11 be a 48 conductors \#8 AWG type fable. This will have a cross-sectional area of.04tz square inches. Hur (See Attachment G)

therent with this - cable-is an inherent $\$ 10$-Alf ground conductor. The total area taken up by the cable is 62 square inches. 0.091

Per NEC table 4 one not lead covered cable can be up

0.21 to 7.08 square inches and sti 17 not exceed the $-5.3 \%$

fi 117 requirement.

0.210 .091

or $1.08>.637$ square inches

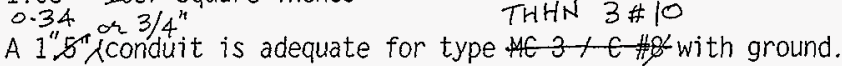

$3 / 4$ "condruit and 0.34 so.in. in 1" condmit,

7.6 LIGHTING

Inside Lighting: Per IES (Attachment D), average of 30 footcandles is . adequate. The Zonal-Cavity Method wi11 be used to determine the number of fixtures.

Room Cavity Ratio $(R C R)=[5 \times h \times(L+W)] /(L \times W)$

$h=$ height of 7 ight

$L=$ room length

$W=$ room width

$R C R=[5 \times 8 \times(10+8.5)] /(10 \times 8.5)=8.7$ 


\section{DESIGN ANALYSIS}

Client WHC

Subject Service Building Installation
Revision $\theta \sim$

Page No. 7 of 9

Wo/Job No. ER4319

Date $8 / 01 / 94$

By D.E. Larson D.E.L.

Checked 8/01/54 By J. Del Rosarigfex Revised AA-T/2s/98 By KA KP Thamauralo.

Using the Crouse-Hinds photometric data (Attachment

C). with an assumed ceiling reflectance of $80 \%$ and

an assumed wall reflectance of $50 \%$, the coefficient

of utilization is 25.28

$\#$ of fixtures $=\left(F C \times F^{2}\right) /(\#$ of lamps $\times$ lumens/lamp $\times$ CU $\times$ MF)

\# of fixtures $=(30 \times 10 \times 8.5) /(2 \times 3200 \times .25 \times .9)=1.771 .58$

Use two fixtures.

Entrance 7 ighting needs 3 footcandies. Total area

that needs to be 7 it is approximately $6^{\prime} \times 3^{\prime}=18 \mathrm{ft}^{2}$

The fixture selected for outdoor use is the voigt

SOX-35 Wa71-Most. The manufacturer's data in

Attachment I may be used to determine whether this

fixture is adequate for our needs. The Footcandle

Isolux diagram shows the footcandles available from a

Voigt SOX-55 at a height of $15 \mathrm{ft}$. This must be adjusted to obtain values for the sox-35 at 10 feet.

To adjust for the lower lamp output, the footcandles will be multiplied by .6. This is obtained from the ratio of the lumen output of the lamps. The Westinghouse lighting handbook provides guidance for adjusting for the height difference. The following is quoted from page 2-14 of the 1969 . Westinghouse lighting handbook. "Footcandles for other mounting heights than the one shown are obtained by multiplying the values given on the curves by the ratio of the square of the present mounting height to the square of the new mounting height."

This adjustment factor wi 11 be $\left(15^{2} / 10^{2}\right)=2.25$

We will consider an area $3 \mathrm{ft}$ out from the wal1. The chart shows this as approximately 7 footcandles.

HNF-2488, Rev. 0

Page B-9

2009 $(7 / 24 / 98)$ 


\section{KAISER ENGINEERS HANFORD}

DESIGN ANALYSIS

Client WHC

Subject Service Building Installation

Location Tank Farm C
Calc. No. W320-31-015

Revision $\mathrm{O}^{2}$

Page No. 8 of 9

Wo/Job No. ER4319

Date 8/01/94 By D.E. Larson D.E.L.

Checked slals4 By J. DeT Rosarigsax

Revised HA 1/25/98 By HAKP Thanawale.

Using our adjustment factors this becomes:

7 footcandles $\times 2.25 \times .6=9.5$ footcandles

Outdoor fixtures will give adequate light.

7

7.7.8 Voltage Drop

From the Power Distribution Panel (PDP) to the Service building is approximately $55 \mathrm{ft}$. The voltage drop to the load is divided into three foup parts. These are the voltage drop from the PDP supply to the main disconnect, the voltage drop across the transformer, the voltage drop across branch circuit wiring to the load and the starting voltage drop when the compressor starts.

10

Supply cables are Using conductor

information from NEC Chapt. 9 Table 9:

(55 ft $\times 1.1$ ohms $/ 1000 \mathrm{ft}=.0605$

$$
1821.4
$$

Ful1 load amps are 16.41 amps for air compressor and the mini power zone. (Refer to Section 7.3.1) $.0605+821.4+.81 .295$

Volts dropped $=0935$ ohms $\times 16.41$ amps $=1.53$ volts

$\%$ voltage drop $=(1.53 \mathrm{~V} / 480 \mathrm{~V}) \times 100=\frac{-35.27}{318 \%}$ for $\# 12$ wire

Transformer $Z$ may be assumed to be $2.64 \%$. (see-Attachment F) By definition, this is the voltage drop across our transformer.

Branch circuit conductors can be no longer than $(10 \mathrm{ft}$ length $+8 \mathrm{ft}$ length) with a 20 percent margin. This is a total length of $21.6 \mathrm{ft}$. Per Chapter 9 table 9 the impedance of a \# 12 AwG conductor is 1.7 ohms / $1000 \mathrm{ft}$.

$V=I * Z=20$ amps $\times 21.6 \mathrm{ft} \times 1.7$ ohms $/ 1000 \mathrm{ft}=.7344$ volts

$\%$ Voltage Drop $=.734 \mathrm{~V} / 120 \mathrm{~V} \times 100=.6 \%$ [must be $<3 \%$ ]

Total Voltage Drop $=.278 \%+2.64 \%+.6 \%=3.6-3.51 \% 0.81 \%$ 3.5

Total voltage drop must be less than $5 \%$. $3.6 \%<5 \%$

Voltage drop is satisfactory. 


\section{KAISER ENGINEERS}

HANFDRD

Client WHC

\section{DESIGN ANALYSIS}

Subject Service Building Installation

Location Tank Farm C
Calc. No. W320-31-015

Revision 82

Page No. 9 of 9

WO/Job No. ER4319

Date $8 / 01 / 94$

By D.E. Larson D.E.L.

Checked 8/01/94

By J. Del Rosarigfese

Revised HA1/25/98 By HAKPThanawala.

\section{5}

Upon starting our compressor wi11 draw about 45.6 LRA amps per NEC Table 430-151. In order to start our compressor motor our supply voitage should not dip below $80 \%$ of the motor's voltage rating. This current is in conjunction with the current to our mini-power zone. The total worst case current will then be:(Res. Sec. 7.3.1)

$$
63.574
$$

$10.4+45.6 \approx 56$ amps

Voltage drop to compressor is the drop across our 55 foot \# 12 supply and an additional $20 \mathrm{ft}$ to the compressor motor.

.0 .605744 .477 of 12

$0935 \times 56=5.236$ volts to the disconnect.

$63.5 \times 2.159$

45.6 amps $\times 20 \mathrm{ft} / 1.7 \mathrm{ohms} / 1000 \mathrm{ft}=1.55$ volts

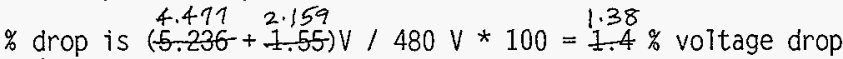

The total 1.38 \%oltage drop is within the allowable limits given for NEMA motors. (NEMA MG-1 12.44.2)

\subsection{FINDINGS AND CONCLUSIONS}

8.1 Supply cable to the Service Building is adequately sized.

8.2 Branch circuit conductors are adequately sized.

8.3 Condrit $f i 17$ is satisfactory.

8.4 Lighting system designed meets or exceeds the minimum required illumination for the $W-320$ Service Building.

8.5 Total voltage drop on air compressor feeder and branch circuit is within tolerance for NEMA motors. 
The Square D Mini Power-Zone ${ }^{\text {i4 }}$ power supply provides the answer to requirements for a portable, compact. package power sup-. ply for small loads. It is suitable for both indoor and outdoor use with its weather-resistant enclosure and sand-epoxy cncapsulated transformer, operating at a maximum full load temperature rise of $115^{\circ} \mathrm{C}$.

All sizes are fumished from warehouse stock with Square D primary and secondary main circuit breakers only, sized in accordance with National Electrical Code requirements.
Feeder circuit breakers are standard Square D, QO plug-on type which may be ordered, as required, from your local Square $D$ distributor's stock. (No tandem breakers permitted.)

Since the Mini Power-Zone is furnished as a complete package. considerable savings in installation time and costs can be realized.

If ground fault protection is required, QWIK-GARD circuit breakers may be used in all sizes except the $5 \mathrm{KVA}$, single phase.

Refer to Bulletin D-IF for more details.

SINGLE PHASE, 480 VOLTS PRIMARY 240:120 VOLTS SECONDARY, $2.5 .0 \%$ TAPS FCBN

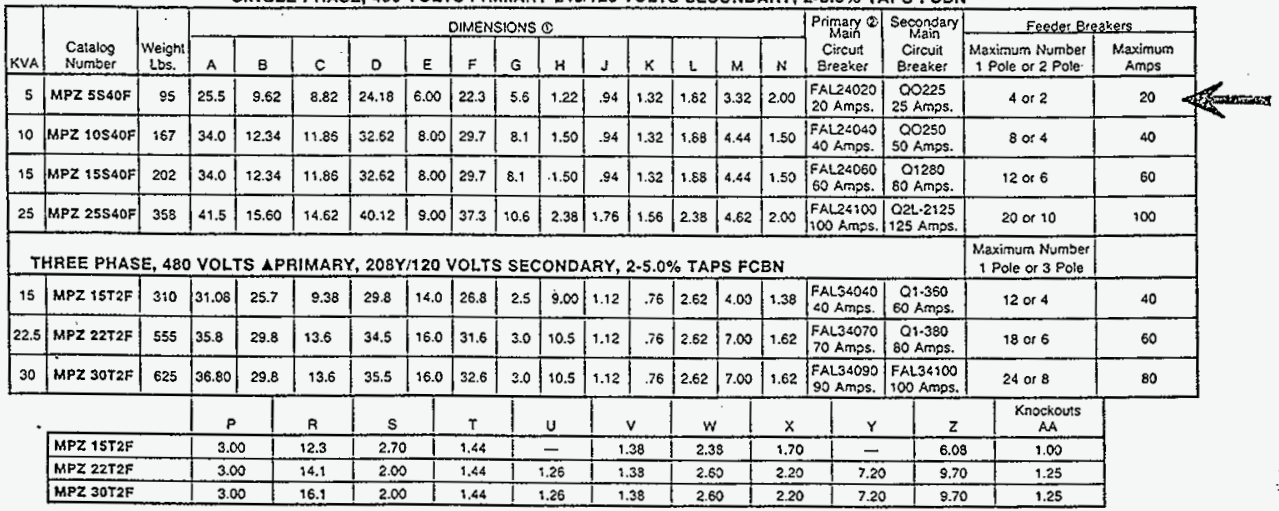

SINGLE PHASE
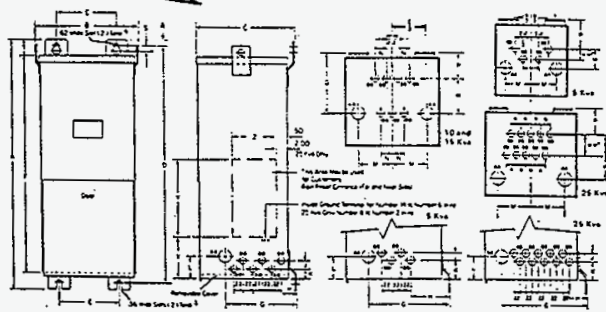

THREE PHASE
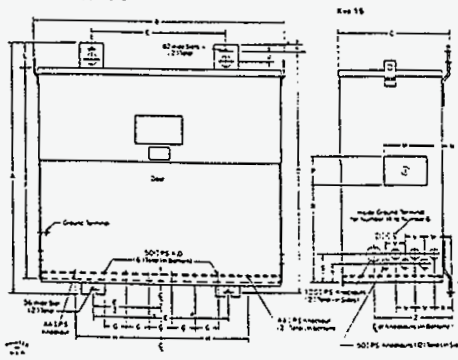

antisunso

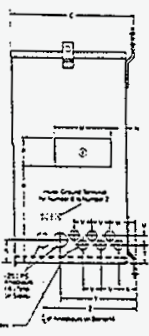

O DO NOT USE FOR CONSTRUCTION; CONTACT SORGEL PLANT FOR CERTIFIED PRINTS.

5. Shunt tio can be provided on primary main ciscrit breaker when required for fire separtment use. No change in dimen. sions. Contact factory or your local SQuare D distributor for price and availablity.

MINI POWER-ZONE - Trademask of Square D Company OWIK-GARD - Fiegistered Tradernarí ol Square o Company $O$ - Registered Tiademetk of \$quare D Company

$$
\begin{gathered}
\text { CALC. W320-31-0!5 } \\
\text { ATTACHMENT:A } \\
\text { WH. } 1 \text { OF } 3
\end{gathered}
$$




HY
\begin{tabular}{|c|c|}
\hline Volts & Line \\
\hline 480 & $\mathrm{H} 1 \cdot \mathrm{H} 4$ \\
456 & $\mathrm{H} 2 \cdot \mathrm{H4}$ \\
432 & $\mathrm{H} \cdot \mathrm{H} 3$ \\
\hline
\end{tabular}

Suitable for use as Service Equipment

5 KVA Maximum Size of Secondary Breaker 20 Amps. (Total eurrent per secondary main bus not to exceed 20 Amps.) If all breaker spaces are utilized. maximum current that can be drawnes through each is 10 Amps.

240 VOLT LINE TO LINE CIRCUIT 120 VOLT CIRCUIT

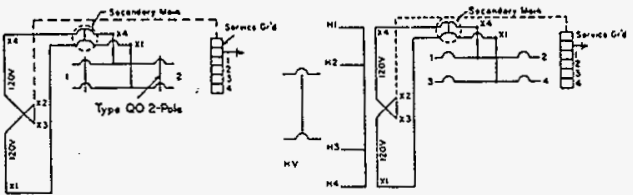

10 KVA Maximum Size of Secondary Breaker 40 Amps. (Total current per secondary main bus not to exced 40 Ampsi) If all breaker spaces are utilized. maxinum current that can be drawn through each is 10 Amps.

240 VOLT LINE TO LINE CIRCUIT 120 VOLT CIRCLIT

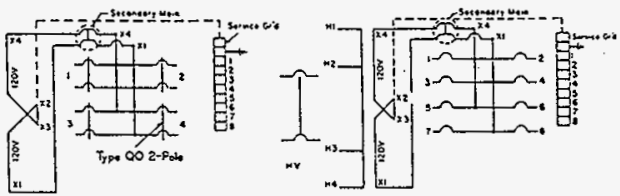

15 KVA Maximum Size of Secondary Breaker 60 Anps. TToul current per secondary majn bus not to exceed 60 Anjps.) If all breaker spaces arc utilized. maxinum current that can be drawn through cach is 10 Amps.

240 VOLT LINE TO LINE CIRCUIT 120 VOLT CIRCLIT
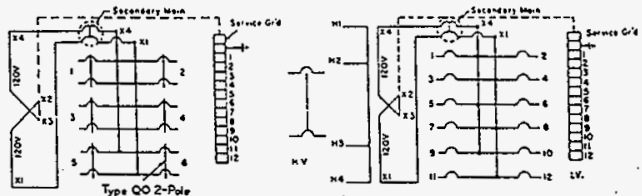

25 KVA Maximum Size of Secondary Brcaker 100 Amps. (Total current per secondary main bus not to exceed 100 Amps.) If all breaker spaces are utilized, maximum current that can be drawn through each is 10 Amps.

240 VOLT LINE TO LINE CIRCUIT 120 VOLT CIRCUIT

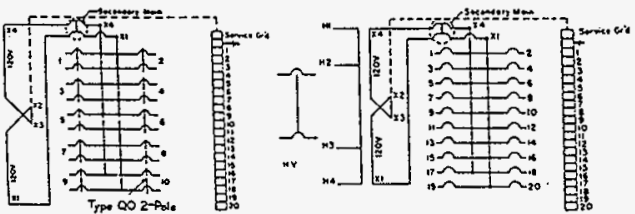

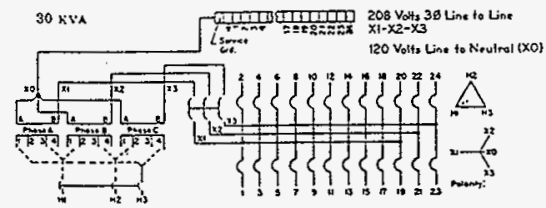

THREE PHASE

\begin{tabular}{|c|c|c|}
\hline Vots & Conn. & Line \\
\hline $\begin{array}{l}480 \\
456 \\
432\end{array}$ & $\begin{array}{l}184 \\
284 \\
28\end{array}$ & $\begin{array}{l}\mathrm{H} 1 \cdot \mathrm{H} 2 \cdot \mathrm{H}_{3} \\
\mathrm{H} 1 \cdot \mathrm{H} 2 \cdot \mathrm{H}_{3} \\
\mathrm{H} 1 \cdot \mathrm{H}_{2} \cdot \mathrm{H}_{3}\end{array}$ \\
\hline
\end{tabular}
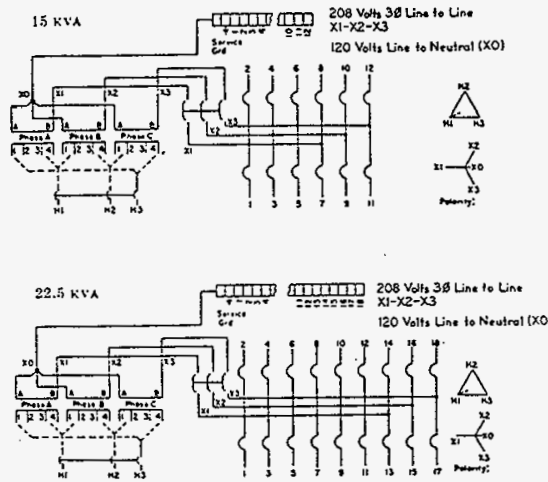

$30 \mathrm{Kr}$
CALC.W $320-31-015$ ATTACHMENT:A

SH. 2 of 3

Nole: Aluminum conductors may be used throughout except on the primary ground le rminal. This is the copper te rminal anached to the case. A copper conductor must be use owith this terminal. 


\section{TYPICAL SPECIFICATIONS}

Fumish and install, as indicated on the electrical plans. Sorgel Mini Power-Zone Dry-Type Package Power Supplies, or approved equal.

Single phase transformers shall be 480 volt primary and $240 / 120$ volt secondary. Three phase transformers shall be 480 volt primary and $208 \% / 120$ volt secondary.

All transformers shall have a minimum of $2-5 \%$ full capacity pri. mary taps below normal and shall be rated $115^{\circ} \mathrm{C}$ temperature rise above $40^{\circ} \mathrm{C}$ maximum ambient. All insulating materials are to be in accordance with curtent NEMA ST20 standards for a $185^{\circ} \mathrm{C}$ UL component recognized insulation sysiem.

Transformers are to be encapsulated using a sand-epoxy resin mixture to provide maximum protection against moisture, dust and corrosive environments.
Package power supplies shall include integrally mounted and wired primary and secondary circuit breakers in accordance with the National Electrical Code requirements.

Branch circuit breakers shall be Square D Type QO or approved equal. All breakers shall be plug-on type. Trip indication shall be clearly shown by the breaker hanole taking a position between $O N$ and OFF when the breaker is tripped and by VISI-TRIPFs indication consisting of a highly visible red tripped circuit indication.

Package power supplies shall be capable of being mounted horizontally or vertically. A hinged access door shall be provided which maintains itself in the open position when desired, and which has padlock provisions to prevent unauthorized entry. All live parts are to be fully enclosed for personnel protection when installation is completed.

All sizes shall be UL. Listed for use as șervice equipment.

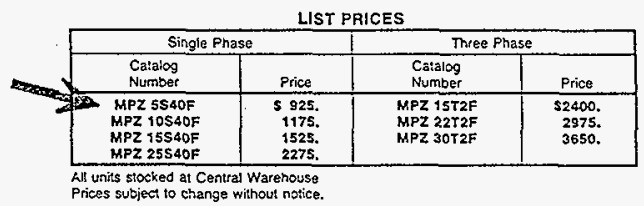

$$
\begin{gathered}
\text { CALCW } 320-31.015 \\
\text { ATTACHMENT:A } \\
\text { SH. } 3 \text { OF. } 3
\end{gathered}
$$

HNF-2488, Rev. 0

Page B-14
SQURRE D EOMPANY D 
HNF-2488, Rev. 0

Page B-15

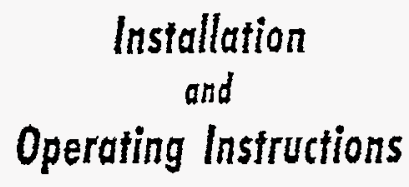

\begin{tabular}{|c|c|c|}
\hline ONV. 4 & SEC. WR & NUHEER $3013 \mathrm{C}$ \\
\hline $\begin{array}{c}\text { SALES } \\
\text { REFEREKLE }\end{array}$ & Supersedes PK435.2] & PK435-3 \\
\hline \multicolumn{3}{|r|}{161.048630 .001} \\
\hline DATE & MAY, 1986 & \\
\hline
\end{tabular}

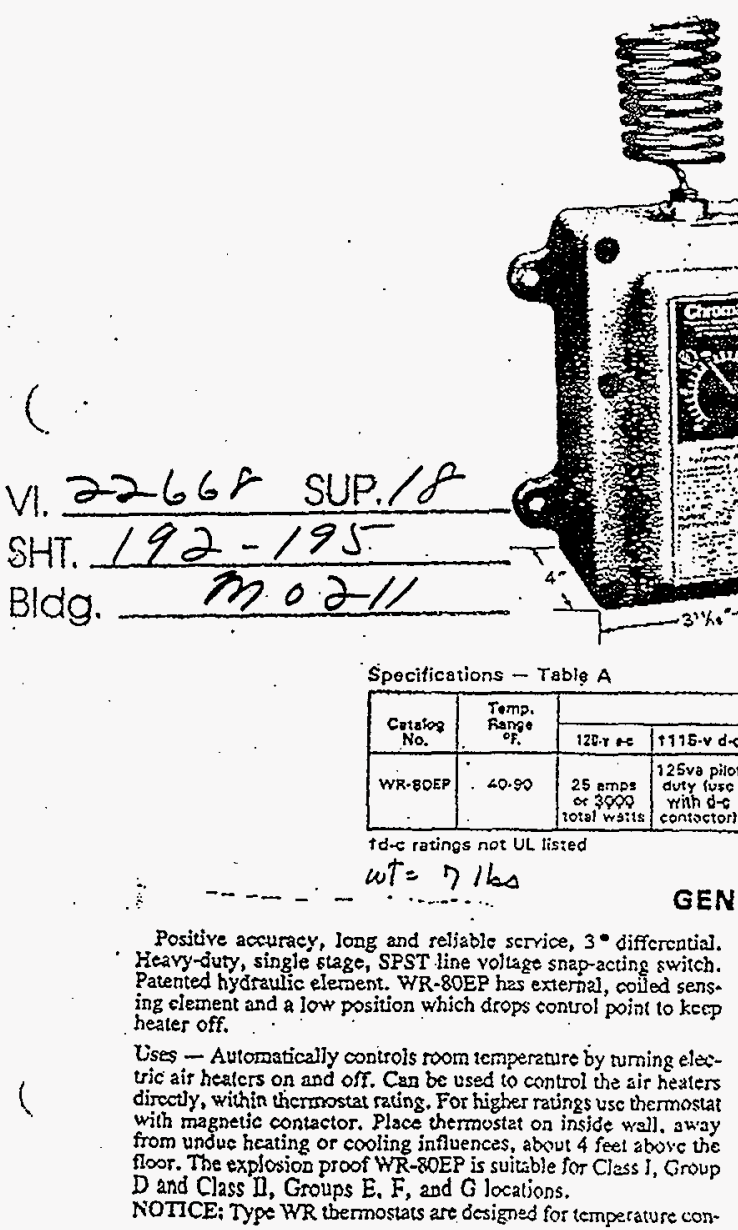

Specifications - Table A

to-c ratings not UL tisted
Positive accuracy, long and reljable scryice, $3^{*}$ differentiaj. Heary-duty, single stage, SPST line voltage snap-acting switch. Patented hydraulic elersent. WR-80EP has external, colled sens. ing element and a low position which drops control point to kcep heater off. dircety within therrit wir whin therrsostat ratins. For higher tatings usc thermostat from unduc heating or coling influences, abut 4 feet alu floor. The explosion proof WR-80EP is suitible for Class I, Group

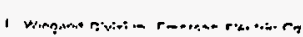

\section{Chromalox Explosion Proof Room Thermostat TYPo WR-80EP}

$$
\begin{gathered}
\text { CALC. N320.31-015 } \\
\text { ATTACHM ENT:B } \\
\text { SH. } 1 \text { OF } 1
\end{gathered}
$$

CEORE:A, ERAIVE, INE. P.O. EOX789 - FICHLAND, WRSH. COISTRACTNO. K-SU20(W3Z0) TRANSWITTAL 130.

YR. SOER

\begin{tabular}{|c|c|c|c|c|c|c|c|}
\hline \multirow{2}{*}{$\begin{array}{l}\text { Catapos } \\
\text { No. }\end{array}$} & \multirow{2}{*}{$\begin{array}{c}\text { Tomp: } \\
\text { Fimpo } \\
\text { कF. }\end{array}$} & \multicolumn{6}{|c|}{ Mexisurn Rationg } \\
\hline & & $125 \cdot r \neq 5$ & $\mid+T 15-\psi d-c$ & $240 . r-c$ & $1230-r d-c$ & $277+4 a-c$ & $480 \cdot Y \mathrm{~B}-\mathrm{C}$ \\
\hline $\begin{array}{c}\text { WR-8OEP } \\
-\end{array}$ & .40 .90 & $\begin{array}{c}25 \text { emps } \\
\text { or } 3009 \\
\text { rotal wates }\end{array}$ & $\begin{array}{l}125 v a \text { pilos } \\
\text { duty ivsc } \\
\text { with d-s } \\
\text { contoctort }\end{array}$ & $\begin{array}{l}22 \text { emos } \\
\text { or } 5200 \\
\text { total wetts }\end{array}$ & $\begin{array}{l}125 v e \text { pilot } \\
\text { duty fuse } \\
\text { wöth di-f } \\
\text { contsctorl }\end{array}$ & $\begin{array}{c}18 \text { emps } \\
\text { it } \operatorname{sinho} \\
\text { total watts }\end{array}$ & $\begin{array}{l}125 v a \text { pilot } \\
\text { duty }\{\text { use } \\
\text { with ads } \\
\text { conisetor }\end{array}$ \\
\hline
\end{tabular}

40 to $90^{\circ} \mathrm{F}$.

UL Listed

GENERAL

trol service odly. Because they do not fail safe, they should ne be used for temperature limiting duty.

CAUTION: Users should install adequate back-up controls an safery devices with their electric heoring eguipment. Where the con segkences of failure may be severe, beck-up controls are essen rial. Although the safery of tite instellation is the responsibility 0 the user, Chromalox will be gled to make equipmen recommendelions.

Principle of Operation - Control action of these thermostats $j$ : provided through the prinsiple of liquid volume change. With $\mathbf{i}$ vasion in temperature, the liguid in the sensing element expand: or cortracts, causing a bellors to actuste the switchiog mechanism Housing - The control bousing and cover assembly is of hcav;: duty cast aluminum. 
Lighting Fixtures

\section{Application:}

NFW fixtures are used:

- in non-hazardous locations where protection is required from wet, dirty and corrosive atmospheres

- where cleantiness and sanitation are prime factors, such as dairies, canneries, food processing plants, bottling plants,

laboratories

- in dock areas for protection against salt spray

\section{Features:}

- One-piece high impact fiberglass housing provides durability and corrosion resistance - Energy efficient ballast is standard

- One-piece prismatic acrylic lens for resistance to accidental camage

- Plastic latches apply positive, uniform pressure on gasketing to seal against dust and moisture. Six latches per four foot unit.

- Mourting lugs for ballast and channel are molded into housing

Standard Materials:

- Reflector housing and latches - reinforced fiberglass

- Prismatic lens - acrylic plestic

- Gasket-closed cell neoprene

Standard Finishes:

- Fiberglass - pearl gray

- Acrylic plastic - clear

Size Ranges:

- 4 and 8 foot lengths

- 2 and 4 lamp

Electrical Rating Ranges:

- 120 and 277 volt

- 60 hertz

- 40 watt

\section{Certifications and}

Compliances:

- UL Standard: 1570

\section{Options:}

The following special options are available from the factory by adding suffix to Cat. No.

Suftix to be Added to

Description Fixture Cat. $\frac{n}{\pi}$

- Chain mounting assembly $\$$....... CMA

- Chain sets ......................CS

- Low temperature ballast - rated o $F$

(40 watt) ..................... BY

- Fuse and holder (one per fixture) ...... FB

- Suitable for $220 \mathrm{~V} 50 \mathrm{~Hz} . . . \ldots . .$. . Consult Crouse-Hinds

- Electronic baltast ............... S801

\footnotetext{
* Two pairs ol 4 ' lamps in tandem.

$\dagger 40$ watt ballasts ate rapid start.

$\$$ Chain sets not included. Order chain sets by adding CS 10 Cat. No.
}

CALC. W $320-31-015$

SH. 1 of 3 ATTACHMENT: $C$
Line Voltage

(60 hertz)

120

277

Lamps and Ballasts

$\begin{array}{lll}\text { Watts } & \text { Lamp } & \text { Ballast Typet } \\ 40 & \text { F } 40(112 \mathrm{Med} \text {. Bi-Pin) } & 430 \mathrm{ma}\end{array}$

Dimensions

\section{6}

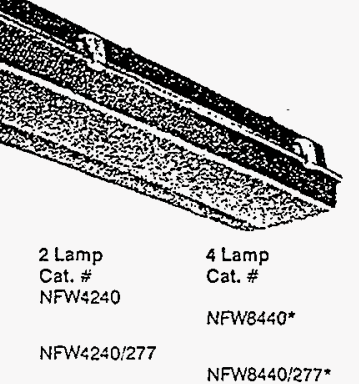

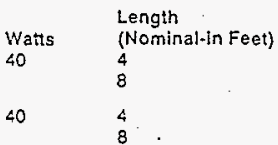

NFW4240/277

NFW8440/277
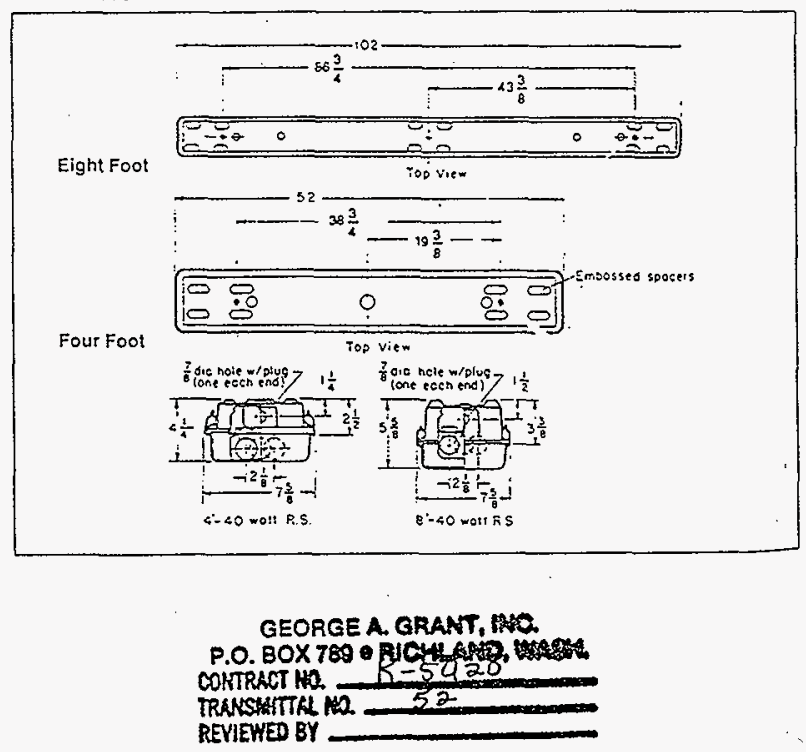

HNF-2488, Rev. 0

Page B-16

Copyrigh' 1995 Cooper Industries. Inc. 
CALC. W320-31-015

Photometric Data

Fixture: NFW4240

Lamp: 2-40/T-12

Zonal Degrees: $0.30 \quad 0.40 \quad 0-60 \quad 0.90 \quad 0.180$

Zonal Lumens: $857 \quad \begin{array}{lllll}1394 & 2478 & 3678 & 4211\end{array}$

Total Bare Lamp Lumens: $3200 \times 2=6400$

To determine number and placement of fixtures,

see Lighting Selector Guide, pages L-7 to L-12.
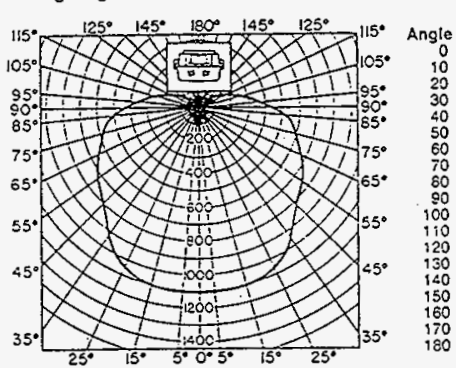

Candelas

Along Across

1166 1160

$1141 \quad 1170$

$1100 \quad 1192$

$1013 \quad 1100$

$841 \quad 1104$

631057

$2=0 \quad 610$

2.97810

18 350

14220

12 16!

530

$\begin{array}{ll}3 & 15 \\ 2 & 7\end{array}$

$\begin{array}{ll}1 & 1 \\ 0 & 0\end{array}$

Coefficient of Utilization

Efrective Floor Cavity Reflectance $20 \%$

\% Refleclance Room Cavity Ratio

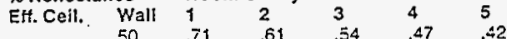

\begin{tabular}{|c|c|c|c|c|c|c|}
\hline 80 & $\begin{array}{l}50 \\
30 \\
10\end{array}$ & $\begin{array}{l}.71 \\
.68 \\
.64 \\
\end{array}$ & $\begin{array}{l}.61 \\
.56 \\
.51 \\
\end{array}$ & $\begin{array}{l}.54 \\
.47 \\
.42 \\
\end{array}$ & $\begin{array}{l}.47 \\
.40 \\
.35 \\
\end{array}$ & $\begin{array}{r}.42 \\
.35 \\
.30 \\
\end{array}$ \\
\hline 70 & $\begin{array}{l}50 \\
30 \\
10 \\
\end{array}$ & $\begin{array}{l}.69 \\
.66 \\
.63 \\
\end{array}$ & $\begin{array}{l}.60 \\
.55 \\
.50 \\
\end{array}$ & $\begin{array}{l}.52 \\
.46 \\
.41 \\
\end{array}$ & $\begin{array}{r}.46 \\
.40 \\
.35 \\
\end{array}$ & $\begin{array}{l}.41 \\
.34 \\
.30 \\
\end{array}$ \\
\hline 50 & $\begin{array}{r}50 \\
30 \\
10 \\
\end{array}$ & $\begin{array}{l}.65 \\
.62 \\
.60 \\
\end{array}$ & $\begin{array}{r}.56 \\
.52 \\
.48 \\
\end{array}$ & $\begin{array}{l}.49 \\
.44 \\
.40 \\
\end{array}$ & $\begin{array}{l}.43 \\
.38 \\
.34 \\
\end{array}$ & $\begin{array}{r}.39 \\
.33 \\
.29 \\
\end{array}$ \\
\hline 30 & $\begin{array}{l}50 \\
30 \\
10 \\
\end{array}$ & $\begin{array}{l}.61 \\
.59 \\
.57 \\
\end{array}$ & $\begin{array}{r}.53 \\
.40 \\
.48 \\
\end{array}$ & $\begin{array}{l}.46 \\
.42 \\
.38 \\
\end{array}$ & $\begin{array}{r}.41 \\
.36 \\
.33 \\
\end{array}$ & $\begin{array}{l}.37 \\
.32 \\
.28 \\
\end{array}$ \\
\hline 10 & $\begin{array}{l}50 \\
30 \\
10 \\
\end{array}$ & $\begin{array}{r}.58 \\
.56 \\
.54 \\
\end{array}$ & $\begin{array}{r}.50 \\
.47 \\
.44 \\
\end{array}$ & $\begin{array}{l}.44 \\
.40 \\
.37 \\
\end{array}$ & $\begin{array}{r}.39 \\
.35 \\
.31 \\
\end{array}$ & $\begin{array}{r}.35 \\
.30 \\
.27 \\
\end{array}$ \\
\hline 0 & 0 & .52 & .42 & .35 & .30 & .25 \\
\hline
\end{tabular}

$\%$ Reflectance Room Cavity Ratio

$\begin{array}{llllll}\text { Eft. Cell. Wall } 6 & 6 & 7 & 8 & 9 & 10\end{array}$

\begin{tabular}{cllllll} 
& & & & \\
80 & 50 & .38 & .34 & .31 & .28 & .26 \\
& 30 & .31 & .27 & .25 & .22 & .20 \\
& 10 & .26 & .23 & .20 & .18 & .16 \\
\hline \multirow{3}{*}{70} & 50 & .37 & .33 & .30 & .28 & .25 \\
& 30 & .30 & .27 & .24 & .22 & .20 \\
& 10 & .26 & .23 & .20 & .18 & .16 \\
\hline \multirow{3}{*}{50} & 50 & .35 & .31 & .29 & .26 & .24 \\
& 30 & .29 & .26 & .23 & .21 & .19 \\
& 10 & .25 & .22 & .20 & .18 & .16 \\
\hline \multirow{2}{*}{30} & 50 & .33 & .30 & .27 & .25 & .23 \\
& 30 & .28 & .25 & .23 & .21 & .19 \\
& 10 & .24 & .21 & .19 & .17 & .16 \\
\hline \multirow{2}{*}{10} & 50 & .31 & .28 & .26 & .24 & .22 \\
& 30 & .27 & .24 & .22 & .20 & .18 \\
& 10 & .24 & .21 & .19 & .17 & .15 \\
\hline 0 & 0 & .22 & .19 & .17 & .15 & .14
\end{tabular}

Fixture: FMR4240

Lamp: 2-40/T-12

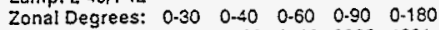

Zonal Lumens: $761 \quad 1300 \quad 2508 \quad 3826 \quad 4601$

Total Bare Lamp Lumens: $3200 \times 2=6400$

To determine number and piacement of fixtures,

see Lighting Selector Guide, pages L-7 to L-12.
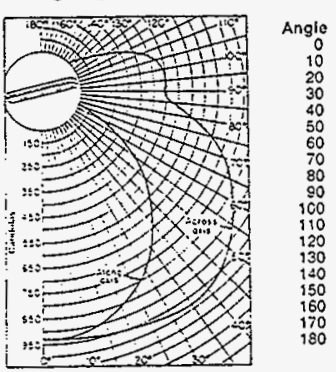

Candelas

\section{Coefficient of Utilization}

Effective Floor Cavity Reflectance 20\%

Feflectance Foom Cavity Ratio

\begin{tabular}{cllllll} 
Eff. Ceil. & Wall & 1 & 2 & 3 & 4 & 5 \\
& 50 & .69 & .59 & .51 & .45 & .40 \\
50 & 30 & .65 & .53 & .44 & .38 & .33 \\
& 10 & .62 & .48 & .39 & .33 & .28 \\
\hline \multirow{3}{*}{70} & 50 & .66 & .56 & .49 & .43 & .38 \\
& 30 & .63 & .51 & .43 & .37 & .32 \\
& 10 & .59 & .47 & .38 & .32 & .27 \\
\hline \multirow{2}{*}{50} & 50 & .61 & .52 & .45 & .39 & .35 \\
& 30 & .58 & .48 & .40 & .34 & .30 \\
& 10 & .55 & .44 & .36 & .30 & .25 \\
\hline & 50 & .56 & .48 & .41 & .36 & .32 \\
30 & 30 & .54 & .44 & .37 & .32 & .28 \\
& 10 & .51 & .41 & .34 & .28 & .24 \\
\hline \multirow{2}{*}{30} & 50 & .51 & .44 & .38 & .33 & .30 \\
& 30 & .50 & .41 & .35 & .30 & .26 \\
& 10 & .48 & .38 & .32 & .27 & .23 \\
\hline 0 & 0 & .45 & .36 & .29 & .25 & .21
\end{tabular}

$\%$ Reflectance Room Cavity Ratio

$\begin{array}{llllll} & \text { EH. Ceil. Wall } & 6 & 7 & 8 & 9\end{array}$

\begin{tabular}{|c|c|c|c|c|c|c|}
\hline $\begin{array}{c}\text { EH. Ceîl. } \\
\qquad 0\end{array}$ & $\begin{array}{l}\text { Wall } \\
50 \\
30 \\
10\end{array}$ & $\begin{array}{l}6 \\
.35 \\
.29 \\
.24 \\
\end{array}$ & $\begin{array}{l}7 \\
.32 \\
.25 \\
.21 \\
\end{array}$ & $\begin{array}{l}8 \\
.29 \\
.23 \\
.18 \\
\end{array}$ & $\begin{array}{l}9 \\
.26 \\
.20 \\
.16 \\
\end{array}$ & $\begin{array}{l}10 \\
.24 \\
.18 \\
.15 \\
\end{array}$ \\
\hline 70 & $\begin{array}{l}50 \\
30 \\
10 \\
\end{array}$ & $\begin{array}{l}.34 \\
.28 \\
.23 \\
\end{array}$ & $\begin{array}{l}.31 \\
.25 \\
.20 \\
\end{array}$ & $\begin{array}{r}.28 \\
.22 \\
.18 \\
\end{array}$ & $\begin{array}{r}.25 \\
.20 \\
.16 \\
\end{array}$ & $\begin{array}{l}.23 \\
.18 \\
.14 \\
\end{array}$ \\
\hline 50 & $\begin{array}{l}50 \\
30 \\
10 \\
\end{array}$ & $\begin{array}{l}.31 \\
.26 \\
.22 \\
\end{array}$ & $\begin{array}{l}.28 \\
.23 \\
.19 \\
\end{array}$ & $\begin{array}{l}.26 \\
.21 \\
.17 \\
\end{array}$ & $\begin{array}{l}.24 \\
.19 \\
.15 \\
\end{array}$ & $\begin{array}{r}.22 \\
.17 \\
.14 \\
\end{array}$ \\
\hline 30 & $\begin{array}{l}50 \\
30 \\
10 \\
\end{array}$ & $\begin{array}{r}.29 \\
.24 \\
.21 \\
\end{array}$ & $\begin{array}{l}.26 \\
.22 \\
.18 \\
\end{array}$ & $\begin{array}{l}.24 \\
.19 \\
.16 \\
\end{array}$ & $\begin{array}{r}.22 \\
.18 \\
.14 \\
\end{array}$ & $\begin{array}{l}.20 \\
.16 \\
.13 \\
\end{array}$ \\
\hline 10 & $\begin{array}{l}50 \\
30 \\
10 \\
\end{array}$ & $\begin{array}{l}.27 \\
.23 \\
.20 \\
\end{array}$ & $\begin{array}{l}.24 \\
.20 \\
.17 \\
\end{array}$ & $\begin{array}{l}.22 \\
.18 \\
.15 \\
\end{array}$ & $\begin{array}{r}.21 \\
.17 \\
.14 \\
\end{array}$ & $\begin{array}{r}.19 \\
.15 \\
.12 \\
\end{array}$ \\
\hline 0 & 0 & .18 & .16 & .14 & .12 & .11 \\
\hline
\end{tabular}


Straight Laings

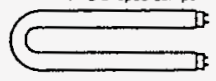

सen

start 1 lnput $3 \mathrm{~s}$, Model

SOUNO RATED A

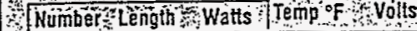

F30Ti2

\begin{tabular}{|c|c|c|c|c|c|c|c|c|c|c|c|}
\hline \multirow{4}{*}{1} & \multirow{4}{*}{$3^{\prime}$} & 25 & $60^{\circ}$ & 120 & PE1-1SAO-PH+TO & 0.24 & 27 & \multirow{4}{*}{0.85} & \multirow{4}{*}{$<0$} & \multirow{4}{*}{$>0.96$} & \multirow{4}{*}{1} \\
\hline & & 30 & 50 & 120 & 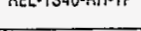 & 0.27 & 31. & & & & \\
\hline & & 25 & 60 & \multirow{2}{*}{$2 \overrightarrow{77}$} & \multirow{2}{*}{ VEL-1S40-nHH-TP } & 0.10 & 27 & & & & \\
\hline & & 30 & 50 & & & 0.12 & 31 & & & & \\
\hline \multirow{4}{*}{2} & \multirow{4}{*}{$3^{\prime}$} & 25 & 60 & \multirow{2}{*}{120} & \multirow{2}{*}{ REL-2S40-RH-TP } & 0.41 & 48 & \multirow{4}{*}{0.95} & \multirow{4}{*}{$<20$} & \multirow{4}{*}{$>0.98$} & \multirow{4}{*}{2} \\
\hline & & 30 & 50 & & & 0.51 & 60 & & & & \\
\hline & & 25 & 50 & \multirow{2}{*}{277} & \multirow{2}{*}{ VEL-2S40-RH-T? } & 0.18 & 48 & & & & \\
\hline & & 30 & 50 & & & 0.22 & 60 & & & & \\
\hline \multirow{4}{*}{3} & \multirow{4}{*}{3} & 25 & 50 & \multirow{2}{*}{120} & \multirow{2}{*}{ REL-3S+O-RH-TP } & 0.69 & 80 & \multirow{4}{*}{0.95} & \multirow{4}{*}{$<20$} & \multirow{4}{*}{$>0.97$} & \multirow{4}{*}{3} \\
\hline & & 30 & 50 & & & 0.78 & 90 & & & & \\
\hline & & 25 & 60 & \multirow{2}{*}{277} & \multirow{2}{*}{ VEL-3S40-FH.TP } & 0.30 & 80 & & & & \\
\hline & & 30 & 50 & & & 0.34 & 90 & & & & \\
\hline
\end{tabular}

F40T12 \& F40T12/U

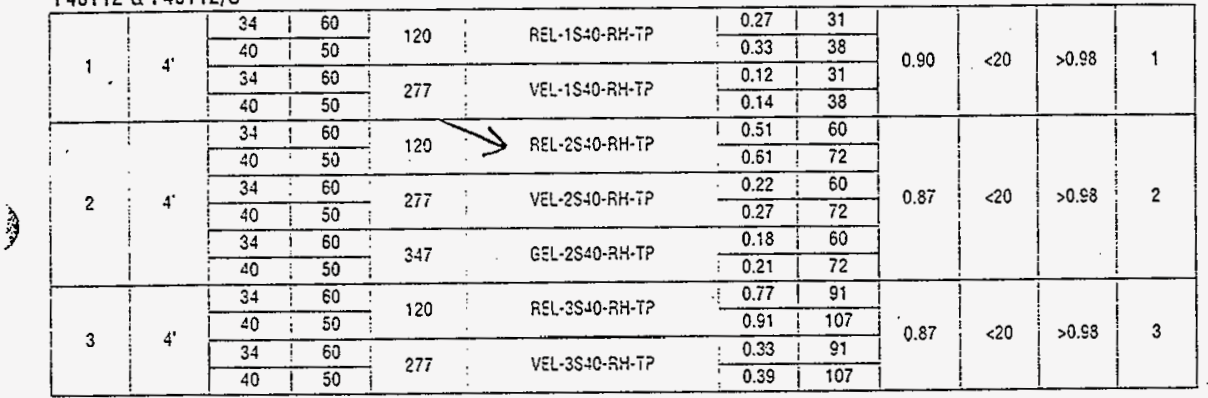

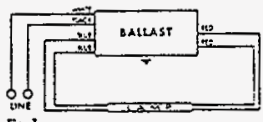

Fig. 1
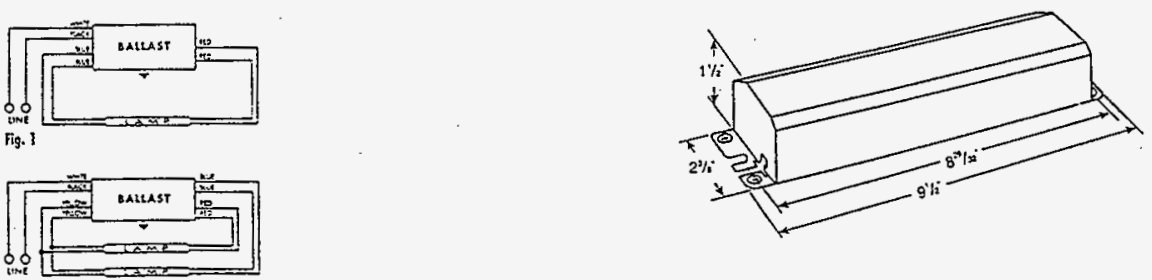

Fig. 2

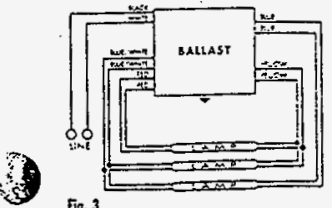

HNF-2488, Rev. 0

CALC. W320.31-015

ATTACHMENT: $C$

sht. 3 of 3

ที. 3

Page B-18

Refer to pages 144 to 145

for lead lengths and shipping data

ADYANCE, 10275 WEST HIGGINS ROAD, FOSEMONT, 16 60018. TEL: (708) 390.5000, FAX: (708) 390.5109 
Fig. 11-1. Currently Recommended Illuminance Categories and Illuminance Values for Lighting Design Targeted Maintained Levels

The following table is a consolidated listing of the IESNA's current illuminance recommendations. This listing is intendod to guide the designer in selecting an appropriate iluminance.

Guidance is provided in two forms: (i), in Parts I, II and III as 1 an Illuminanco Category, reprosenting a rango of illuminances; - and (2), in Parts IV, $V$ and $V I$ as an IIIuminanco Value. "Illuminance cetegories are representod by letter designations $A$ through I. flluminance Values are given in lux with oquivalents in footcandles and as such are intended as targot values with deviations expocted. Theso target values also represent maintained values.
This table has boen drvided into six parts for ease of use. Part I lists both Illuminance Categories and liluminarice Values for generic types of interior activites and nomally is to be used when Illuminance Categories for a spesific Area/Activity cannot bo lound in Parts II and III. Parts IV, V and VI provido target maintained lliuminance Values for ouldoor facilities, sports and recreational areas, and transpontation vehicles where special considerations apply as discussed.

In all cases the recommondations in this table are based on the assumption that the lighting will bo property designed to take into account the visual characteristics of the tesk.

1. Iltuminance Categortes and Illuminance Values for Generic Types of Activities in Interiors

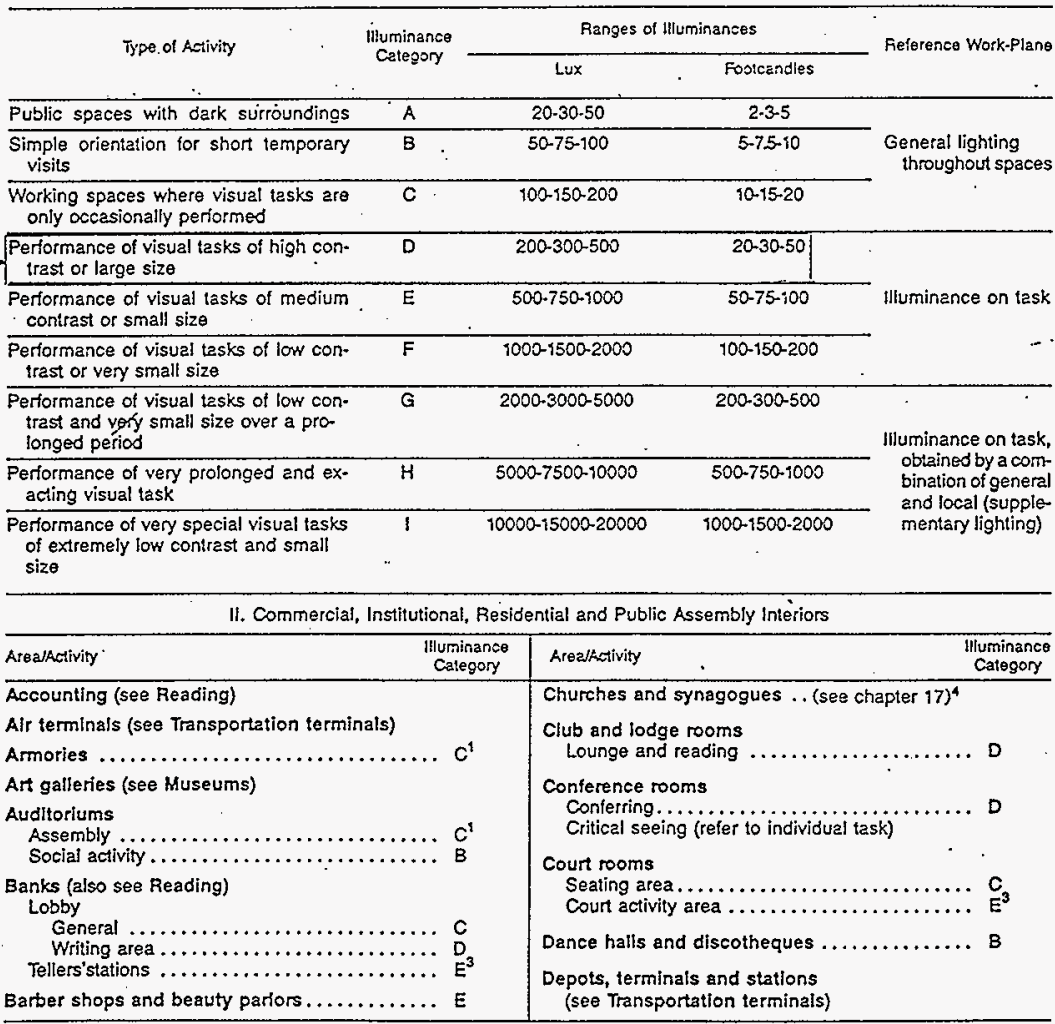

For tootnoles, see end of tabie.

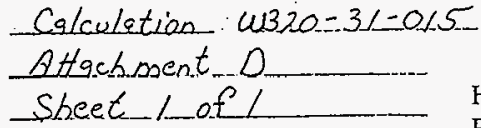

HNF-2488, Rev. 0

Page B-19 
Table 9.2-204 Procedure for Calculating Footcandles and Watts Per Square Foot

1. Initial footcandles $=$ No. of fixtures $\times$ lamps per fixture $\times$ lumens per lamp $\times$ coefficient of utilization $\div$ square feet

2. Maintaine do fotcandles $=$ initial footcandles $x$ maintenance factor

3. Watts per square foot $=$ No. of fixtures $\mathrm{x}$ lamps $\times$ (lamp watts + ballast watts) $\div$ square feet.

Example - To find footcandles and watts per S.F. for an office $20^{\prime} \times 20^{\prime}$ with 11 fluorescent fixtures each having $4-40$ watt C.W. lamps.

Based on good reflectance and clean conditions:

Lumens per: Jamp $=40$ watt cool white at 3150 lumens per lamp (Table C9.2-251)

Coefficient of utilization $=.42$ (varies from .62 for light colored areas to .27 for dark)

Mainteńance factor $=.75$ (varies from .80 for clean areas with good maintenance to .50 for poor)

Ballast loss $=8$ watts per lamp. (Varies with manufacturer. See manufacturers' catalog.)

17

1. Initial footcandies:

$\frac{11 \times 4 \times 3150 \times .42}{400}=\frac{58212}{400}=145$ footcendles

2. Maintained footcandies:

$145 \times .75 \square 109$ footcandles

3. Watts per S.F.

$\frac{11 \times 4 \times(40+8)}{400}=\frac{2112}{400}=5.3$ watts per S.F.

Table 9.2-205 Approximate Watts Per Square Foot for Popular Fixture Types.

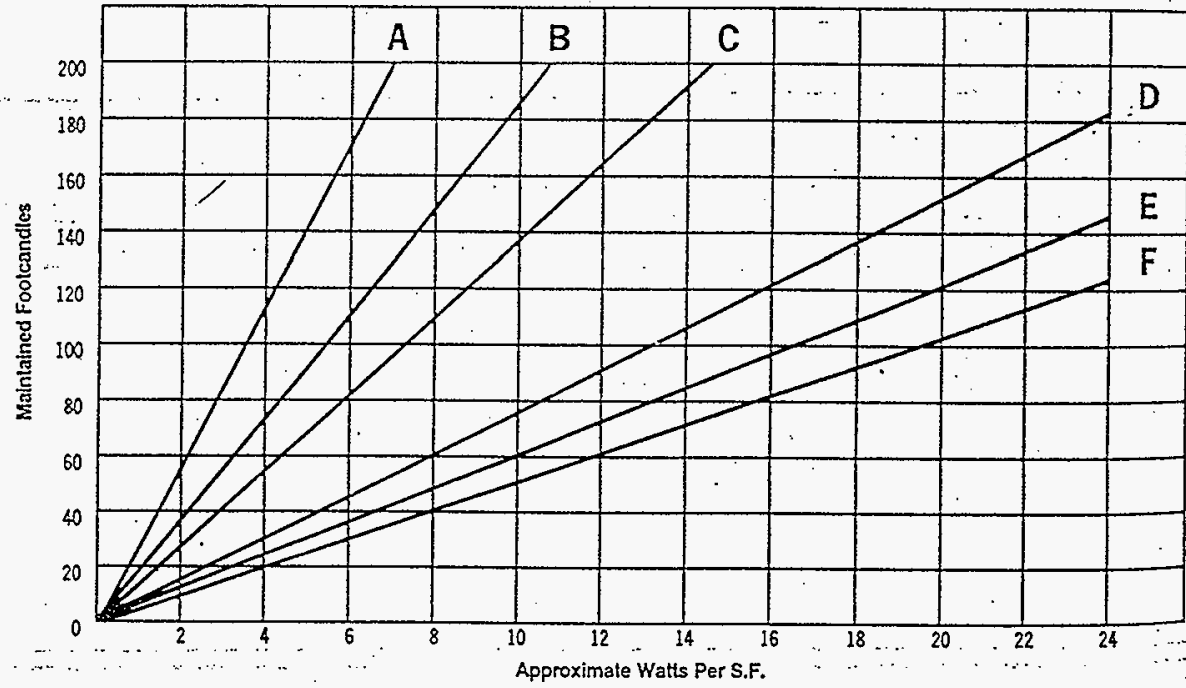

Due to the many variables involved, use for preliminary estimating only:

A. Fluorescent - industrial System B9.2-212

B. Fluorescent - lens unit System B9.2-212 Fixture types B \& C

C. Fluorescent - louvered unit

D. Incandescent - open reflector System B9.2-222, Type D

E Incandescent - lens unit System B9.2-222, Type A

F. Incandescent - down light System B9.2-222, Type B

From: Megns Electrical Cost Data 1991

HNF-2488, Rev. 0

Calculation : W3zo-31-015 AHachment $E$

Page B-20 


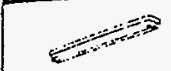

A. Strip Fixture

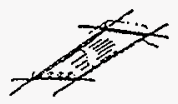

c. Recessed

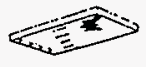

B. Surface Mounted

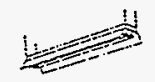

D. Pendent Mounted
Design Assumptions:

1. A 100 tootcandle average maintained level of illumination.

2. Ceiling heights range from $g^{\prime}$ to 11 '.

3. Average reflectance values are assumed for ceilings, walls and floors.

4. Cool white (CW) fluorescent lamps with 3150 lumens for 40 watt lamps and 6300 lumens for 8 ' slimline lamps.

5. Four 40 watt lamps per $44^{\prime}$ fixture and two $8^{\prime}$ lamps per $8^{\prime}$ fixture.

6. Average fixture efficiency values and spacing to mounting height ratios.

7. Installation labor is average U.S. rate as of January 1.

\section{System Components}

\section{SYSTEM 09.2.212.0520}

FUORESCENT FLXTURES MOUNTED 9'.11' RBOVE FLOOR, 100 FC

TYPE R, 8 FUXNURES PER 400 S.F.

Sieel intermediate condut, (IMC) $h^{\prime \prime}$ diam

Wire, 600 , type THWN-THhN, copper, solid, E12

Fluotescent strip fixture $8^{\prime}$ long, suface mounted, two $75 \mathrm{~W}$ SL.

Steel ouritet box $4^{\circ}$ concrete.

Steel oudet box plate with sud, $4^{\prime \prime}$ concrete

\begin{tabular}{|c|c|c|c|c|c|}
\hline & \multirow{2}{*}{ OUANTITY } & \multirow[b]{2}{*}{ UNIT } & \multicolumn{3}{|c|}{ COST PER S.F. } \\
\hline & & & MRT. & INST. & TOTAL \\
\hline & .404 & L.F. & .29 & 1.20 & 1.59 \\
\hline & .008 & C.L.F. & .05 & .21 & .26 \\
\hline & .020 & Es. & 1.00 & .97 & 2 \\
\hline & .020 & Ea. & .10 & .30 & .40 \\
\hline & .020 & Ea. & .04 &.$\Phi$ & .11 \\
\hline TOTRL & & & 1.61 & 2.75 & 4.35 \\
\hline
\end{tabular}

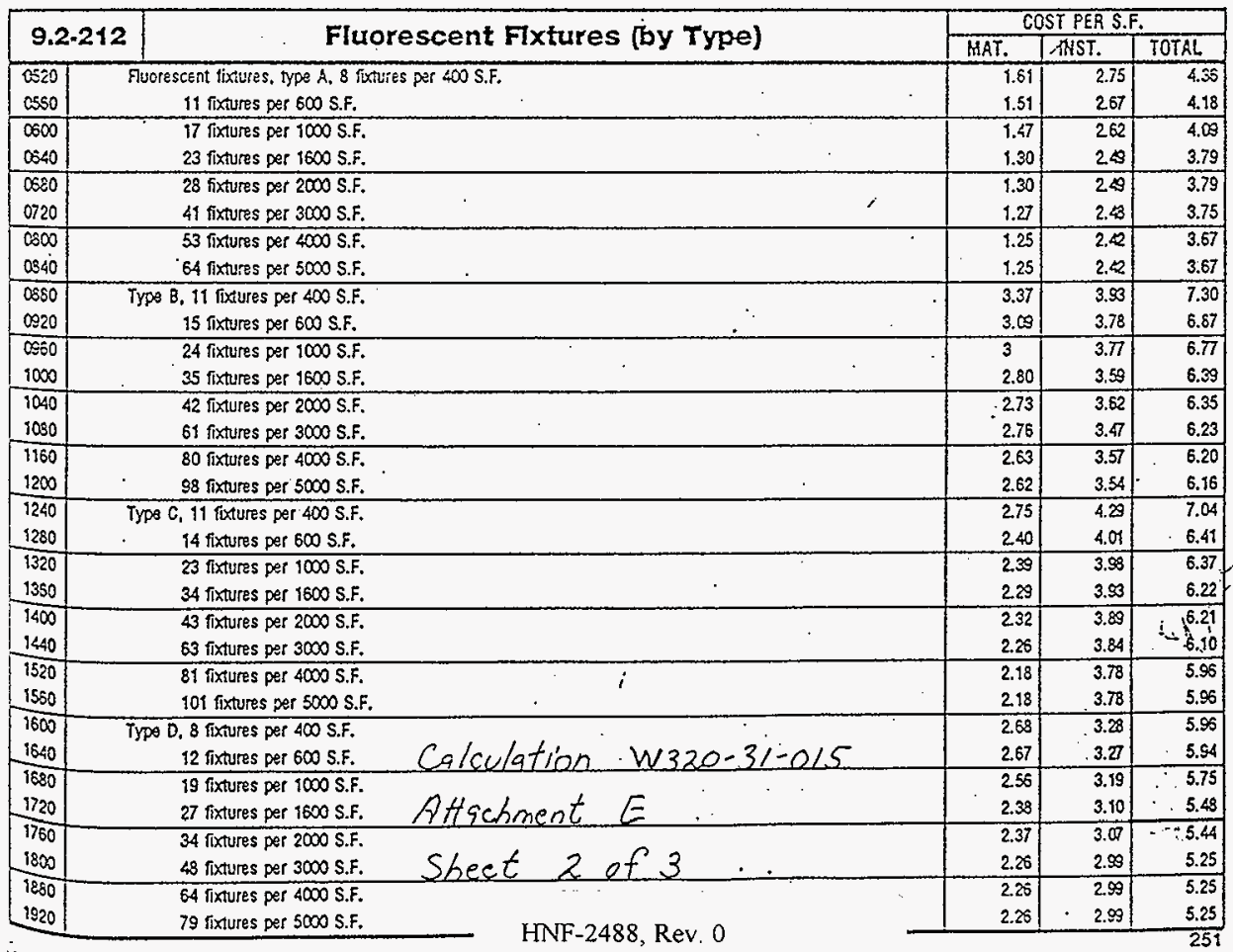




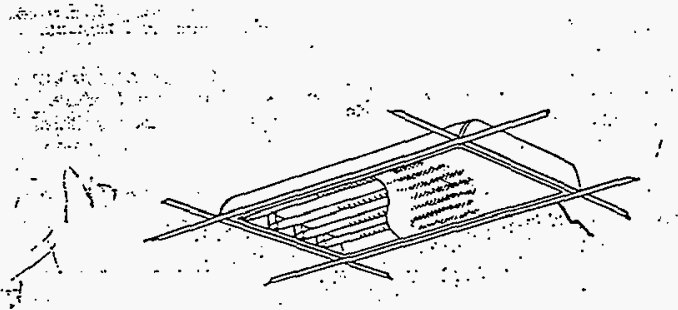

Type C. Recessed, mounted on grid ceiling supsension system, 2' $\times$ 4', four $^{\prime}$ 40 watt lamps, acrylic prismatic diffusers.

5.3 watts per S.F. in 100 footcandles. 3 watls per S.F. for 57 footcandles.

\section{System Components}

\section{SYSTEM 09.2-213.0200}

FLUORESCENT FIXTURES RECESS MOUNTED IN CEILNQ

I WATT PER S.F., 20 FC, 5 FIXTURES PER 1000 S.F.

Steel intermediate conduit, (IIMC) $\%{ }^{*}$ diam

Wire, 600 volt, type THW, Copper, solid, E12

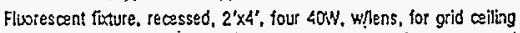
Steel oythet box $4^{\prime \prime}$ sp̧uers

Fixture whip, Greenfild W/IT2 ThHN wire

\begin{tabular}{|c|c|c|c|c|c|}
\hline & \multirow[b]{2}{*}{ OUANTITY } & \multirow[b]{2}{*}{ UNIT } & \multicolumn{3}{|c|}{ COST PER S.F. } \\
\hline & & & IMAT. & INST. & TOTAL \\
\hline & .128 & L.F. & .12 & .33 & $.5 \%$ \\
\hline & .023 & C.L.F. & .02 & .08 & .30 \\
\hline ceiling & .035 & E. & .35 & .33 & .68 \\
\hline . & $\cdots .005$ & Er. & .03 & .07 & .10 \\
\hline & -.005 & E2. & $.0 i$ & $\mathscr{Q}$ & .03 \\
\hline TOTAL & & & .53 & .88 & 1.41 \\
\hline
\end{tabular}

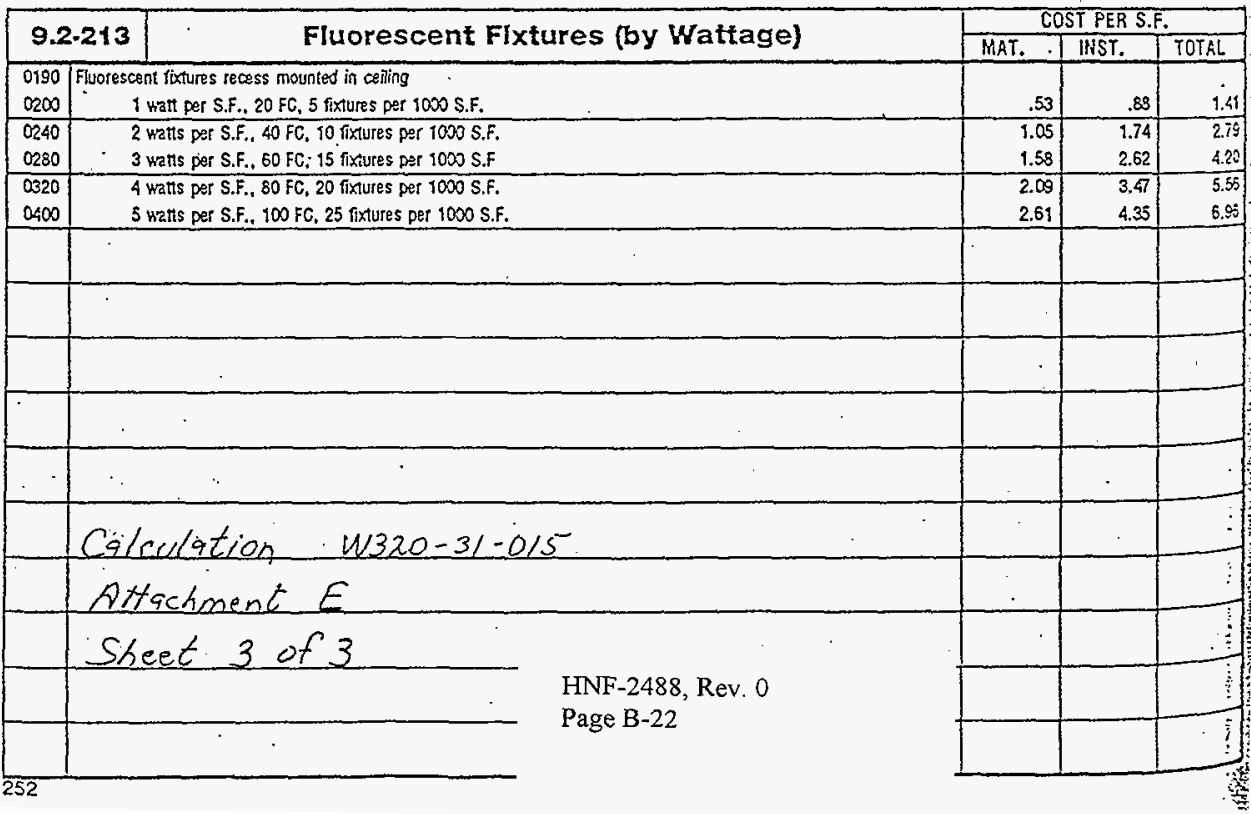




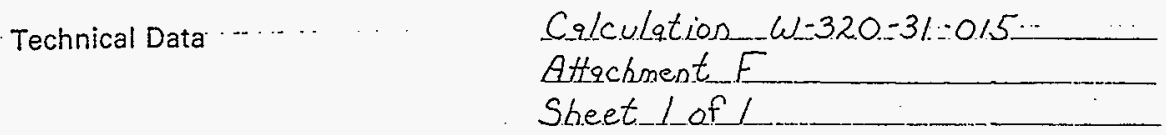

Calculation $\omega-320-3 /=015 \ldots$

Sheet_l_of/

Typical Data for 600 Volt Class Dry-Type Transformer

\begin{tabular}{|c|c|c|c|c|c|c|c|c|c|c|c|c|c|c|c|c|}
\hline \multirow[t]{2}{*}{ KVA } & \multirow[t]{2}{*}{ Type } & \multirow{2}{*}{$\begin{array}{l}\text { Deg. C } \\
\text { Rise }\end{array}$} & \multicolumn{5}{|c|}{ Dimensions. (In.) } & \multicolumn{2}{|c|}{$\begin{array}{l}\text { Losses in } \\
\text { Watts }\end{array}$} & \multicolumn{4}{|c|}{ Efficiency } & \multicolumn{3}{|c|}{$\%$ Regulation } \\
\hline & & & Height & Width & Depth & $\begin{array}{l}\text { Weight } \\
\text { (Alum) } \\
\text { Lbs. }\end{array}$ & $\begin{array}{l}\text { Weight } \\
\text { (Cu.) } \\
\text { Los. }\end{array}$ & N.L. & Total & $\begin{array}{l}1 / 4 \\
\text { Load }\end{array}$ & $\begin{array}{l}1 / 2 \\
\text { Load }\end{array}$ & $\begin{array}{l}3 / 4 \\
\text { Load }\end{array}$ & $\begin{array}{l}\text { Full } \\
\text { Load }\end{array}$ & $\begin{array}{l}100 \% \\
\text { P.F. }\end{array}$ & $\begin{array}{l}80 \% \\
\text { P.F. }\end{array}$ & $\%$ imp. \\
\hline 0.25 & $E P$ & 80 & $71 / 16$ & $4 \%$ & $4 \%$ & & 12 & 13 & 36 & 80.0 & 82.0 & 85.0 & 87.5 & 9.2 & 8.0 & 9.24 \\
\hline 0.5 & & 80 & $71 / 16$ & $42 / s$ & $45 \%$ & & 13 & 20 & 45 & 85.2 & 90.5 & 91.6 & 91.8 & 5.07 & 4.54 & 5.12 \\
\hline 0.75 & & 80 & 836 & 6 & $5 / 2$ & & 20 & 21 & 54 & 89.1 & 92.8 & 93.5 & 93.3 & 4.14 & 3.33 & 4.44 \\
\hline 1 & & 80 & $83: 8$ & 6 & $51 / 2$ & & 30 & 29 & 71 & 95.2 & 96.0 & 96.0 & 85.1 & 4.09 & 3.62 & 4.18 \\
\hline 1.5 & & 80 & $10 \%$ & $63 / 6$ & $6 \%$ & & 40 & 37 & 92 & 94.5 & 95.5 & 95.1 & 94.3 & 3.83 & 3.60 & 3.70 \\
\hline 2 & & 80 & $101 / 2$ & $63 / 4$ & $61 \%$ & & 40 & 37 & 97 & 95.4 & 96.5 & 96.4 & 96.0 & 3.18 & 3.30 & 3.42 \\
\hline 3 & & 115 & $14 \%$ & $751 / 16$ & 8 & 65 & 69 & 74 & 144 & 95.0 & 96.3 & 96.3 & 95.9 & 3.25 & 3.50 & 3.53 \\
\hline 5 & & 115 & 16 & $103 / 8$ & $9 \%$ & 113 & 120 & 104 & 201 & 96.6 & 97.35 & 97.2 & 96.85 & 2.58 & 2.50 & 2.64 \\
\hline 7.5 & & 115 & 16 & $10 \frac{1 / 8}{8}$ & $9 \%$ & 123.- & 133 & 149 & 271 & 97.0 & 97.65 & 97.5 & 97.15 & 2.31 & 2.50 & 2.54 \\
\hline - 10 & & 115 & 19 & $13 \%$ & $101 / 2$ & 193 & 208 & 160 & 317 & 96.1 & 97.3 & 97.4 & 97.25 & 1.95 & 2.10 & 2.18 \\
\hline 15 & & 115 & 19 & $13^{3 / 2}$ & $101 / 2$ & 216 & 235 & 230 & 454 & 97.6 & 98.15 & 98.1 & 97.8 & 1.71 & 1.80 & 1.85 \\
\hline 25 & & 115 & $22 / 16$ & $16^{3 / 4}$ & $14 \%$ & 385 & 494 & 284 & 550 & 97.3 & 98.0 & 98.0 & 97.8 & 1.18 & 1.63 & 1.65 \\
\hline 3 & EPT & 115 & $13 \%$ & $1515 / 15$ & $85 / 18$ & 116 & 123 & 121 & 189 & 34.2 & 94.75 & 94.0 & 92.9 & 6.73 & 7.9 & 7.93 \\
\hline 6 & & 115 & $15 \%$ & $161 / 2$ & $9 \%$ & 143 & 153 & 140 & 288 & 93.6 & 95.3 & 95.2 & 94.8 & 3.35 & 3.6 & 3.7 \\
\hline 9 & & 115 & $15 \%$ & $161 / 2$ & $9 \%$ & 166 & 178 & 199 & 412 & 96.0 & 96.8 & 96.7 & 96.2 & 3.07 & 3.4 & 2.96 \\
\hline 15 & & 115 & 1736 & $191 / 18$ & $10 \% / 6$ & 275 & 300 & 216 & 534 & 96.9 & 97.5 & 97.4 & 97.0 & 2.38 & 2.91 & 2.8 \\
\hline 30 & & 115 & $26 \%$ & $251 / 8$ & $12 \%$ & 422 & 504 & 229 & 681 & 96.7 & 97.8 & 97.9 & 97.8 & 1.51 & 2.12 & 2.14 \\
\hline 25 & DS-3. & 150 & $37 \%$ & $221 / 2$ & 20 & 310 & 360 & 200 & 1050 & 96.1 & 96.8 & 96.6 & 96.0 & 3.5 & 4.0 & 4.0 \\
\hline 37.5 & & 150 & $43 y_{4}$ & $22^{1} / 2$ & 20 & 375 & 450 & 250 & 1550 & 96.1 & 96.8 & 96.5 & 96.0 & 3.5 & 5.1 & 5.2 \\
\hline 50 & & 150 & $433 / 4$ & $221 / 2$ & 20 & 425 & 500 & 300 & 1950 & 95.8 & 97.2 & 96.8 & 96.2 & 3.5 & 5.9 & 6.6 \\
\hline 75 & & 150 & $52 \%$ & 26 & $24 \%$ & 635 & 725 & 350 & 2750 & 97.7 & 98.2 & 98.1 & 97.8 & 2.1 & 5.5 & 7.6 \\
\hline 100 & & 150 & $52 h$ & 26 & $24^{2 / 2}$ & 725 & 825 & 450 & 2850 & $\$ 7.7$ & 97.9 & 97.6 & 97.5 & 2.7 & 5.7 & 7.3 \\
\hline 167 & & 150 & $62 \%$ & 30 & 34 & 1200 & 1350 & 750 & 3250 & 97.8 & $\$ 8.3$ & 98.3 & 98.0 & 1.7 & 5.1 & 6.8 \\
\hline 15 & DT.3 & 150 & 25 & $20 \%$ & $14 \%$ & 152 & 172 & 150 & 875 & 95.0 & 95.5 & 95.3 & 94.5 & 4.8 & 5.0 & 5.2 \\
\hline 30 & & 150 & $30 \%$ & $20 \%$ & $14 \%$ & 230 & 300 & 200 & 1600 & 96.3 & 96.5 & 95.9 & 95.0 & 4.7 & 5.6 & 5.6 \\
\hline 45 & & 150 & $30 \%$ & $201 / 8$ & $141 / 8$ & 310 & 370 & 300 & 1900 & 98.5 & 96.9 & 96.5 & 96.1 & 3.7 & 4.5 & 4.5 \\
\hline 75 & & 150 & $37 \%$ & $261 / 8$ & $191 / 3$ & 480 & 550 & 400 & 3000 & 97.0 & 97.2 & 96.8 & 96.1 & 3.6 & 4.9 & 4.9 \\
\hline 112.5 & & 150 & $37 \%$ & $261 / 8$ & $191 / 8$ & 600 & 675 & 500 & 4900 & 97.3 & 97.2 & 96.6 & 95.8 & 3.9 & 5.8 & 5.9 \\
\hline 150 & & 150 & $46 \%$ & 26 & $20 \% / 15$ & 760 & 850 & 600 & 6700 & 97.4 & 97.2 & 96.5 & 95.7 & 3.8 & 5.7 & 6.2 \\
\hline 225 & & 150 & 56 & $311 / 4$ & $243 / 4$ & 1100 & 1200 & 700 & 8600 & 97.9 & 97.7 & 97.0 & 96.3 & 3.7 & 6.0 & 6.4 \\
\hline 300 & & 150 & 56 & $31 \%$ & $24 \%$ & 1300 & 1750 & 800 & 10200 & 98.2 & 97.9 & 97.4 & 97.6 & 3.4 & 6.3 & 7.1 \\
\hline 500 & & 150 & 75 & $441 / 2$ & 36 & 2400 & 3100 & 1700 & 9000 & 98.4 & 98.7 & 98.6 & 98.4 & 1.5 & 4.2 & 5.5 \\
\hline 750 & & 150 & 75 & $44 \%$ & 36 & 2900 & 3600 & 2200 & 11700 & 98.4 & 98.7 & 98.7 & 98.5 & 1.5 & 4.7 & 6.3 \\
\hline 1000 & & 150 & 75 & 47 & 41 & 4000 & $\rightarrow$ & 2800 & 13600 & 98.6 & 98.9 & 98.8 & 98.6 & 1.2 & 4.7 & 6.5 \\
\hline 15 & & .115 & 25 & $20 \%$ & $141 / 1$ & 152 & 172 & 150 & 700 & 95.3 & 96.3 & 96.1 & 95.6 & 3.8 & 5.1 & 5.2 \\
\hline 30 & & 115 & $30 \%$ & $20 \%$ & $14 \%$ & 230 & 300 & 200 & 1500 & 96.4 & 96.6 & 96.1 & 95.3 & 4.3 & 4.5 & 5.3 \\
\hline 45 & & 115 & $30 \%$ & $20 \%$ & $14 \%$ & 310 & 370 & 300 & 1700 & 96.7 & 97.2 & 96.9 & 96.4 & 3.1 & 3.7 & 3.7 \\
\hline 75 & & 115 & $37 \%$ & $26 \%$ & $19 \%$ & 480 & 550 & 400 & 2300 & 97.3 & 87.7 & 97.5 & 97.0 & 2.6 & 4.0 & 4.6 \\
\hline 112.5 & & 115 & $37 \%$ & $26 \%$ & $19 \%$ & 600 & 675 & 500 & 3100 & 97.7 & 98.0 & 97.7 & 97.3 & 2.5 & 5.5 & 6.5 \\
\hline 150 & & 115 & $461 / 2$ & 26 & $203 / 16$ & 760 & 850 & 600 & 5900 & 97.8 & 97.9 & 97.5 & 97.1 & 3.8 & 5.9 & 6.2 \\
\hline 225 & & 115 & 56 & $31 \%$ & $24 \%$ & 1100 & 1200 & 700 & 6000 & 98.2 & 98.2 & 97.9 & 97.4 & 2.5 & 5.7 & 7.2 \\
\hline 300 & & 115 & 56 & $311 / 4$ & $241 / 4$ & 1300 & 1750 & 800 & 6600 & 98.4 & 98.5 & 98.2 & 87.9 & 2.1 & 5.0 & 6.3 \\
\hline 500. & & 115 & 75 & $441 / 2$ & 36 & 2400 & 3100 & 1700 & 6800 & 98.4 & 98.8 & 98.8 & 98.7 & 1.2 & 4.1 & 5.5 \\
\hline 15 & & 80 & $30 \%$ & $20 \%$ & $141 / 2$ & 230 & 300 & 200 & 500 & 94.5 & 96.4 & 96.8 & 96.8 & 2.0 & 2.2 & 2.3 \\
\hline 30 & & 80 & $30 \%$ & $20 \%$ & $14: /$ & 370 & 370 & 300 & 975 & 95.5 & 96.8 & 97.0 & 96.8 & 2.3 & 2.9 & 2.9 \\
\hline 45 & & 80 & $37 \%$ & $26 \%$ & $191 / 2$ & 480 & 550 & 300 & 9100 & 97.0 & 97.8 & 97.8 & 87.6 & 1.8 & 2.8 & 2.8 \\
\hline 75 & & 80 & $37 \%$ & $26 \%$ & $13^{1 / 2}$ & 600 & 675 & 400 & 1950 & 97.5 & 97.9 & 97.8 & 97.4 & 2.2 & 3.5 & 3.7 \\
\hline 112.5 & & 80 & $461 / 2$ & .26 & $203 / 16$ & 750 & 850 & 600 & 3400 & 97.3 & 97.7 & 97.4 & 97.0 & 2.6 & 4.1 & 4.3 \\
\hline 150 & & 80 & 56 & $31 \%$ & $241 / 4$ & 1100 & 1200 & 700 & 3250 & 97.8 & 98.2 & 98.1 & 97.9 & 1.8 & 3.6 & 4.1 \\
\hline 225 & & 80 & 56 & $31 \%$ & $241 / 4$ & 1300 & $1750^{\circ}$ & 800 & 4000 & 98.2 & 98.6 & 98.5 & 98.2 & 1.6 & 4.2 & 5.3 \\
\hline 300 & & 80 & 75 & $441 / 2$ & 36 & 2400 & 3100 & 1700 & 4300 & 87.6 & 98.4 & 98.6 & 98.6 & 1.9 & 2.7 & 4.1 \\
\hline 500 & & 80 & 75 & $441 / 2$ & 36 & 2900 & 3600 & 2000 & 5500 & 98.9 & 98.9 & 98.8 & 98.2 & 1.2 & 4.0 & 4.5 \\
\hline
\end{tabular}


800 Volt. Oopper Conductor, Themoplastlo Insulatlonatyon Shoath. Heat, Molature, Oll \& Quollne Reslstant', Alt atsos Rated THWH.2. All stranded slzon Rated MTW. AWa stses 4.4 Through 8 AWG Rated AWH $\left(105^{\circ} \mathrm{C}\right)$. AWQ Slzes 14 Throigh V. $\frac{22668 \text { SUP029 }}{250-251}$
SHT. $\frac{251}{\text { Mo24l }}$

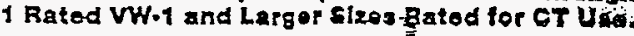

\section{APPLICATIONS}

Southwlre Type THKN or THWN-2 conductors are orimarlly Usad in condult and cable trays for services, feeders, and branch clicults in commerelaj or industrial epplications as specilted in the Natlonal Electrical Coder. When used as Type THHN, conductor is suitabio for use in dry locations at temperatures not to exceed $90^{\circ} \mathrm{C}$. When used as Type THWN-2, conductor is sultable for use in wet or dy locations at temperatures not to exceed $90^{\circ} \mathrm{C}$ or not 10 exceed $75^{\circ} \mathrm{C}$ when exposed to oll or coolant. When used as Type MTW, conductor ls sultable for use in wet locations or when exposed to oll or coolant at temperatures not to excesd $60^{\circ} \mathrm{C}$ or dry locations at temperatures not to excesd $90^{\circ} \mathrm{C}$ (with ampecthy limited to that for $75^{\circ} \mathrm{C}$ conductor temperature per NFPA 79). Conductor temperatures not to exceed $103^{\circ} \mathrm{C}$ in ory locations when rated AWM and used as appliance wiring materlal. Voltzge for all applicattone is 600 volts.

\section{BPECIFIOATIONS}

Southwirs Type THHN or THWN-2 or MTW (also AWM) meets or excesds all applicable ASTM speclflcatlons, UL standard 83, UL standard 1083 (MTW). Federal Specinication J-C-308, and requirements of the Natlonel Electrical Code.

\section{CONSTRUCTION}

Southwlre Type THHN or THWN-2 or MTW copper conductors are annealed (sot) copper, insulated with a tough, heat and molsture resistant polyvinyl chlorlde (PVC), over which a nylon (polyamlde) or UL-ilsted equal jackat is appiled. Avallable in black, white, red, blue, green, yellow, brown, orange, or grey. Some colors standard, some subject to aconomle order quantty. Sizes $1-19$ through $1,000 \mathrm{kcmill}$ avallable in black only.

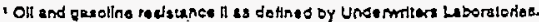

1898 Edition.

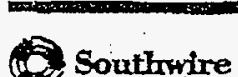

HNF-2488, Rev. 0

Page B-24 
2.501 p.ooxe 01104

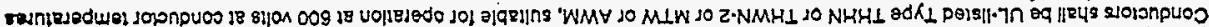

(IMY)

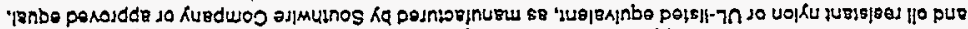

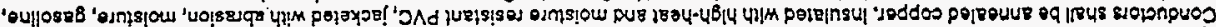

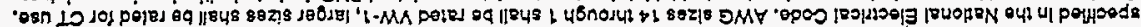

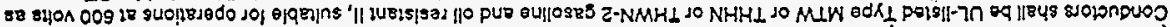

(Z-NMHL \&O NHHL YO MLI)

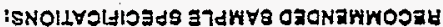

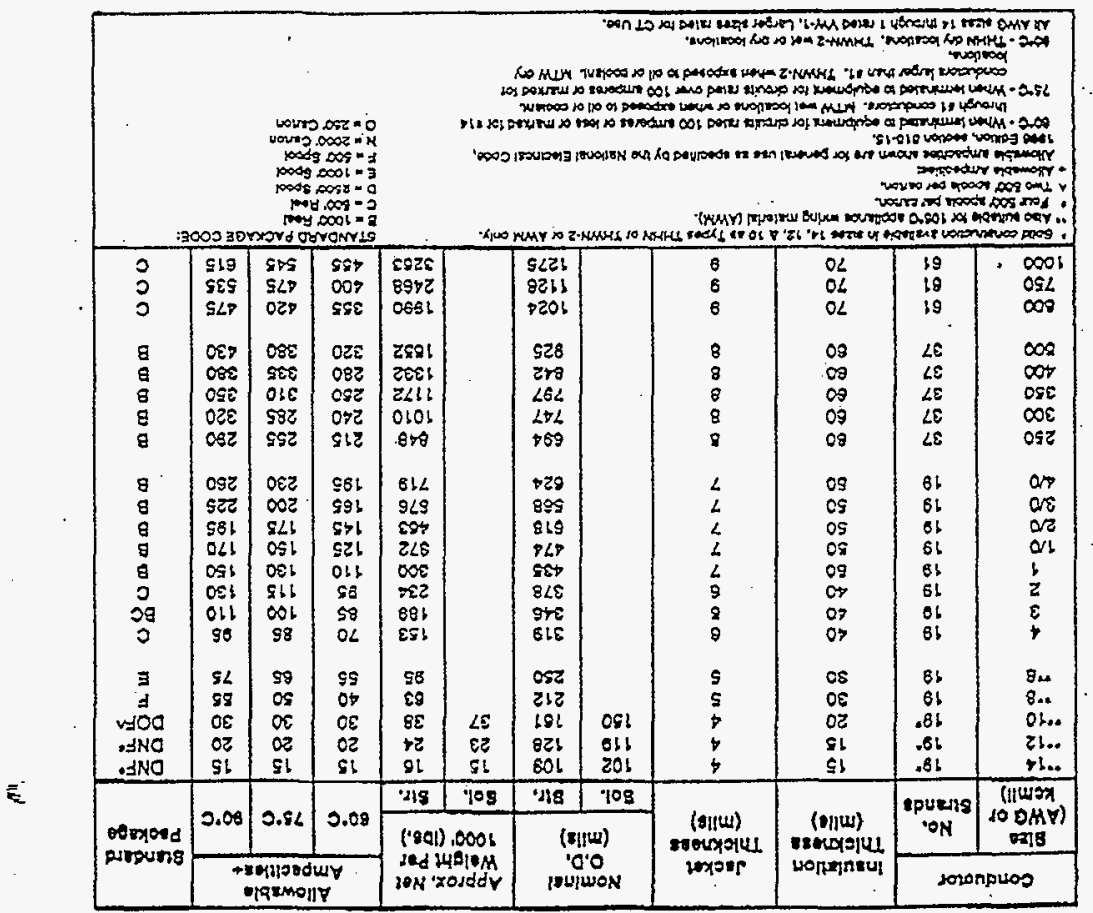


42] From: Shana L Sovern at $\sim \mathrm{HHCl} 160$ 5/17/94 2:55PM (1774 bytes: 33 In) o: Daniel E Larson at -KEH13, Timothy J Kasnick at kHC61 ubject: CODE QUESTION

Message Contents

Dan,

NEC Art. 310, table 310-16, the heading for the ampacity of conductors is for not more than three conductors in a raceway and is based on 86 degrees $F$. If the ambient temperature is subject to vary appropriate multipljers are given on the correction factor table below table 310-16.

This applies oniy to the ampacity of that conductor in that wireway.

NEC Art.110-14(c) applies to where the termination of the conductor is made. If the circuit breaker is rated for 60 degree at the termination, the allowable ampacity of that wire is then taken from the 60 degree column of table 310-16.

Hope this answers your question.

Thanks, Shana Sovern

Several weeks ago I asked you a question having to do with the connection between two sections of the code; NEC 110-14 (c) Temperature Limitations and ampacity Table 310-16.

You did a good job of explaining that the two areas are like "apples and oranges." The table is meant for cables in raceway or earth and is not meant for the temperature imitation criteria of 110-14 (c). They are to be looked at separately.

I was hoping to have a CC:mail verifying what we discussed. Hould you please send me one? I've had this discussion with several people and a cc:mail would put it to rest.

Thanks; Dan Larson

Calculation ‥W320-31-015.

AHachment $H$

sheet 1 of 1

HNF-2488, Rev. 0

Page B-26 


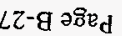

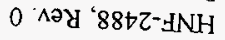

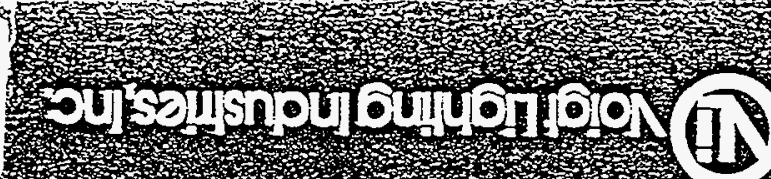

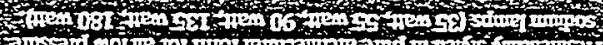

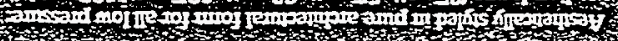
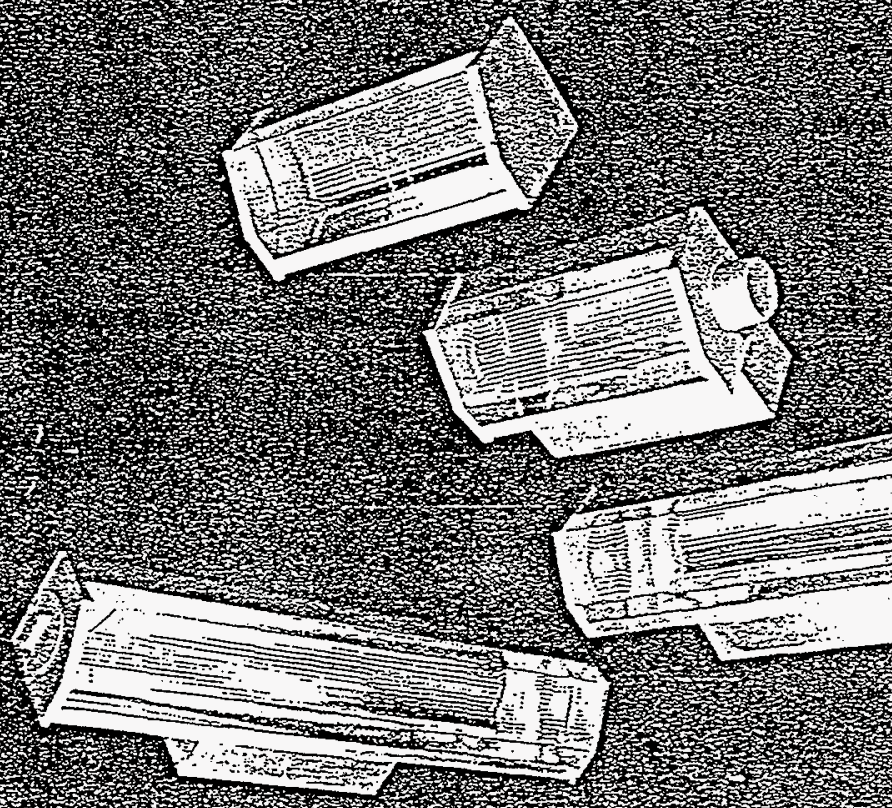

7.

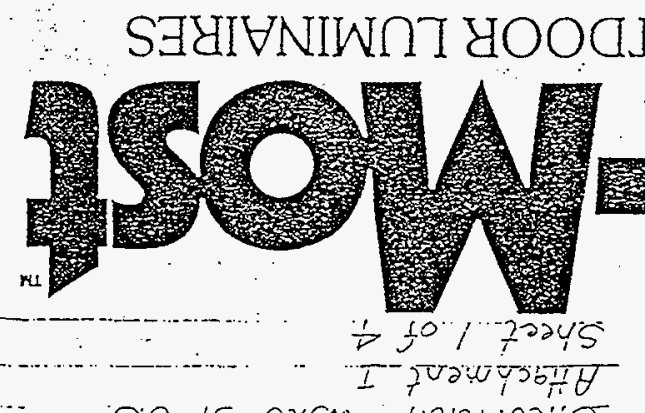

LOO JO XIIWHA 
Outdoor Energy-Dollar Saver Check-Chart

\begin{tabular}{|c|c|c|}
\hline & & $\begin{array}{c}\text { Aanual } \\
\text { Dollar } \\
\text { Soving } \\
\text { for } \\
\text { Nightly } \\
\text { Uste } \\
\text { (6c/Kwhr }\end{array}$ \\
\hline & & 58 \\
\hline & & 89 \\
\hline & & 101 \\
\hline & & 187 \\
\hline & & $\begin{array}{r}30 \\
-\quad \\
\end{array}$ \\
\hline & & 66 \\
\hline & & 59 \\
\hline & & 32 \\
\hline
\end{tabular}

Whether you seek to.

Protect visitors in a parking lot

Secure a ience against intruders

Highlight a building entrance

- Provide visibility for your watchman

Pour light into a loading 18-wheeler

Or

Assure proper T.V. survelilance lighting

The Wall-Most family does it exceptionally well and aftractively using fewer watts and often for a much smaller dollar outlay.

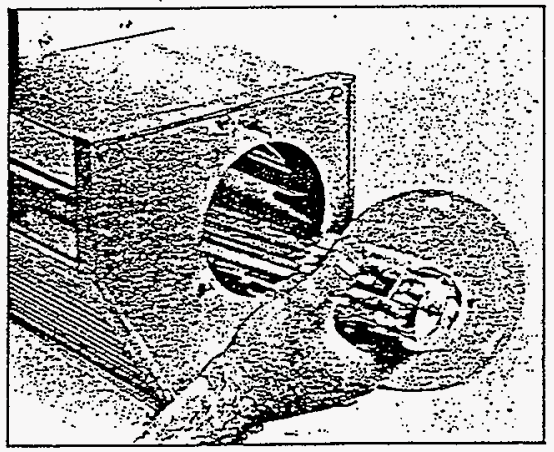

Relamping is accomplished through fully-gasketed door in end-keeping optical chamber sealed against bug and dirt entry.
Shect 2 of 4

HNF-2488, Rev. 0 Page B-28

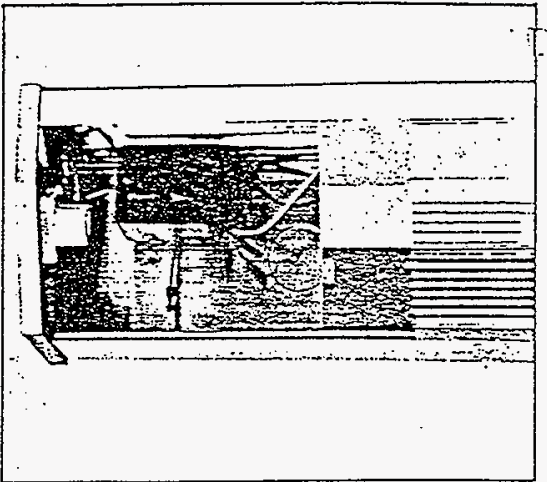

Installation, even under adverse outdoor conditions, is remarkably easy; with all mounting bolts and wire splices fully accessible as lens \& reflector slide out of the way.

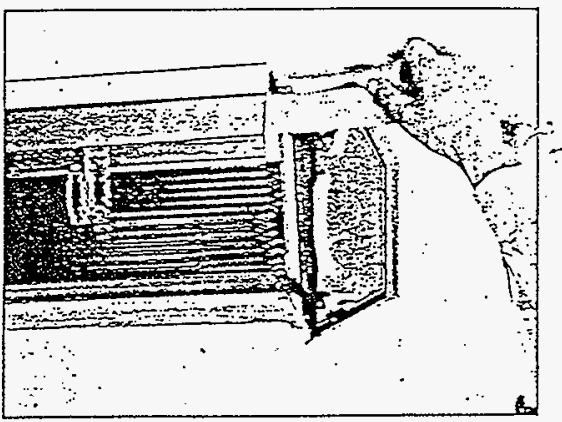

Internally mounted uplight shield can be field installed or removed at any sme (SD-1 shown with 0-36).

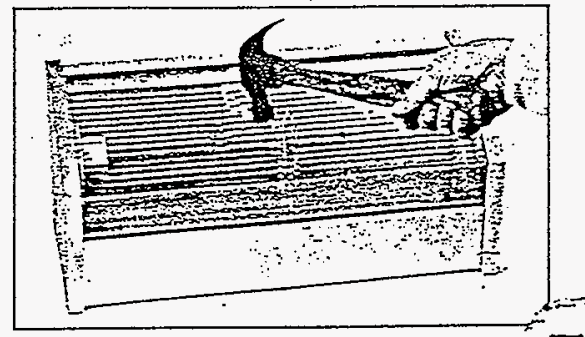

Polycarbonate lens resists breakage: Absence of ultraviolet in L.P.S. source eliminates lens embrittlement and yellowing over time. 
Hoțuas

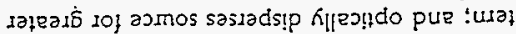
-jed ueaq fua!rya ofu! ly

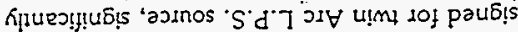
-ap Kiaspard amionus sual ग!eusud anbiu

- uotieutun!!!

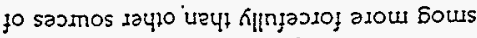

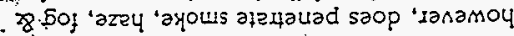

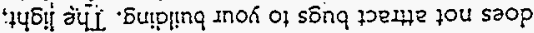

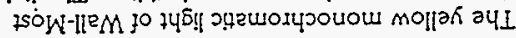
$\therefore$ Kpaxp pama!n uaym uana

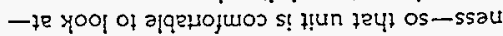

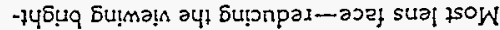

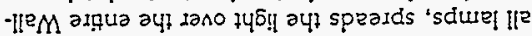
lof 'az!s Je snou!un buo] -salou $150 \%$-llOM louon!pp

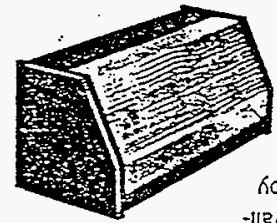

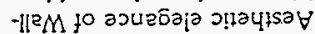

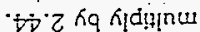

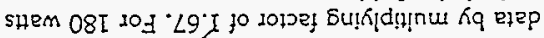

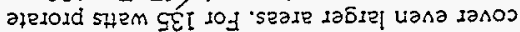

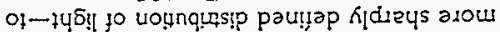

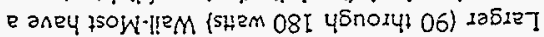

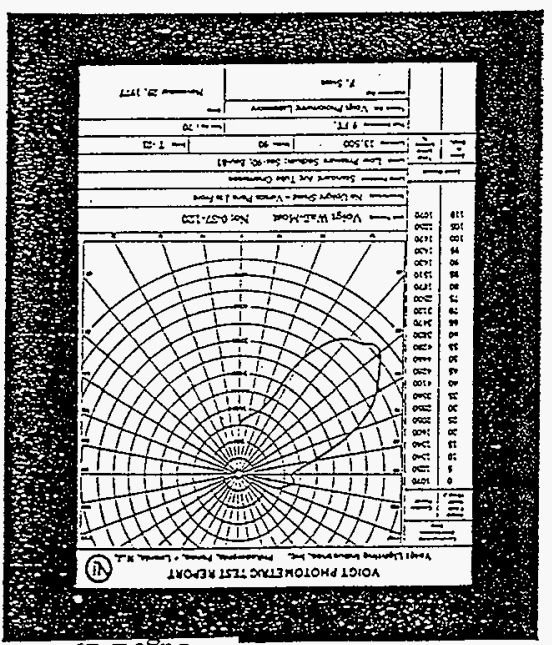
$6 z-g$ 20ए d

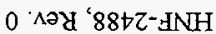

Kypads hiduts paxis -ap se saysiuif 20 [0s

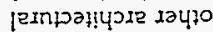
do - ypelq ut suo!sian אq paวueyua aq ueว $450 \mathrm{~W}$ -leM jo anuebaja suayisa $\cdot\left(926070^{\circ} \circ \mathrm{N}\right.$

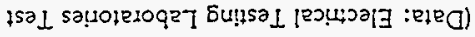

...: dure 7 unipos anssadd mo 7 Hem

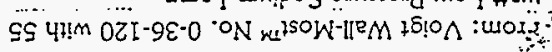
.0-, GI - I4biaH Sununow

t!un abuts wodj punoio uo sa!puejto 3 jo ma! $\Lambda$ dol

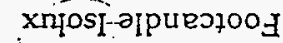

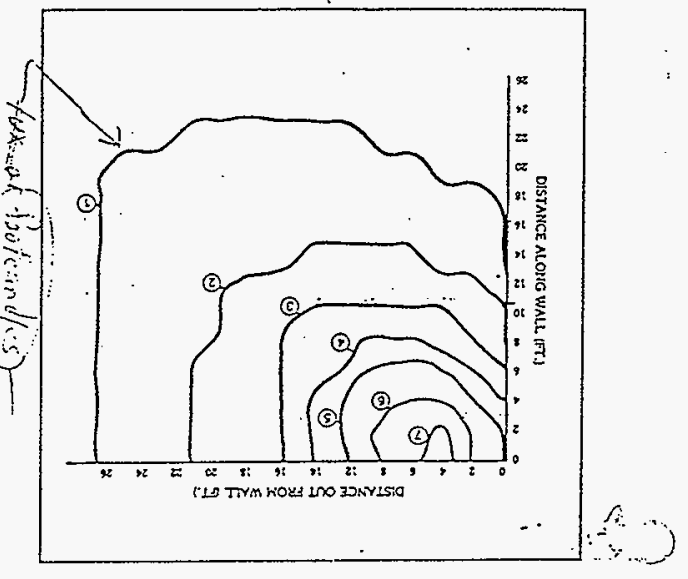

's!em sumunow pue s5upping of tuaszipe seare abie jo abe -janos sana!ỵja jsow-lle $M$ jo peasds weaq ap!M

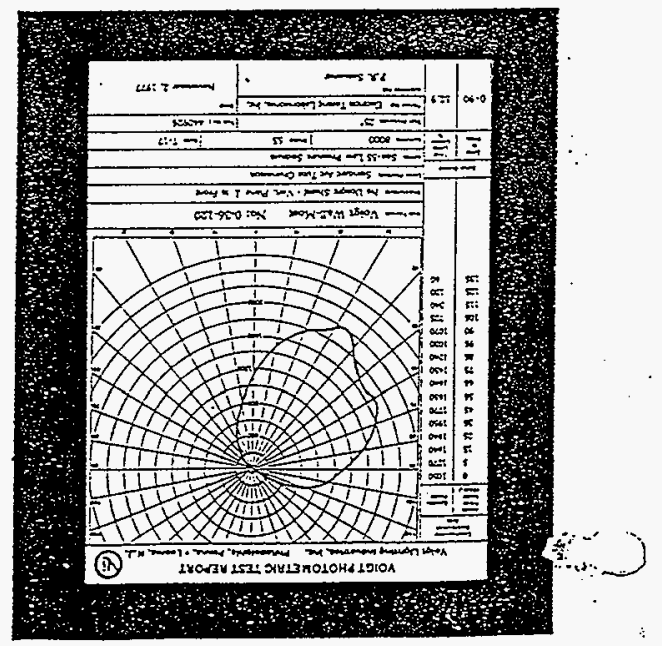


Lamp Specifications and Ordering

Information $n=1$

\begin{tabular}{|c|c|c|c|c|}
\hline $\begin{array}{l}\text { CATALOG: } \\
\text { NUMBER: }\end{array}$ & {$\left[\begin{array}{l}\therefore: \ldots \\
\hdashline \text { Wara }\end{array}\right.$} & Rated Life & $\begin{array}{c}\text { Inityal \& Maintained } \\
\text { Luman Oupur }\end{array}$ & $\begin{array}{l}\text { Max OA Length } \\
\therefore \text { io inchex }\end{array}$ \\
\hline SOX-18. $\because$ & $\because 18$ & 10,000 & $\therefore 1,800 \quad \because$ & $\because 81 / 2$ \\
\hline $50 \times .35:$ & $\because+35$ & 1. $18,000=$ & $\because 4,800$ & $\because 12-3 / 16$ \\
\hline $50 \times-55 \cdot:$ & 55 & $18,000^{\circ}$ & $\therefore \quad \because \because 8,000 \quad \because \because$ & $E: 16-3 / 4$ \\
\hline sox.90 & $\because \because 90$ & $-18,000$ & $\therefore: 13,500 \quad \therefore$ & $\cdots=20-3 / 4^{\circ}$ \\
\hline $50 \times-135$ & $\because 135$ & 18,000 & $\because \because 22,500: \because=$ & $\therefore \div 30-1 / 2$ \\
\hline $50 \times-180:$ & 180 & 18,000 & $\therefore 33,000 \quad \therefore$ & $\because \because \div 44 / 8$ \\
\hline
\end{tabular}

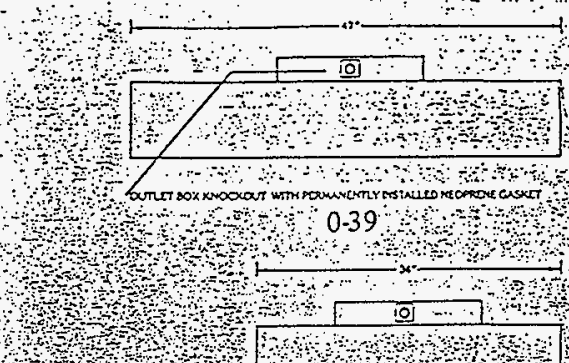

Table of Electrical Characteristics for Wall-Most

\begin{tabular}{|c|c|c|c|c|c|}
\hline $\lim _{s \rightarrow n}$ & 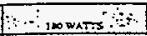 & $1+\therefore$ isimation & $\because$ xwatTS: & $\because \cdots$ मेखाल $\because$ & $\therefore=\because$ \#wATS \\
\hline Vomentrons & 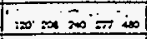 & $f_{1020} 200$ & $1: 2=000$ & 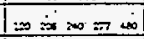 & 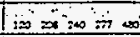 \\
\hline 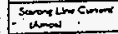 & $\because 2.0$ s.:5 1.00 .250 .5 & $1.11 .000100 \mathrm{cos}$ & 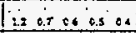 & lo.s5 ess ous cas oj & 6.8040 .40050 .2 \\
\hline entures & LS L.is $0.95 c E$ os & 140.50 .0000 .4 & l., 6 \& $\$ 90$ & Tow cos o.st $0.20 . ;$ & lo.se $0=0270.200 .14$ \\
\hline Promporosed & 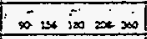 & $* 114=23$ & $\omega: 14: 2 z$ iss $=0$ & 46.:14:12 15: & $4=x M 13$ \\
\hline Don & $\infty . \infty+\infty$ & 0000 & 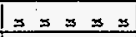 & $x=4 \leq x$ & $\approx z \leq z \leq$ \\
\hline Tention & $=0 \Rightarrow 0=0$ & די & Is: & $\infty \quad \infty \quad \infty \quad \infty \quad \infty$ & $\infty . \infty \infty$ \\
\hline Dime & $2=\infty 8$ & $0=x<$ & i. $20 \times 5$ & $0-64$ & $a-x<3$ \\
\hline 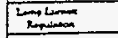 & : & . & $3: 58.5$ & Mnem & $:$ \\
\hline Suritimas & $=0-5$ & & $s=t-\infty$ & S & \\
\hline
\end{tabular}

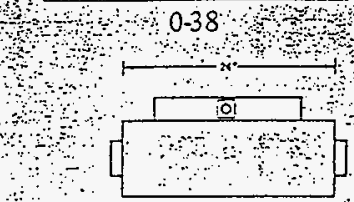

$0-37$

Basic Wail-Most

Specification and Ordering Information

\begin{tabular}{|c|c|c|c|c|c|c|c|c|}
\hline \multirow{2}{*}{$\begin{array}{l}\text { CATALOG } \\
\text { NUMBER }\end{array}$} & \multirow{2}{*}{$\begin{array}{c}\text { LP.S. } \\
\text { Nomisil } \\
\text { Lmpwata }\end{array}$} & \multirow{2}{*}{$\begin{array}{l}\text { Frost Vire } \\
\text { Suhowerte }\end{array}$} & \multicolumn{5}{|c|}{$\begin{array}{l}\text { Dimerestione } \\
\text { Wlich }\end{array}$} & \multirow{2}{*}{$\begin{array}{l}\text { Aprox. } \\
\text { Weght } \\
\text { LE. }\end{array}$} \\
\hline & & & $A$ & B & c & D & & \\
\hline $0-34000$ & $\begin{array}{l}. \\
18 \\
\ddots\end{array}$ & j. & 10 & 8 & - & - & 8 & 15 \\
\hline $\begin{array}{r}\because \because \because \because: 0 \\
0-36-000= \\
\therefore \therefore\end{array}$ & $\begin{array}{l}55 \\
\text { OR } \\
35 \\
\end{array}$ & & 20 & 18 & - & - & 8 & $21:$ \\
\hline $\begin{array}{c}3 \ldots . . \\
0-37-000 * \\
\because \because \ldots\end{array}$ & $\begin{array}{l}90 \\
\because \ldots \\
\end{array}$ & & 24 & 8 & $13 \%$ & 173 & \begin{tabular}{c}
8 \\
\hdashline \\
\hdashline
\end{tabular} & 31. \\
\hline 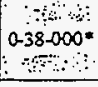 & {$\left[\begin{array}{c}\because \\
135 \\
\because \cdots\end{array}\right.$} & $\begin{array}{l}7 \\
0 \\
4\end{array}$ & 34 & 8 & $13 \div$ & $17 \%$ & $\begin{array}{l}\because \\
8 \\
8\end{array}$ & $\begin{array}{c}\because \\
39 \\
:\end{array}$ \\
\hline $\begin{array}{l}0.000 \\
0.39-000 \\
00\end{array}$ & 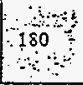 & 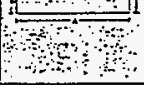 & 47 & 8 & $\begin{array}{c}\because \\
13 \div \\
\vdots\end{array}$ & $\begin{array}{c}\vdots \\
17 \div 3 \\
\vdots \\
\end{array}$ & $\mid \begin{array}{c}\because \\
8 \% \\
\therefore\end{array}$ & $\begin{array}{r}0 . \\
44 \\
\because \because \\
\therefore\end{array}$ \\
\hline
\end{tabular}

- Spect valage requited: $120,208,240,277.0 \times 480$ Le., No, 0.36-120.

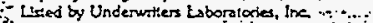

$$
\therefore
$$

Unis any LEEW label.

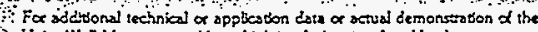

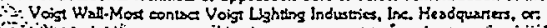

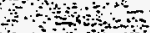

and
O HNF-2488, Rev. 0
Page B-30

(1i) Voigt Lighling Industries, Inc.

Wail-Most with exposed portions wholly made of extruded and cast aluminum and trensparant polycarbonate lens is the standard for strength and durability in outdoor wall mounted luminaires.

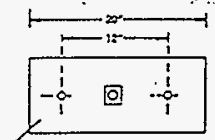

Optional Accessories

$0-36$

\begin{tabular}{|c|c|}
\hline $\begin{array}{l}\text { CATALOG } \\
\text { NUABER } \\
\text { SUFFDX }\end{array}$ & Decciption \\
\hline PR & Turst-Lock Pholocell Receptacle \\
\hline PI $\therefore$ & Intemally Mounted Photocell (120 volts on'y) \\
\hline MULT & Mult-Tap Ballas (120, 208, $244 \& 277$ volts) \\
\hline $\mathrm{NB}:=$ & Unit without ballast to allow remote mounting \\
\hline$\therefore$ ES & $\begin{array}{l}\text { Emergency Lighting Socket lor } 15 \text { watt } \\
\text { Bayone Base, T-7 lnc. Lamp }\end{array}$ \\
\hline 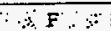 & Single Fuse \\
\hline$\because$ FF & Double Fuse \\
\hline BLACK & Black Painied outside finish \\
\hline COLOR & Painied Finish-specify color $\therefore \quad \therefore$ \\
\hline. $\operatorname{TP} \because \because$ & Vandal Resistant, Tamper-Piool Scews " " I! \\
\hline SD.1 : & Intemal Shield for $0-36$ \\
\hline SD.2: & Intems Shield for $0-37 \quad \cdots \quad \because \ldots$ \\
\hline SD-3 & Internal Shield fo: 0.38 \\
\hline SD-4 & Internal Shield for 0-39 \\
\hline
\end{tabular}

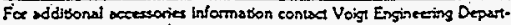
ment Cos for apjonal accessories avaldsble on reques.
Hasdquarters Location 135 For Lee Rd.

Leonit. N.J. 07605

$20 !-461 \cdot 2493$
Manufacuring Locstion

Phibciclphia, Penm. 19121 1636 No. Cariste $5 t$

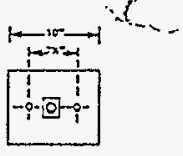

$0-34$ 


\section{F/24 Comfort heaters}

\section{22668 SUP.2L Chromalox.}

SHT. $201-205$ CALC.W320.31-015

Bldg.

mo24

ATTACHMGNT: J

\section{Wall mounted convection heater}

s.t. 1 of 4

0.5 to $5.0 \mathrm{~kW}$
120 10 $600 \mathrm{~V}$
1 \& 3 phase
24,36 \& $48 \mathrm{ln}$. width
U.t. Listed
Type HCH

Applicatlons

D A ruoged, reliable industrial con. rection healer cesigned lor easy inslallation in hard-use areas such as entranceways, staimells, guard shecks or other isolated builcings.

a ideal for cold spols in olices or plants.

\section{Foatures}

Built-in tharmostat $\left(55^{\circ} \mathrm{F}\right.$ to $105^{\circ} \mathrm{F}$ with ovenemperature cutout and choice of either automalic reset (standard) or menual reset (oplional).

Easy electrical hookup - ierminal blocks are standard.

Bollt in contactor supplied with all 208V and $240 \mathrm{~V} 3$. phase healers.

Transformer, transformer fusing and bullinn contacior supplied on all hee:ors rated $480 \mathrm{~V}$ and above.

Hoary gauge (H18) steel caso with zinc chromale primer and neutral gray baxed on finist.

Rugged shock proot steel fintube oloments with furnace brazed fins.

Additonal ratings avallablo. Please contact your nearest Chromalox factory tepresenlative.

Specify: Quantity, catalog ro., PCN. yolis, walls, phase, process air healers.

EEQHEE R. EHARL, WH.

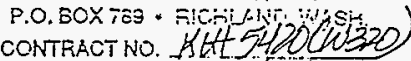
TRANSIATTAL NC. 414

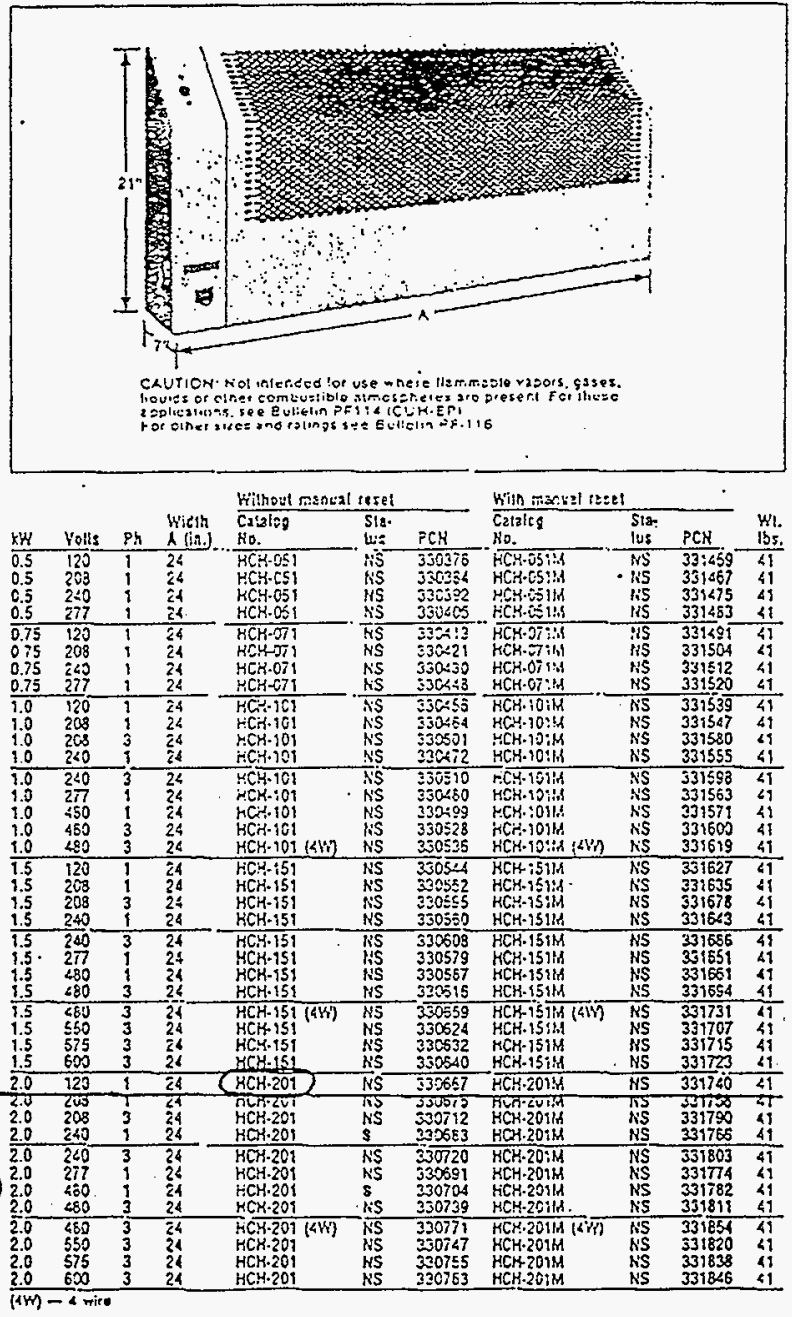

HNF-2488, Rev. 0

Page B-31

$$
3062 / 234 \% 9
$$




\section{Chromalox}

\section{Installotion, Operotion and RENEWAL PRRTS IDEHTIFICATIOH}

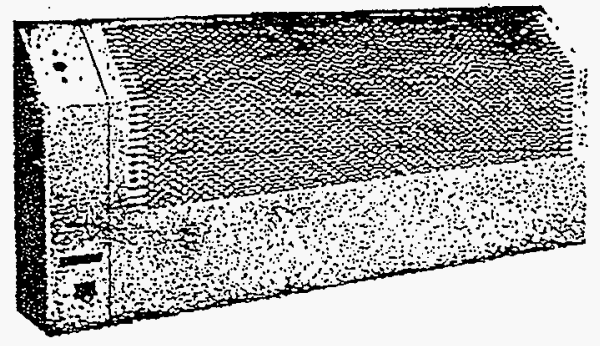

$$
\begin{gathered}
\text { CALC. W320-31-015 } \\
\text { ATTACHMFNT: J. } \\
\text { SH. } 2 \text { of } 4
\end{gathered}
$$

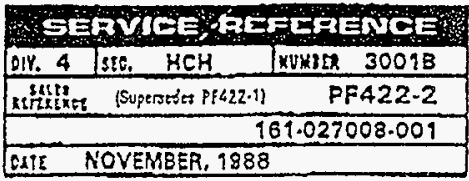

\section{Type HCH Convection Heater}

NOTICE: Cereifully remora heater from earoon and check for shippping domego. Any damage chim $x$ should be entered inmedialoly with tho. cartier.

CAUTION: Thix themer ts not Imiended for crse in hatardous almospherss nhere hommsblo rapors, gases, liquits, or otiar combustible e:mosphores are present as defined in the Ne. tionst Eloatric Cote. Failure to comply can. result in explosion of $\mathrm{Hr}$.

\begin{tabular}{|c|c|c|c|c|c|}
\hline \multirow{2}{*}{ Lumber } & \multirow{2}{*}{ (tos yotust } & \multirow[b]{2}{*}{ Natifte } & \multirow[b]{2}{*}{ mise } & \multicolumn{2}{|c|}{ Imensing - imshes } \\
\hline & & & & 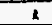 & 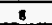 \\
\hline Rerrost & 21000027 & $5 \infty$ & 2 & \multirow{10}{*}{$x$} & \multirow{10}{*}{ is:s } \\
\hline HES\$71 & $\begin{array}{l}1 \times 0,20 \% \\
2<0 \text { or } 2: 7\end{array}$ & so & 1 & & \\
\hline \multirow[b]{2}{*}{ Mex.10! } & 1200227 & \multirow{2}{*}{2000} & $I$ & & \\
\hline & $205.210 * 110$ & & $\operatorname{Tat}$ & & \\
\hline \multirow{3}{*}{ rex-15: } & $120 \times 277$ & \multirow{3}{*}{8500} & $\frac{1}{1}$ & & \\
\hline & $208.265 \times 480$ & & 1013 & & \\
\hline & 350.575 or 500 & & 3 & & \\
\hline & $180+12 \pi$ & \multirow{3}{*}{$\cos$} & $I$ & & \\
\hline$x=x \geq 2:$ & 128,240 or 485 & & is 3 & & \\
\hline & $990.5 T+0 \pi 100$ & & 3 & & \\
\hline \multirow{3}{*}{ 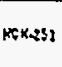 } & $1 x+12 \pi$ & \multirow{3}{*}{$2 \infty$} & 1 & \multirow{3}{*}{35} & \multirow{3}{*}{274} \\
\hline & $2 C B .200$ Df $\angle 80$ & & 1013 & & \\
\hline & 550,575 ot 000 & & 3 & & \\
\hline
\end{tabular}

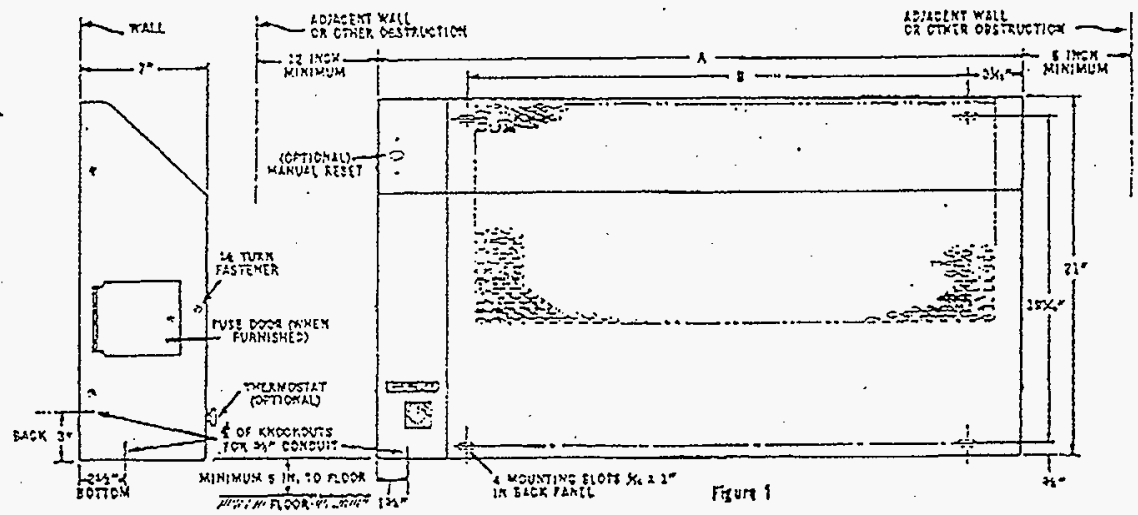

\begin{tabular}{|c|c|c|c|c|c|}
\hline \multirow{2}{*}{$\underset{x y m>\pi}{\operatorname{cxtan}}$} & \multirow{2}{*}{ (n) rotore 40} & \multirow[b]{2}{*}{ 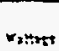 } & \multirow[b]{2}{*}{ Phost } & \multicolumn{2}{|c|}{ Eimensimx - isents } \\
\hline & & & & i & $\geq$ \\
\hline \multirow{3}{*}{ mo.rel } & 277 & & 1 & \multirow{6}{*}{26} & \multirow{6}{*}{2736} \\
\hline & 208,2200180 & $2 \times 0$ & $t \operatorname{ter} 3$ & & \\
\hline & 390,575 प1 595 & & 3 & & \\
\hline \multirow{3}{*}{ Wexass: } & 2.7 & \multirow{3}{*}{3800} & 3 & & \\
\hline & 200,200 of 1000 & & det 3 & & \\
\hline & $500,5 \pi, 01000$ & & 3 & & \\
\hline \multirow{3}{*}{ HEX-4OZ } & 277 & \multirow{3}{*}{1000} & 2 & \multirow{9}{*}{ at } & \multirow{9}{*}{ ar } \\
\hline & 201,24008480 & & 2003 & & \\
\hline & 590,575 of 000 & & 3 & & \\
\hline \multirow{3}{*}{ MSK-S1 } & 277 & \multirow{3}{*}{$\operatorname{css}$} & 1 & & \\
\hline & 202,20001460 & & 1 or 3 & & \\
\hline & $50,37501000$. & & 3 & & \\
\hline \multirow{3}{*}{ 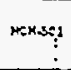 } & $2 \pi$ & \multirow{3}{*}{3000} & 1 & & \\
\hline & $2082100+210$ & & $1=13$ & & \\
\hline & 350,143 or 35 & & 3 & & \\
\hline
\end{tabular}

Spesificetions - Teble A

HNF-2488, Rev. 0

Page B-32 
CAUTION: Mazerd of ofperto stoct. OStrommer off comer broro instatifing hastar.

1. Locar on reticel wall wiht knch of tester pasitionod forizontilly.

2. When Niecting a mouning lecsion, the following mintmum distents must otserved:

*. Six $\left(6^{7}\right)$ inches from borton of imsier to floor to sllow for

zoguses alr fow through the hesier.

b. Sis 107 inches from tall of cher obstrution 10 right side of hecter to allow for ecses; to X rum festerers.

c. Trajye (12) inches from wall or etros obsiruction to lef siot of iealer 10 aliow for acoss 10 concols end wire entry. 3. Aroid mourting teater in a sixes such mounting interferes

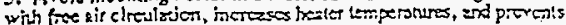
groper chemostat operation.

4. Remove from cove by siving two fasterers on tight end of इन

CAUTION: Hazerd of electic shack. AnT instlletion involying foctito heators must be grourtod to earth to allothato shock tiazerd.

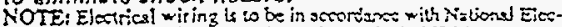

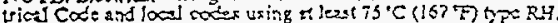
IHW or equivalent irsulated conduciers.

1. Eloctried wiring can be brought has heater through $*$ " knockout locaros either in back penel or borem of laf herd end of heater (wiring compotement).

Miring Diegrotaz - Tabies

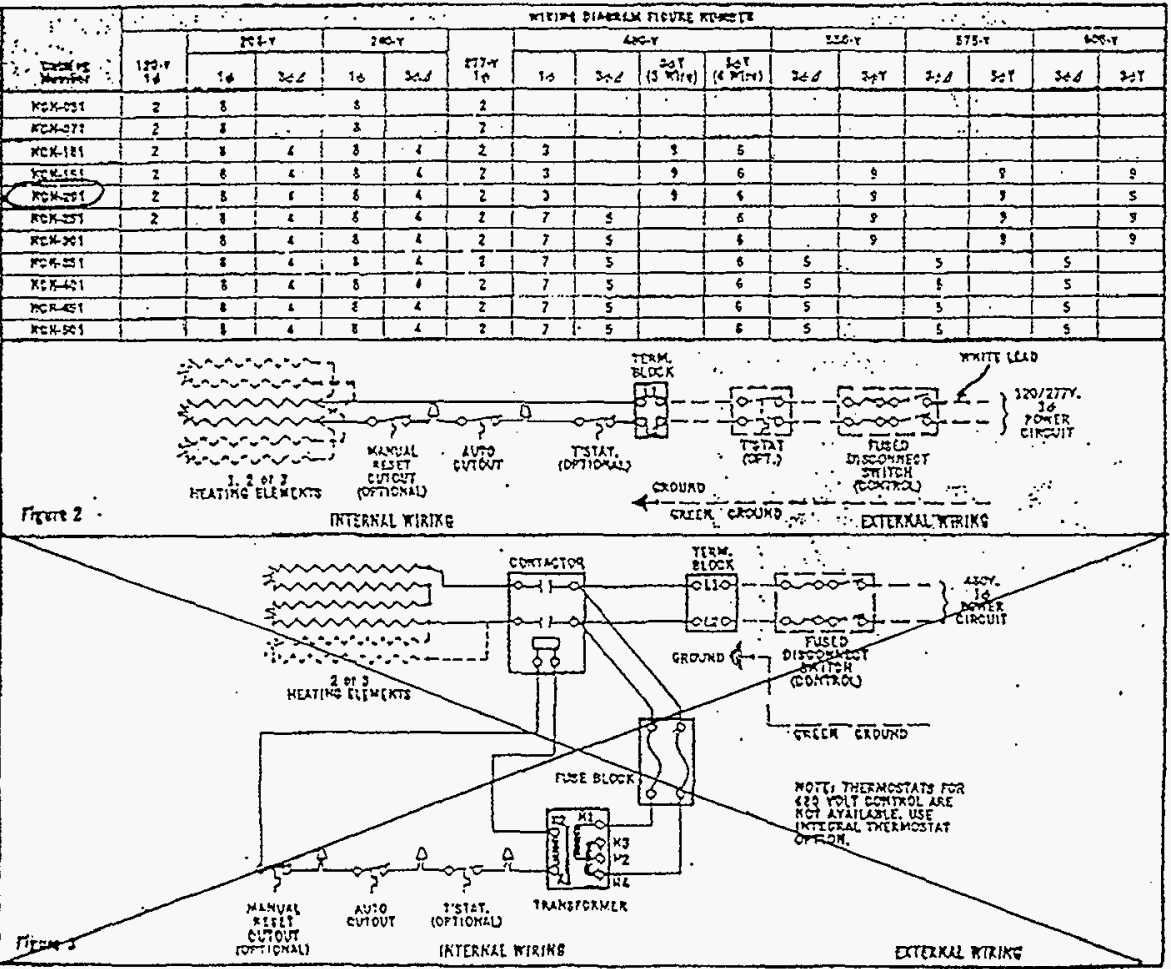

HNF-2488, Rev. 0

CALC. N $320-31-015$

Page B-33 heater 'A turn then slicing coves approximstely $1^{*}$ to tighe, then JiRine.

5. Ait the sorrect height for the top of the heser, drew a pexil line on the wall, parillel to the noor.

6. Using simensions shown in Figurs 1, watk the mounting sict location on the wall

7. Mount better to the wall by using festeners (inot furmixhed) to

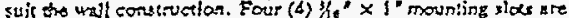
provided in ineter beck pevel. NOTEt If wall verface is not fil.

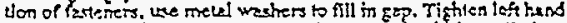
fisterers trurely. The tight hand futmers should be puljed up snug to allow for troremon during operatica lo syoid exparsion noise.

8. Replace cover and tighten bien taxteness. rerutring in gep between rear cose axd walt in excess of $K^{*}$ of loc2.

2. Grenting conducter with aren insulation, should be veared isto grounding lug locesed in wising comparment.

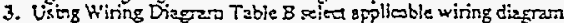
(Fievre 2.5) for preper method of connecting hester.

4. Tuo or tert Type HCH hesiers ray be controlled by a com-

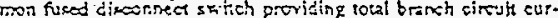

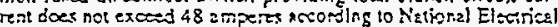
rent doeste

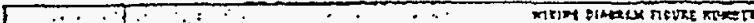




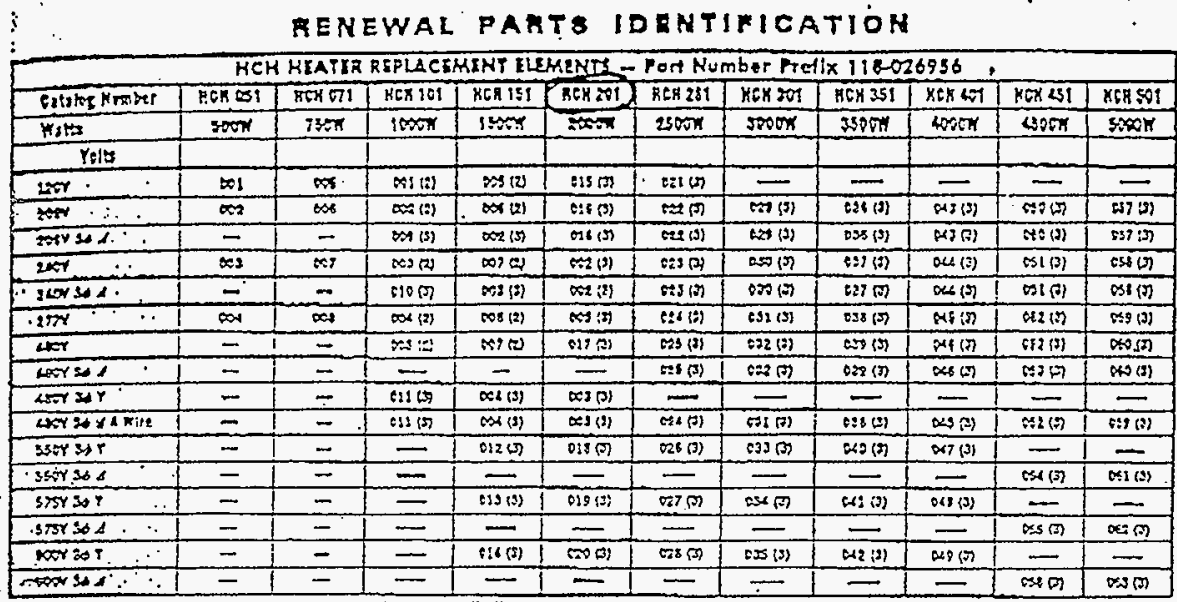

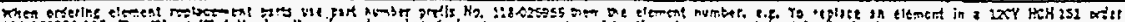

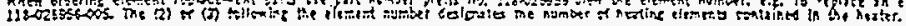

\begin{tabular}{|c|c|}
\hline \multicolumn{2}{|c|}{ AUTOMATHE CUTIOFF RIPLACEMETT } \\
\hline IET HCX Bevters & ist $x_{t m i n t}$ \\
\hline 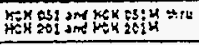 & $x+2-2413-x:$ \\
\hline 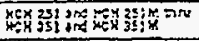 & $300-\cos 13-002$ \\
\hline 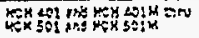 & $33 \times-5245130 \times 9$ \\
\hline
\end{tabular}

\begin{tabular}{|c|c|}
\hline \multicolumn{2}{|c|}{ REPUCEMENT CONTACTOR } \\
\hline For KCH Perors ond & Pret Xater \\
\hline Lor Eerde past & 072-45-2500-COA \\
\hline $486 y$ :bra $6 x y 3$ those & 072.0823509 .072 \\
\hline EsY and ilat forte these & $0120 \leq 2 \leq 54001$ \\
\hline Tosy m a cher 3 oteat & 072.052550 .563 \\
\hline
\end{tabular}

\begin{tabular}{|c|c|}
\hline \multicolumn{2}{|c|}{ REPLACEMENT TRANSFORMER } \\
\hline For KEN Hertefs roted & Ftit Kamer \\
\hline$\angle 809$ & 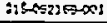 \\
\hline 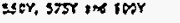 & 3isorsitstrie \\
\hline
\end{tabular}

\begin{tabular}{|c|c|}
\hline \multicolumn{2}{|c|}{ THERMOETAT REPLACEHEKT } \\
\hline For HCX Axts & Part $x_{2}$ mitor \\
\hline If nixys & $3 \times 0.9157001$ \\
\hline 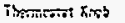 & 10051208.601 \\
\hline
\end{tabular}

\begin{tabular}{|c|c|}
\hline \multicolumn{2}{|c|}{$\begin{array}{l}\text { REPLACEMENT FUSES FOR ALI TRANSFORKERS - } \\
\text { THO REQUIRED }\end{array}$} \\
\hline For RCK Healers nies & im Krabt \\
\hline eser, ssor, stey and cost & $: 21.0077(3<11$ \\
\hline
\end{tabular}

\begin{tabular}{|c|c|}
\hline \multicolumn{2}{|c|}{ MANUAL TEHPERATURE CONTKOL REPLACEMENT } \\
\hline XCh on Hester & Pit Kuraber \\
\hline H. & soginisei-oss \\
\hline$x=251 \% \operatorname{man} x=x$ & 300-i1:16:002 \\
\hline $40 \times<01 k$ then $\pi 0 x \operatorname{sos} M$ & 200.12764 .004 \\
\hline
\end{tabular}

\section{LIMITED WARRANTY FOR CHROMALOX INDUSTRIAL PRODUCTS}

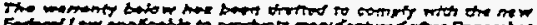

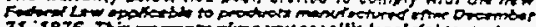

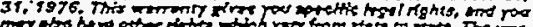

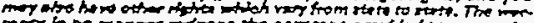

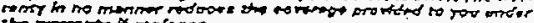
tho wortaris if repreces.

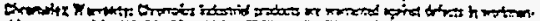

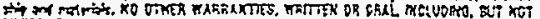

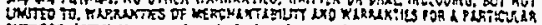

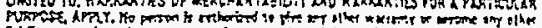

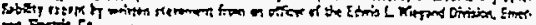
Enctie Co.

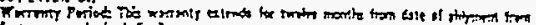

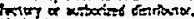

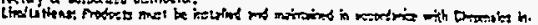

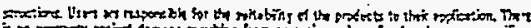

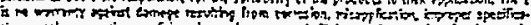
ton $x \mathrm{gth}$ ow

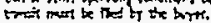

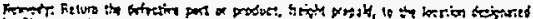

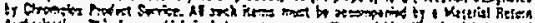

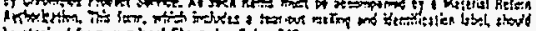

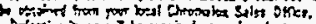

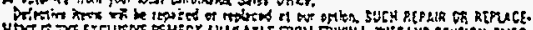

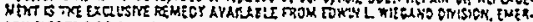

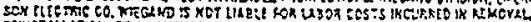

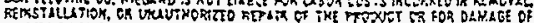

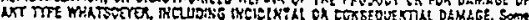

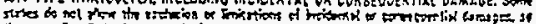

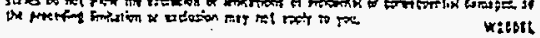

EOVIN L WIEBANO DVSION EMERSON ELECTRIC CO.

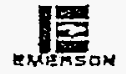

CALC. W320.31-015 ATTA CHMSNT: $J$
sH, 4 of 4

HNF-2488, Rev. 0

Page B-34 


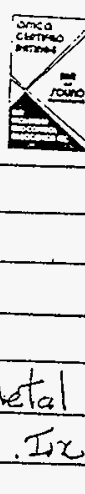

Dimensions given on this sheet are correct within limits suitable for normal installation requirements.

DIRECT DRIVE WIRTERAPAL L SAFETY PLUG SWITCH ON PWIIITHRU 200

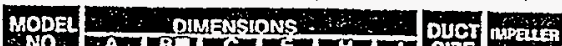

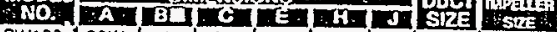
\begin{tabular}{|l|l|l|l|l|l|l|l|l|}
\hline PW100 & $201 / 11$ & 11 & 3 & 12 & 13 & 11 & 10 & $9 \%$ \\
\hline PW110 & $201 \%$ & 11 & 3 & 12 & 13 & 11 & 10 & $1 \%$ \\
\hline
\end{tabular}

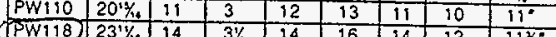
\begin{tabular}{|c|c|c|c|c|c|c|c|c|}
\hline PW118) & $231 / 6$ & 14 & $3 \%$ & 14 & 16 & 14 & 12 & $11 \%$ \\
\hline PW126 & $231 / 4$ & 14 & $3 \%$ & 14 & 16 & 14 & 12 & $12 \%$ \\
\hline
\end{tabular}

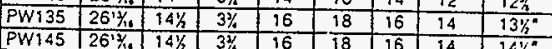
\begin{tabular}{|l|l|l|l|l|l|l|l|l|}
\hline PW145 & $26^{1} / / 4$ & $14 / /$ & $3 \%$ & 16 & 18 & 16 & 14 & $14 \%^{\circ}$ \\
\hline PW163 & $30 \% / 2$ & $15 \%$ & 4 & 19 & 21 & 19 & 16 & $16 \%$ \\
\hline
\end{tabular} \begin{tabular}{|l|l|l|l|l|l|l|l|l|}
\hline PW171 & $30 \%$ & $15 \%$ & 4 & 19 & 21 & 19 & 16 & $16 \%$ \\
\hline$P W 200$ & $16 \%$ & 18 & 4 & 22 & 24 & 22 & 1 & $2 \%$ \\
\hline
\end{tabular} \begin{tabular}{|l|l|l|l|l|l|l|l|l|}
\hline PW200 & 40 & 18 & 4 & 22 & 24 & 22 & 18 & $20^{\circ}$ \\
\hline PWB200 & 40 & $18^{2}$ & 4 & 22 & 24 & 22 & 20 & $20^{\circ}$ \\
\hline
\end{tabular}

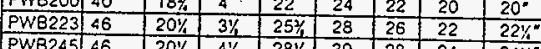

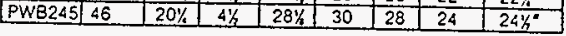
"ADO 4" fOR EXPLOSION PROOF ON PW FANS

WARMINQI DO NOT USe In HAZLRDOUS ENVJAONHENTS whore $12 \mathrm{~m}$

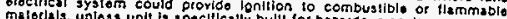
maidials, unless unit is spoclfically bulit for hazardous onvirontronis.

CAUTION! Guarde must be Installed when fan is within toach of porsonnat of within seven (7) foet of working lovel or when deemed sovisubio tor saloty.

BELT DRIVE

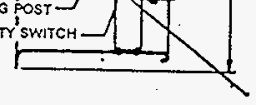

\section{FEATURES}

Aluminum housing and wheel with gauges from .050 to 125 ; sleel walt plate and recessed orifice, finished whth epoxy.

Backward curved non-overloading elrfolt im. peller, statically and dynamically balanced.

Hollow airfoil blades for quieter performance.

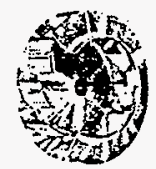

\section{LEOEND}

External drip ring prevents grease and othè contaminanis from running down wall.

Directs exhause aif away from wall.

All motors have lubricated ball bearings and are available in single or two speed. Models PW 100 and PW 110 have three speod motors.
O. Open (Dripproof)
EX. Explosion Proot 2S- Two Speed AW- Square Damper RD. Found Damper GR. Wall Grille PWG. Inlet Guard

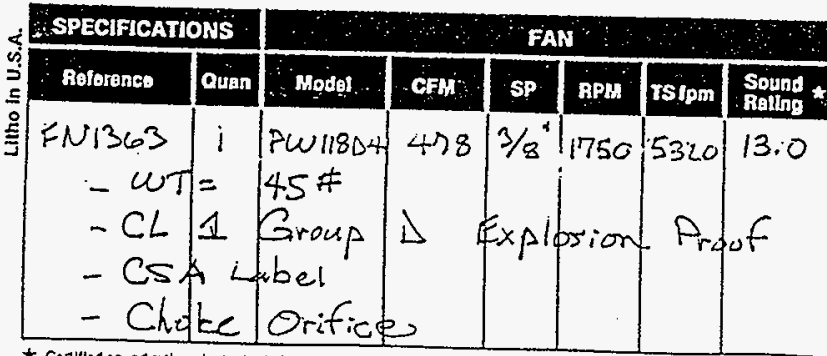

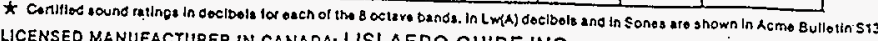
LICENSED MANUFACTURER IN CANADA: LISI AERO GUIDE INC., MONTREAL, PROV. QUE.

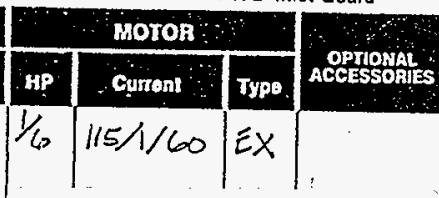

HNF-2488, Rev. 0

Page B-35 


\section{INSTALLATION \& MAINTENANCE INSTRUCTIONS CENTRI MASTER ${ }^{\circledR}$ MODELS PW \& PWB}

\section{RECEIVING AND INSPECTION}

1. Immediately upon receipt of a shipment, carefully inspect for damage and shortage. Turn impeller by hand to see that it turns ireely and does not bind. If any damage and/or shortage is detected or suspected the carrier must be asked to conduct an inspection. The consignee's representative should not accept shipment without a notation on the delivery receipt inclicating items not delivered or apparent extent of damage.

2. When a shipment is opened and damage is found which was not evident externafly (concealed camage), it is inandatcry that the consignee recuesi an immediate inspection by the carrier. Report damage to the carrier within 15 days. Failure to report damage within the above time limit will cause rejection of a claim.

HANDLING AND STORAGE

1. Units should be litted using a sling or platform. Whenever possible, fans should be stored indoors in clean, dry locations. If storage outdoors is necessary, fans should be protected against the elements and accumulation of dirt and moisture. Special care must be taken to keep motors and bearing assemblies dry and clean. See Acme Form 833, Proper Slorage of Acme Fans.

\section{INSTALLATION}

1. This unit has rotating parts and safety preceutions should be exercised during installation. operation and maintenance.

2. WARNING! DO NOT USE IN HAZARDOUS ENVIRONMENTS WHERE THE FAN'S ELECTRICAL SYSTEM COULD PROVIOE IGNITION TO COMBUSTIBLE OR FLAMMABLE MATERIALS. UNLESS UNIT IS BUILT SPECIFICALLY FOR THE ENVIRONMENT.

3. Provide a square opening in the wall equal to the outside dimensions of fan wallolate.

4. Slide the fan into the framed opening in the wall. Securely fasten with lag bolts or screws provided by the installer.

5. CAUTION: GUARDS MUST BE INSTALLED WHEN FAN IS WITHIN REACH OF PERSONNEL OR WITHIN SEVEN (7) FEET (2.134 m) OF WORKING LEVEL OR WHEN DEEMED ADVISABLE FOR SAFETY.

6. Turn centrifugal impeller by hand to make sure it rotates freely. If impeller hits orifice, adjust as follows:

Direct Driven Exhausters - Loosen set screws in impeller hub and move impeller back on motor shati. The impeller of the PW200 unit is attached to a sleeve which is attached to the motor shatt. Remove the wo socket head cap screws completely. This will allow the impeller to be removed from the shait.

Belt Driven Exhausters - The bearing support is slotted for up and down adjustment. Loosen bearing support bolts on both support channels and move bearing support up or down. If impeller continues to strike. move impeller and shah back. (See Maintenance, Section 7 for bearing replacement).

7. CAUTION Before proceeding. make sure electrical service to ian is locked in "OFF" position. Run wites through the internal wiring post to the motor, to safety disconnect switch if used. On Belt Oriven Exhausters leave enough slack in wiring to allow for motor movement when adjusting bell tension. Some fractional motors will have to be removed to make connection at terminal box on end of motor; remove bolts securing motor base to acjusting rails - do not take out moter bolts. Re-adjust belt tension.

8. All wiring should be in accordance with local ordinancas and the National Eleciric Code.

9. WARNING! Check voltage at the fan to see if it corresponds with the motor nameplate: high or low voltace can seriousiy damage the motor Extra care shcuid be taken when wiring two or inree speed motors since improper connections will camage motor and void motor warranty.

10. Operate under power and compare rotation with directional arrow. WARNING! Do not operate at speeds higher than shown in catalog for this equipment. Operation in the wrong direction will deliver air but will overload the motor to the extent of blowing fuses or overload protection and could seriously damage the motor. In the case of three phase motors, the direction can be changed by interchanging any two of the three motor leads. In the case of single phase motors. the reversing instructions will appear on the wiring diagram in the motor wiring compariment or on the molor.

\section{MAINTENANCE}

1. No spare parts are recommended for one year normal service.

2. CAUTION: Before proceeding, make sure electrical service to tan is locked in "OFF" position.

3. Impeller shaft bearings on Belt Driven Exhausters are prelubricated and sealed: no service required.

4. Motor bearings are prelubricated. Consult information printed on motor for lubrication instructions.

5. On Beit Driven Exhausters check belt tension after first 48 hours of operation and thereafter annually. Belt should depress its width when pressed firmiy inward at midway point between the pulleys. Too much tension will damage bearings; belt should be tight enough to prevent slippage. When replacing worn belt, replace motor pulley if "shoulder" is worn in groove. WARNING! Do not replace motor oulley with a larger diameter pulley. Do not replace the far pulley with one smaller in diameter. The pulley ratios are set so that the motor will not be overloaded.

6. If impeller shaft bearings need replacement, replace with bearings comparable to original equipment. install new bearings into neoprene rings, check correct position of impeller with orifice, position bearings in die formed recess and tighten set screws. Replace die formed bearing cap and tighten four bolts. NOTE: If locking collar type bearing is used, collar must first be positioned against inner race on bearing nearest impelier and turned in direction of impeller rotation with dritt pin and hammer until it locks. Locking collars must be on inboard (facing) sides of the bearings. Secure bearing to shaft with set screw. Lock and secure other bearing to shaft in same manner. If pillow block type bearings are used. slide bearings on to shaft to desired location and bolt bearing block securely to support base.

Slide shaft back and forth in secured bearing (do no: drive with hammer) and rotate to make certain it turns treely. Check correct position of impelfer with inlet orifice. Then secure bearings to shatt by tightening set screws. 


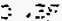

$\therefore \div \%$.
$20 y,-6, ? \div ?$

\section{EXPLODED VIEW OF FWIOO \& 110}

$C A \leftrightarrow$ W $320-31015$ ATTACHMENT:K M. 3 or 4

(5)

(8)

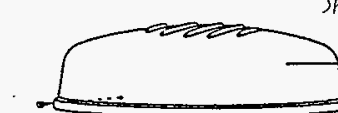

(1)
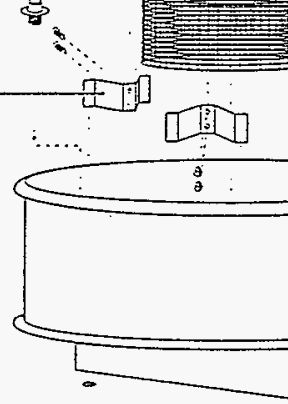

i]

(9)
, - EXPLODED VIEW OF PW $18-200$ $\because=x=x$

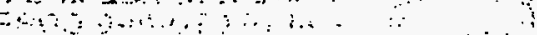

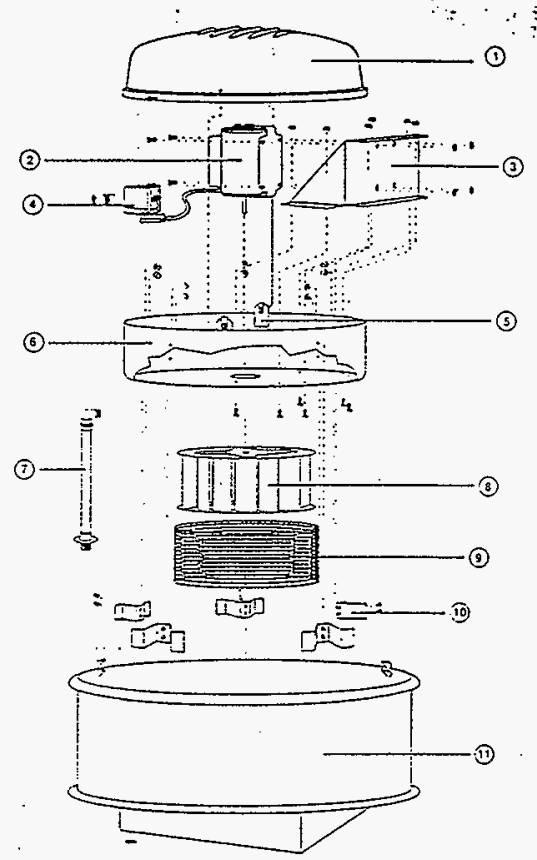

\begin{tabular}{|c|c|c|c|}
\hline \multicolumn{3}{|c|}{ PARTS LIST LEGEND } \\
\hline & NO. & OESCRIPTION & QTY \\
\hline & 1 & MOTOR ENCLOSURE COVER & 1 \\
\hline & 2 & MOTOR & 1 \\
\hline & 3 & MOTOR ENCLOSURE CLIPS & 2 \\
\hline & 4 & MOTOR ENCLOSURE & 1 \\
\hline & 5 & WIRING POST & 1 \\
\hline 1 & 6 & IMPELLER & 1 \\
\hline & 7 & BIRDSCREEN & 1 \\
\hline & 8 & MOTOR ENCLOSURE SUPPORTS & 3 \\
\hline & 9 & TUBE \& ORIFICE ASSEMBLY & 1 \\
\hline & & & 1 \\
\hline & & \\
\hline
\end{tabular}

\begin{tabular}{|c|c|c|}
\hline \multicolumn{1}{|c|}{ PARTS LIST LEGEND } & DESCRIPTION & OTY \\
\hline NO. & \multicolumn{1}{|c|}{ DT } & 1 \\
\hline 1 & MOTOR ENCLOSURE COVER & 1 \\
\hline 2 & MOTOR & 1 \\
\hline 3 & MOTOR BASE & 1 \\
\hline 4 & DISCONNECT SWITCH & 2 \\
\hline 5 & MOTOR ENCLOSURE CLIPS & 1 \\
\hline 6 & MOTOR ENCLOSURE & 1 \\
\hline 7 & WIRING POST & 1 \\
\hline 8 & IMPELLER & 1 \\
\hline 9 & BIRDSCREEN & 1 \\
\hline 10 & MOTOR ENCLOSURE SUPPORTS & 5 \\
\hline 11 & TUBE \& ORIFICE ASSEMBLY & 1 \\
\hline 1 & & \\
\hline
\end{tabular}


$\therefore$ EXPLODED VIEW OF PWB $:-$ :

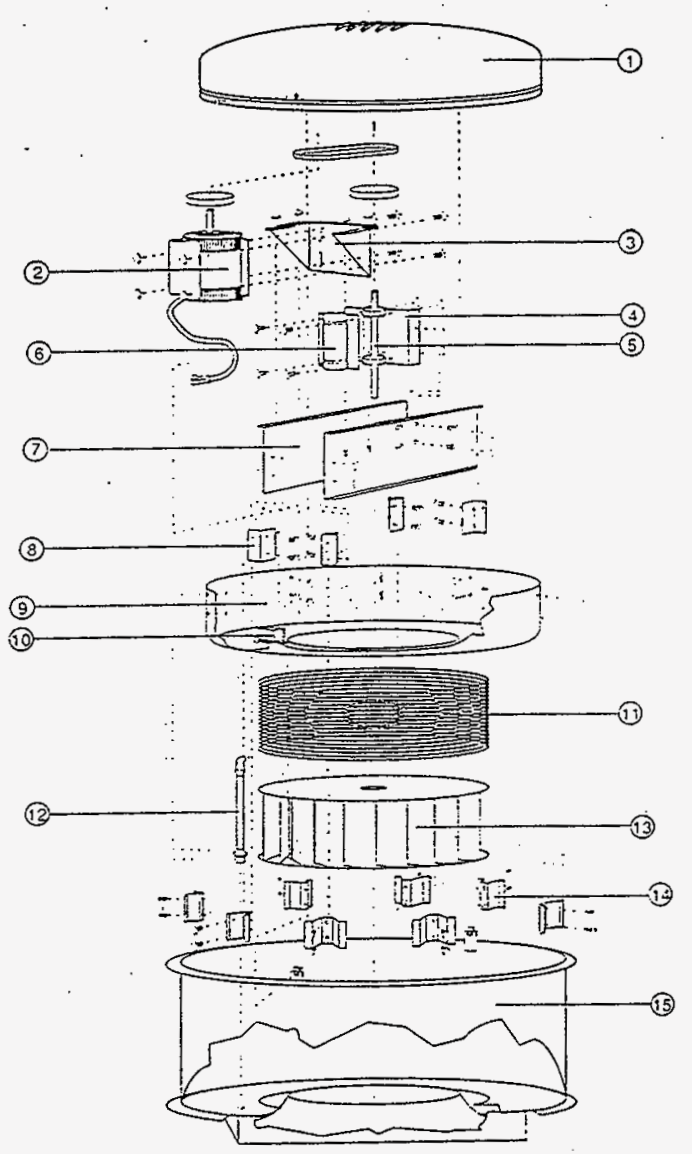

CALC. W $320.31-015$ ATTACḦMENT $=K$

SH. 4 of 4

PARTS LIST LEGEND

\begin{tabular}{|c|c|c|c|c|c|}
\hline NO.1 & DESCRIPTION & IQTY. & iNO.: & DESCRIPTION & QTY. \\
\hline 1 & MOTOR ENCLCSURE COVER & 1 & 9 & MOTOR ENCLOSURE & 1. \\
\hline 2 & MOTOR & 1 & 10 & DISCONNECT SWITCH & 1 \\
\hline 3 & MOTORBASE & 1 & 19 & BIROSCREEN & 1 \\
\hline 4 & BEARING BASE & $1 \cdot 1$ & 12 & WIRING POST & 1 \\
\hline 5 & SHAFT \& BEARING ASSEMELY & $i$ & 13 & IMPELLER & 1 \\
\hline 6 & BEARING CAP & $i 1$ & 14 & MOTOR ENCLOSURE SUPPORTS & 8 \\
\hline 7 & SUPPORT CHANNELS & 2 & 15 & TUBE \& ORIFICE ASSEMBLY & 1 \\
\hline 8 & CHANNEL SUPPORTS & 4 & 1 & & \\
\hline
\end{tabular}

HNF-2488, Rev. 0

Page B-38 
HNF-2488, Rev. 0

Page B-39

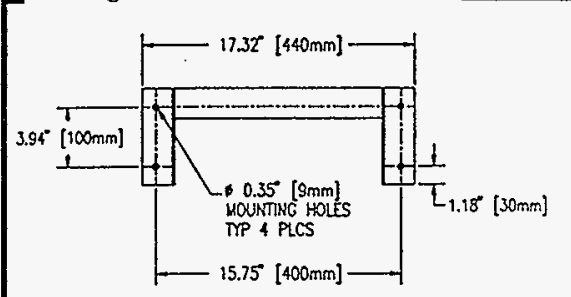

\begin{tabular}{|c|}
\hline SPECARCATONS \\
\hline 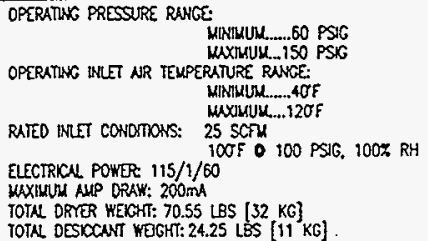 \\
\hline
\end{tabular}

ADPL DATE IIN REMSON

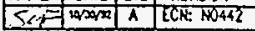
CALCW $320-31-015$ ATTACHMFNT: L

SH. 1 of 2

FLOR HOUNIING HOLE PATTERN DETAL

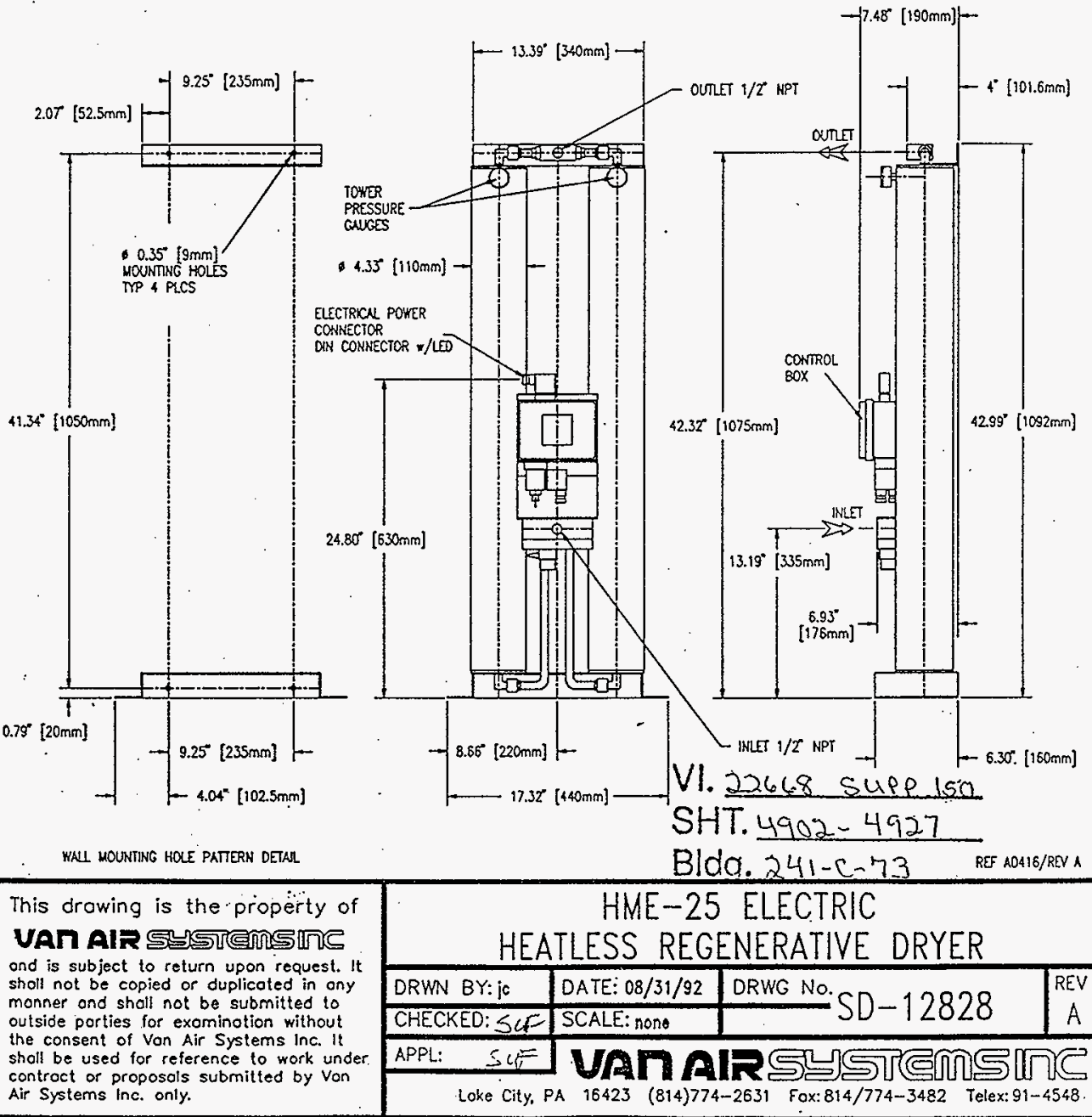




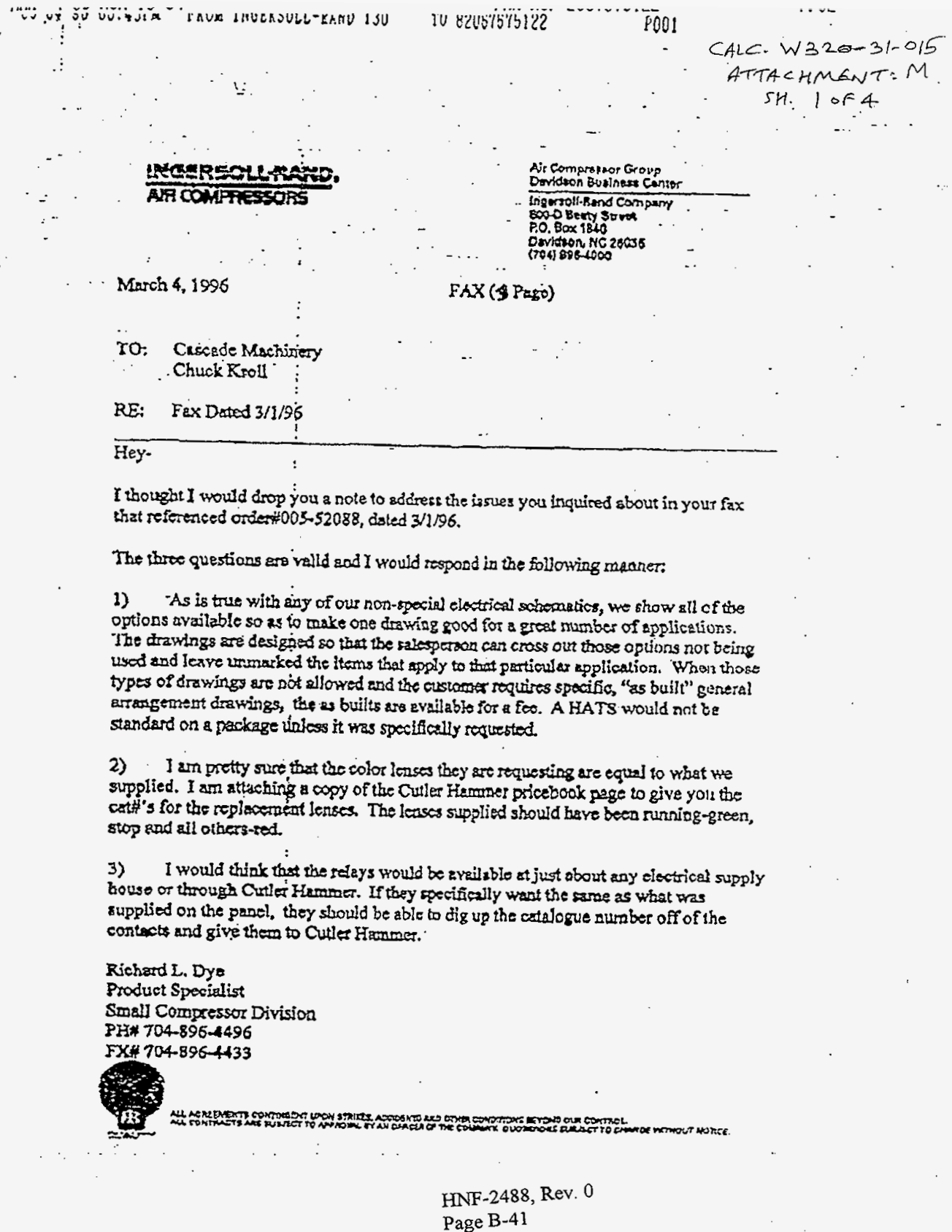


CALC.W320-31-015

ATTACHMENT: $M$

HNF-2488, Rev. 0

$5 H \cdot 2$ of 4 .

Page B-42

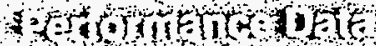

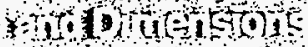

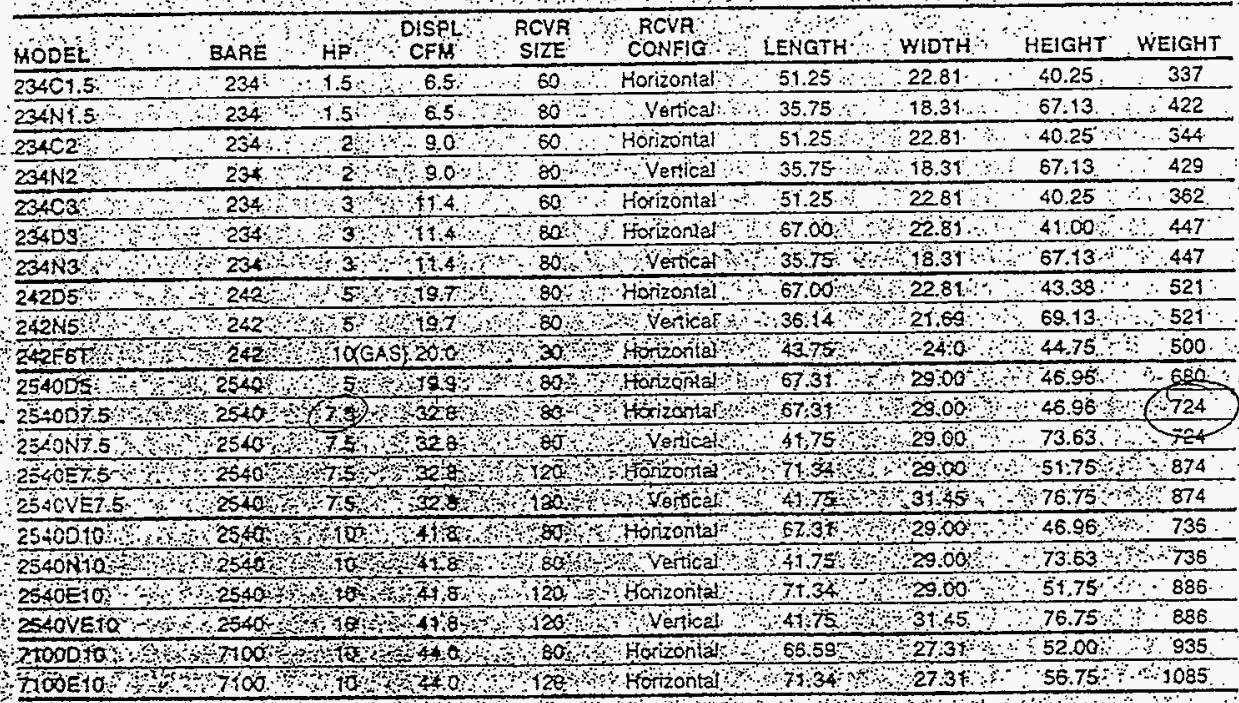

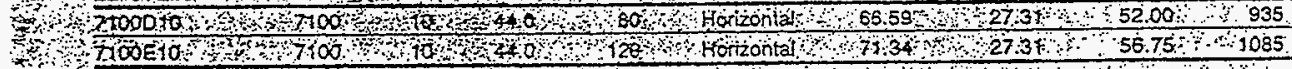

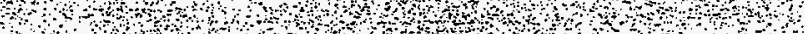

$3+,+3+2, ?$

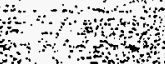

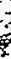

3

$\mathrm{HowhH}$

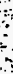

35.

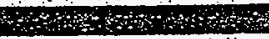

$6 \%$

$8+8$

$+42-2$ 


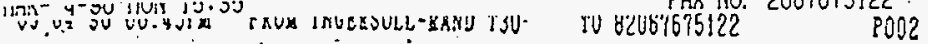

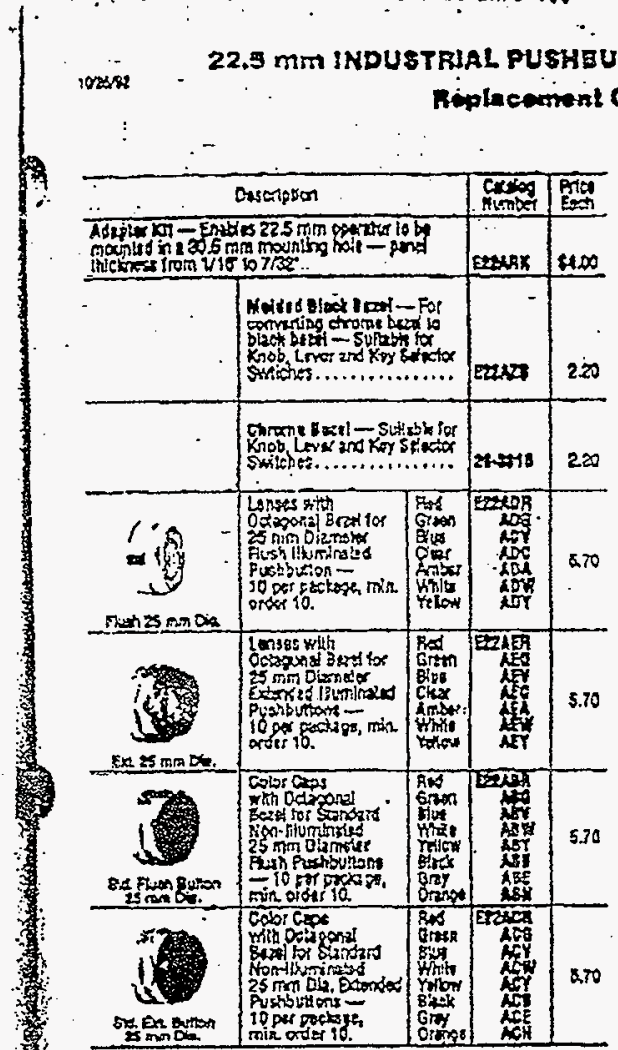

irsin - Hiplacement Cips and Lansex

ALE

E22

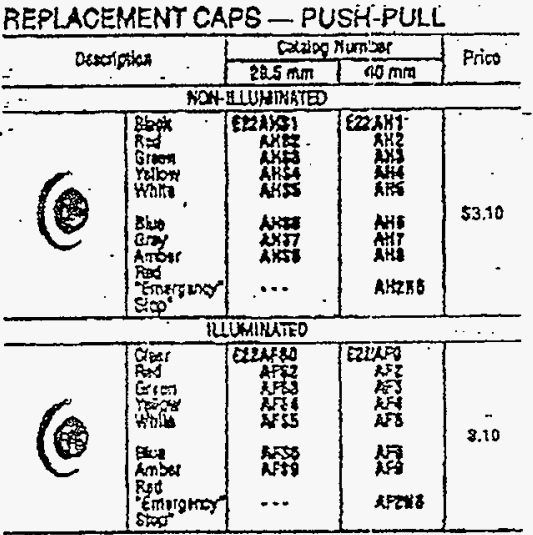

REPLACEMENT BELECTOR SWITCH

LEVERS \& KNOBS

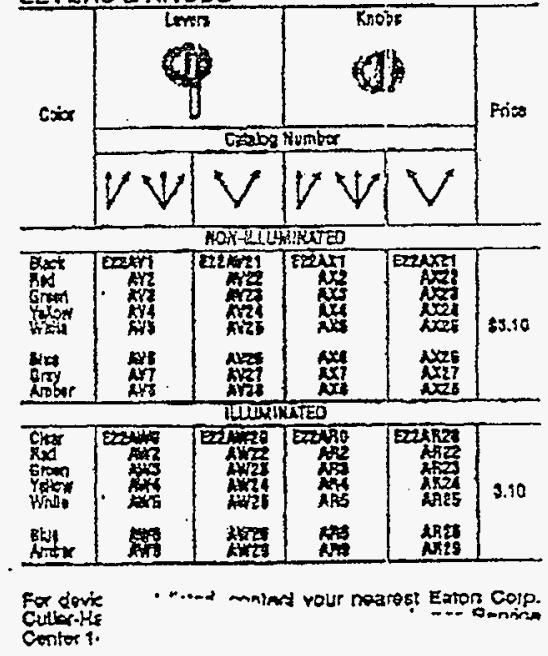

REPLACEMENT LENSES -

INDICATING LIGHTS

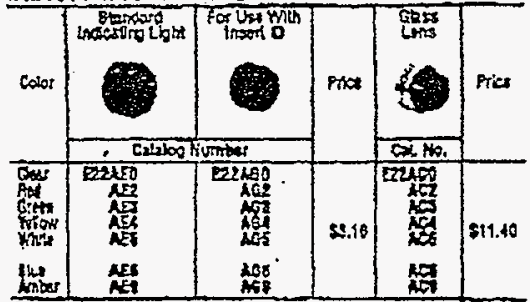

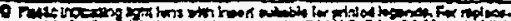

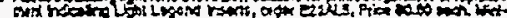

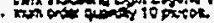

Conters.

QSCOUKT BCKEDUR TED-1

Trona

जाas

HNF-2488, Rev. 0

Page B-43

CALC.W320-31-015

ATTACHMENT: M..

$57 \cdot 3$ of 4 
CALC $W 320-31-015$

ATTACHMENT:M

SH. 4 of 4

62

CUTLERHÄHMER FREEDOM SKATES

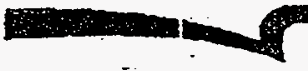

nowecerios:

AE1B, ANTB, AE58, ANES

CE15, ONIF, CN35, CE55 And CNES

AUXILIARY CONTACTS - I.E.C. SIZES A-K, NEMA SIZES OO-2

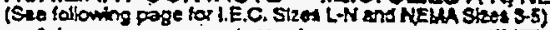

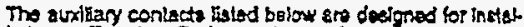
tatien on Froodom Sortwe eferters end conlactore. Snap-an design isciticles quick, essy thualiation.

Thass bllurealed obsigs contact bucka, faturng siver

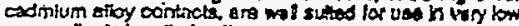
energy tragis leven ciratito.

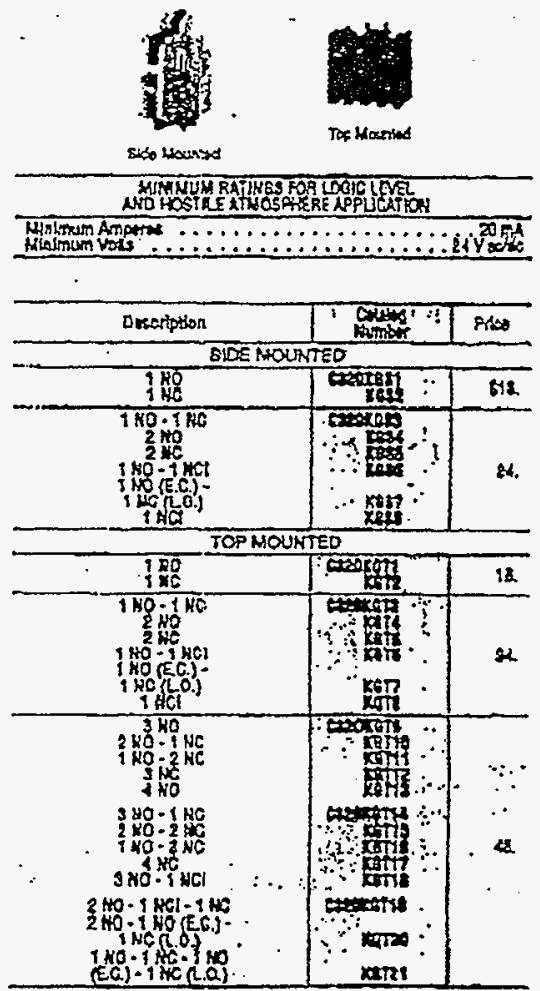

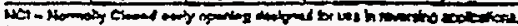

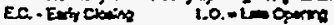

BITH

HNF-2488, Rev. 0 Page B-44
AUXIUARY CONTACT RATINGS -

ABOO (Amporab)

\begin{tabular}{|c|c|c|c|c|}
\hline \multirow{2}{*}{ Corrat: } & \multicolumn{4}{|c|}{ Tovols } \\
\hline & $180 Y$ & $240 \mathrm{~V}$ & $200 v$ & $800 \mathrm{~V}$ \\
\hline 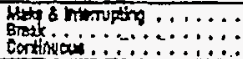 & $\begin{array}{l}60 \\
6 \\
50\end{array}$ & $\begin{array}{r}30 \\
-18 \\
-18\end{array}$ & 1.35 & 10 \\
\hline
\end{tabular}

AUXILIARY CONTACT APPLICATION

\begin{tabular}{|c|c|c|c|c|}
\hline \multirow{2}{*}{$\mathrm{Ha}$} & \multirow{2}{*}{86} & \multirow{2}{*}{ Pats } & \multicolumn{2}{|c|}{ 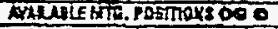 } \\
\hline & & & Oxinty: & NELA I Exetos i \\
\hline $\begin{array}{l}\text { A5t? } \\
\text { AEs: }\end{array}$ & 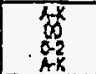 & 3 & 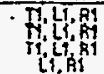 & $\left\{\begin{array}{l}-\infty \\
\{1, R\}\end{array}\right.$ \\
\hline Ext & $\begin{array}{l}0.2 \\
1-4 \\
0-1 \\
8-1\end{array}$ & 24 & 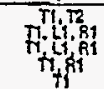 & - $\begin{array}{c}\ldots \\
\ldots \\
\ldots \\
\cdots\end{array}$ \\
\hline Crib & $\begin{array}{l}\infty \\
0-2 \\
1.2 \\
1.2\end{array}$ & $\begin{array}{l}\frac{24}{2-8} \\
5 \\
5\end{array}$ & 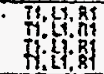 & ! \\
\hline ats & $\begin{array}{l}10 \text { Ampar } \\
20 \text { Anver } \\
\text { os Anpir }\end{array}$ & $\begin{array}{l}2-1 \\
2 \cdot 5 \\
5 \\
5\end{array}$ & 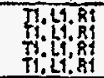 & $\begin{array}{l}\text { t1 } \\
\cdots \\
\cdots\end{array}$ \\
\hline Es: & $c^{x-3}$ & 8 & $\begin{array}{l}\text { L1. } \\
\text { ril } \\
\text { T }\end{array}$ & $\cdots$ \\
\hline
\end{tabular}

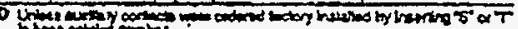

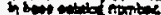

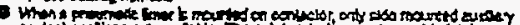

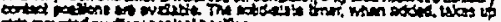

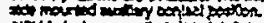

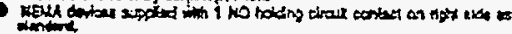
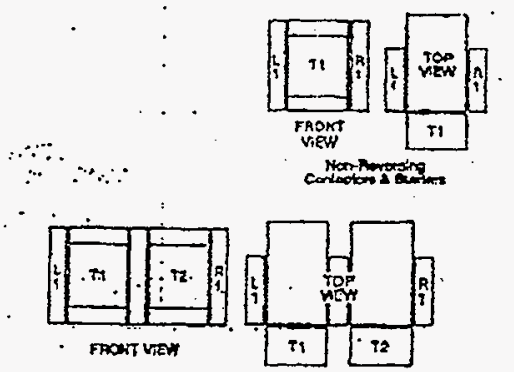

cortisintidation

: $\quad$ DISCOUAT SCKEOHE 100.: Nhenturi: 
HNF-2488, Rev. 0

W320-31-022

Control Circuit Sizing \& Voltage

Drop Analysis for Seismic

Shutdown System (Class IE)

C- i 


\section{Fluor Daniel Northwest}

This sheet shows the status and description of the attached Design Analysis sheets.
Discipline Electrical
wo/Job No. ER4319
Calculation No. W320-31-022

Project No. \& Nane W320, Tank 241-C-106 Sluicing

Calculation Item Control Circuit Sizing \& Voltage Drop Analysis for Sejsmic Shutdown System (Class. IE)

These calculations apply to:
Dwg. No. H-2-818679, Sheets 1 \& 2
Rev. No. 0
Dwg. No. H-2-818696, Sheets 1 \& 2
Rev. No. 0

other (Study, CDR) KGS-94-009 Project 93L-EW-329

Rev. No. NA

The status of these calcutations is:

[] Preliminary Calculations

[X] Final calculations

[] Check Calculations (On Calculation Dated)

[] Void Calculation (Reason Voided)

Incorporated in Final Drawings?

[X] Yes [] No

This calcutation verified by independent "check" calculations? [] Yes [X] No

Original and Revised Calcutation Approvals:

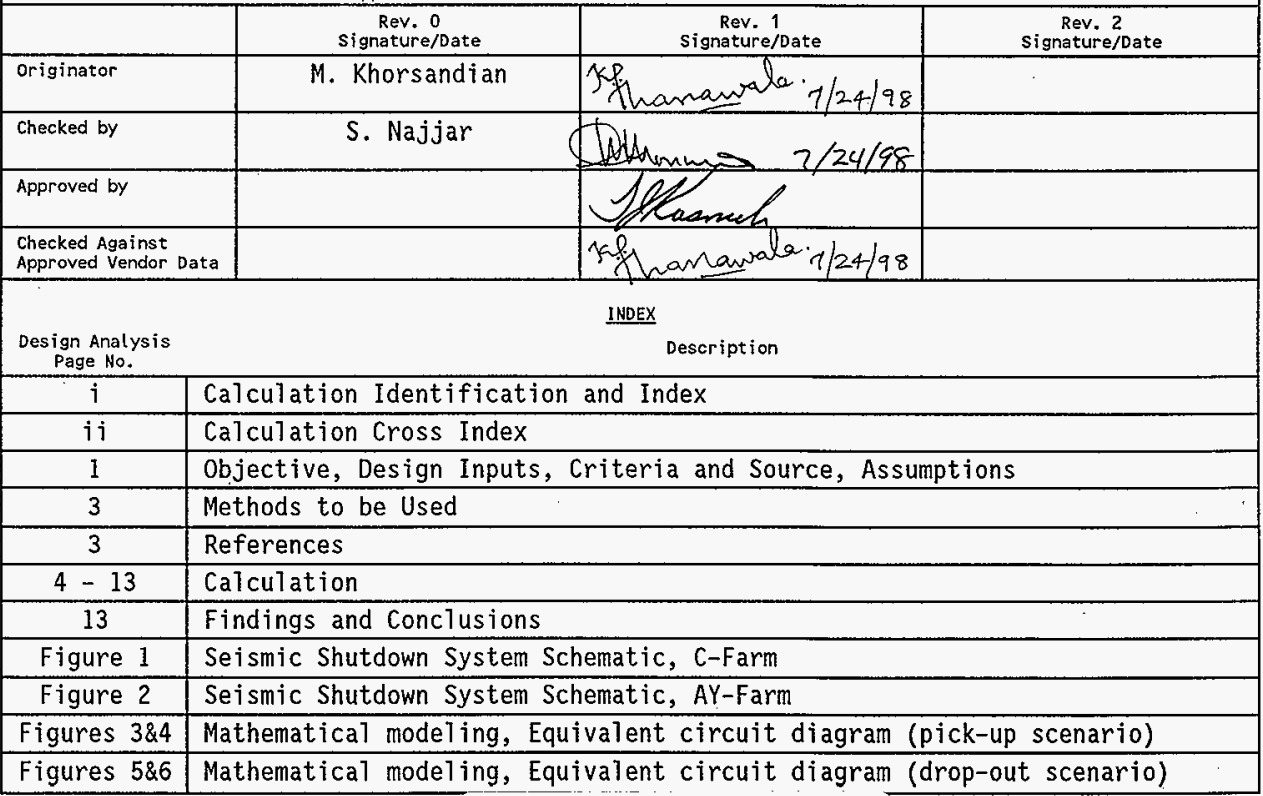




\begin{tabular}{|c|c|c|c|c|}
\hline \multirow{2}{*}{\multicolumn{2}{|c|}{ Fluor Daniel Northwest }} & \multirow{2}{*}{\multicolumn{2}{|c|}{$\begin{array}{l}\text { CALCULATION IDENTIFICATION AND } \\
\text { INDEX } \\
\text { cont inuation sheet }\end{array}$}} & Page $i j$ of 13 \\
\hline & & & & $04 / 17 / 95$ \\
\hline \multicolumn{2}{|c|}{ Discipline Electrica] } & lob & \multicolumn{2}{|c|}{ Calculation No. W320-31-022 } \\
\hline & \multicolumn{2}{|c|}{$\begin{array}{c}\text { Rev. } 0 \\
\text { Signature/Date } \\
\end{array}$} & $\begin{array}{c}\text { Rev. } 1 \\
\text { Signature/Date }\end{array}$ & $\begin{array}{c}\text { Rev. } 2 \\
\text { Signature/Date }\end{array}$ \\
\hline originator & \multicolumn{2}{|c|}{ M. Khorsandian } & & \\
\hline Checked by & \multicolumn{2}{|c|}{ S. Najjar } & & . \\
\hline
\end{tabular}

\begin{tabular}{|c|c|}
\hline $\begin{array}{l}\text { Design Analysis } \\
\text { Page No. }\end{array}$ & $\stackrel{\text { INDEX }}{\text { Description }}$ \\
\hline A-1 to $A-2$ & Attachment A: Westinghouse, Size 6, Type A201k6CX Catalog cut \\
\hline $\mathrm{B}-1$ to $\mathrm{B}-2$ & Attachment B: Westinghouse Type AR600 and GE CR120B Relay Information \\
\hline $\mathrm{C}-1$ & Attachment C: 750 VA, Control Power Transformer (CPT) Impedance Data \\
\hline D-1 to $D-3$ & Attachment D: Bussman FNQ Type Fuse Data \\
\hline$E-1$ to $E-5$ & Attachment E: Cutler-Hammer 1025T and GE CR104P Indicating Light Data \\
\hline$F-1$ to $F-6$ & $\begin{aligned} \text { Attachment F: Rockbestos Firewal1 SIS Switchboard Wire data including } \\
\text { ICEA S-68-5I6 Resistance and Okonite Temp. Correc. factors }\end{aligned}$ \\
\hline G-1 & Attachment G: Telephone conversation record with Kinemetrics, Inc. \\
\hline $\mathrm{H}-1$ & Attachment $H:$ Electronic $1 / 0$ board digital output information \\
\hline & \\
\hline & \\
\hline & \\
\hline & \\
\hline & \\
\hline & \\
\hline & 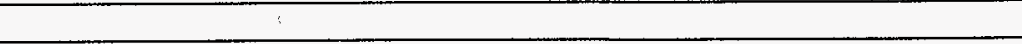 \\
\hline & \\
\hline & \\
\hline & \\
\hline & \\
\hline & \\
\hline & \\
\hline & \\
\hline & \\
\hline
\end{tabular}

HNF-2488, Rev. 0

Page C-2 


\section{Fluor Daniel Northwest}

DESIGN ANALYSIS
Calc. No. W320-31-022

Revision 1

Page No. 1 of 13

client WHC

subject Control Circuit Sizing \& Voltage Drop Analysis for Seismic

Shutdown System (Class 1E)

Location 200E; C \& AY Tank Farms

Wo/Job No. ER4319

$\begin{array}{lll}\text { Date } 4 / 17 / 95 & \text { By } & \text { M. Khorsandian } \\ \text { Checked } 4 / 17 / 95 & \text { By } & \text { S. Najjar } \\ \text { Revised } 7 / 24 / 98 & \text { By } & \text { KP Thanawala }\end{array}$

\section{$1.0 \quad$ OBJECTIVE}

The objective of this calculation is:

a. To determine the adequacy of voltage supplied by the electrical power distribution system to the contactor coil.

b. To size and select control loop cables supplying the contactor coil.

c. To size and select the cable connecting contactor control circuit to the "Emergency Trip" switch in control room.

d. To perform a voltage drop analysis of the control circuit and establish the minimum voltages allowed at the source terminal (secondary terminals of Transformer T1, or AY-PDP-1 distribution panel) in order to satisfy device pickup and holding voltages requirements. The calculated source voltage will be compared with the predicted steady-state and transient voltages in order to determine the adequacy of the circuits.

\section{$2.0 \quad$ DESIGN INPUTS}

a. KGS-94-009 Project 93L-EW-320, Tank 241-C-106 Sluicing, Letter of Instruction, Definitive Design, Rev. 6, April 1994.

\subsection{CRITERIA AND SOURCE}

a. WHC-SD-W320-FDC-001, Rev. 2; Functional Design Criteria for Tank 241-C-106 Waste Retrieval, Project W-320.

\subsection{ASSUMPTIONS}

a. The minimum Steady State voltage at source terminal is assumed to be $5 \%$ below its nominal voltage of $480 \mathrm{~V}$; i.e. $480 \times 0.95=456 \mathrm{~V}$.

b. The minimum transient voltage at source terminal is assumed to be $25 \%$ below its nominal voltage of $480 \mathrm{~V}$; i.e. $480 \times 0.75=360 \mathrm{~V}$. This value is typical for transient situations at power plants and power generators, and is based on industry experience.

c. The maximum Steady State voltage at source terminal is assumed to be $5 \%$ over its nominal voltage of $480 \mathrm{~V}$; i.e. $480 \times 1.05=504 \mathrm{~V}$. This value is typical at power plants and power generators. 


\section{Fluor Daniel Northwest}

DESIGN ANALYSIS
Calc. No, W320-31-022

Revision 1

Page No. 2 of 13

client WHC

wo/Job No. ER4319

subject Control Circuit Sizing \& Voltage

Drop Analysis for Seismic

Shutdown system (Class 1E)

Location 200E; C \& AY Tank Farms

checked $4 / 17 / 95$ By $S$. Najjar

Revised $7 / 24 / 98$ By KP Thanawala

d. Loop conductors are considered to be \#14 AWG unless otherwise noted in this calculation or on the drawing.

e. Resistance for loop conductors is based on $55^{\circ} \mathrm{C}$. This value is the maximum anticipated ambient temperature, and is based on the consideration that these conductors are low current carrying conductors.

f. Cable reactance is assumed equal to zero since the resistive component of impedance is much larger than the reactive component of impedance for cable sizes utilized in this control loop.

g. Resistance of the cable connecting upstream transformer (transformer T1), or distribution panel (AYPDP-1) to the contactor assembly is negligible due to insignificant length.

h. Percent impedance of a 750 VA Control Power Transformer is not published by the manufacturer. The $\% \mathrm{Z}=4.44$ of a similar dry-type distribution transformer is used in this calculation. This value is typical for $750 \mathrm{VA}$ transformers.

i. Indicating lights are transformer type, and have very high input impedance. Indicating lights impedances are assumed to be purely resistive.

j. The impedance of fuses larger than 3 amps is neglected.

k. Minimum pick up and hold in voltages of Westinghouse AR industrial relay is not published by the manufacturer. Therefore, it is conservatively assumed that relay minimum pick up and hold in voltages to be $\% 85$ of its nominal coil voltage, i.e.:

$\begin{aligned} \mathrm{V}_{\min \text { pics up }} \quad=\mathrm{V}_{\min \text { holl in }} & =120 \times 85 \% \\ & =102 \mathrm{~V}\end{aligned}$

1. The most restrictive circuit device is the device being analyzed for pick-up and hold-in capabilities.

m. The impedance of panel wiring is assumed to be zero due to insignificant conductor lengths.

n. The impedance of circuit loads/devices is based on rated voltage and current.

o. The design data for Lamp No. 755 for Cutler-Hammer 10250T indicating lights is not provided by the vendor. Therefore, the data provided for the same lamp for GE CR104P indicating lights is used.

p. The Hold-in Wattage data for Westinghouse AR600 relay coils is not provided by the vendor. Therefore, the data provided for GE CR120B relay coil, which is similar, is used. 


\section{Fluor Daniel Northwest}

DESIGN ANALYSIS
Calc. No. W320-31-022

Revision 1

Page No. 3 of 13 client WHC

subject Control Circuit Sizing \& Voltage

Drop Analysis for Seismic

Shutdown system (Class 1E)
Wo/Job No. ER4319

Date $4 / 17 / 95$ By $M$. Khorsandian

Checked $4 / 17 / 95$ By $S$. Najjar

Revised $7 / 24 / 98$ By KP Thanawala

1. For each utilization device, the minimum required terminal voltage for adequate operation of the device is obtained. For contactor coil and relays this will typically include a minimum pick-up voltage and a minimum hold-in voltage.

2. For each utilization device, the maximum power required by the device is obtained. For contactor coil and relays, this will normally include a momentary in-rush (pick-up) current and a steady state (hold-in) current.

3. Using transformer \% $\mathrm{R}$ and \%X, Control Power Transformer (CPT) impedance is calculated.

4. Using cable sizes and lengths, conductor impedances are calculated.

5. Impedance of each utilization device according to whether the device is drawing in-rush current or holdin current is calculated.

6. From the control circuit diagram, the device alignment that yields the heaviest load on the CPT is determined. Based on this alignment the most restrictive device in the control circuit is determined. Due to large inrush and hold-in current, typically, contactor coil is among the most restrictive devices in the circuit.

7. A mathematical model using the values determined in previous steps is constructed, showing the worst case loop loading, the most restrictive device and minimum pick-up and drop-out voltages across this most restrictive device.

8. Using electrical circuit theory, the minimum pick-up and drop-out voltages required across the source terminal is calculated.

9. The required minimum pick-up and drop-out voltage values across source terminal will be compared with the minimum steady state and minimum transient voltage values to determine the adequacy of the control circuit.

\subsection{REFERENCES}

1. Westinghouse Catalog 25-000, 1993

2. Cutler-Hanomer Quick Selector Catalog 25-000, 1995

3. Okonite Company Catalog, "Power, Control and instrumentation Cables", 1990. 


\section{Fluor Daniel Northwest}

\section{DESIGN ANAIYSIS}

Catc. No. W320-31-022

Revision 1

Page No. 4 of 13 client WHC

subject Control Circuit Sizing \& Voltage Drop Analysis for Seismic Shutdown System (Class 1E)

Location 200E; C \& AY Tank Farms
WO/Job Ho. ER4319

Date $4 / 17 / 95$ вy M. Khorsandian

Checked $4 / 17 / 95$ By $S$. Najjar

Revised $7 / 24 / 98$ By. KP Thanawala

4. Bussmann Fuse Catalog, Section 3

5. NFPA-70, National Electrical Code, 1993

6. Westinghouse Consulting Application Guide, 1991; Dry-Type Distribution Transformers technical Data

7. GE Electrical Distribution \& Control Catalog, 1993

8. Ref. Standard ICEA S-68-516, WC 8-1988

\subsection{CALCULATION}

Seismic Shutdown System (SSS) is consisted of 2 sets of redundant contactor assemblies (Figures 1 and 2). Since all 4 contactors are identical, only one unit, seismic shutdown system \#1, Figure \#1 is analyzed.

\subsection{CIRCUIT DATA}

7.1.1 Westinghouse, size 6, 3 phase, $480 \mathrm{~V}$ contactor, Catalog \# A201K6CA (Coil M1)

Coil data (Attachment A):

$\begin{array}{ll}\text { In-Rush VA } & =2900 \mathrm{VA} \\ \text { Hold-In VA } & =220 \mathrm{VA} \\ \text { Hold-In Watts } & =42 \mathrm{~W} \\ \text { In-Rush } \mathrm{P}_{\mathrm{f}} & =0.0145 \\ \text { Hold-In } \mathrm{P}_{\mathrm{f}} & =0.19 \\ \text { Voltage Rating } & =120 \mathrm{VAC} \\ \text { Min. Pick-Up Voltage } & =84 \mathrm{~V} \\ \text { Min. Hold-In Voltage } & =72 \text { to } 84 \mathrm{~V}\end{array}$

7.1.2 Westinghouse AR 600 Relay (Relay coils JXY1361, JXY1362, JXY0621, JXY0622, YY13650, YY13651, YY13652, YY13653, YY06210, YY06211, YY06212 and YY06213) coil data (Attachment B):

$\begin{array}{lll}\text { In-Rush VA } & =96 \quad \text { VA } \\ \text { Hold-In VA } & =14 \quad \text { VA } \\ \text { Hold-In Watts } & =7 \quad \text { W } \\ \text { In-Rush } \mathrm{P}_{\mathrm{f}} & =0.0729 \\ \text { Hold-In } \mathrm{P}_{\mathrm{I}} & =0.5 \\ \text { Voltage Rating } & =120 \mathrm{VAC} \\ \text { Min. Pick-Up Voltage } & =102 \mathrm{~V} \\ \text { Min. Hold-In Voltage } & =102 \mathrm{~V}\end{array}$


Fluor Daniel Northwest

DESIGN ANALYSIS
Calc. No. W320-31-022

Revision 1

Page No. 5 of 13 client WHC

subject Control Circuit Sizing \& Voltage.

Drop Analysis for Seismic

Shutdown system (Class 1E)

Location 200E; C \& AY Tank Farms
HO/Job No. ER4319

Date $4 / 17 / 95$ By $M$. Khorsandian

checked $4 / 17 / 95$ вy $S$. Najjar

Revised $7 / 24 / 98$ By KP Thanawala

7.1.3 Control Power Transformer (CPT)

A 750 VA CPT is selected

$480 / 120 \mathrm{~V}$, Single phase
$\% \mathrm{Z}=4.44$
(Attachment C)

\subsubsection{Fuse Data}

"NUTHERM" has provided a 10 Amp control fuse for secondary side of transformer, and a 5 Amp fuse for isolation.

Since both these kinds of fuses are over 3 Amp the resistance is neglected.

$\mathrm{R}_{\mathrm{FNQ}-10}=0 \Omega$

$\mathrm{R}_{\mathrm{PNQ}-\mathrm{S}}=0 \Omega$

7.1.5 Indicating Lights

Indicating lights provided are Cutler-Hammer $10250 \mathrm{~T}$ transformer type (Attachment E).

Cutler-Hammer $10250 \mathrm{~T}$ transformer secondary voltage $=6 \mathrm{~V}$

Lamp No. 755

\subsubsection{Seismic Switch Power Supply}

Power supply unit rating is $120 \mathrm{VAC}, 150 \mathrm{~mA}$ (Attachment $\mathrm{G}$ ). For conservatism, it is assumed power supply has an input rating of $300 \mathrm{~mA}$.

\subsubsection{Cable Data}

\#14 AWG size is provided for loop conductors

$$
\begin{aligned}
& R_{\# 14 \text { AWG } 125^{\circ} \mathrm{C}}=2.79 \Omega \text { Per } 1000 \mathrm{ft} \quad \text { (Attachment F) }
\end{aligned}
$$

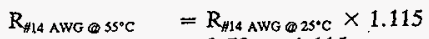

$$
\begin{aligned}
& =2.79 \times 1.115
\end{aligned}
$$

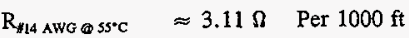


Fluor Daniel Northwest

DESIGN ANAIYSIS
Calc. No. W320-31-022

Revision 1

Page No. 6 of 13 client WHC

subject Control Circuit Sizing \& Voltage

Drop Analysis for Seismic

Shutdown System (Class 1E)

Location 200E; C \& AY Tank Farms
wo/Job No. ER4319

Date $4 / 17 / 95$ вy $M$. Khorsandian

checked $4 / 17 / 95$ By $S$. Najjar

Revised $7 / 24 / 98$ By KP Thanawala

\# 12 AWG size is selected for cable from SSS cabinet to emergency stop switch in control trailer

$\mathrm{R}_{\# 12 \text { AWG } @ 25^{\circ} \mathrm{C}}=1.75 \Omega$ Per $1000 \mathrm{ft} \quad($ Attachment $\mathrm{F})$

$\mathrm{R}_{* 12 \mathrm{AWG} \otimes 55^{\circ} \mathrm{C}}=\mathrm{R}_{\# 12 \mathrm{AWG} \otimes 25^{\circ} \mathrm{C}} \times 1.115$

$=1.75 \times 1.115$

$R_{\text {H12 AWG } \otimes s^{\circ} \mathrm{C}} \approx 1.95 \Omega$ Per $1000 \mathrm{ft}$

\section{$7.2 \quad$ ANALYSIS}

7.2.1 Cable:

Cable A: From SSS cabinet to emergency stop switch at control trailer, approximately $100 \mathrm{ft}$ of $\# 12$ AWG;

$\mathrm{R}_{\text {Cable A }} \quad=100 \times 2 \times(1.95 \div 1000)$

$$
=0.39 \Omega
$$

Cable B: Seismic Switch power supply power cord, approximately $5 \mathrm{ft}$ of \#14 AWG;

$\mathrm{R}_{\text {Cable } \mathrm{B}} \quad=5 \times 2 \times(3.11 \div 1000)$

$=0.031 \Omega$

Cable C: From "SET" (Start) switch to seismic switch relay contacts, approximately $5 \mathrm{ft}$ of \#14 AWG;

$\mathrm{R}_{\text {Cable }} \mathrm{C} \quad=5 \times 2 \times(3.11 \div 1000)$

$=0.031 \Omega$

Cable D: From Seismic Switch relay contacts to temperature switch contacts, approximately $5 \mathrm{ft}$ of \#14 AWG;

$\mathrm{R}_{\mathrm{Csble}} \mathrm{D} \quad=5 \times 2 \times(3.11 \div 1000)$

$$
=0.031 \Omega
$$

Cable E: From temperature switch contacts to contactor coil terminals, approximately $5 \mathrm{ft}$ of \#14 AWG;

$\mathrm{R}_{\text {Cable } \mathrm{E}} \quad=5 \times 2 \times(3.11 \div 1000)$

$$
=0.031 \Omega
$$




\section{Fluor Daniel Northwest}

DESIGN ANALYSIS
Calc. No. W320-31-022

Revision 1

Page No. 7 of 13

WO/Job No. ER4319

Date $4 / 17 / 95$ вy $M$. Khorsandian

Checked $4 / 17 / 95$ вy $S$. Najjar

Revised $7 / 24 / 98$ By KP Thanawala

\subsubsection{Transformer:}

Per unit impedance of Control Power Transformer is:

$\% Z_{\mathrm{T}} \quad=4.44 \quad$ (Attachment $\mathrm{C} \&$ Section 4.0-8)

Conservatively assuming $X=R$

$$
\begin{array}{ll}
\mathrm{Z}^{2}=\mathrm{X}^{2}+\mathrm{R}^{2} & \Rightarrow \quad \mathrm{R} \approx 3.14 \Omega, \mathrm{X} \approx 3.14 \Omega \\
\mathrm{Z}_{\mathrm{Tpu}} & =0.0314+\mathrm{j} 0.0314
\end{array}
$$

\subsubsection{Indicating Lights:}

Indicating Lights YL13650B \& YL13651B (YL13652B, YL13653B, YL06210B, YL06211B, YL06212B, YL06213B) are transformer type with the bulb rating of:

Lamp No. 755; Design Volt $=14 \mathrm{~V}, \quad$ Design Amps $=0.15 \mathrm{~A} \quad$ (Attachment E)

$$
\begin{aligned}
\mathrm{R}_{\mathrm{lamp}} & =14 \div 0.15 \\
& \approx 93 \Omega
\end{aligned}
$$

The current on the secondary side of indicating light transformer is:

$$
\begin{aligned}
I_{\text {secondsay }} & =6 \div 93 \\
& =0.0645 \mathrm{~A}
\end{aligned}
$$

The current on the primary side of indicating light transformer can be determined as follows:

$$
\begin{aligned}
I_{\text {primasy }} & =0.0645 \times[6 \div 120] \\
& =0.0032 \mathrm{~A}
\end{aligned}
$$

Assuming the transformer has an efficiency rating of $50 \%$, then:

$$
I_{\text {primary }}=0.0064 \mathrm{~A}
$$

Therefore, the total resistive value of the indicating lights (IL) seen by the control circuit can be determined as follows:

$$
\begin{aligned}
\mathrm{R}_{\mathrm{IL}} & =120 \div 0.0064 \\
& =18.75 \mathrm{~K} \Omega
\end{aligned}
$$




\section{Fluor Daniel Northwest}

\section{DESIGN ANALYSIS}

Client WHC

subject Control Circuit Sizing \& Voltage

Drop Analysis for Seismic

Shutdown system (Class $1 E$ )

Location 200E; C \& AY Tank Farms
Calc. No. W320-31-022

Revision 1

Page No. 8 of 13

WO/Job No. ER4319

Date $4 / 17 / 95$ By M. Khorsandian

checked $4 / 17 / 95$ вy $S$. Najjar

Revised $7 / 24 / 98$ By KP Thanawala

\subsubsection{Pick-Up (In-Rush) scenario:}

From the acquired data and referring to Figure 1 (Figure 2), the contactor coil is the most restrictive load since it has the largest in-rush current, and the longest cable loop . Loop loading for the pick-up circuit is based on the following:

a. Relay coil YY13650 (YY13652, YY06211 \& YY06213) for remote "TRIP" indication is energized and it is drawing hold-in current.

b. Relay coil YY13651 (YY13653, YY06210 \& YY06212) for remote "SET" indication is omitted since it would not be energized until contactor coil is energized.

c. Seismic Switch Power Supply (SSPS) is considered to be drawing hold-in current since it is in parallel with the contactor coil and does not pull current through the contactor loop. SSPS is always energized as long as control circuit is energized.

d. Relay coil JXY1361 (JXY1362, JXY0621 \& JXY0622) for power failure indication is considered to be drawing hold in current since it is in parallel with contactor coil. This coil is always energized as long as control circuit is energized.

e. Relay coil AY1361A (AY1362A, AY0621A \& AY0622A) is a 24 VDC battery powered, and it is considered to be internal to SSPS, therefore, it is not considered in pick-up scenario.

f. The current drawn by the indicating light units can be neglected since they are in parallel with the contactor coil, and their resistances are very high. There will be one indicating light lit at a given scenario.

7.2.4.1

Based on Step 7.2.4 scenario, the impedances of various devices are calculated:

$P_{\underline{1}}=\operatorname{Cos} \phi$

Z

$=\left[V^{2} \div V A\right] \times\left[\operatorname{Cos} \phi+j \operatorname{Sin}\left(\operatorname{Cos}^{-1} P_{t}\right)\right]$

$\mathrm{Z}_{\mathrm{MIR}}$

$\left.=\left[(120)^{2} \div 2900\right)\right] \times\left[0.0145+\mathrm{j} \operatorname{Sin}\left(\operatorname{Cos}^{-1} 0.0145\right)\right]$

$\approx 0.072+\mathrm{j} 4.96 \Omega$

$\mathrm{Z}_{\mathrm{ssps}} \quad=115 \div 0.3$

$\approx 380 \Omega$

$\mathrm{Z}_{\mathrm{JXY} 1361 \mathrm{HI}}$

$\left.=\left[(120)^{2} \div 14\right)\right] \times\left[0.5+j \operatorname{Sin}\left(\operatorname{Cos}^{-1} 0.5\right)\right]$

$=514.28+\mathrm{j} 890.77 \Omega$

$\mathrm{Z}_{\mathrm{YY13650 \textrm {HI }}}$

$=514.28+\mathrm{j} 890.77 \mathrm{\Omega}$ 
Fluor Daniel Northwest

DESIGN ANALYSIS

client WHC

Subject Control Circuit Sizing \& Voltage

Drop Analysis for Seismic

Shutdown System (Class 1E)

Location 200E; C \& AY Tank Farms
Calc. No. W320-31-022

Revision 1

Page No. 9 of 13

Wo/Job No. ER4319

Date $4 / 17 / 95$ By M. Khorsandian

checked $4 / 17 / 95$ ву $S$. Najjar

Revised $7 / 24 / 98$ By KP Thanawala

7.2.4.2 A mathematical model is constructed as shown on figure 3. Indicating lights are in parallel with contactor coil. Due to high impedances of indicating lights, the impedances contributed by these lights are omitted from the model.

The equivalent circuit is further reduced (Figure 4) using electrical circuit theory as follows:

$$
\begin{aligned}
& \mathrm{I}_{\mathrm{M}} \quad=\mathrm{V}_{\mathrm{M}} \div \mathrm{Z}_{\mathrm{M}} \\
& =84 \div(0.072+\mathrm{j} 4.96) \\
& =0.245-\mathrm{j} 16.93 \mathrm{~A} \\
& \mathrm{Z}_{3}=\mathrm{R}_{\mathrm{IF} 1}+\mathrm{R}_{\mathrm{IF2}}+\mathrm{R}_{\text {Cable A }}+\mathrm{R}_{\mathrm{IF} 3}+\mathrm{R}_{\mathrm{IFA}}+\mathrm{R}_{\text {Cable C }}+\mathrm{R}_{\text {Cable D }}+\mathrm{R}_{\text {Cable E }} \\
& =2 \times 0+0.39+2 \times 0+0.031+0.031+0.031 \\
& \approx 0.483 \Omega \\
& \mathrm{V}_{2}=\mathrm{I}_{\mathrm{M}} \times\left(\mathrm{Z}_{3}+\mathrm{Z}_{\mathrm{M}}\right) \\
& =(0.245-\mathrm{j} \mathrm{16.93}) \times(0.483+0.072+\mathrm{j} 4.96) \\
& =84.11-\mathrm{j} 8.18 \mathrm{~V} \\
& \mathrm{Z}_{2} \quad=\mathrm{Z}_{\text {ssps }}+\mathrm{R}_{\text {Cable } \mathrm{B}} \\
& =380+0.031 \\
& \approx 380 \Omega \\
& Z_{1} \quad=Z_{2}\left\|Z_{\mathrm{JXY} 1361}\right\| Z_{\mathrm{YY} 13650} \\
& =[380 \times(514.28+\mathrm{j} 890.77)] \div[(514.28+\mathrm{j} 890.77)+2 \times 380] \\
& \approx 227.76+\mathrm{j} 106.42 \Omega \\
& \mathrm{I}_{\mathrm{Z} 1} \quad=\mathrm{V}_{2} \div \mathrm{Z}_{1} \\
& =(84.11-\mathrm{j} 8.18) \div(228.58+\mathrm{j} 111.03) \\
& =0.2893-\mathrm{j} 0.1711 \mathrm{~A} \\
& \mathrm{I}_{\mathrm{TOT}} \quad=\mathrm{I}_{\mathrm{Zl}}+\mathrm{I}_{\mathrm{M}} \\
& =0.5343-\mathrm{j} 17.1 \mathrm{~A} \\
& \mathrm{~V}_{1} \quad=\mathrm{V}_{2}+\mathrm{I}_{\mathrm{TOT}} \times \mathrm{R}_{\mathrm{Fu}} \\
& =84.11-\mathrm{j} 8.18+(0.5343-\mathrm{j} 17.1) \times 0 \\
& =84.11-j 8.18 \mathrm{~V} \\
& \mathrm{I}_{\text {TOT pu }}=[(0.5343-\mathrm{j} 17.1) \times(120)] \div 750 \\
& =0.0855-\mathrm{j} 2.74
\end{aligned}
$$


Fluor Daniel Northwest

DESIGN ANALYSIS
Calc. No. W320-31-022

Revision 1

Page No. 10 of 13 client WHC

subject Control Circuit Sizing \& Voltage

Drop Analysis for Seismic Shutdown System (Class IE)

Location 200E; C \& AY Tank Farms
wo/Job No. ER4319

Date $4 / 17 / 95$ вy M. Khorsandian

Checked $4 / 17 / 95$ By S. Najjar

Revised $7 / 24 / 98$ By KP Thanawala

$$
\begin{aligned}
\mathrm{V}_{1 \mathbf{p u}} & =(84.11-\mathrm{j} 8.18) \div 120 \\
& =0.7-\mathrm{j} 0.068 \\
\mathrm{~V}_{\mathrm{MIN}} & =\left[\mathrm{I}_{\mathrm{TOT}} \times \mathrm{Z}_{\mathrm{T} \mathrm{pu}}+\mathrm{V}_{1 \mathrm{pu}}\right] \times 480 \\
& =[(0.0855-\mathrm{j} 2.74) \times(0.0314+\mathrm{j} 0.068)+0.7-\mathrm{j} 0.34] \times 480 \\
& =[0.7887-\mathrm{j} 0.1514] \times 480 \\
& =378.6-\mathrm{j} 72.6 \\
& =385.5 \angle-11^{\circ} \mathrm{V} \\
& \therefore \quad\left|\mathrm{V}_{\text {MN picksup }}\right|=385.5 \mathrm{~V}
\end{aligned}
$$

This value represents the minimum source voltage required to ensure that all devices can pick up.

Since $V_{\text {MIN pickup }}<V_{\text {LMIT picksup }}\left(V_{\text {LIMTT pickup }}\right.$ assumed to be $456 \mathrm{~V}$ in Section $\left.4.0-1\right)$, the control loop is adequate. The most restrictive device, contactor coil, can pick up when the minimum source voltage, 456 $\mathrm{V}$, is present at the secondary side of transformer $\mathrm{T} 1$.

\subsubsection{Drop-Out (Hold-1N) Scenatio:}

From the acquired data and referring to Figure 1 (Figure 2), the contactor coil is again the most restrictive load since it has the largest hold-in current, and the longest cable loop. Loop loading for the drop-out circuit is based on the following:

a. Relay coil YY13651 (YY13653, YY06210 \& YY06212) for remote "SET" indication is energized and it is drawing hold-in current.

b. Relay coil YY13650 (YY13652, YY06211 \& YY06213) for remote "TRIP" indication is omitted since it would not be energized until contactor coil is de-energized.

c. Seismic Switch Power Supply (SSPS) is considered to be drawing hold-in current since it is in parallel with the contactor coil and does not pull current through the contactor loop. SSPS is always energized as long as control circuit is energized.

d. Relay coil JXY1361 (JXY1362, JXY0621 \& JXY0622) for power failure indication is considered to be drawing hold in current since it is in parallel with contactor coil. This coil is always energized as long as control circuit is energized.

e. Relay coil AY1361A (AY1362A, AY0621A \& AY0622A) is a 24 VDC battery powered, and it is considered to be internal to SSPS, therefore, it is not considered in drop-out scenario. 


\section{Fluor Daniel Northwest}

\section{DESIGN ANAIYSIS}

Client WHC

subject Control Circuit Sizing \& Voltage

Drop Analysis for Seismic

Shutdown System (Class IE)

Location 200E; C \& AY Tank Farms
Calc. No. W320-31-022

Revision 1

Page No. 11 of 13

Ho/Job No. ER4319

Date $4 / 17 / 95$ By M. Khorsandian

checked $4 / 17 / 95$ By $S$. Najjar

Revised $7 / 24 / 98$ By KP Thanawala

7.2.5.1 Based on Step 7.2.5 scenario, impedances of various devices are calculated:

$$
\begin{aligned}
\mathrm{Z}_{\mathrm{M} \mathrm{HI}} & \left.=\left[(120)^{2} \div 220\right)\right] \times\left[0.19+\mathrm{j} \operatorname{Sin}\left(\operatorname{Cos}^{-1} 0.19\right)\right] \\
& \approx 12.44+\mathrm{j} 64.26 \Omega \\
\mathrm{Z}_{\text {ssps }} & =115 \div 0.3 \\
& \approx 380 \Omega
\end{aligned}
$$

7.2.5.2 A mathematical model is again constructed as shown on figure 5. Indicating lights are in parallel with contactor coil. Due to high impedances of indicating lights, the impedances contributed by these lights are omitted from the model.

The equivalent circuit is further reduced (Figure 6) using electrical circuit theory as follows:

$$
\begin{aligned}
\mathrm{I}_{\mathrm{M}} & =\mathrm{V}_{\mathrm{M}} \div \mathrm{Z}_{\mathrm{M}} \\
& =84 \div(12.44+\mathrm{j} 64.26) \\
& =0.24-\mathrm{j} 1.26 \mathrm{~A} \\
\mathrm{Z}_{3} \quad & =0.483 \Omega \\
\mathrm{V}_{2} \quad & =\mathrm{I}_{\mathrm{M}} \times\left(\mathrm{Z}_{3}+\mathrm{Z}_{\mathrm{M}}\right) \\
& =(0.24-\mathrm{j} 1.26) \times(0.483+12.44+\mathrm{j} 64.26) \\
& =84.07-\mathrm{j} 0.86 \mathrm{~V} \\
\mathrm{Z}_{2} \quad & =380 \Omega \\
\mathrm{Z}_{1} \quad & =\mathrm{Z}_{2}\left\|\mathrm{Z}_{\mathrm{JXY1351}}\right\| \mathrm{Z}_{\mathrm{YY} 13651} \\
& \approx 227.76+\mathrm{j} 106.42 \Omega \\
\mathrm{I}_{\mathrm{Z} 1} \quad & =V_{2} \div \mathrm{Z}_{1} \\
& =(84.07-\mathrm{j} 0.86) \div(227.76+\mathrm{j} 106.42) \\
& \approx 0.3015-\mathrm{j} 0.1447 \mathrm{~A}
\end{aligned}
$$




\section{Fluor Daniel Northwest}

\section{DESIGN ANALYSIS}

ctient WHC

subject Control Circuit Sizing \& Voltage

Drop Analysis for Seismic

Shutdown System (Class 1E)

Location 200E; C \& AY Tank Farms
Calc. No. W320-31-022

Revision 1

Page No. 12 of 13

Date $4 / 17 / 95$ By M. Khorsandian

checked $4 / 17 / 95$ By $S$. Najjar

Revised $7 / 24 / 98$ By KP Thanawala

$$
\begin{aligned}
& \mathrm{I}_{\mathrm{TOT}} \quad=\mathrm{I}_{\mathrm{Z} 1}+\mathrm{I}_{\mathrm{M}} \\
& =0.5415-\mathrm{j} 1.4047 \mathrm{~A} \\
& \mathrm{~V}_{1}=\mathrm{V}_{2}+\mathrm{I}_{\mathrm{TOT}} \times \mathrm{R}_{\mathrm{FU} 3} \\
& =84.07-\mathrm{j} 0.86+(0.5415-\mathrm{j} 1.4047) \times 0 \\
& =84.07-\mathrm{j} 0.86 \mathrm{~V} \\
& \mathrm{I}_{\text {Tor } \mathrm{pu}}=[(0.5415-\mathrm{j} 1.4047) \times(120)] \div 750 \\
& =0.0866-\mathrm{j} 0.225 \\
& \mathrm{~V}_{1 \text { pu }}=(84.07-\mathrm{j} 0.86) \div 120 \\
& =0.7-\mathrm{j} 0.007 \\
& V_{\text {MIN }}=\left[I_{\text {Tor pu }} \times Z_{\mathrm{Tpu}_{\mathrm{pu}}}+\mathrm{V}_{1 \mathrm{pu}}\right] \times 480 \\
& =[(0.086-\mathrm{j} 0.225) \times(0.0314+\mathrm{j} 0.0314)+0.7-\mathrm{j} 0.007] \times 480 \\
& =[0.71-\mathrm{j} 0.011] \times 480 \\
& =340.7-\mathrm{j} 5.5 \\
& =340.7 \angle-0.9^{\circ} \mathrm{V} \\
& \therefore \quad\left|\mathrm{V}_{\text {MIN dropout }}\right|=340.7 \mathrm{~V}
\end{aligned}
$$

This value represents the minimum source voltage transient dip to ensure that all devices will not drop-out under bus voltage transient situation.

Since $V_{M N \text { drop-out }}<V_{\text {LIMIT drop-out }}\left(V_{\text {LMMTr drop-oul }}\right.$ assumed to be $360 \mathrm{~V}$ in Section 4.0-2), the control loop is adequate. The most restrictive device, contactor coil, will not drop-out when the source voltage dips into minimum $360 \mathrm{~V}$ transient, at the secondary side of transformer $\mathrm{T} 1$.

\subsection{OVERVOLTAGE CONSIDERATION}

When maximum steady state voltage of 504 is present at the primary side of CPT, the voltage at the secondary side is conservatively calculated as follows:

$$
\begin{aligned}
\mathrm{V}_{\text {max secoocary }} & =120 \times[504 \div 480] \\
& =126 \mathrm{~V}
\end{aligned}
$$

Assuming no voltage losses in contactor coil loop, the contactor coil is subjected to $126 \mathrm{~V}$ which is less than the maximum allowable voltage of $132 \mathrm{~V}$ (Attachment A), i.e.:

$$
\begin{aligned}
\mathrm{V}_{\max \text { allowable }} & =120 \times 110 \% \\
& =132 \mathrm{~V}
\end{aligned}
$$


Fluor Daniel Northwest

DESIGN ANALYSIS calc. No. W320-31-022

Revision 1

Page No. 13 of 13 client WHC

subject Control Circuit sizing \& Voltage

Drop Analysis for Seismic

Shutdown system (Class 1E)

Location 200E; C \& AY Tank Farms
Wo/Job No. ER4319

Date $4 / 17 / 95$ вy M. Khorsandian

checked $4 / 17 / 95$ By $S$. Najjar

Revised $7 / 24 / 98$ By KP Thanawala

$$
\mathrm{V}_{\max \text { secondary }}=126 \mathrm{~V}<\mathrm{V}_{\max \text { allowable }}=132 \mathrm{~V}
$$

Therefore, contactor coil can safely operate under CPT primary voltage value of $504 \mathrm{~V}$ without injury to the operating coil.

\subsection{FINDINGS AND CONCLUSIONS}

1. The voltage supplied by the electrical power distribution system to the contactor coil is adequate.

2. \#14 AWG cable is adequate for internal wiring of contactor assembly, and cables supplying seismic switch power supply.

3. \#12 AWG cable to emergency stop switch in control room is adequate in size.

4. The voltage drop analysis of the control circuit shows that the minimum voltages allowed at the source for steady-state and transient conditions are adequate to satisfy the device pickup and holding voltage requirements.

This calculation shows that the control circuit of the size 6 contactor used in the Seismic Shutdown System is adequately sized. The contactor will pick up when worst case minimum bus voltage condition is present, and it will hold in during worst case minimum transient voltage situation. Nuisance tripping will not occur due to bus voltage normal fluctuations. Long lead cables and panel internal wiring sizes are adequately selected such that voltage drop will not adversely affect system operation. 


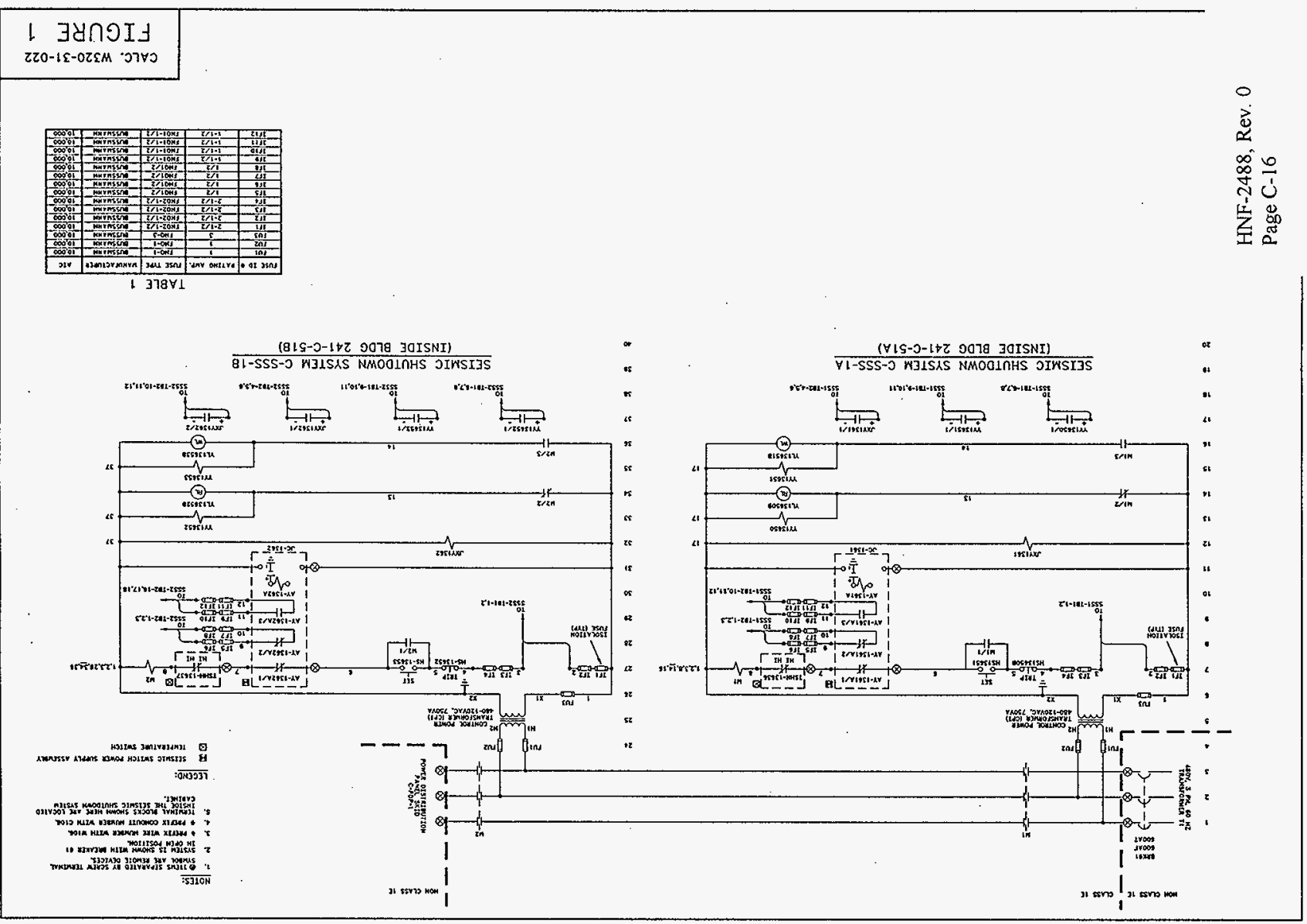




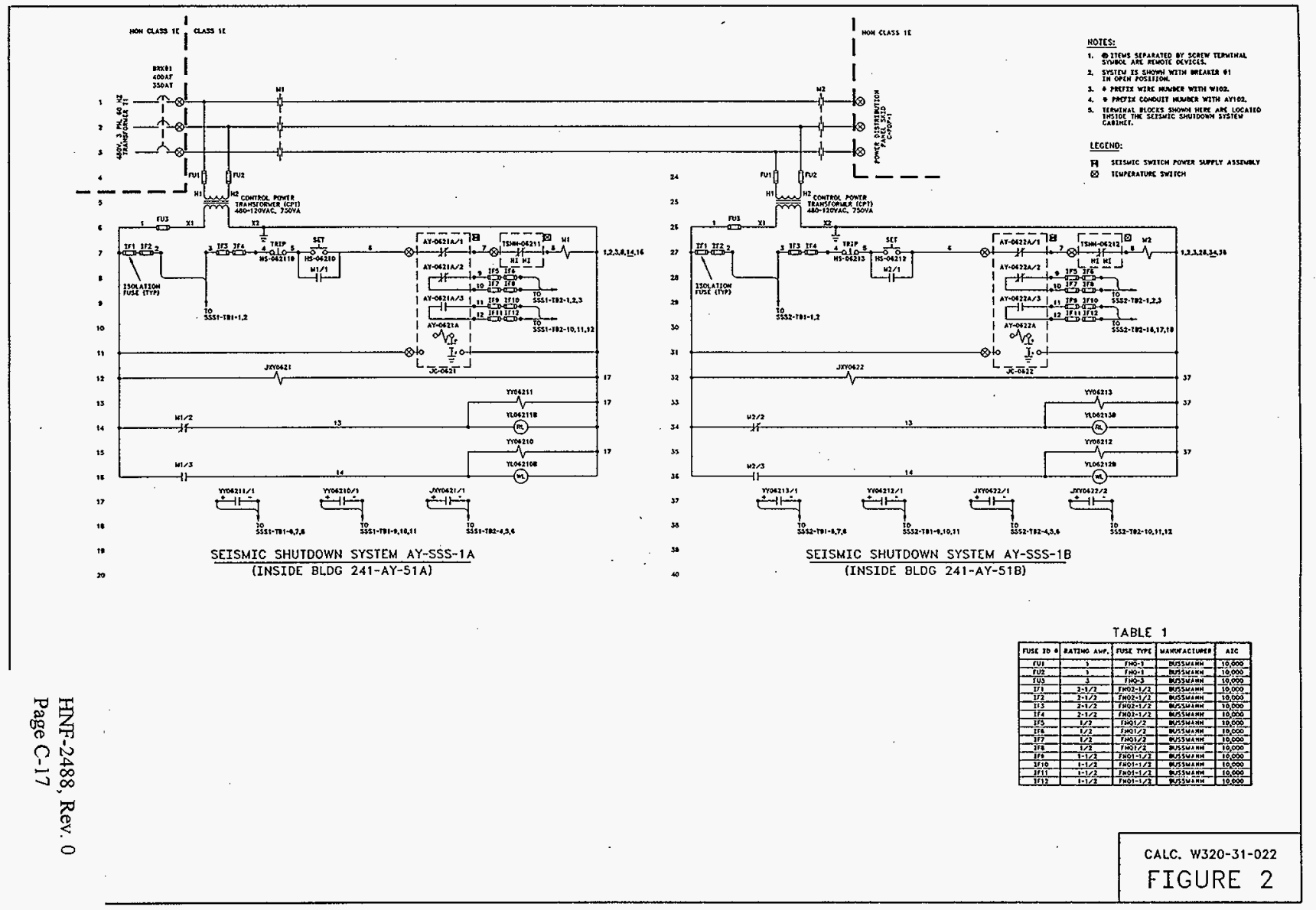



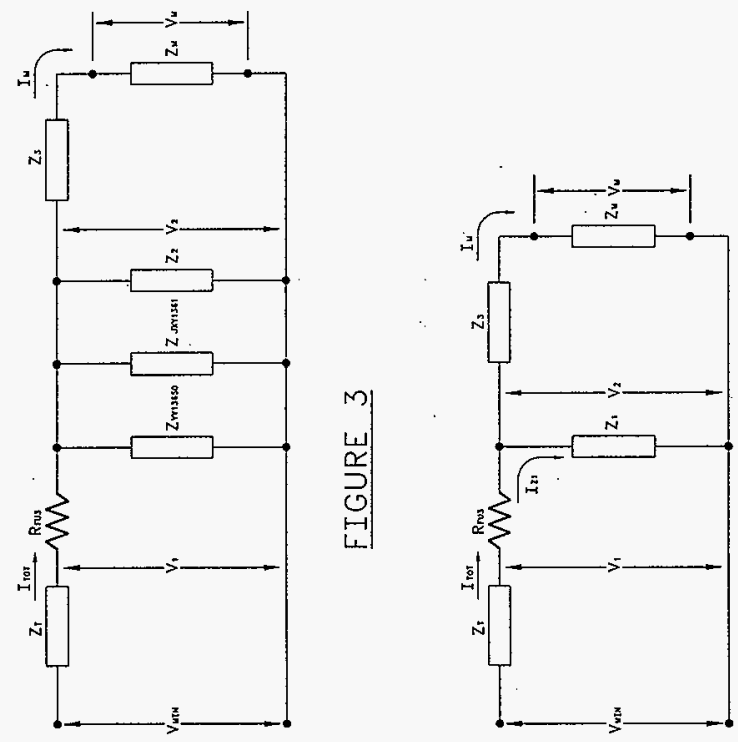

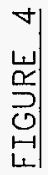

HNF-2488, Rev. 0

Page C-18 

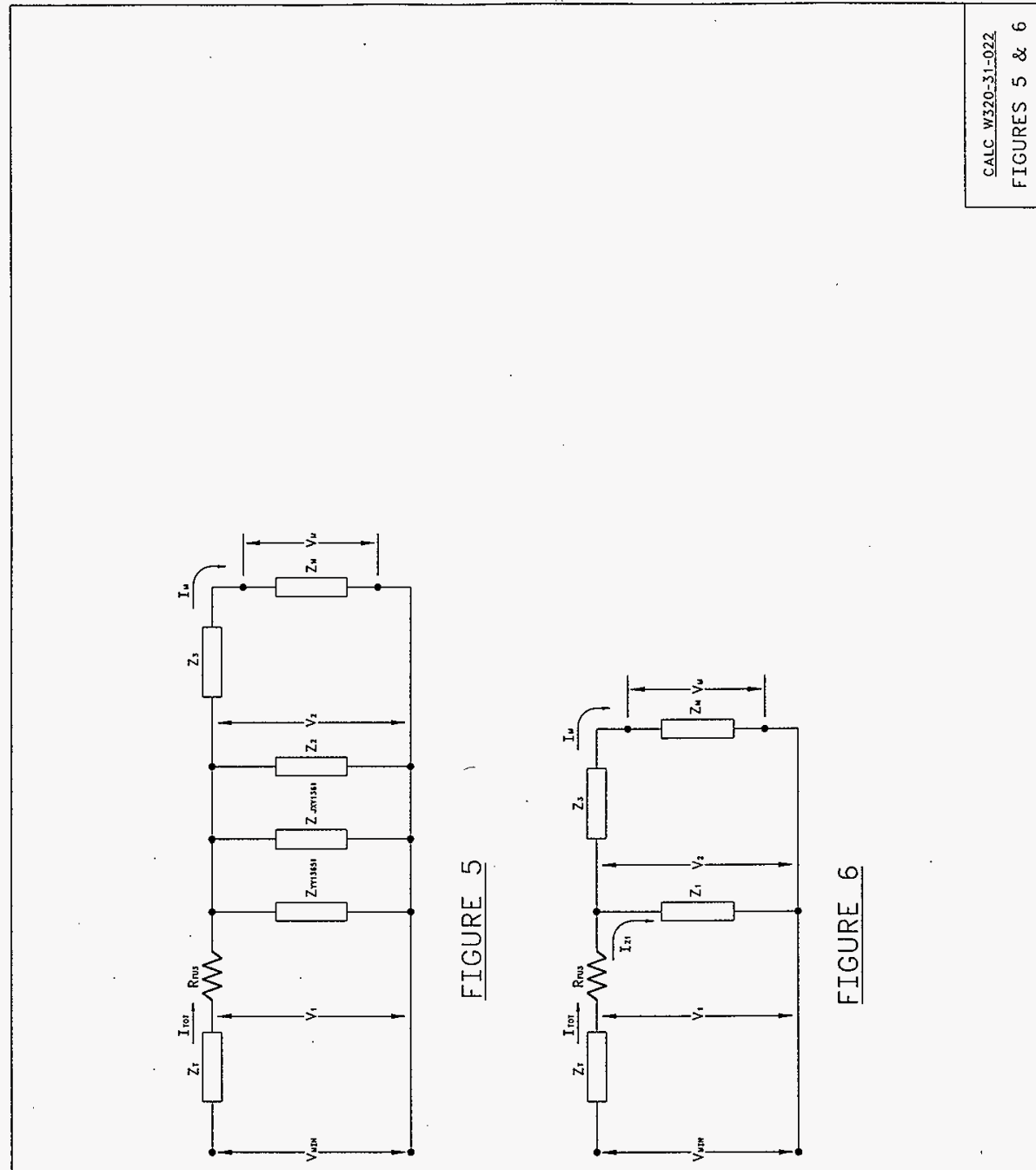

HNF-2488, Rev. 0

Page C-19 
358 CUNTACTORS, Full Voltage AC ATACHMENT: A Non-Reversing, Sizes 00-9 PAGE: A-1
Class A201

HNF-2488, Rev. 0 TS1

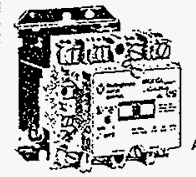

Page C-20

\begin{tabular}{|c|c|c|c|c|c|c|c|c|c|c|c|c|c|c|c|c|c|c|c|c|}
\hline \multirow{3}{*}{$\begin{array}{l}\text { Max. } \\
\text { Hp. }\end{array}$} & \multirow{3}{*}{$\begin{array}{l}\text { Motor } \\
\text { Volts }\end{array}$} & \multirow{3}{*}{$\begin{array}{l}\text { NEMA } \\
\text { Size }\end{array}$} & \multirow{3}{*}{$\begin{array}{l}\text { Cont. } \\
\text { Amps } \\
\text { Encl. }\end{array}$} & \multirow{3}{*}{$\begin{array}{l}\text { Coil } \\
\text { Votts }\end{array}$} & \multicolumn{4}{|l|}{2 Poles } & \multicolumn{4}{|l|}{3 Poles } & \multicolumn{4}{|l|}{4 Poles } & \multicolumn{4}{|l|}{5 Poles } \\
\hline & & & & & \multicolumn{2}{|l|}{ Open } & \multicolumn{2}{|c|}{ TYpe 1 Encl. } & \multicolumn{2}{|l|}{ Open } & \multicolumn{2}{|c|}{ Type 1 Encl. } & \multicolumn{2}{|l|}{ Open } & \multicolumn{2}{|c|}{ Type 1 Ench. } & \multicolumn{2}{|l|}{ Open } & \multicolumn{2}{|c|}{ TYpo I Encl. } \\
\hline & & & & & \begin{tabular}{|l|} 
Cat. \\
Number
\end{tabular} & $\begin{array}{l}\text { List } \\
\text { Prico }\end{array}$ & $\begin{array}{l}\text { Cat, } \\
\text { Number }\end{array}$ & \begin{tabular}{|l} 
List \\
Price
\end{tabular} & $\begin{array}{l}\text { Cal. } \\
\text { Number }\end{array}$ & \begin{tabular}{|l} 
List \\
Prico
\end{tabular} & \begin{tabular}{|l} 
Cat. \\
Number
\end{tabular} & $\begin{array}{l}\text { List } \\
\text { Price } \\
\end{array}$ & $\begin{array}{l}\text { Cat. } \\
\text { Number }\end{array}$ & \begin{tabular}{|l|} 
List \\
Prise
\end{tabular} & $\begin{array}{l}\text { Cat. } \\
\text { Number }\end{array}$ & \begin{tabular}{|l|l} 
List \\
Price
\end{tabular} & $\begin{array}{l}\begin{array}{l}\text { Cat. } \\
\text { Number }\end{array} \\
\end{array}$ & \begin{tabular}{|l|} 
List \\
Prise
\end{tabular} & $\begin{array}{l}\text { Cat. } \\
\text { Number }\end{array}$ & $\begin{array}{l}\text { List } \\
\text { Price } \\
\end{array}$ \\
\hline & & & & & A201 & & A.201 & & A201 & & A201 & & A20: & & A201 & & A201 & & A201 & \\
\hline $\begin{array}{l}11 / 2 \\
1 / 2 \\
2 \\
2 \\
\end{array}$ & $\begin{array}{l}200 \\
230 \\
460 \\
575 \\
\end{array}$ & 00 & 9 & $\begin{array}{l}120 \\
208 \\
240 \\
480 \\
600 \\
\end{array}$ & \begin{tabular}{|l|} 
KABA \\
KABB \\
KABW \\
KABX \\
KABE \\
\end{tabular} & $\begin{array}{ll}5 & 120 \\
\end{array}$ & \begin{tabular}{|l} 
SABA \\
SABB \\
SAEW \\
SABX \\
SAEE \\
\end{tabular} & \begin{tabular}{|ll}
5 & 132
\end{tabular} & \begin{tabular}{|l} 
KACA \\
KACB \\
KACW \\
KACX \\
XACE \\
\end{tabular} & \begin{tabular}{|ll}
5 & 139 \\
\end{tabular} & $\begin{array}{l}\text { SACA } \\
\text { SACB } \\
\text { SACW } \\
\text { SACX } \\
\text { SACE } \\
\end{array}$ & $\$ 150$ & $\begin{array}{l}\text { KADA } \\
\text { KADB } \\
\text { KAOW } \\
\text { KAOX } \\
\text { KADE } \\
\end{array}$ & $\begin{array}{ll}5 & 186 \\
\end{array}$ & $\begin{array}{l}\text { SADA } \\
\text { SADB } \\
\text { SADW } \\
\text { SADX } \\
\text { SADE } \\
\end{array}$ & $\$ 198$ & \begin{tabular}{|l} 
KAEA \\
KAEB \\
KAEW \\
KAEX \\
KAEE \\
\end{tabular} & $\$ 252$ & $\begin{array}{l}\text { SAEA } \\
\text { SAEB } \\
\text { SAEW } \\
\text { SAEX } \\
\text { SAEE }\end{array}$ & $\$ 264$ \\
\hline $\begin{array}{l}3 \\
3 \\
5 \\
5 \\
\end{array}$ & $\begin{array}{l}300 \\
230 \\
460 \\
575 \\
\end{array}$ & 0 & 18 & \begin{tabular}{|l|}
120 \\
208 \\
240 \\
480 \\
600 \\
\end{tabular} & $\begin{array}{l}\text { KOBA } \\
\text { KOBB } \\
\text { KOBW } \\
\text { KOBX } \\
\text { KOBE } \\
\end{array}$ & 156 & $\begin{array}{l}\text { SOBA } \\
\text { SOBB } \\
\text { SOBW } \\
\text { SOBX } \\
\text { SOBE } \\
\end{array}$ & 168 & $\begin{array}{l}\text { XOCA } \\
\text { XOCB } \\
\text { XOCW } \\
\text { XOCX } \\
\text { XOCE }\end{array}$ & 174 & $\begin{array}{l}\text { SOCA } \\
\text { SOCB } \\
\text { SOCW } \\
\text { SOCX } \\
\text { SOCE } \\
\end{array}$ & 186 & $\begin{array}{l}\text { KODA } \\
\text { KODB } \\
\text { KODW } \\
\text { KODX } \\
\text { KOOE }\end{array}$ & 222 & \begin{tabular}{|l} 
SOOA \\
SOOB \\
SOOW \\
SOOX \\
SOOE
\end{tabular} & 234 & $\begin{array}{l}\text { KOEA } \\
\text { KOEB } \\
\text { KOEW } \\
\text { KOEX } \\
\text { KOEE } \\
\end{array}$ & 288 & \begin{tabular}{|l} 
SOEA \\
SOEB \\
SOEW \\
SOEX \\
SOEE \\
\end{tabular} & 300 \\
\hline $\begin{array}{l}71 / 2 \\
71 / 2 \\
10 \\
10 \\
\end{array}$ & $\begin{array}{l}200 \\
230 \\
460 \\
575\end{array}$ & 1 & 27 & \begin{tabular}{|l|}
120 \\
208 \\
240 \\
480 \\
600 \\
\end{tabular} & \begin{tabular}{|l|} 
K1BA \\
K1BB \\
$K 1 B W$ \\
$K 18 X$ \\
K1BE \\
\end{tabular} & 186 & \begin{tabular}{|l} 
S18A \\
S18B \\
S1BW \\
S1BX \\
SIBE \\
\end{tabular} & 198 & $\begin{array}{l}\mathrm{KICA} \\
\mathrm{K} 1 \mathrm{CB} \\
\mathrm{K} 1 \mathrm{CW} \\
\mathrm{K} 1 \mathrm{CX} \\
\mathrm{KICE} \\
\end{array}$ & 204 & $\begin{array}{l}\text { SiCA } \\
\text { SiCB } \\
\text { SiCW } \\
\text { SiCX } \\
\text { SiCE }\end{array}$ & 216 & $\begin{array}{l}\text { K1OA } \\
\text { K108 } \\
\text { K10W } \\
\text { K1OX } \\
\text { KIDE }\end{array}$ & 252 & $\begin{array}{l}10 A \\
\text { S108 } \\
\text { SIDW } \\
\text { SIDX } \\
\text { SIDE } \\
\end{array}$ & 264 & \begin{tabular}{|l}
$K 1 E A$ \\
$K 1 E B$ \\
$K 1 E W$ \\
K1EX \\
KIEE \\
\end{tabular} & 318 & \begin{tabular}{|l|} 
SIEA \\
S1EB \\
S1EW \\
S1EX \\
SIEE \\
\end{tabular} & 330 \\
\hline $\begin{array}{l}10 \\
15 \\
25 \\
25 \\
\end{array}$ & $\begin{array}{l}200 \\
230 \\
460 \\
575\end{array}$ & 2 & 45 & \begin{tabular}{|l|}
200 \\
208 \\
240 \\
480 \\
600 \\
\end{tabular} & $\begin{array}{l}\mathrm{K} 2 \mathrm{BA} \\
\mathrm{K} 28 \mathrm{~K} \\
\mathrm{~K} 2 \mathrm{BW} \\
\mathrm{K} 28 \mathrm{X} \\
\mathrm{K} 2 \mathrm{BE} \\
\end{array}$ & 348 & \begin{tabular}{|l} 
S2BA \\
S2BB \\
\$2BW \\
S2EX \\
S2BE \\
\end{tabular} & 408 & \begin{tabular}{|l|}
$K 2 C A$ \\
$K 2 C B$ \\
$K 2 C W$ \\
$K 2 C X$ \\
$K 2 C E$ \\
\end{tabular} & 372 & \begin{tabular}{|l|} 
S2CA \\
S2CB \\
S2CW \\
S2CX \\
S2CE \\
\end{tabular} & 432 & $\begin{array}{l}\mathrm{K} 2 \mathrm{DA} \\
\mathrm{K} 2 \mathrm{DQ} \\
\mathrm{K} 2 \mathrm{OW} \\
\mathrm{K} 2 \mathrm{DX} \\
\mathrm{K} 2 \mathrm{OE} \\
\end{array}$ & 480 & $\begin{array}{l}\text { S2DA } \\
\text { S2DB } \\
S 20 W \\
S 20 X \\
\text { S2OE } \\
\end{array}$ & 540 & \begin{tabular}{|l} 
K2EA \\
K2EB \\
K2EW \\
K2EX \\
K2EE \\
\end{tabular} & 720 & $\begin{array}{l}\text { S2EA } \\
\text { S2ES } \\
\text { S2EW } \\
\text { S2EX } \\
\text { S2EE } \\
\end{array}$ & 780 \\
\hline $\begin{array}{l}25 \\
30 \\
50 \\
50 \\
\end{array}$ & $\begin{array}{l}\ldots \\
200 \\
230 \\
460 \\
575 \\
\end{array}$ & 3 & 90 & $\begin{array}{l}120 \\
203 \\
240 \\
480 \\
600 \\
\end{array}$ & $\begin{array}{l}\mathrm{K} 38 \mathrm{~A} \\
\mathrm{~K} 3 \mathrm{~B} \\
\mathrm{~K} 3 \mathrm{BW} \\
\mathrm{K} 3 \mathrm{BX} \\
\mathrm{K} 3 \mathrm{BE} \\
\end{array}$ & 552 & \begin{tabular}{|l} 
S3BA \\
S3B8 \\
S38W \\
$\$ 38 x$ \\
S38E \\
\end{tabular} & 672 & $\begin{array}{l}K 3 C A \\
K 3 C B \\
K 3 C W \\
K 3 C X \\
K 3 C E \\
\end{array}$ & 600 & \begin{tabular}{|l} 
S3CA \\
\$3CB \\
S3CW \\
S3CX \\
S3CE \\
\end{tabular} & 720 & $\begin{array}{l}\text { K30A } \\
\text { K30B } \\
\text { K3OW } \\
\text { K30X } \\
\text { K30E } \\
\end{array}$ & 768 & $\begin{array}{l}\text { S3DA } \\
\text { S3DB } \\
\text { S3OW } \\
\text { S3OX } \\
\text { S3OE }\end{array}$ & 888 & $\begin{array}{l}K 3 E A \\
K 3 E B \\
K 3 E W \\
K 3 E X \\
K 3 E E \\
\end{array}$ & 1152 & \begin{tabular}{|l} 
S3EA \\
S3EB \\
S3EW \\
S3EX \\
S3EE \\
\end{tabular} & 1272 \\
\hline $\begin{array}{r}40 \\
50 \\
100 \\
100 \\
\end{array}$ & $\begin{array}{l}200 \\
230 \\
460 \\
575\end{array}$ & 4 & 135 & $\begin{array}{l}120 \\
208 \\
240 \\
480 \\
600 \\
\end{array}$ & \begin{tabular}{|l|l|}
$K 4 B A$ \\
K4BB \\
K4BW \\
K4BX \\
K4BE \\
\end{tabular} & 1332 & $\begin{array}{l}\text { S4BA } \\
\text { S4BB } \\
\text { S4BW } \\
\text { S4BX } \\
\text { S4BE } \\
\end{array}$ & 1584 & $\begin{array}{l}\mathrm{KACA} \\
\mathrm{KGCO} \\
\mathrm{K} 4 \mathrm{CW} \\
\mathrm{KACX} \\
\mathrm{K} G \mathrm{CE} \\
\end{array}$ & 1440 & $\begin{array}{l}\text { SACA } \\
\text { SACB } \\
\text { S4CW } \\
\text { S4CX } \\
\text { S4CE } \\
\end{array}$ & 1692 & $\begin{array}{l}\text { K4DA } \\
\text { K4DB } \\
\text { K4DW } \\
\text { K4DX } \\
\text { K4DE } \\
\end{array}$ & 2004 & \begin{tabular}{|l|} 
S4DA \\
\$4DB \\
S4DW \\
S4DX \\
S4DE \\
\end{tabular} & 2256 & $\begin{array}{l}\text { K4EA } \\
\text { K4EB } \\
\text { K4EW } \\
\text { X4EX } \\
\text { K4EE }\end{array}$ & 2772 & $\begin{array}{l}\text { S4EA } \\
\text { S4EB } \\
\text { S4EW } \\
\text { S4EX } \\
\text { S4EE } \\
\end{array}$ & 3024 \\
\hline $\begin{array}{l}100 \\
200 \\
200 \\
\end{array}$ & $\begin{array}{l}330 \\
460 \\
575 \\
\end{array}$ & 5 & 270 & $\begin{array}{l}120 \\
240 \\
480 \\
600 \\
\end{array}$ & $\begin{array}{l}\text { K58A } \\
\text { K5BW } \\
\text { K5BX } \\
\text { K58E }\end{array}$ & 2886 & $\begin{array}{l}\text { SSBA } \\
\text { S5BW } \\
\text { SSBX } \\
\text { S5BE } \\
\end{array}$ & 3348 & $\begin{array}{l}\mathrm{KSCA} \\
\mathrm{KSCW} \\
\mathrm{K} \mathrm{CCX} \\
\mathrm{KSCE}\end{array}$ & 3138 & $\begin{array}{l}\text { SSCA } \\
\text { SSCW } \\
\text { SSCX } \\
\text { SSCE }\end{array}$ & 3600 & 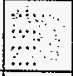 & & & $\because$ & $\begin{array}{c}\ddots \\
\ddots \\
\vdots\end{array}$ & 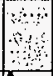 & $\mid$\begin{tabular}{ccc}
$\because$ & $\cdots$ \\
\hdashline & $\vdots$ \\
\hdashline & $\vdots$ \\
\hdashline & $\vdots$
\end{tabular} & $\begin{array}{r}\therefore \cdots \\
\because \cdots \\
\therefore \\
\therefore\end{array}$ \\
\hline $\begin{array}{l}200 \\
400 \\
400 \\
\end{array}$ & $\begin{array}{l}330 \\
460 \\
575 \\
\end{array}$ & 6 & 540 & \begin{tabular}{|l|}
120 \\
240 \\
480 \\
600 \\
\end{tabular} & $\begin{array}{l}\text { K6BA } \\
\text { K6BW } \\
\text { K6BX } \\
\text { K6BE } \\
\end{array}$ & 7344 & $\begin{array}{l}\text { S6BA } \\
\text { S68W } \\
\text { S68X } \\
\text { S68E } \\
\end{array}$ & 9378 & $\begin{array}{l}\mathrm{K} 6 \mathrm{CA} \\
\mathrm{K} 6 \mathrm{CW} \\
\mathrm{K} 6 \mathrm{CX} \\
\mathrm{K} 6 \mathrm{CE} \\
\end{array}$ & 8568 & $\begin{array}{l}\text { SGCA } \\
\text { SGCW } \\
\text { SGCX } \\
\text { SGCE }\end{array}$ & 10602 & $\mid$\begin{tabular}{cc}
$\cdots$ & $\vdots$ \\
\hdashline$\because$ & $\vdots$
\end{tabular} & & & & & & $\left(\begin{array}{cc}\ldots \\
\hdashline\end{array}\right.$ & $\because$ \\
\hline 300 & $\begin{array}{l}230 \\
460\end{array}$ & 7 & 810 & $\begin{array}{l}120 \\
240 \\
480\end{array}$ & $\begin{array}{l}K 78 J \\
K>8 K \\
K>8 U\end{array}$ & 10722 & $\begin{array}{l}\text { S7BS } \\
\text { S7BK } \\
\text { S7BU }\end{array}$ & 12756 & $\begin{array}{l}\mathrm{K}>\mathrm{CJ} \\
\mathrm{K} \mathrm{CK} \\
\mathrm{x}>\mathrm{Cu}\end{array}$ & 12228 & $\begin{array}{l}\text { S7C. } \\
\text { S7CK } \\
\text { S7CU }\end{array}$ & 14268 & \begin{tabular}{l}
$\alpha$ \\
\hdashline$\ldots$ \\
\hdashline$\ldots \ldots$ \\
\hdashline
\end{tabular} & & & & & $\therefore$ & $\left|\begin{array}{cc}1 & \\
\hdashline & \\
\hdashline & \\
\hdashline & \vdots \\
\hdashline & \vdots\end{array}\right|$ & $\begin{array}{l}\ddots \cdots \\
\because \cdots \\
\end{array}$ \\
\hline 50 & $\begin{array}{l}230 \\
460\end{array}$ & 8 & 1215 & $\begin{array}{l}120 \\
240 \\
480\end{array}$ & $\begin{array}{l}K 8 B J \\
K 8 B K \\
K 8 B U\end{array}$ & 17208 & $\begin{array}{l}\text { S88J } \\
S 88 K \\
\text { S88U }\end{array}$ & 20529 & $\begin{array}{l}K 8 \mathrm{CJ} \\
\times 8 \mathrm{CK} \\
\mathrm{K} 8 \mathrm{CU}\end{array}$ & 18876 & $\begin{array}{l}\text { S8CJ } \\
\text { S8CK } \\
\text { S8CU }\end{array}$ & 22212 & $\begin{array}{l}\therefore \therefore \\
\because \cdots \\
\cdots \cdots \\
\cdots \cdots \\
\end{array}$ & $\cdots$ & $\begin{array}{l}\cdots \cdots \\
\cdots \cdots \\
\cdots \cdots \\
\cdots \cdots \\
\cdots\end{array}$ & $\cdots$ & $\mid \begin{array}{l}\cdots \\
\cdots \\
\ldots \ldots\end{array}$ & $\therefore \therefore$ & $\begin{array}{l}\ldots . \\
\cdots \ldots \\
\cdots \cdots \\
\cdots\end{array}$ & . \\
\hline & & 9 & 2250 & 120 & $K G B J$ & 23040 & | $598 \mathrm{~J}$ & 25200 & $x a c$ & 25410 & [sacis & 28410 & & & & & & & & \\
\hline
\end{tabular}

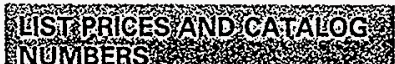
NUMBER

Rear Connected Contactors

120 Volt Rectified Coil/Open Only

\begin{tabular}{|l|l|l|}
\hline Size & Cat. No. & List Price \\
\hline 7 & A201K7CJ29 & $\$ 12928$ \\
8 & A201K8CJ79 & 19776 \\
9 & A201K9CJZ9 & 26610 \\
\hline
\end{tabular}

Electrical Components Division

February 1993

\begin{tabular}{|c|c|}
\hline \multirow{2}{*}{$\begin{array}{l}\text { Selling Policy 25-000 } \\
\text { Modification Kits, Accessories, } \\
\text { pages } 410-414 \\
\text { Factory Modifications, page } 415 \\
\text { Other Enclosures, page } 414 \\
\text { Dimensions, pages } 363,386 \\
\text { Other Available Coil Voltages, page } 419 \\
\text { Technical Data, pages } 417-419 \\
\text { instruction Leaflets: } \\
\text { Nonreversing, Reyersing }\end{array}$} & $\begin{array}{lc}\text { Size } 6 & 17053 \\
\text { Size 7-8 } & 17048 \\
\text { Size 9 } & 16978 \\
\text { Replacement Parts, page } 606 \\
\text { Discount C10-S1 }\end{array}$ \\
\hline & 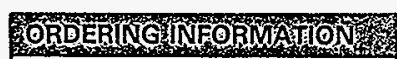 \\
\hline $\begin{array}{ll}\text { Nonreversing, Reversing } \\
\text { Size 00-0-1 } & 16960 \\
\text { Size 2 } & 16961 \\
\text { Size 3.4 } & 13238 \\
\text { Size 4 (Model K) } & 17001 \\
\text { Size 5 } & 17049\end{array}$ & $\begin{array}{l}\text { Order by catalog number. Complete cat- } \\
\text { alog number consists of A201 in bold } \\
\text { type in catalog number column, plus } \\
\text { suffix letters KABA, etc. in catalog num- } \\
\text { ber columin. Example: A201 + KABA = } \\
\text { A201KABA }\end{array}$ \\
\hline
\end{tabular}




\section{8 \\ SIAKIERS AND UUIUIALIURS ATTACHMENI Full Voltage AC, NEMA Sizes 00-9 Technical Data}

\begin{tabular}{|c|c|c|c|c|c|c|c|c|c|}
\hline \multicolumn{10}{|c|}{$\begin{array}{l}\text { Operating Coil Characteristics at Rated Coil Volts, Sizes } 00.9 \\
\text { The following represent typical production test values and should not be interpreted as a guarantee of actual performance. }\end{array}$} \\
\hline & Slze $00,0,1$ & Sizo 2 & Sizo 3 & Sizo 40 & Size 5 & Sizo 6 & $\operatorname{size}_{2}$ & Size 8 & size 9 \\
\hline 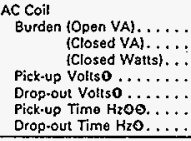 & $\begin{array}{c}160 \mathrm{VA} \\
25 \mathrm{VA} \\
7.8 \mathrm{~W} \\
85 \% \\
40-60 \% \\
1-11 / 2 \\
\% / 4-1 \\
\end{array}$ & $\begin{array}{c}160 \mathrm{VA} \\
25 \mathrm{VA} \\
7.8 \mathrm{~W} \\
85 \% \\
40-60 \% \\
11 / 2-2 \\
3 \%-1 \\
4\end{array}$ & $\begin{array}{l}625 \text { VA } \\
50 \text { VA } \\
18 W \\
85 \% \\
40-60 \% \\
2-21 / 2 \\
9 / 4-1\end{array}$ & $\begin{array}{l}700 \mathrm{VA} \\
64 \mathrm{VA} \\
21 \mathrm{~W} \\
85 \% \\
40-60 \% \\
1-11 / 2 \\
3 / 2-1\end{array}$ & $\begin{array}{c}1700 \mathrm{VA} \\
180 \mathrm{VA} \\
32 \mathrm{~W} \\
78 \% \\
65 \text { to } 75 \% \\
1.5 \\
0.75 \\
\end{array}$ & \begin{tabular}{|c}
$2900 \mathrm{VA}$ \\
$220 \mathrm{VA}$ \\
$42 \mathrm{~W}$ \\
$70 \%$ \\
$601070 \%$ \\
4.0 \\
0.75 \\
\end{tabular} & $\begin{array}{l}\text { (DC Operated } \\
\text { Only) } \\
\cdots \cdots \\
\cdots \cdots \\
\cdots \cdots \\
\cdots \cdots \\
\cdots \cdots \\
\end{array}$ & $\begin{array}{l}\text { (DC Operated } \\
\text { Oniy) } \\
\cdots \cdots \\
\cdots \cdots \\
\cdots \cdots \\
\cdots \cdots \\
\cdots \cdots\end{array}$ & $\begin{array}{l}\text { (DC Oparated } \\
\text { Oniy) } \\
\ldots \ldots \ldots \\
\cdots \ldots . . \\
\ldots \ldots . \\
\ldots \ldots .\end{array}$ \\
\hline 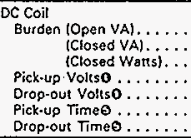 & $\begin{array}{l}17 \mathrm{VA} \\
17 \mathrm{VA} \\
18 \mathrm{~W} \\
80 \% \\
5-10 \% \\
\ldots \ldots \\
\ldots \ldots\end{array}$ & $\begin{array}{l}17 \mathrm{VA} \\
17 \mathrm{VA} \\
18 \mathrm{~W} \\
80 \% \\
5-10 \% \\
25-75 \mathrm{MS} \\
16-25 \mathrm{MS}\end{array}$ & $\begin{array}{l}35 \mathrm{VA} \\
35 \mathrm{VA} \\
35 \mathrm{~W} \\
80 \% \\
5-10 \% \\
25-75 \mathrm{MS} \\
16-25 \mathrm{MS}\end{array}$ & $\begin{array}{l}\ldots \ldots \\
35 \mathrm{~W} \\
80 \% \\
5-10 \% \\
25-75 \mathrm{MS} \\
16-25 \mathrm{MS}\end{array}$ & $\begin{array}{l}600 \mathrm{VA} \\
22 \mathrm{VA} \\
20 \mathrm{~W} \\
64 \% \\
18 \% \\
2.7 \mathrm{KzO} \\
9.3 \mathrm{HzO}\end{array}$ & $\begin{array}{c}2120 \mathrm{VA} \\
21 \mathrm{VA} \\
20 \mathrm{~W} \\
73 \% \\
13 \% \\
3 \mathrm{HzO} \\
17.5 \mathrm{HzO}\end{array}$ & $\begin{array}{l}400 \text { VA } \\
400 \text { VA } \\
400 \mathrm{~W} \\
45 \%-65 \% 0 \\
30 \%-45 \% 0 \\
21-41 \mathrm{HzOO} \\
7-12 \mathrm{HzOO}\end{array}$ & $\begin{array}{l}400 \text { VA } \\
400 \text { VA } \\
400 \mathrm{~W} \\
45 \%-65 \% \theta \\
30 \%-45 \% 0 \\
17-29 \mathrm{~Hz} \theta 0 \\
7-12 \mathrm{HzOO}\end{array}$ & $\begin{array}{l}2100 \mathrm{VA} \\
350 \mathrm{VA} \\
350 \mathrm{~W} \\
50 \%-65 \% \theta \\
40 \%-50 \% \Theta \\
16-18 \mathrm{Hz \theta O} \\
18-20 \mathrm{~Hz} \otimes 0\end{array}$ \\
\hline
\end{tabular}

NEMA Std. ICS $2-110$

Direct-current operated contactors shall withstand 110 percent of their rated voltage continuously without injury to the operating coils and shall close successfully at 80 percent of their rated voltage.

Alternating+current operated contactors shall withstand 110 percent of their rated voltage continuously without injury to the operating coils and shall close successfully at 85 percent of their rated voltage.

Mechanical Characteristics, Sizes 00-9

\begin{tabular}{|c|c|c|c|c|c|c|c|c|c|}
\hline & size 00,0,1 & Size 2 & Size 3 & Sizo 4 & Sizo 5 & Size 6 & Sizo 7 & Size 8 & Size 9 \\
\hline $\begin{array}{l}\text { Dimensions - Inches } \\
\text { Height } \ldots \ldots \ldots \ldots \ldots \ldots \ldots \\
\text { Width, } \ldots \ldots \ldots \ldots \ldots \ldots \ldots \\
\text { Depth. } \ldots \ldots \ldots \ldots \ldots \ldots \\
\end{array}$ & $\begin{array}{l}6.45 \text { ln. } \\
3.31 \\
4.51\end{array}$ & $\begin{array}{l}7.16 \mathrm{ln} . \\
3.31 \\
4.95\end{array}$ & $\begin{array}{l}\$ .93 \text { ln. } \\
4.62 \\
6.75\end{array}$ & $\begin{array}{l}\$ .93 \mathrm{In} . \\
4.62 \\
6.75 \\
\end{array}$ & $\begin{array}{l}12.00 \ln .0 \\
7.006 \\
7.750 \\
\end{array}$ & $\begin{array}{l}13.50 \ln .6 \\
7.006 \\
8.756 \\
\end{array}$ & $\begin{array}{l}18.62 \ln .6 \\
23.500 \\
11.006 \\
\end{array}$ & $\begin{array}{l}19.25 \ln .6 \\
23.506 \\
11.006 \\
\end{array}$ & $\begin{array}{l}25.00 \ln .6 \\
32.006 \\
13.006 \\
\end{array}$ \\
\hline 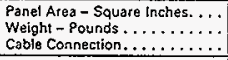 & $\begin{array}{l}21.35 \\
3.5 \mathrm{Lbs} . \\
\ldots\end{array}$ & $\begin{array}{l}23.7 \\
3.5 \mathrm{Lbs} \\
\ldots\end{array}$ & $\begin{array}{l}46.0 \\
11.5 \mathrm{Lbs} . \\
\cdots \\
\end{array}$ & $\begin{array}{l}46.0 \\
11.5 \mathrm{Lbs} . \\
\ldots . \\
\end{array}$ & $\begin{array}{l}84.0 \\
25 \text { Lbs. } \\
\text { Front }\end{array}$ & $\begin{array}{l}94.5 \\
42 \text { Lbs. } \\
\text { front }\end{array}$ & $\begin{array}{l}437.5 \\
215 \text { Los. } \\
\text { FronuRear }\end{array}$ & $\begin{array}{l}452.4 \\
265 \text { Lbs. } \\
\text { Front/Res }\end{array}$ & $\begin{array}{l}800 \\
315 \text { Lbs. } \\
\text { FronvRear }\end{array}$ \\
\hline $\begin{array}{l}\text { Maximum Cable Size/Phase } \\
\text { Copper (AWG/MCM) } \ldots \ldots \ldots \\
\text { Auxiliaty Electrical Circtits } \\
\text { Available } \ldots \ldots \ldots \ldots \ldots \ldots\end{array}$ & $\begin{array}{l}\# 6 \\
8\end{array}$ & $\begin{array}{l}\# 3 \\
6\end{array}$ & $\begin{array}{l}1.0 \\
6\end{array}$ & $\begin{array}{l}4 / 0 \\
6 \\
\end{array}$ & $\begin{array}{l}1.500 \mathrm{MCN} \\
4 \\
\end{array}$ & $\begin{array}{l}2-500 \mathrm{MCM} \\
4\end{array}$ & $\begin{array}{l}3-500 \mathrm{MCM} \\
3\end{array}$ & $\begin{array}{l}4.500 \mathrm{MCM} \\
3 \\
\end{array}$ & $\begin{array}{l}8.500 \mathrm{MCM} \\
4 . \\
\end{array}$ \\
\hline Latched Version Available..... & Yes & Yes & Yes & Yes & Yes & Yes & No & No & No \\
\hline 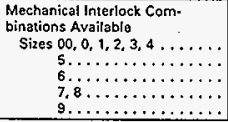 & $\begin{array}{l}\text { Vert., Horiz. } \\
\ldots \ldots \\
\ldots \ldots \\
\ldots \ldots \\
\ldots \ldots \\
\end{array}$ & $\begin{array}{l}\text { Vert., Horiz. } \\
\ldots \ldots \ldots \\
\ldots \ldots \ldots \\
\ldots \ldots \ldots \\
\ldots \ldots \\
\end{array}$ & $\begin{array}{l}\text { Verk., Horiz. } \\
\ldots \ldots \\
\ldots \ldots \\
\ldots \ldots \\
\ldots \ldots \\
\end{array}$ & $\begin{array}{l}\text { Vert., Horiz. } \\
\ldots \ldots \\
\ldots \ldots \\
\ldots \ldots \\
\ldots \ldots\end{array}$ & $\begin{array}{l}\text { Vert., Horiz. } \\
\text { Vert., Horiz. } \\
\text { Vert.. Horiz. } \\
\cdots \cdots . . \text {. } \\
\text { ….. }\end{array}$ & $\begin{array}{l}\text { Vert., Horiz, } \\
\text { Vert, Horiz. } \\
\text { Vertical } \\
\ldots \ldots \ldots \text {.... }\end{array}$ & $\begin{array}{l}\cdots \ldots \\
\text { Vertical } \\
\text { Vertical } \\
\text { Vertical }\end{array}$ & $\begin{array}{l}\cdots \ldots \\
\text { Vertical } \\
\text { Vertical } \\
\text { Vertical }\end{array}$ & $\begin{array}{l}\cdots \ldots \\
\cdots \cdots \\
\text { Yertical } \\
\text { Vertical }\end{array}$ \\
\hline
\end{tabular}

Data From Tables 430 - 147 Through 150 of 1987 N.E.C.

Motor Amperes at Full Loado, Three Phase AC

\begin{tabular}{|c|c|c|c|c|c|c|c|c|}
\hline \multirow[t]{2}{*}{$\mathrm{Hp}$} & \multicolumn{2}{|c|}{ Single Phasa AC } & \multicolumn{4}{|c|}{ Squisral Cage AC } & \multicolumn{2}{|l|}{$D C$} \\
\hline & $\begin{array}{l}115 \\
\text { Volts }\end{array}$ & $\begin{array}{l}230 \\
\text { Volts }\end{array}$ & $\begin{array}{l}200 \\
\text { Volls }\end{array}$ & $\begin{array}{l}230 \\
\text { Volts }\end{array}$ & $\begin{array}{l}460 \\
\text { Volis }\end{array}$ & $\begin{array}{l}575 \\
\text { Volts }\end{array}$ & $\begin{array}{l}120 \\
\text { Volts }\end{array}$ & $\begin{array}{l}240 \\
\text { Volis }\end{array}$ \\
\hline $\begin{array}{c}1 / 6 \\
1 / 4 \\
1 / 3 \\
1 / 2 \\
3 / 4 \\
1 \\
1 / 2 \\
2 \\
3 \\
5 \\
71 / 2 \\
10 \\
15 \\
20 \\
25 \\
30 \\
40 \\
50 \\
60 \\
75 \\
100 \\
125 \\
150 \\
200\end{array}$ & $\begin{array}{c}4.4 \\
5.8 \\
7.2 \\
9.8 \\
13.8 \\
16 \\
20 \\
24 \\
34 \\
56 \\
80 \\
100 \\
\ldots . \\
\ldots . \\
\ldots . \\
\ldots . \\
\ldots . \\
\ldots . \\
\ldots \ldots \\
\ldots . \\
\ldots . \\
\ldots . \\
\ldots . \\
\ldots .\end{array}$ & $\begin{array}{c}2.2 \\
2.9 \\
3.6 \\
4.9 \\
6.9 \\
8 \\
10 \\
12 \\
17 \\
28 \\
40 \\
50 \\
\ldots . \\
\ldots . \\
\ldots \ldots \\
\ldots . \\
\ldots . . \\
\ldots . \\
\ldots . \\
\ldots . \\
\ldots . \\
\ldots . \\
\ldots . \\
\ldots .\end{array}$ & $\begin{array}{c}\cdots \\
1.1 \\
\cdots \\
2.3 \\
3.2 \\
4.1 \\
6.0 \\
7.8 \\
11 \\
17.5 \\
25 \\
32 \\
48 \\
62 \\
78 \\
92 \\
120 \\
150 \\
177 \\
221 \\
230 \\
360 \\
414 \\
552\end{array}$ & $\begin{array}{c}\cdots \ldots \\
1 \\
\ldots \ldots \\
2 \\
2.8 \\
3.6 \\
5.2 \\
6.8 \\
9.6 \\
15.2 \\
22 \\
28 \\
42 \\
54 \\
68 \\
80 \\
104 \\
130 \\
154 \\
192 \\
248 \\
312 \\
360 \\
480\end{array}$ & $\begin{array}{c}\ldots \ldots \\
\ldots \ldots \\
\ldots \ldots \\
1 \\
1.4 \\
1.8 \\
2.6 \\
3.4 \\
4.8 \\
7.6 \\
11 \\
14 \\
21 \\
27 \\
34 \\
40 \\
52 \\
65 \\
77 \\
96 \\
124 \\
156 \\
180 \\
240\end{array}$ & $\begin{array}{r}\ldots \ldots . \\
\ldots \ldots . \\
\ldots .8 \\
1.1 \\
1.4 \\
2.1 \\
2.7 \\
3.9 \\
6.1 \\
9 \\
91 \\
17 \\
17 \\
22 \\
27 \\
32 \\
41 \\
52 \\
62 \\
77 \\
99 \\
125 \\
144 \\
192\end{array}$ & $\begin{array}{c}\ldots . . \\
3.1 \\
4.1 \\
5.4 \\
7.6 \\
9.5 \\
13.2 \\
17 \\
25 \\
40 \\
58 \\
76 \\
\ldots . \\
\ldots . \\
\ldots . . \\
\ldots . \\
\ldots . . \\
\ldots . \\
\ldots . . \\
\ldots . . \\
\ldots . . \\
\ldots . \\
\ldots . \\
\ldots . .\end{array}$ & $\begin{array}{r}1.6 \\
1.0 \\
2.7 \\
2.7 \\
3.8 \\
4.7 \\
6.6 \\
8.5 \\
12.2 \\
20 \\
29 \\
38 \\
55 \\
72 \\
89 \\
106 \\
140 \\
173 \\
206 \\
255 \\
341 \\
425 \\
506 \\
675\end{array}$ \\
\hline
\end{tabular}

O Percent of rated coil voltage.

(3) Lower figure when coil is cold. Higher figure when coil is hot.

- Drop-out time to clear arc. Time varies with type of load and contact wear.

- At 60 hertz base.

G To contact touch.

- For sizes 5.9 contactors oniy: for starter sizes 5.9

reler to Westinghouse.

0 Data pertains to Model K; for Model J, reler to Westinghouse.

o These current values are for motors running at usual speeds and with normal torque characteristics. Motors for spectal low speed or high torque may require higher current. In alt cases, heaters should be selected on basis of information on motor nameplate or motor card data. 


\section{L- Types AR 600 Volt Ac, ARD 600 Volt Dc, Convertible Contacts:

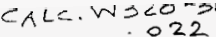 \\ ATTACHMENT: $B$ \\ $P A G C: B-1$}

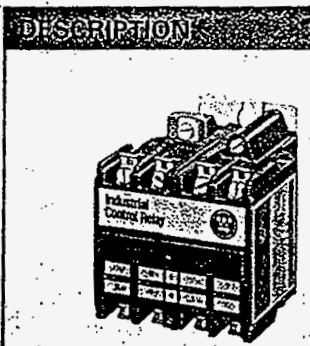

AR 4 Polo

\section{Application}

ARVARD relays are designed for use on

machirie tools, process lines, conveyors,

and similar automatic and semi-automatic equipment.

ARJARD relays are electro-mechanical convertible contact relays. AR relays are Ac devices, and the ARD is for $D C$

applications.

\section{Description}

Avạilable in either 4 or 6-pole configurations, AR relays are easily converted to 8 or 10 poles simply by adding a 4-pole deck, in addition, mechanical latch and pneumatic or solid state timer attach-

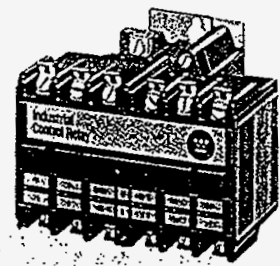

AR $\&$ Pole

ments are available for use with 4 and 6-pole relays.

Contacts are convertible from either NO to NC to provide any combination desired up to a maximum of 10, except that for the ARD, the number of $N C$ poles cannot exceed four in any pole configuration. Wide spacing of contacts simplifies installation, contect testing, and maintenance, Contacts are electrically and mechàrically isolated from each other. Overlap contacts are also available in one or two sets. These contacts should be mounted in the center pole positions. AC and $D c$ contact cartridges should not be used in the same relay.

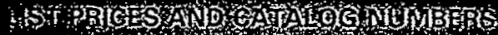

\section{ARIARD Relays}

\begin{tabular}{|c|c|c|c|c|c|c|c|}
\hline \multirow{3}{*}{$\begin{array}{l}\text { Number } \\
\text { ol Pols } \\
\text { Spoces }\end{array}$} & \multicolumn{3}{|c|}{ Contacts } & \multirow{2}{*}{\multicolumn{2}{|c|}{$\begin{array}{l}\text { AR } 600 \text { Volt Ac Reiars } \\
120 / 80,110 / 50 \text { AC Coil }\end{array}$}} & \multirow{2}{*}{\multicolumn{2}{|c|}{$\begin{array}{l}\text { ARD 6RO Volt De Relars } \\
120 \text { Voll De Coil }\end{array}$}} \\
\hline & \multirow[t]{2}{*}{ NO } & \multirow[t]{2}{*}{$\mathrm{NC}$} & \multirow{2}{*}{$\begin{array}{l}\text { Bank } \\
\text { Covities }\end{array}$} & & & & \\
\hline & & & & $\begin{array}{l}\text { Casalog } \\
\text { Murmber }\end{array}$ & $\begin{array}{l}\text { Ust. } \\
\text { Prica }\end{array}$ & $\begin{array}{l}\text { Cortalog } \\
\text { Number }\end{array}$ & $\begin{array}{l}\text { List } \\
\text { Price }\end{array}$ \\
\hline 4 & $\begin{array}{l}0 \\
2 \\
4 \\
\end{array}$ & $\begin{array}{l}0 \\
0 \\
0\end{array}$ & $\begin{array}{l}4 \\
2 \\
0 \\
\end{array}$ & $\begin{array}{l}\text { ARAA } \\
\text { AR420A } \\
\text { AR } 440 \mathrm{~A}\end{array}$ & & $\begin{array}{l}\text { AROA } 10: \\
\text { ARO420S: } \\
\text { ARD } 40 \text { S }\end{array}$ & \\
\hline 6 & $\begin{array}{l}0 \\
4 \\
6\end{array}$ & $\begin{array}{l}0 \\
0 \\
0\end{array}$ & $\begin{array}{l}6 \\
2 \\
0 \\
\end{array}$ & $\begin{array}{l}\text { AR6A } \\
\text { AR640A } \\
\text { AR66QA }\end{array}$ & & $\begin{array}{l}\text { ARD6S } \\
\text { ARD } \\
\text { ARDSESS }\end{array}$ & • \\
\hline 80 & $\begin{array}{l}6 \\
8 \\
\end{array}$ & 0 & $\begin{array}{l}2 \\
0\end{array}$ & $\begin{array}{l}A R 860 \hat{A} \\
A R B 8 C A\end{array}$ & & 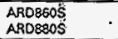 & \\
\hline 100 & 10 & $\overline{0}$ & 0 & ARTOTOOA & & ARO10100S & \\
\hline
\end{tabular}

Contact Cartridges

\begin{tabular}{|c|c|c|c|c|}
\hline \multirow{2}{*}{$\begin{array}{c}\text { Type Terminal } \\
.\end{array}$} & \multicolumn{2}{|c|}{ Standard Contact Cartridges } & \multicolumn{2}{|c|}{ Overipp contset Gortridges } \\
\hline & $\begin{array}{l}\text { Catalea } \\
\text { Number }\end{array}$ & $\begin{array}{l}\text { Ust } \\
\text { Priceo }\end{array}$ & $\begin{array}{l}\text { Catalog } \\
\text { Numbero }\end{array}$ & $\begin{array}{l}\text { List } \\
\text { Prices }\end{array}$ \\
\hline \multicolumn{5}{|l|}{ 600 Volt Ae Cartridges } \\
\hline $\begin{array}{l}\text { With Cramp Terminals } \\
\text { With Screw Terminals }\end{array}$ & $\begin{array}{l}\text { ARC } \\
\text { AACR }\end{array}$ & $\cdot$ & AROC & c \\
\hline \multicolumn{5}{|c|}{ Go0 Volt De Cintridges $\because \cdots, \because, \cdots$} \\
\hline $\begin{array}{l}\text { With Comp Terminols } \\
\text { Writh Scrow Terminals }\end{array}$ & ARDC & : & $\begin{array}{l}\text { AROOC } \\
\text { AROOCR }\end{array}$ & \\
\hline
\end{tabular}

- Standard cartridges a re sold in cartoris of 4 cartridges, Catalog numbet and liet price ace for single cartridge. - Overlap contact cortridges aro sold in sets of 2 cartridges. Cotelog number and list price are for sets of 2. o Will not accept top mounced istch or timers.

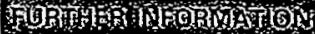

HNF-2488, Rev. 0

Page C-22
Discount C10-S12

CSA File No. LR39402-6, LR54517, and LR54520
Contact Ratings

600 Volt Ac Cartridges NEMA A600

\begin{tabular}{|l|l|l|l|l|l|l|}
\hline Volts & Cont & \multicolumn{2}{|c|}{ Max. Current } & \multicolumn{2}{|c}{ Max. VA } \\
\cline { 3 - 6 } & Current & Make & Break & Make & Break \\
\hline 120 & 10 & 60 & 6 & 7200 & 720 \\
240 & 10 & 30 & 3 & 7200 & 720 \\
480 & 10 & 15 & 15 & 7200 & 720 \\
600 & 10 & 15 & 12 & 1.2 & 7200 & 720 \\
\hline
\end{tabular}

Dc Cartridges NEMA P600

\begin{tabular}{|c|c|c|c|}
\hline \multirow[t]{2}{*}{ Volts } & \multirow{2}{*}{$\begin{array}{l}\text { Cont: } \\
\text { curront }\end{array}$} & Max current & $\operatorname{Max} V A$ \\
\hline & & Make of Break & Make or Break \\
\hline $\begin{array}{l}125 \\
250 \\
600\end{array}$ & $\begin{array}{rll}5 & \\
5 & \\
5 & \ldots\end{array}$ & $\begin{array}{l}1.1 \\
.55 \\
.20\end{array}$ & $\begin{array}{l}138 \\
138 \\
138\end{array}$ \\
\hline
\end{tabular}

Resistive Load

$125 \mathrm{~V} 0 \mathrm{C}$ 3.0 amps

250V:DC: 7.5 amps

Coil Power Requiremèts

Ac: 96 VA open, 14 VA close

Dc: 14 watts open, 250 volts max.

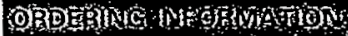

- Order by catalog number. AR relays listed have $120 / 110$ volt, $60 / 50 \mathrm{~Hz}$ coils, and ARO relays have 120 volt Dc coils.

- If a different coil voltage is requited, select the catalog letter from the coil Voltage Table beiow and substitute it for the SAACED letter in the catalog number.

- $A R$ and ARO relays listed are supplied with NO contacts which are easily converted to NC. If both NO and NC poles are required, order by catalog number. Example: 4 pole relay with 1 NO and 3 NC contacts, order AR413A. Add $\$ 12$ list per relay.

- SCREW Terminats - For ring-type connectors, add Suffix $R$ to the catalog number. Example: AR420AR. No additional charge.

- OVERLAP Contacts - Overlap contacts for AR and ARD relays are designed so that a normally open contact closes before the correspond. ing normaliy closed contact opens. Overlap contacts.come in NO/NC sets of two cartridges. Add catalog letter Suffix $s$ to the catalog number. Exam ple: AR420AS. Specify the number of sets requitred: S for one sèt and $\mathbf{S} 2$ for two sets. Add $\$ 12$ list per set.

Coil Voltage Tabie

\begin{tabular}{|c|c|c|c|c|}
\hline \multicolumn{3}{|l|}{ AR Coils } & \multicolumn{2}{|c|}{ ARO Coils } \\
\hline $\begin{array}{l}\text { Yolts } \\
\text { Ac }\end{array}$ & $\mathrm{Hz}$ & $\begin{array}{l}\text { Cotaiog } \\
\text { Sutfix }\end{array}$ & $\begin{array}{l}\text { Votts } \\
\text { De }\end{array}$ & $\begin{array}{l}\text { Catalos } \\
\text { Suffix }\end{array}$ \\
\hline $\begin{array}{l}12 \\
24 \\
48 \\
110 \\
208 \\
240220 \\
277 \\
440 / 380 \\
4804440 \\
550 \\
600 / 550\end{array}$ & $\begin{array}{l}60 \\
60 \\
60 \\
60: \\
60 \\
60.50 \\
60 . \\
6050 \\
6050 \\
60 . \therefore \\
60.50\end{array}$ & 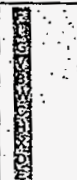 & $\begin{array}{r}12 \\
24 \\
: 48 \\
: 95 \\
130 \\
240\end{array}$ & $\begin{array}{l}\mathrm{P} \\
\mathrm{M} \\
\mathrm{B} \\
\mathrm{u}\end{array}$ \\
\hline
\end{tabular}




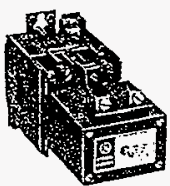

CR120BL latched relay

\section{CR120BL Latched Relays}

Forms listed below have captive terminal clamps and convertible contact modules. OC forms are available. Contact nearest GE Electrical Distribution \& Control sales office for information.

\begin{tabular}{|c|c|c|c|c|}
\hline \multicolumn{3}{|c|}{ No of Poles (1) } & \multirow{2}{*}{$\begin{array}{l}\text { Catalog Number } \\
\text { AC Open Forms }\end{array}$} & \multirow{2}{*}{$\begin{array}{l}\text { Hst Price, } \\
\text { G0-1004 }\end{array}$} \\
\hline Total & NO & NC & & \\
\hline 2 & $\begin{array}{l}2 \\
1 \\
0\end{array}$ & $\begin{array}{l}0 \\
1 \\
2 \\
\end{array}$ & $\begin{array}{l}\text { CR1208LO20". } \\
\text { CR1208LO11:. } \\
\text { CR120BL002" }\end{array}$ & $\therefore \begin{array}{r}5156.00 \\
\therefore \quad 168.00 \\
168.00\end{array}$ \\
\hline 3 & $\begin{array}{l}3 \\
2 \\
1 \\
0 \\
\end{array}$ & $\begin{array}{l}0 \\
1 \\
2 \\
3 \\
\end{array}$ & 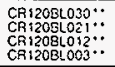 & \begin{tabular}{l}
1168.00 \\
$\because 180.00$ \\
\hdashline$\quad 180.00$ \\
\hdashline
\end{tabular} \\
\hline 4 & $\begin{array}{l}4 \\
3 \\
2 \\
1 \\
0\end{array}$ & $\begin{array}{l}0 \\
1 \\
2 \\
3 \\
4 \\
\end{array}$ & 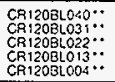 & $\begin{array}{r}\quad 180.00 \\
\because \quad 192.00 \\
192.00 \\
\quad 192.00 \\
\because 192.00 \\
\end{array}$ \\
\hline 6 & $\begin{array}{l}6 \\
5 \\
4 \\
3 \\
2 \\
1 \\
0\end{array}$ & $\begin{array}{l}0 \\
1 \\
2 \\
3 \\
4 \\
5 \\
6 \\
\end{array}$ & 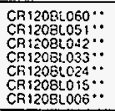 & $\begin{array}{r}\quad 204.00 \\
216.00 \\
216.00 \\
216.00 \\
216.00 \\
216,00 \\
216.00\end{array}$ \\
\hline 8 & $\begin{array}{l}8 \\
7 \\
6 \\
5 \\
4 \\
3 \\
2 \\
1 \\
0\end{array}$ & $\begin{array}{l}0 \\
1 \\
2 \\
3 \\
4 \\
5 \\
6 \\
7 \\
8 \\
8\end{array}$ & 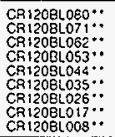 & $\begin{array}{r}228.00 \\
240.00 \\
240.00 \\
240.00 \\
240.00 \\
240.00 \\
240.00 \\
240.00 \\
240.00\end{array}$ \\
\hline
\end{tabular}

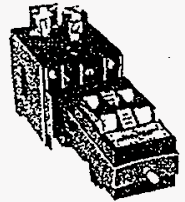
600 Volts $50 / 60$ Heriz

CR122B preumatic time-delay relay

\section{** AC Coil Suffix Table}

(Insert where "* appears in Catalog Number, ac relays only) $A C$ coil suffixes are the same for ac relays, including standard. pneumatic time delay, and latch.

\begin{tabular}{|c|c|c|c|c|c|c|c|c|c|}
\hline FicQuency & $24 \mathrm{~V}$ & $115 \mathrm{~V}$ & $120 \mathrm{~V}$ & $200 \mathrm{~V}$ & $208 \mathrm{~V}$ & $230 \mathrm{~V}$ & $460 \mathrm{~V}$ & $575 \mathrm{~V}$ & $600 \mathrm{~V}$ \\
\hline $60 \mathrm{~Hz}$ & 25 & 02 & 220 & 23 & 24 & 03 & 04 & 05 & 06 \\
\hline \multirow{3}{*}{$50 \mathrm{~Hz}$} & $24 \mathrm{~V}$ & $110 \mathrm{~V}$ & $220 \mathrm{~V}$ & $380 \mathrm{~V}$ & $440 \mathrm{~V}$ & $550 \mathrm{~V}$ \\
\cline { 2 - 9 } & 26 & 07 & 08 & 04 & 09 & 10 \\
\hline
\end{tabular}

(1) Coil 22 is dual rated for 120 -Volts, 60 -Heriz/110-Volis, 50 -Heriz operation.

t† DC Coil Suffix Table

(Insert where tt appears in Catalog Number, de relays only)

\begin{tabular}{|c|c|c|c|c|}
\hline $12 \mathrm{~V}$ & $24 \mathrm{~V}$ & $48 \mathrm{~V}$ & $64 \mathrm{~V}$ & $125 \mathrm{~V}$ \\
\hline 14 & 48 & 49 & 45 & 41 \\
\hline
\end{tabular}

\section{Coil Data}

\begin{tabular}{|l|c|c|c|}
\hline & intush VA & Sealed VA & Sealed Wais \\
\hline AC Relay coil & 120 & 15 & 7 \\
AC Uniach coil & 31 & 15 & 92 \\
OC Reiay coit & 235 & 2.8 & 2.8 \\
\hline
\end{tabular}

\section{Contact Ratings - All Relays}

\begin{tabular}{|c|c|c|c|c|c|c|c|c|c|}
\hline \multirow[t]{2}{*}{$\begin{array}{c}\text { Type } \\
\text { of } \\
\text { Coniacls }\end{array}$} & \multirow[t]{2}{*}{$\begin{array}{l}\text { Max. AC } \\
\text { Vollage }\end{array}$} & \multirow{2}{*}{$\begin{array}{l}\text { Whax. } \\
\text { Conin. } \\
\text { yous } \\
\text { Faling } \\
\text { Arnps }\end{array}$} & \multicolumn{2}{|c|}{$\begin{array}{c}\text { Max, AC } \\
\text { Volliampere } \\
\text { Rating }\end{array}$} & \multicolumn{2}{|c|}{$\begin{array}{l}\text { Max. AC } \\
\text { Rating } \\
\text { Amps }\end{array}$} & \multicolumn{2}{|c|}{$\begin{array}{l}\text { Max. } O C \\
\text { Rating } \\
\text { Amps }\end{array}$} & \multirow{2}{*}{$\begin{array}{c}\text { Max, OC } \\
\text { Vollampere } \\
\text { faling }\end{array}$} \\
\hline & & & Make & Break & Make & Break & $125 \mathrm{~V}$ & $250 \mathrm{~V}$ & \\
\hline Insil. & 6 & 10 & 7200 & 320 & 60 & 6 & 1.1 & 0.55 & 138 \\
\hline Delay & 600 & 5 & 3600 & 360 & 30 & 3 & 0.5 & - & - \\
\hline
\end{tabular}

(2) Use for CR1208 and CR1228T conlact rating.

\section{CR122B Pneumatic Time-delay Relays}

All Forms have 1NO-1NC time delay contacts(3). Listed forms are field convertible from TDE to TDD and vice versa. DC forms are available. Contact nearest GE Electrical Distribution \& Control sales office for information.

\begin{tabular}{|c|c|c|c|c|c|c|c|}
\hline \multirow{2}{*}{\multicolumn{3}{|c|}{$\begin{array}{l}\text { Number of Inslantaneous } \\
\text { Auxiliary Conlacts }\end{array}$}} & \multicolumn{4}{|c|}{ Calalog Number AC forms } & \multirow{3}{*}{$\begin{array}{c}\text { Lust } \\
\text { Prico, } \\
\text { Go-10G4 }\end{array}$} \\
\hline & & & \multicolumn{2}{|c|}{ Time Delay on Energization } & \multicolumn{2}{|c|}{ Fime Delay on Denenergization } & \\
\hline Total & No & NC & $\begin{array}{c}\text { Time Range } \\
\text { o? } 2 \text {-60 Seconds }\end{array}$ & $\begin{array}{l}\text { Tume fiange } \\
5.200 \text { Seconds }\end{array}$ & $\begin{array}{l}\text { Torie Range } \\
\text { o2-60 Seconds }\end{array}$ & $\begin{array}{c}\text { Tirne Range } \\
\text {-5-200 Seconds }\end{array}$ & \\
\hline None & - & - & $\mathrm{CR} 122 \mathrm{~B} 000^{\circ} \mathrm{A}$ & CR1228000 ${ }^{\prime} B$ & CR $1228000 \cdot \varepsilon$ & CR1228000. $\mathrm{F}$ & $\$ 216.00$ \\
\hline 2 & $\begin{array}{l}2 \\
1 \\
0 \\
\end{array}$ & $\begin{array}{l}0 \\
1 \\
2 \\
\end{array}$ & $\begin{array}{l}\text { CF1228020 }{ }^{A} \\
\text { CA1228011 } \\
\text { CR1228002 }{ }^{A} \\
\end{array}$ & 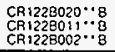 & $\begin{array}{l}\text { CR1228020 *E } \\
\text { CR1228019 } \\
\text { CR122B002 *E }\end{array}$ & $\begin{array}{l}\text { CR1228020**F } \\
\text { CR1228011*:F } \\
\text { CFI228002*F }\end{array}$ & $\begin{array}{r}\because 240.00 \\
\therefore \quad 25200 \\
\because \quad 25200\end{array}$ \\
\hline 3 & $\begin{array}{l}3 \\
2 \\
1 \\
0 \\
\end{array}$ & $\begin{array}{l}0 \\
1 \\
2 \\
3 \\
\end{array}$ & $\begin{array}{l}C A 122 B 030 \cdots A \\
C A 122 B 021 \cdots_{A} \\
C R 122 B 012 \cdot \cdots A \\
C R 1228003 \cdots A\end{array}$ & 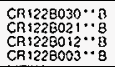 & $\begin{array}{l}C R_{1228030} \cdots E \\
C R 1223021 \cdots E \\
C R 122 B 012 \cdots E \\
C R 122 B 003 \cdots E\end{array}$ & 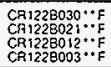 & $\begin{array}{r}252.00 \\
-256.00 \\
-264.00 \\
266.00\end{array}$ \\
\hline 4 & $\begin{array}{l}4 \\
3 \\
2 \\
1 \\
0\end{array}$ & $\begin{array}{l}0 \\
1 \\
2 \\
3 \\
4\end{array}$ & 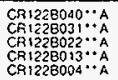 & 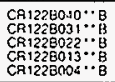 & 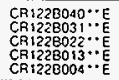 & 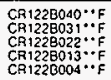 & $\begin{array}{l}\because 264.00 \\
\because 276.00 \\
\because 276.00 \\
\because 276.00 \\
\because 276.00\end{array}$ \\
\hline
\end{tabular}

* "Insert coil number from AC Coil Suffix Table to complete Calalog Number.

References:

Instructions:

GEH-4115 (AC Relays)

GEH-4120 (Latch Relays)

GEH-4143 (DC Relays)
References:

Inslructions: (TIme-delay Relays)

GEH.4119 (CR122BT Relays)

GEH-4147 (CR122B Relays) 
Technical Data

HNF-2488, Rev. 0

Page C-24
CALC. W32O-31-022

ATACH MENT: $C$

PAGE : $\mathrm{C}-1$

Typical Data for 600 Voit Class Dry-Type Transformer

\begin{tabular}{|c|c|c|c|c|c|c|c|c|c|c|c|c|c|c|c|c|}
\hline \multirow[t]{2}{*}{$x V A$} & \multirow[t]{2}{*}{ Type } & \multirow{2}{*}{\begin{tabular}{l|} 
Deg. C \\
Rise
\end{tabular}} & \multicolumn{5}{|c|}{ Dimensions, (In.) } & \multicolumn{2}{|c|}{$\begin{array}{l}\text { Losses in } \\
\text { Watts }\end{array}$} & \multicolumn{4}{|c|}{ Elficiency } & \multicolumn{3}{|c|}{$\%$ Regulation } \\
\hline & & & Height & Width & Depth & $\begin{array}{l}\text { Weight } \\
\text { (Alum) } \\
\text { Lbs. }\end{array}$ & $\begin{array}{l}\text { Weight } \\
\text { (Cu.) } \\
\text { Lbs. }\end{array}$ & N.L. & Total & Load & $\begin{array}{l}\text { 1/2 } \\
\text { Load }\end{array}$ & $\begin{array}{l}3 / 4 \\
\text { Load }\end{array}$ & $\mid \begin{array}{l}\text { Full } \\
\text { Load }\end{array}$ & $\begin{array}{l}100 \% \\
\text { P.F. }\end{array}$ & $\begin{array}{l}80 \% \\
\text { P.F. }\end{array}$ & $\%$ imp. \\
\hline 0.25 & EP & 80 & $71 / 16$ & $4 \%$ & $4 \%$ & & 12 & 13 & 36 & 80.0 & 82.0 & 85.0 & 87.5 & 9.2 & 8.0 & 9.24 \\
\hline 0.5 & & 80 & $7 / 118$ & $4 \%$ & $4^{4} / 8$ & & 13 & 20 & 45 & 85.2 & 90.5 & 91.6 & 91.8 & 5.07 & 4.54 & 5.12 \\
\hline 0.75 & & 80 & $83 / 2$ & 6 & $5 \%$ & & 20 & 21 & 54 & 89.1 & 92.8 & 93.5 & 93.3 & 4.14 & 3.33 & 4.44 \\
\hline 1 & & 80 & $83 \%$ & 6 & $51 / 2$ & & 30 & 29 & 71 & 95.2 & 95.0 & \begin{tabular}{|l|}
96.0 \\
\end{tabular} & \begin{tabular}{|l|}
95.1 \\
\end{tabular} & 4.09 & 3.62 & 4.18 \\
\hline 1.5 & & 80 & $10 \frac{1 / 2}{2}$ & $6 \%$ & $6 \%$ & & 40 & 37. & 92 & 94.5 & 95.5 & 95.1 & 94.3 & 3.83 & 3.60 & 3.70 \\
\hline 2 & & 80 & $101 / 2$ & $63 / 6$ & $61 / 8$ & & 40 & 37 & 97 & 95.4 & 96.5 & 96.4 & 96.0 & 3.18 & 3.30 & 3.42 \\
\hline 3 & & 115 & $14 \%$ & $711 / 15$ & 8 & 65 & 69 & 74 & 144 & 95.0 & 96.3 & 96.3 & 95.9 & 3.25 & 3.50 & 3.53 \\
\hline 5 & & 115 & 16 & $10^{3 / 8}$ & $9 \%$ & 113 & 120 & 104 & 201 & 96.6 & 97.35 & 97.2 & 96.85 & 2.58 & \begin{tabular}{|l|}
2.50 \\
\end{tabular} & 2.64 \\
\hline 7.5 & & 115 & 16 & $10 \%$ & $9 \%$ & 123 & 133 & 149 & 271 & 97.0 & 97.65 & 97.5 & 97.15 & 2.31 & 2.50 & 2.54 \\
\hline 10 & & 115 & 19 & $13 \%$ & $10 \frac{1}{2}$ & 193 & 208 & 160 & 317 & 96.1 & 97.3 & 97.4 & 97.25 & 1.95 & 2.10 & 2.18 \\
\hline 15 & & 115 & 19 & $13 \%$ & $10 \frac{1}{2}$ & 216 & 235 & 230 & 454 & 97.6 & 98.15 & 98.1 & 97.8 & 1.71 & 1.80 & 1.85 \\
\hline 25 & & 115 & $225 / 18$ & $16 \%$ & $14 \% / 8$ & 385 & 414 & 284 & 550 & 97.3 & 98.0 & 98.0 & 97.8 & 1.18 & 1.63 & 1.65 \\
\hline 3 & EPT & 115 & $133 \%$ & $15^{13 / 66}$ & $85 / 18$ & 196 & 123 & 121 & 183 & 94.2 & 34.75 & 94.0 & 92.9 & 6.73 & 7.9 & 7.93 \\
\hline 6 & $-U^{\prime}$ & 115 & $15 \%$ & $16 \%$ & $9 \%$ & 143 & 153 & 140 & 288 & 93.6 & \begin{tabular}{|l}
95.3 \\
\end{tabular} & 95.2 & 94.8 & 3.35 & 3.6 & 3.7 \\
\hline 9 & (i) & 115 & $15 \%$ & $16 \% / 2$ & $9^{3 / / 9}$ & 166 & 178 & 199 & 412 & 96.0 & $96.8 \mathrm{r}$ & 96.7 & 96.2 & 3.07 & 3.4 & 2.96 \\
\hline 15 & 4 & 115 & $17 \%$ & $19^{1 / 1 / 8}$ & $10^{2 / 16}$ & 275 & 300 & 216 & 534 & 36.9 & 97.5 & 97.4 & 97.0 & 2.38 & 2.91 & \begin{tabular}{|l|}
2.8 \\
\end{tabular} \\
\hline 30 & 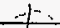 & 115 & $265 / 8$ & $25 \%$ & $12^{3 / 4}$ & 422 & 504 & 229 & 681 & 96.7 & \begin{tabular}{|l|l|}
97.8 \\
\end{tabular} & 97.9 & 97.8 & $1.51^{\circ}$ & 2.12 & 2.14 \\
\hline 25 & DS-3; & 150 & $37 \%$ & $221 / 2$ & 20 & 310 & 360 & 200 & 1050 & 96.1 & 96.8 & 96.6 & 96.0 & 3.5 & 4.0 & 4.0 \\
\hline $37: 5$ & & 150 & $43 \%$ & $221 / 2$ & 20 & 375 & 450 & 250 & 1550 & 96.1 & 96.8 & 96.5 & 96.0 & 3.5 & 5.1 & 5.2 \\
\hline$(50)$ & & 150 & $43 \%$ & $221 / 2$ & 20 & 425 & 500 & 300 & 1950 & 96.8 & 97.2 & 36.8 & 96.2 & 3.5 & 5.9 & 6.6 \\
\hline is & 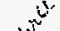 & 150 & $52 \%$ & 26 & $24 \%$ & 635 & 725 & 350 & 2750 & 97.7 & 98.2 & 98.1 & 97.8 & 2.1 & 5.5 & 7.6 \\
\hline 100 & $x^{N}$ & 150 & $52 \%$ & 26 & $24 \%$ & 725 & 825 & 450 & 2850 & 97.7 & 97.9 & 97.6 & 97.5 & 2.7 & 5.7 & 7.3 \\
\hline 167 & & 150 & $62 \%$ & 30 & 34 & 1200 & 1350 & 750 & 3250 & 97.8 & 98.3 & 98.3 & 98.0 & 1.7 & 5.1 & 6.8 \\
\hline 15 & or.3 & 150 & 25 & $20 \%$ & $14 \frac{1}{6}$ & 152 & 172 & 150 & 875 & 95,0 & 95.5 & 95.3 & 94.5 & 4.8 & 5.0 & 5.2 \\
\hline 30 & & 150 & $30 \%$ & $20 \%$ & $14 \% / 6$ & 230 & 300 & 200 & 1600 & 96.3 & 96.5 & 95.9 & 95.0 & 4.7 & 5.6 & 5.6 \\
\hline 45 & & 150 & $30 \%$ & $20 \%$ & $14 \%$ & 310 & 370 & 300 & 1900 & _96.5 & 96.9 & 96.5 & 96.1 & 3.7 & 4.5 & 4.5 \\
\hline 75 & & 150 & $37 \%$ & $261 / 8$ & $191 / 6$ & 480 & 550 & 400 & 3000 & 97.0 & 97.2 & \begin{tabular}{|l|}
96.8 \\
\end{tabular} & 96.1 & 3.6 & 4.9 & 4.9 \\
\hline 112.5 & & 150 & $37 \%$ & $261 / 8$ & $191 / 8$ & 600 & 675 & 500 & 4900 & 97.3 & 97.2 & \begin{tabular}{|l|}
96.6 \\
\end{tabular} & 95.8 & 3.9 & 5.8 & 5.9 \\
\hline 150 & & 150 & $461 / 2$ & 26 & $203 / 16$ & 760 & 850 & 600 & 6700 & 97.4 & 97.2 & \begin{tabular}{|l|}
96.5 \\
\end{tabular} & 95.7 & 3.8 & 5.7 & 6.2 \\
\hline 225 & & 150 & 56 & $31 / 4$ & $241 / 4$ & 1100 & 1200 & 700 & 8600 & 97.9 & 97.7 & 97.0 & 96.3 & 3.7 & 6.0 & 6.4 \\
\hline 300 & & 150 & 56 & $31 / 4$ & $241 / 4$ & 1300 & 1750 & 800 & 10200 & 98.2 & 97.9 & \begin{tabular}{|l|}
97.4 \\
\end{tabular} & \begin{tabular}{|l|}
97,6 \\
\end{tabular} & 3.4 & 6.3 & 7.1 \\
\hline 500 & & 150 & 75 & $441 / 2$ & 36 & 2400 & 3100 & 1700 & 9000 & 98.4 & 98.7 & \begin{tabular}{|l|}
98.6 \\
\end{tabular} & 98.4 & 1.5 & 4.2 & 5.5 \\
\hline 750 & & 150 & 75 & $44 \frac{1}{2}$ & 36 & 2900 & 3600 & 2200 & 11700 & 98.4 & 98.7 & \begin{tabular}{|l}
98.7 \\
\end{tabular} & \begin{tabular}{|c|}
98.5 \\
\end{tabular} & 1.5 & 4.7 & 6.3 \\
\hline 1000 & & 150 & 75 & 47 & 41 & 4000 & - & 2800 & 13600 & 98.6 & 98.9 & \begin{tabular}{|l}
98.8 \\
\end{tabular} & 98.6 & 1.2 & 4.7 & 6.5 \\
\hline 15 & & 115 & 25 & $20 \%$ & $14 \%$ & 152 & 172 & 150 & 700 & 95.3 & 96.3 & 96.1 & 95.6 & 3.8 & 5.1 & 5.2 \\
\hline 30 & & 115 & $30 \%$ & $20 \%$ & $14 \%$ & 230 & 300 & 200 & 1500 & 96.4 & 96.6 & \begin{tabular}{|l|}
96.1 \\
\end{tabular} & 95.3 & 4.3 & 4.5 & 5.3 \\
\hline 45 & & 115 & $30 \%$ & $20 \%$ & $14 \%$ & 310 & 370 & 300 & 1700 & 96.7 & 97.2 & 96.9 & 96.4 & \begin{tabular}{|l}
3.1 \\
\end{tabular} & 3.7 & 3.7 \\
\hline 75 & $\because$ & 115 & $37^{7 / 8}$ & $26 \%$ & $19 \%$ & 480 & 550 & 400 & 2300 & 97.3 & 97.7 & 97.5 & 97.0 & 2.6 & 4.0 & 4.6 \\
\hline 112.5 & & 115 & $37 \%$ & $26 / / 8$ & $19 / 6$ & 600 & 675 & 500 & 3100 & 97.7 & 98.0 & 97.7 & \begin{tabular}{|l}
97.3 \\
\end{tabular} & 2.5 & 5.5 & 6.5 \\
\hline 150 & & 115 & $461 / 2$ & 26 & $20 \% / 16$ & 760 & $850^{\circ}$ & 600 & 5900 & 97.8 & 97.9 & \begin{tabular}{|l}
97.5 \\
\end{tabular} & \begin{tabular}{|l}
97.1 \\
\end{tabular} & 3.8 & 5.9 & 6.2 \\
\hline 225 & & 115 & 56 & $311 / 4$ & $241 / 4$ & 1100 & 1200 & 700 & 6000 & 98.2 & \begin{tabular}{|l}
98.2 \\
\end{tabular} & 97.9 & 97.4 & 25, & 5.7 & 7.2 \\
\hline 300 & & 115 & 56 & $31 / 4$ & $241 / 4$ & 1300 & 1750 & 800 & 6600 & 98.4 & 98.5 & 98.2 & 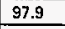 & 2.1 & 5.0 & 6.3 \\
\hline 500 & & 115 & 75 & $44 \frac{1}{2}$ & 36 & 2400 & 3100 & 1700 & 6800 & 98.4 & \begin{tabular}{|l|}
98.8 \\
\end{tabular} & 98.8 & 98.7 & 1.2 & 4.1 & 5.5 \\
\hline 15 & & 80 & $30 \%$ & $20 \%$ & $14 \%$ & 230 & 300 & 200 & 500 & 94.5 & 96.4 & 96.8 & 96.8 & 2.0 & 2.2 & 2.3 \\
\hline 30 & & 80 & $30 \%$ & $20 \% / 8$ & $14 / 8$ & 310 & 370 & 300 & 975 & 95.5 & 96.8 & 97.0 & 96.8 & 2.3 & 2.9 & 2.9 \\
\hline 45 & & 80 & $37 / 8$ & $26 \% / 8$ & $19 \%$ & 480 & 550 & 300 & 1100 & 97.0 & \begin{tabular}{|l}
97.8 \\
\end{tabular} & 97.8 & \begin{tabular}{|l|l}
97.6 \\
\end{tabular} & $\begin{array}{l}1.8 \\
\end{array}$ & 2.8 & 2.9 \\
\hline 75 & & 80 & $37 / 8$ & $26 \%$ & $191 / 6$ & 600 & 675 & 400 & 1950 & 97.5 & 97.9 & 97.8 & \begin{tabular}{|l|l}
97.4 \\
\end{tabular} & 2.2 & 3.5 & 3.7 \\
\hline 112.5 & & 80 & $46 \% / 2$ & 26 & $203 / 16$ & 750 & 850 & 600 & 3400 & 97.3 & \begin{tabular}{|c|}
97.7 \\
\end{tabular} & 97.4 & 97.0 & \begin{tabular}{|l}
2.6 \\
\end{tabular} & 4.1 & 4.3 \\
\hline 150 & & 80 & 56 & $31 \frac{1}{4}$ & $24 \% / 4$ & 1100 & 1200 & 700 & 3250 & 97.8 & 98.2 & 98.1 & 97.9 & 1.8 & 3.6 & 4.1 \\
\hline 225 & & 80 & 56 & $31 / 4$ & $241 / 4$ & 1300 & 1750 & 800 & 4000 & 98.2 & 98.6 & 98.5 & \begin{tabular}{|l}
98.2 \\
\end{tabular} & 1.6 & 4.2 & 5.3 \\
\hline 300 & & 80 & 75 & $441 / 2$ & 36 & 2400 & 3100 & 1700 & 4300 & 97.6 & 98.4 & 98.6 & 98.6 & 1.1 & 2.7 & 4.1 \\
\hline 500 & & 80 & 75 & $441 / 2$ & 36 & 2900 & 3600 & 2000 & 5500 & 98.9 & 98.9 & 98.8 & 98.2 & 1.2 & 4.0 & 4.5 \\
\hline
\end{tabular}




\section{Selection Guide}

HNF-2488, Rev. 0

-ACHMENT: D

Page C-25

GE: $D-1$

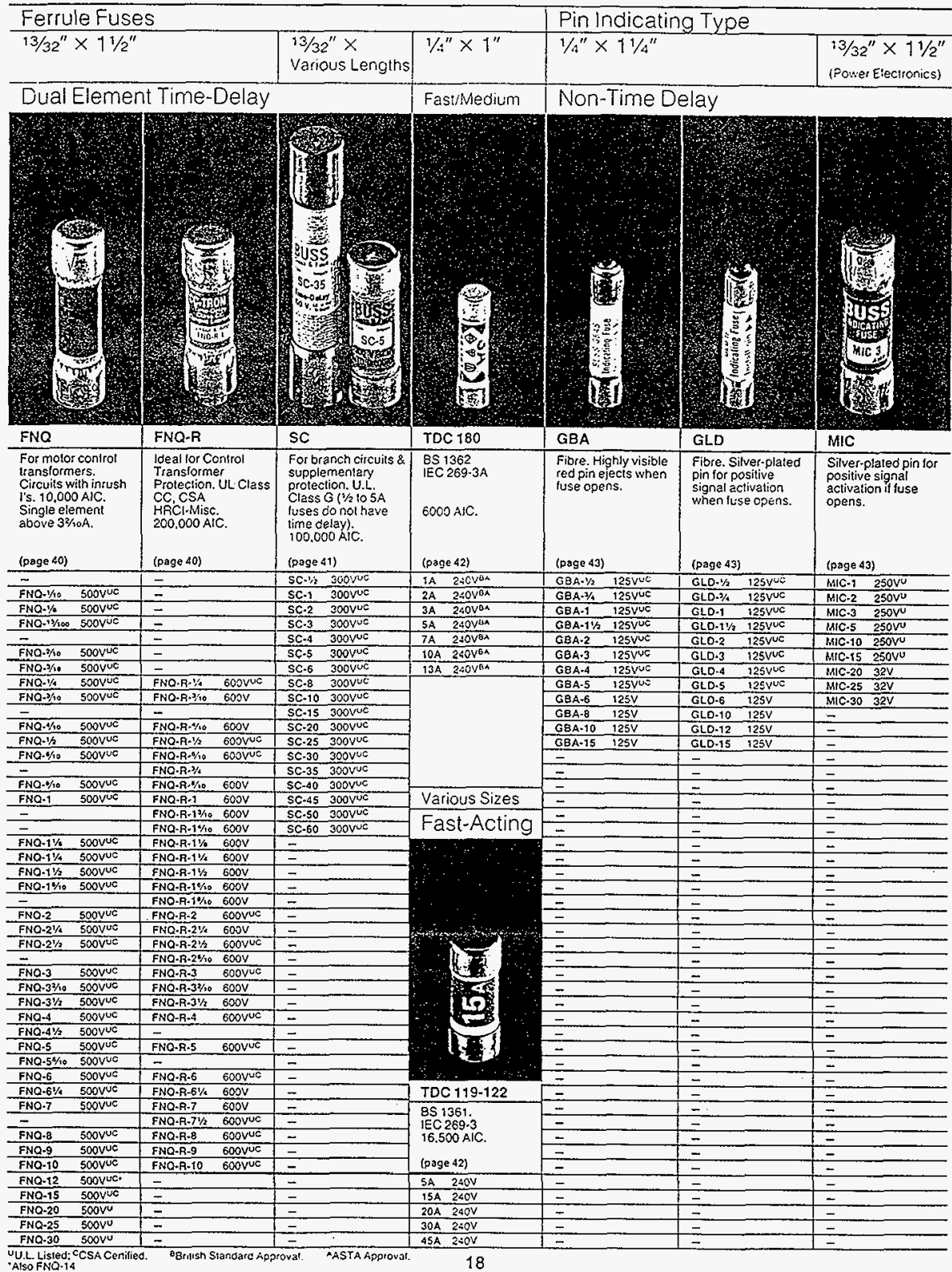




\section{Type FNQ}

$13 / 32^{\prime \prime} \times 1 \frac{112 "}{2}(10.3 \mathrm{~mm} \times 38.1 \mathrm{~mm})$

Time-Delay

Fibre. For motor control transformers and other circuits with inrush currents. Interrupting rating-10,000AIC. Mount in Buss fuseholders, fuseblocks, and clips. Shipping weight per 100-1.5 lbs. (680g). U.L. File E19180; Guide. JDYX. CSA File 53787; Class 1422-01.

\begin{tabular}{|c|c|c|c|c|c|c|c|}
\hline 500 Volls & \multirow{11}{*}{$\begin{array}{l}\text { U.L. } \\
\text { Lisied } \\
\& \text { CSA }\end{array}$} & 500 velis & & 500 Voits & & 500 Volls & \\
\hline FNO.1/10 & & INO 5.10 & \multirow{10}{*}{$\begin{array}{l}\text { U.L. } \\
\text { Lisled } \\
\text { S CSA }\end{array}$} & FNO $3 \% 10$ & \multirow{10}{*}{$\begin{array}{l}\text { UL. } \\
\text { Lisied } \\
\text { \& CSA }\end{array}$} & \&NO 9 & \multirow{4}{*}{$\begin{array}{l}\text { U1. } \\
\text { Listed } \\
\text { \& CSA }\end{array}$} \\
\hline $\mathrm{NO} \cdot \mathrm{L}$ & & FNO.1 & & FNO $0.3 \%$ & & FNO-10 & \\
\hline$\overline{1 \mathrm{NO}+\mathrm{V}_{1(1)}}$ & & FINO.1/s & & FNO.4 & & FNO.12" & \\
\hline TNO. $2 / 10$ & & FNO-11/4 & & FNO 41/2 & & HO-15 & \\
\hline FNQ.3/16 & & FNO.11/2 & & FNO.5 & & FNO-20 & \multirow{6}{*}{$\begin{array}{l}\text { UL. } \\
\text { Lisieo }\end{array}$} \\
\hline FNO.1/4 & & FNO.19610 & & FNO 5 Yrio & & FNO-25 & \\
\hline FNO $\% / 10$ & & FNO-2 & & FNO.6 & & FNO-30 & \\
\hline$F N O .4 / 10$ & & INO. $2^{1 / 4}$ & & FNO $61 / 4$ & & - & \\
\hline $1 N O \cdot 1 / 2$ & & FNO-21/2 & & FNO.? & & $=$ & \\
\hline FNO.6/10 & & FNO 3 & & FNO 8 & & - & \\
\hline
\end{tabular}

Also FNO-14

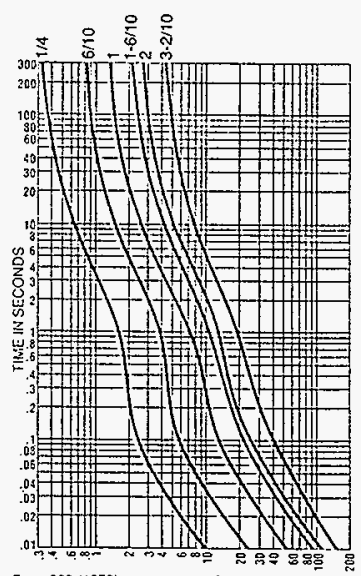

Form 220 (1973) CURRENT IN AMPEHES

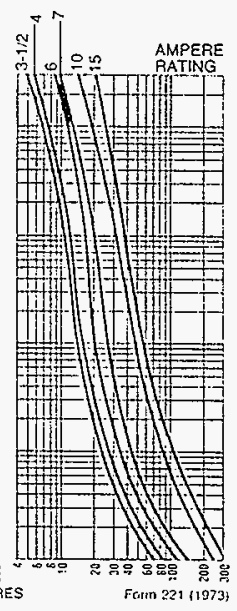

U.L. File E19180; CSA File 53787
Type FNQ-R

$13 / 32^{\prime \prime} \times 11 / 2^{\prime \prime}(10.3 \mathrm{~mm} \times 38.1 \mathrm{~mm})$

Time-Delay

The Bussmann CC-Tron "F (FNQ-R) was developed to meet a specific need in the industry-control circuit transformer protection. Its voltage rating, inter rupting rating, time-delay, high degree of current limitation, and rejection feature uniquely qualify it for this task. Mount in Buss Class CC blocks page __ UL Listed File E4273 Branch Circuit Fuse; Class CC; CSA File 53787 -HRC-MISC

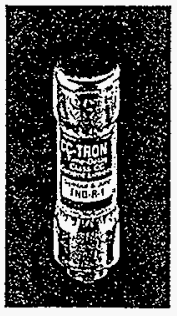

Electrical Ratings (Catalog Symbol and Amperes) $200 \mathrm{~K}$ AIC

\begin{tabular}{|c|c|c|c|}
\hline 600 Volts & 600 volss & 600 Volts & 600 Volts \\
\hline FNO-R-1,4 & FNC.R+15io & FNO-R.1\%:0 & FNO.R.31/2 \\
\hline FNO.R.ito & FNQ.8.1+10 & FNO.R.2. & FNO-R.4UE \\
\hline FNO Rn-3 & FNO 0.1 . & FiNO $0.8 .2^{1 / 4}$ & FiNo. $\bar{R} \cdot 5^{\mathrm{WC}}$ \\
\hline FNO-R.126C & FNO.A.1\% & FNO-R-21/2 uc & ENORR.G \\
\hline FlNO.R.थ. WO & FNOQR+1\% & FNO-R-2:10 & FNO-R-6\% \\
\hline FNO.R+m & FNO.R.14 & FNO-P.-3 & FNO-R-7 \\
\hline ENO-R-1 & FNOO-R- $1 \% / 10$ & FNO. $\mathrm{A} \cdot 3 \div 0$ & FNO-R.71/2 ${ }^{\circ C}$ \\
\hline
\end{tabular}

U.L. Listed: ${ }^{\mathrm{C} C S A}$ Certified

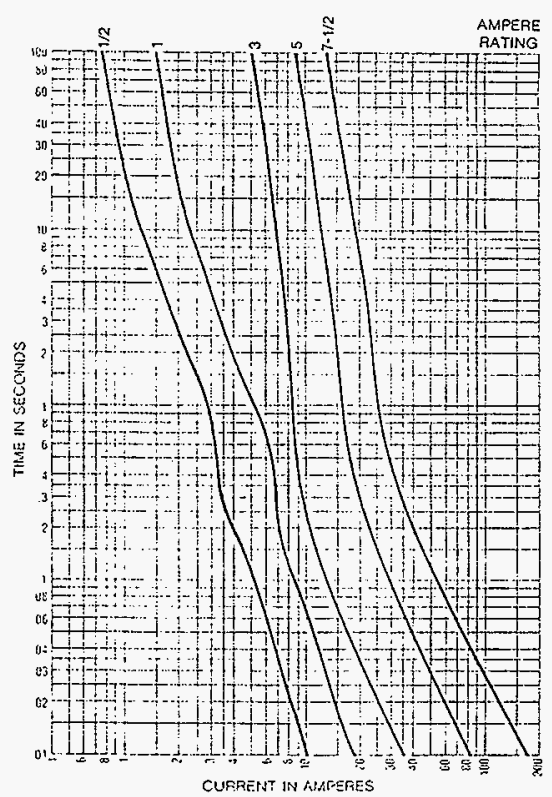

HNF-2488, Rev. 0

Page C-26 
Calc: W320-31-022

Attachment: D

Page: $0-3$

\section{TELEPHONE CONFERENCE MEMORANDUM}

company:ICF Kaiser Hanford Company

[] INCOMING

[X] outgoing

WITH: Dave Burnhard

WITH:

Copies to:

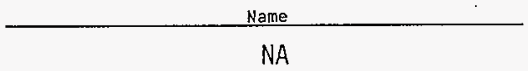

NA
Address: P.0. Box 888, Richland, WA 99352
DATE: $10 / 6 / 94$
TIME: $9.00 \mathrm{AM}$
of: Bussmann Fuse Co.
PHONE: (314) 527-1224
PHONE:
OF:

\section{Prove:}

Address

NA

Moe Khorsandian Engineering Services Department
W-320 Project, W320-31-022 Calculation
(509) $373-2331$

Telephone \#

Summary of Conference

Per telephone conversation with Mr. Dave Burnhard, the resistance ranges of FNQ type, time delay, dual element fuses are as follows:

FNQ-1 0.0456 to $0.7 \Omega$

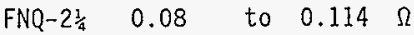

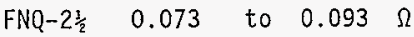

FNQ-3 0.0395 to $0.056 \Omega$

HNF-2488, Rev. 0

Page C-27 


\section{TECHNICAL DATA}

- Standards and approvals:

UL $\ldots \ldots \ldots \ldots \ldots \ldots \ldots \ldots \ldots \ldots \ldots \ldots \ldots$

I.E.C........................... 947-5-1, BS4794

CSA ......................... C22-2 No. 14

- Ingress Protection (IP ratings to I.E.C. $144-B S 5420)$ :

All operators $0 \ldots \ldots \ldots$ UL Listed (NEMA) Type 1, 2,

$3,3 R, 4,4 X, 12,13$ when mounted in enclosure rated for those same applications Pushbuttons when fitted with a rubber boot ........ IP66 Enclosures ......................... IP65

- Frequency of operation - maximum:

All pushbutions................ $6000 \mathrm{ops} / \mathrm{hr}$. Key and lever selector switches......... 3000 ops $/ \mathrm{hr}$. Auto-latch devices ............... $1200 \mathrm{ops} / \mathrm{hr}$.

- Mechanical life:

Pushbuttons ............... $10 \times 10^{6}$ operations Contact blocks ................ $10 \times 10^{6}$ operations Prestest units ............... $10 \times 10^{6}$ operations Lever and key selector sws. . . . . . $0.25 \times 10^{6}$ operations Twist to release pushbuttons ..... $0.3 \times 10^{6}$ operations

- Climatic conditions:

Operating $\ldots \ldots \ldots \ldots \ldots$ maximum $60^{\circ} \mathrm{C}$ at $95 \% \mathrm{RH}$, Temperature $-17^{\circ} \mathrm{C}$ to $66^{\circ} \mathrm{C}$, altitude 2000 meters

Storage ............. maximum $60^{\circ} \mathrm{C}$ at $95 \% \mathrm{RH}$, Temperature $-40^{\circ} \mathrm{C}$ to $80^{\circ} \mathrm{C}$

- Shock resistance:

Duration ................... $20 \mathrm{~ms} \geq 5 \mathrm{~g}$

- Electrical Ratings:

Insulation............... Vi $=660 \mathrm{~V}$ ac or dc Thermal. ................ ith $=10$ amperes Short circuit (I.E.C. 947-5-1)

........... 1000 A with a $6 \mathrm{~A}$ (NIT) fuse (to BS88)

NEMA, UL rating.................... A600, P600

Ac load life duty cycle 1200 operations/hour

$10 \mathrm{~A} \ldots \ldots \ldots \ldots \ldots, 110 \mathrm{~V}$ pf $0.4-1 \times 10^{6}$ operations $5 \mathrm{~A} \ldots \ldots \ldots \ldots \ldots 250 \mathrm{~V}$ pf $0.4-1 \times 10^{6}$ operations $2 \mathrm{~A} \ldots \ldots \ldots \ldots \ldots \ldots$. $660 \mathrm{~V}$ pf $0.4-1 \times 10^{6}$ operations

- Switching capacity:

AC15 rated make/break ( $11 \times$ le at $1.1 \times$ Ue $)$

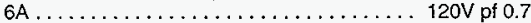

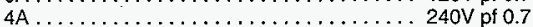

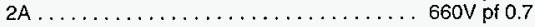

DC13 rated make/break $(1.1 \times$ le at $1.1 \times$ Ue $)$

$1.0 \mathrm{~A} \ldots \ldots \ldots \ldots \ldots \ldots 125 \mathrm{~V} \cup \mathrm{K} \geq 0.95$ at $300 \mathrm{~ms}$

$0.55 \mathrm{~A} \ldots \ldots \ldots \ldots \ldots .250 \mathrm{~V} L \mathrm{R} \geq 0.95$ at $300 \mathrm{mS}$

$0.2 A \ldots \ldots \ldots \ldots \ldots 600 \vee L R \geq 0.95$ at $300 \mathrm{~ms}$

$10 \mathrm{~A} \ldots \ldots \ldots \ldots \ldots \ldots \ldots \ldots .110 \mathrm{~V}$ pure resistive

- Light units:

Transformers. . ......... will withstand short circuit for

Bulbs - average life:

1 hour per I.E.C. 947-5-1

Transformer type ................ 20,000 hrs.

Resistor/direct voltage type . . . . . . . . 2500 hrs.

minimum@ rated V
- Low voltage switching

Conical shaped points or "reliability nibs" improve performance in dry circuit, corrosive, fine dust and other contaminated atmospheres. Under normal environmental conditions, the minimum operational voltage is $5 \mathrm{~V}$ and the minimum operational current is $1 \mathrm{~mA}$, ac/dc.

\section{- Contact operation}

Slow make and break. All normally closed contacts have positive opening operation, i.e., normally closed contacts are forced open in the event of contact weld or spring breakage.

- Terminal marking

NC - NO on the contact block to meet the NEMA require. ments. Dual marking system $1-2$ for normally closed, $3-4$ for normally open to meet BS5472 (Cenelec EN50 005).

- Terminal clamps

Terminals are saddle clamp type for $1 \times 22$ AWG $[0.5 \mathrm{sq} . \mathrm{mm}]$ to $2 \times 12$ AWG $[3.0$ sq. $\mathrm{mm}$ ] conductors.

- Panel thickness

Maximum. . . . . . $0.25 \mathrm{in}[8 \mathrm{~mm}]$ including legend plate Minimum ................... 0.06 in $[1.6 \mathrm{~mm}$ Maximum can be increased to 0.375 in $[15.9 \mathrm{~mm}]$ using optional retaining nut. See Page $M-101$ or catalog numbers.

- Mounting matrix

\begin{tabular}{l|c|c|c|c}
\hline \multirow{2}{*}{$\begin{array}{c}\text { Legend } \\
\text { Plate }\end{array}$} & \multicolumn{5}{|c}{ Dimensions in Inches [mm] } \\
\cline { 2 - 5 } & A . & B & C & D \\
\hline Small & $1.63[41.3]$ & $2.25[57.2]$ & $1.63[41.3]$ & $2.25[57.2]$ \\
Medium & $1.63[41.3]$ & $2.25[57.2]$ & $1.87[47.6]$ & $2.25[57.2]$ \\
Large & $2.13[54.0]$ & $2.31[58.7]$ & $2.3[58.7]$ & $2.25[57.2]$ \\
\hline
\end{tabular}

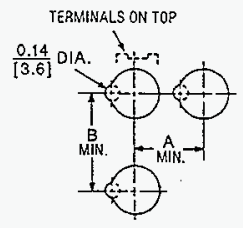

Horizontal Mounting

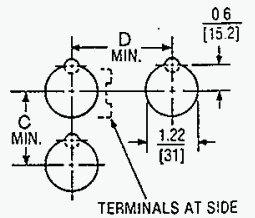

Vertical Mounting
Horizontal mounting means terminals are located top and bottom of contact block. Vertical mounting means terminals are left and right of contact block. This allows close spacing of adjacent operators with easy access to terminals.

NOTE: Locating nib hole or notch is $.14 "[3.6 \mathrm{~mm}] \# 29$ drill. Alteriate to drilling mounting hole, use Greenlee Tool Co., punch No. 730-S to punch the hole and follow with punch No. $730-K$ to cut the notch.

(1) Use NEMA 4X 10250T operators where

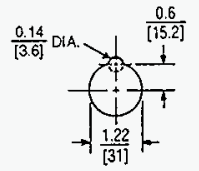
exposed to Ultra Violet lighi, see Pages M-53 - M-84. 
FUSHBU I UNS AND INDICAIIVG LIGHIS $30.5 \mathrm{~mm}$ Heavy Duty Oiltight Assembled Devices

$$
\text { ATTACHIMENT:E }
$$

- INDICATING LIGHT W/ LENS ASSEMBLED-UL (NEMA) Type 4, 4X, 13 Transformer Type, $120 \mathrm{~V}$ ac 50 or $60 \mathrm{~Hz}$

PresTest Indicating Light - This device incorporates a PresTest feature whereby depressing the lens disconnects the light from the source being monitored and connects the lamp to a continuously energized circuit for immediate test for a faulty lamp.
Master Test Indicating L Light - Available with solid state isolation or with transformer/relay type isolation. these dual input light units can be energized either by a monitored signal or by an independent test signal. This permits testing the lamps on a group of Master Test type indicating lights from a single pushbutton or other switch. See wiring diagram below.

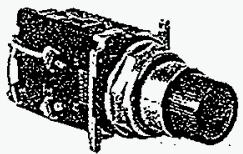

PresTest Indicating Light Cat, No. 10250774NA

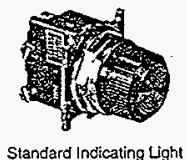
Standard Indicating $\mathrm{Ught}$
Cat. No. 10250T34R

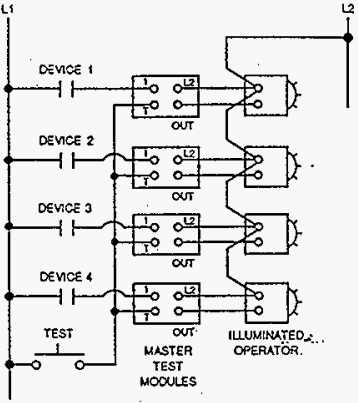

\begin{tabular}{|c|c|c|c|c|c|c|c|c|c|c|c|c|}
\hline \multirow{4}{*}{ Volts } & \multirow{4}{*}{$\begin{array}{l}\text { Lamp } \\
\text { Number }\end{array}$} & \multirow{4}{*}{$\begin{array}{l}\text { Lens } \\
\text { Cotor }\end{array}$} & STANDAF & UNIT & \multicolumn{4}{|c|}{ PRES-TEST } & \multirow{2}{*}{\multicolumn{4}{|c|}{$\begin{array}{c}\text { MASTER TEST } 2 \\
\text { Plastic Lens }\end{array}$}} \\
\hline & & & \multirow{2}{*}{\multicolumn{2}{|c|}{ Plastic Leñs }} & \multirow{3}{*}{$\begin{array}{l}\text { Plastic } \\
\text { Lens O }\end{array}$} & \multirow{3}{*}{ Price } & \multirow{3}{*}{$\begin{array}{c}\begin{array}{c}\text { Glass } \\
\text { Lens } \mathbf{0}\end{array} \\
\text { Cat. No. }\end{array}$} & \multirow{3}{*}{ Price } & & & & \\
\hline & & & & & & & & & \multicolumn{2}{|c|}{$\begin{array}{c}\text { Transformer Type } \\
\text { with Relay o }\end{array}$} & \multicolumn{2}{|c|}{$\begin{array}{c}\text { Solid State Type } \\
\text { (Uses a 120M8 Lamp) }\end{array}$} \\
\hline & & & Cat. No. $\mathbf{0}$ & Price & & & & & Cat:Not? & Price & Sicta & Price \\
\hline 120 & $\begin{array}{c}\text { y755 } \\
\text { (Will Ailso } \\
\text { Accept } \\
\$ 44)\end{array}$ & $\begin{array}{l}\text { Red } \\
\text { Green } \\
\text { Amber } \\
\text { Yellow } \\
\text { Blue } \\
\text { Clear } \\
\text { White }\end{array}$ & $\begin{array}{c}10250 \mathrm{~T} \\
34 \mathrm{R} \\
\because 34 \mathrm{G} \\
\therefore 34 \mathrm{~A} \\
\therefore 34 \mathrm{Y} \\
34 \mathrm{~B} \\
\\
\therefore 34 \mathrm{C} \\
34 \mathrm{~W}\end{array}$ & & $\begin{array}{c}10250 \mathrm{~T} \\
74 \mathrm{NR} \\
774 \mathrm{NG} \\
74 \mathrm{NA} \\
: 74 \mathrm{NY}: \\
74 \mathrm{NB} \\
\because \\
74 \mathrm{NC} \\
74 \mathrm{NW}:\end{array}$ & & \begin{tabular}{c}
$10250 \mathrm{~T}$ \\
$37 \mathrm{NR}$ \\
$37 \mathrm{NG}$ \\
$37 \mathrm{NA}$ \\
\hdashline- \\
$37 \mathrm{NB}$ \\
\\
$37 \mathrm{NC}$ \\
$37 \mathrm{NW}$
\end{tabular} & & 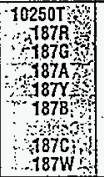 & - & 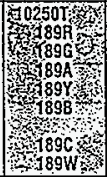 & \\
\hline
\end{tabular}

Master Test Wiring Diagram

0 For flashing lamp add leter ${ }^{*} F$ to listed catalog number and add $\$ 6.00$ to price. Example: 10250T34RF, Price $\$ 70.20$.

(2) The Transformer/Relay type puts out slightly more light becauso it operates on full wave.

\section{POTENTIOMETER WITH KNOB AND STANDARD}

DIAL PLATE - Linear Type $\pm 10 \%$

Vertical or Horizontal One Hole Mounting

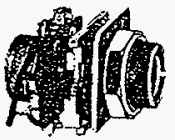

\begin{tabular}{|c|c|c|}
\hline \multirow[t]{2}{*}{$\begin{array}{c}\text { Potent- } \\
\text { iometer } \\
\text { Ohms }\end{array}$} & \multicolumn{2}{|c|}{$\begin{array}{l}2 \text { Watt (50 V Max.) } \\
\text { Single Potentiometer } \\
\text { NEMA 4, } 13 \\
\text { कO Standard Dial Plate }\end{array}$} \\
\hline & GatiNo & Price \\
\hline $\begin{array}{r}1000 \\
2500 \\
5000 \\
10000 \\
25000 \\
50000\end{array}$ & 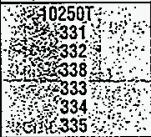 & \\
\hline Operator Only 9 & $40,330,4$ & 84. \\
\hline
\end{tabular}

With Standard Dial Plate
3 Large cial plate with space for legend is avaiable at no charge. To order, add sufix 36 to catalog number. Example: 10250 T33136. To order separately, see footnote $\Theta$ below.

(4) Large dial plate has space at too for 15 letters $3 / 32$ inch high. For custom stamped legend plates. order tegend plate as separate item 10250TR30 and specify stamping - Price \$6. (without stamping - \$1.80).

$\theta$ For use with commercially purchased potentiometers having shaft dimensions per dimension drawing on Page M-81.

DIMENSIONS, Pages M-82 - M-84
HNF-2488, Rev. 0

Page C-29 


\section{ORDERING COMPLETE UNASSEMBLED OPERATORS USING SINGLE}

\section{COMPOSITE CATALOG NUMBER}

For convenience - when ordering from the components listings - the individual component catalog numbers may be combined into a single catalog number. Individual components will be packed in a single box labeled with the combined identification number.

\section{Example:}

Component numbers for an illuminated pushbutton with red lens, a NO-NC contact block, a NO contact block and "START" legend plate.

$10250 T 411$ (illuminated pushbutton - Page $M-63$ )

10250TC21 (red lens - Page M-63)

$10250 T 1$ (NO-NC contact block - Page M-62)

10250T53 (NO contact block - Page M-62)

10250TS33 ("START' legend plate - Page M-76)
Combined into a single catalog number (Any component may be omitted by merely collapsing the number to eliminate the space).

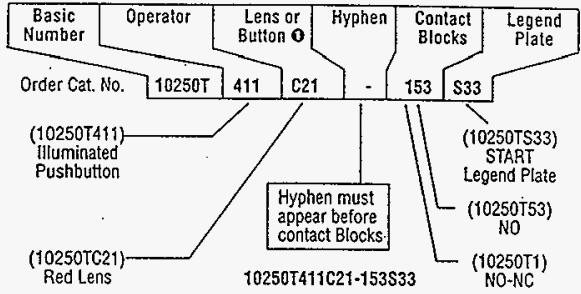

0 When not included with operator.

ORDERING EXAMPLES:

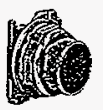

Operator $10250 T 101$

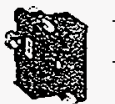

Contact Block
10250T1

(Page $M-62$ )

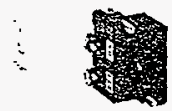

Contact Block $10250 T 51$

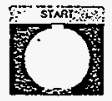

Legend Plate

$10250 \mathrm{TS} 33$

(Pages $M-76-M \cdot 77$ )
For complete $10250 \mathrm{~T}$ operators using single composite catalog number (Example: 10250T101-151533), See Instruction Above.

PUSHBUTTON OPERATORS - Vertical or Horizontal Mounting - UL (NEMA) Type 4, 4X and 13

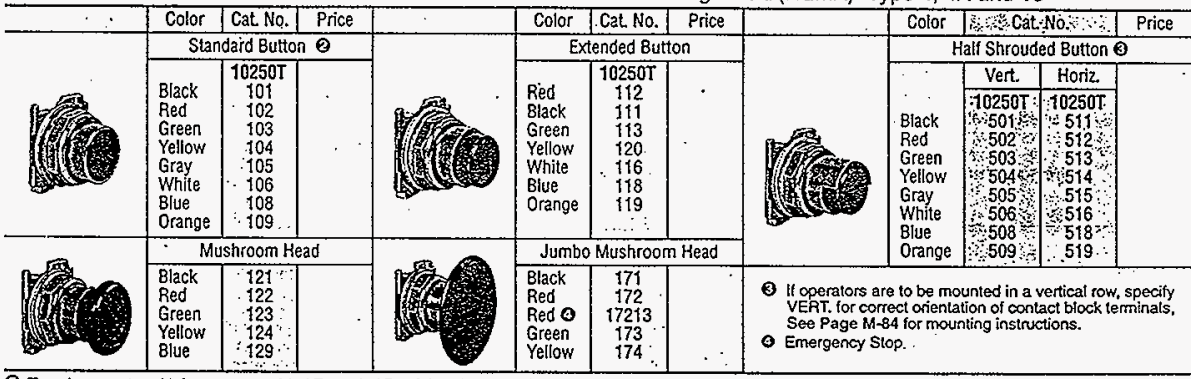

(2) To order operalor with factory assembled Extended Retaining Nut, 10250TA12, for thick panel applications, add suffix letter "E"' to listed cat. no. Example: 10250T 101E. MAINTAINED PUSHBUTTON OPERATOR

\begin{tabular}{|c|c|c|}
\hline$\because \because \quad \because$ & Description & 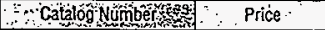 \\
\hline th & $\begin{array}{l}\text { Minimum hole centers } 1.62 \text {, maximum } 2.50^{*} . \text { Mounts in } \\
\text { extra deep enclosures only. } \\
\text { Black flush and green flush } \ldots \ldots \ldots \ldots \ldots \ldots \ldots \ldots \ldots \ldots \\
\text { Black flush and long red. } \ldots \ldots \ldots \ldots \ldots \ldots \ldots \ldots \ldots \ldots \\
\text { Black flush and red mushroom head } \ldots \ldots \ldots \ldots \ldots \ldots \\
\text { Black flush and lock-down red mushroom head }\end{array}$ & 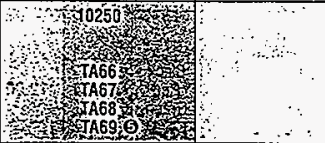 \\
\hline 得 & 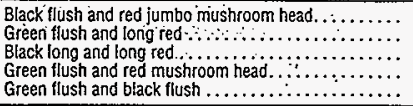 & 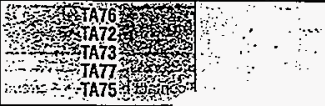 \\
\hline
\end{tabular}

O NC contacts must be mounted behind lock-down mushroom head operator to ensure lockout.

DISCOUNT SCHEDULE 1CO-1

DIMENSIONS, Pages M-82 - M-84

July 1995
HNF-2488, Rev. 0

Page C-30 
CR104P Heavy-Duty Indicating Lights

600 Vots Maximum $\mathrm{AC} / \mathrm{DC}$

10 Amperes Continuous

Suitable for Use in NENA Type 1

$3,3 R, 4,4 X, 12$ and $13, A p p l i c a t i o n s(1)$

Units are supplied factory assembled when ordered

with lenses.

\begin{tabular}{|c|c|c|c|c|c|}
\hline $\begin{array}{l}\text { Operating } \\
\text { Votiage }\end{array}$ & $\begin{array}{l}\text { Color of } \\
\text { Lens }\end{array}$ & $\begin{array}{c}\text { Stanjard Un: } \\
\text { Calalog } \\
\text { Numbers } \\
\text { CRiotP }\end{array}$ & $\begin{array}{c}\text { Lst } \\
\text { Price, } \\
\text { GO-10P1 }\end{array}$ & 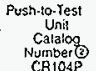 & $\begin{array}{l}\text { Ust } \\
\text { Prlce: } \\
\text { Go-10P1 }\end{array}$ \\
\hline
\end{tabular}

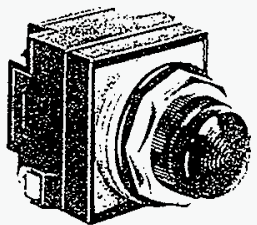

Standard indicating light

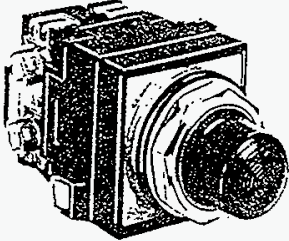

Push-to-Test Indicating light

Resistor Type

\begin{tabular}{|c|c|c|c|c|c|}
\hline \multirow[t]{2}{*}{ 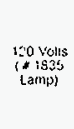 } & $\begin{array}{l}\text { Red } \\
\text { Gicen } \\
\text { Amber } \\
\text { Blus } \\
\text { Sunte } \\
\text { Yellow } \\
\text { Cleni }\end{array}$ & 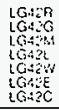 & $\begin{array}{r}\$ 52.20 \\
52.20 \\
52.20 \\
\$ 2.20 \\
52.20 \\
52.20 \\
52.20\end{array}$ & $\begin{array}{l}\mathrm{LT} 42 \mathrm{~A} \\
\mathrm{LT} 42 \mathrm{G} \\
\mathrm{LT}+2 \mathrm{H} \\
\mathrm{LT}+2 \mathrm{~L} \\
\mathrm{LT} 42 \mathrm{~W} \\
\mathrm{LT} 42 \mathrm{E} \\
\mathrm{LT} 42 \mathrm{C}\end{array}$ & $\begin{array}{r}\$ 70.20 \\
70.20 \\
70.20 \\
70.20 \\
70.20 \\
70.20 \\
70.20\end{array}$ \\
\hline & lesstens( & LG? & 48.00 & LTa2 & 66.00 \\
\hline \multirow[t]{2}{*}{ 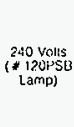 } & $\begin{array}{l}\text { Red } \\
\text { Green } \\
\text { fimber } \\
\text { Gitus } \\
\text { White } \\
\text { Yellow } \\
\text { Clear }\end{array}$ & 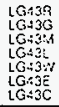 & $\begin{array}{l}52.20 \\
52.20 \\
52.20 \\
52.20 \\
52.20 \\
52.20 \\
52.20\end{array}$ & $\begin{array}{l}\text { LT43A } \\
\text { LT43G } \\
\text { L } 43 \mathrm{M} \\
\text { LT43L } \\
\text { LT43W } \\
\text { LT43E } \\
\text { LT43C }\end{array}$ & $\begin{array}{r}\quad 70.20 \\
70.20 \\
70.20 \\
70.20 \\
70.20 \\
70.20 \\
70.20\end{array}$ \\
\hline & Less tens@ & $1 G 43$ & 48.00 & LTA3 & 66.00 \\
\hline
\end{tabular}

\section{Standard and Push-to-Test Indicating Light} Units, Transformer Type

\begin{tabular}{|c|c|c|c|c|c|}
\hline $\begin{array}{l}\text { Operating } \\
\text { voltage }\end{array}$ & $\begin{array}{c}\text { Colot of } \\
\text { Lens }\end{array}$ & $\begin{array}{c}\text { Slandaro Unit } \\
\text { Calalog } \\
\text { Number(2) } \\
\text { CA104 }\end{array}$ & $\begin{array}{c}\text { Ust } \\
\text { Prlce. } \\
\text { Go-10PI }\end{array}$ & $\begin{array}{c}\text { Pusin-to.Test } \\
\text { Unit } \\
\text { Catatog } \\
\text { Number } \\
\text { CR104 }\end{array}$ & $\begin{array}{c}\text { Hst : } \\
\text { Prico, } \\
\text { Go-10Py }\end{array}$ \\
\hline
\end{tabular}

Transformer Type with 6-Volt Secondary,

No. 755 Lamp

\begin{tabular}{|c|c|c|c|c|c|}
\hline \multirow[t]{2}{*}{$\begin{array}{l}120 \text { Volls } \\
(60 / 50 \mathrm{~Hz})\end{array}$} & $\begin{array}{l}\text { Red } \\
\text { Green } \\
\text { Amber } \\
\text { Elue } \\
\text { While } \\
\text { Yellow } \\
\text { Cleat }\end{array}$ & $\begin{array}{l}\text { PLG32R } \\
\text { PLG32G } \\
\text { PLG32M } \\
\text { PLG322 } \\
\text { PLG32W } \\
\text { PLG32E } \\
\text { PLG32C }\end{array}$ & $\begin{array}{r}\$ 64.20 \\
64.20 \\
64.20 \\
64.20 \\
664.20 \\
\because 64.20 \\
64.20\end{array}$ & $\begin{array}{l}\text { PLT32R } \\
\text { PLT32C } \\
\text { PLI33M } \\
\text { PLT32L } \\
\text { PLT32W } \\
\text { PLY32E } \\
\text { PLT32C }\end{array}$ & $\begin{array}{r}\$ 82.20 \\
\therefore 82.20 \\
82.20 \\
\therefore 82.20 \\
1882.20 \\
882.20 \\
82.20 \\
8\end{array}$ \\
\hline & Less Lens(9) & $P L G 32$ & $: 60.00$ & PiT32 & $78.00^{\circ}$ \\
\hline \multirow[t]{2}{*}{$\begin{array}{l}240 \text { Volls } \\
(60 / 50 \mathrm{~Hz})\end{array}$} & $\begin{array}{l}\text { Fed } \\
\text { Green } \\
\text { Amber } \\
\text { Bfue } \\
\text { While } \\
\text { Yellow } \\
\text { Clear }\end{array}$ & $\begin{array}{l}\text { PLG33R } \\
\text { PLG33G } \\
\text { PLG33M } \\
\text { PLG33L } \\
\text { PLG33W } \\
\text { PLG33E } \\
\text { PLG33C }\end{array}$ & $\begin{array}{r}64.20 \\
64.20 \\
64.20 \\
64.20 \\
64.20 \\
64.20 \\
64.20\end{array}$ & $\begin{array}{l}\text { PLT33R } \\
\text { PLT33G } \\
\text { PLI33M } \\
\text { PLI33L } \\
\text { PLI33W } \\
\text { PLT33E } \\
\text { PLI33C }\end{array}$ & $\begin{array}{r}82.20 \\
\because 82.20 \\
82.20 \\
82.20 \\
\because 82.20 \\
\therefore 82.20 \\
8 \quad 82.20 \\
\end{array}$ \\
\hline & Less Lens(3) & PLG33 & 60.00 & PLT33 & 78.00 \\
\hline \multirow[t]{2}{*}{$\begin{array}{c}480 \text { Volis } \\
(60 / 50 \mathrm{~K})\end{array}$} & $\begin{array}{l}\text { Red } \\
\text { Green } \\
\text { Amber } \\
\text { Ence } \\
\text { White } \\
\text { Yellow } \\
\text { Clear }\end{array}$ & $\begin{array}{l}\text { PLG34R } \\
\text { PLG34G } \\
\text { PLG34M } \\
\text { PLG34L } \\
\text { PLG34W } \\
\text { PLG34E } \\
\text { PLG34C }\end{array}$ & 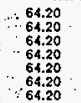 & $\begin{array}{l}\text { PLI34R } \\
\text { PLT34G } \\
\text { PLT T34M } \\
\text { PLT34L } \\
\text { PLT34W } \\
\text { PLT34E } \\
\text { PLY34C }\end{array}$ & $\begin{array}{r}82.20 \\
8220 \\
8220 \\
82.20 \\
82.20 \\
882.20 \\
8.82 .20\end{array}$ \\
\hline & Less Lens@ & PLGBA & 60.00 & PLT34 & 78.00 \\
\hline \multirow[t]{2}{*}{$\begin{array}{l}600 \text { Volls } \\
(60 / 50 \mathrm{~Hz})\end{array}$} & $\begin{array}{l}\text { Red } \\
\text { Green } \\
\text { Amber } \\
\text { Blue } \\
\text { While } \\
\text { Yellow } \\
\text { Clear }\end{array}$ & $\begin{array}{l}\text { PLG35R } \\
\text { PLG35G } \\
\text { PLG35M } \\
\text { PLG35L } \\
\text { PLG35W } \\
\text { PLG35E } \\
\text { PLG35C }\end{array}$ & $\begin{array}{r}\quad 64.20 \\
\therefore 64.20 \\
64.20 \\
64.20 \\
64.20 \\
\therefore \quad 64.20 \\
64.20\end{array}$ & 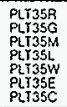 & $\begin{array}{l}82.20 \\
82.20 \\
82.20 \\
8220 \\
82.20 \\
82.20 \\
82.20\end{array}$ \\
\hline & Less Lens(3) & PLG35 & 60.00 & PLT35 & 78.00 \\
\hline
\end{tabular}

Notes: Catalog Number and price do not include nameolate. All nameplates must be ordered as a separale ilem from pages 7-26 and 7-27.

Resistor forms of standard and push-to-test indicating lights are available. Contact nearest GE Electrical Distribution \& Control sales office for proper selection and pricing.

Nameplate Selection Drilling Plan and

page $7 \cdot 28$

\section{Standard and Push-to-Test Indicating Light} Units, Full Voltage

\begin{tabular}{|c|c|c|c|c|c|}
\hline $\begin{array}{l}\text { Operating } \\
\text { Voliage }\end{array}$ & $\begin{array}{c}\text { Color of } \\
\text { Lens }\end{array}$ & $\begin{array}{c}\text { Slandard Unit } \\
\text { Calalon } \\
\text { Number(2) } \\
\text { Crio4 }\end{array}$ & $\begin{array}{c}\text { Ust } \\
\text { Prlce. } \\
\text { co-topi }\end{array}$ & $\begin{array}{c}\text { Pusn-10-Test } \\
\text { Unit } \\
\text { Calalog } \\
\text { Number(3) } \\
\text { CR104 }\end{array}$ & 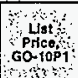 \\
\hline
\end{tabular}

Full Voltage Type

\begin{tabular}{|c|c|c|c|c|c|}
\hline \multirow[t]{2}{*}{$\begin{array}{c}6 \text { Vott } \\
(* 755 \text { Lamp) }\end{array}$} & $\begin{array}{l}\text { Red } \\
\text { Green } \\
\text { Amber } \\
\text { Blue } \\
\text { While } \\
\text { Yellow } \\
\text { Clear }\end{array}$ & $\begin{array}{l}\text { PLG 16R } \\
\text { PLG160 } \\
\text { PLG16h } \\
\text { PLG16L } \\
\text { PLG16W } \\
\text { PLG } 169 \\
\text { PLG } 16 C\end{array}$ & $\begin{array}{r}552.20 \\
52.20 \\
\therefore 52.20 \\
\because 52.20 \\
52.20 \\
\because 52.20 \\
\because 52.20\end{array}$ & $\begin{array}{l}\text { PLT 16R } \\
\text { PLT 16G } \\
\text { PLT 16M } \\
\text { PLT 161 } \\
\text { PLT 16W } \\
\text { PLT 16E } \\
\text { PLT I6C }\end{array}$ & $\begin{array}{r}570.20 \\
70.20 \\
70.20 \\
70.20 \\
70.20 \\
70.20 \\
70.20\end{array}$ \\
\hline & Less Lens(2) & PLG16 & .48 .00 & PLI: 6 & $\therefore 66.00$ \\
\hline \multirow[t]{2}{*}{$\begin{array}{c}12 \text { Volls@ } \\
\text { ( } 756 \text { Lamp) }\end{array}$} & $\begin{array}{l}\text { Red } \\
\text { Green } \\
\text { Ambes } \\
\text { Glue } \\
\text { While } \\
\text { Yeilow } \\
\text { Clear }\end{array}$ & $\begin{array}{l}\text { PLG178 } \\
\text { PLG17G } \\
\text { PLG17M } \\
\text { PLG17L } \\
\text { PLG17W } \\
\text { PLG17E } \\
\text { PLG17C }\end{array}$ & $\begin{array}{r}\because 52.20 \\
52.20 \\
\therefore 52.20 \\
52.20 \\
52.20 \\
52.20 \\
52.20\end{array}$ & $\begin{array}{l}\text { PLT 178 } \\
\text { PLT 17G } \\
\text { PLT 17M } \\
\text { PLT 17L } \\
\text { PLT 17W } \\
\text { PLT 17E } \\
\text { PLT I7C }\end{array}$ & $\begin{array}{r}70.20 \\
70.20 \\
70.20 \\
70.20 \\
70.20 \\
70.20 \\
70.20\end{array}$ \\
\hline & Less Lens() & PLG17 & 48.00 & PLT17 & $\therefore 66.00$ \\
\hline \multirow[t]{2}{*}{$\begin{array}{l}\text { 24 Volts@ } \\
\text { (1819 Lamp) }\end{array}$} & $\begin{array}{l}\text { Red } \\
\text { Green } \\
\text { Amber } \\
\text { Blue } \\
\text { White } \\
\text { Yellow } \\
\text { Clear } \\
\end{array}$ & $\begin{array}{l}\text { PLG18R } \\
\text { PLG18G } \\
\text { PLG 181 } \\
\text { PLG 186 } \\
\text { PLG18W } \\
\text { PLG18E } \\
\text { PLG18C }\end{array}$ & $\begin{array}{r}52.20 \\
52.20 \\
52.20 \\
52.20 \\
\therefore 52.20 \\
52.20 \\
\because 52.20 \\
\end{array}$ & $\begin{array}{l}\text { PLT 18R } \\
\text { PLT 18G } \\
\text { PLT 18M } \\
\text { PLT 18L } \\
\text { PLT 18W } \\
\text { PLT 18E } \\
\text { PLT 18C }\end{array}$ & $\begin{array}{r}70.20 \\
70.20 \\
70.20 \\
70.20 \\
70.20 \\
70.20 \\
70.20\end{array}$ \\
\hline & Less Lens() & PLG18 & 48,00 & PLI 18 . & $\because 66.00$ \\
\hline \multirow[t]{2}{*}{$\begin{array}{l}120 \text { volls() } \\
\text { (" } 120 \mathrm{PSB} \\
\text { Lamp) }\end{array}$} & $\begin{array}{l}\text { Red } \\
\text { Green } \\
\text { Antber } \\
\text { Bwe } \\
\text { White } \\
\text { Yellow } \\
\text { Clear }\end{array}$ & $\begin{array}{l}\text { PLG22R } \\
\text { PLG22G } \\
\text { PLG22W } \\
\text { PLG22L } \\
\text { PLG22W } \\
\text { PLG22E } \\
\text { PLG22C }\end{array}$ & $\begin{array}{r}\mathbf{5 2 . 2 0} \\
\mathbf{5 2 . 2 0} \\
\because \mathbf{5 2 . 2 0} \\
\vdots \mathbf{5 2 . 2 0} \\
52.20 \\
: 52.20 \\
: \quad 52.20\end{array}$ & $\begin{array}{l}\text { PLT22R } \\
\text { PLi22G } \\
\text { PLI22M } \\
\text { PLI22L } \\
\text { PLI22W } \\
\text { PLT22E } \\
\text { PLT22C }\end{array}$ & $\begin{array}{r}70.20 \\
70.20 \\
70.20 \\
70.20 \\
70.20 \\
70.20 \\
70.20\end{array}$ \\
\hline & Less lens@ & PLG22 & 48.00 & PLT22 & $\therefore 66.00$ \\
\hline
\end{tabular}

(1) When mounted in enclosures rated for those same applications. For some NEMA Type $4 X$ applications, protective caps will improve corrosion resistance.

(2) "CR104PXG ..." Catalog Number on light unit label identifies only the "power source" component of each complete unit lisled above.

(3) Select required lens from page 7-23 and order as a separate item.

(3) $6 ., 12-$ and 24 -Voli units have same lamp sockel; lamps are therefore interchangeable for voltage change. Lamp Ordering Information 
PANEL, PILOT, FLASHLIGHT LAMPS

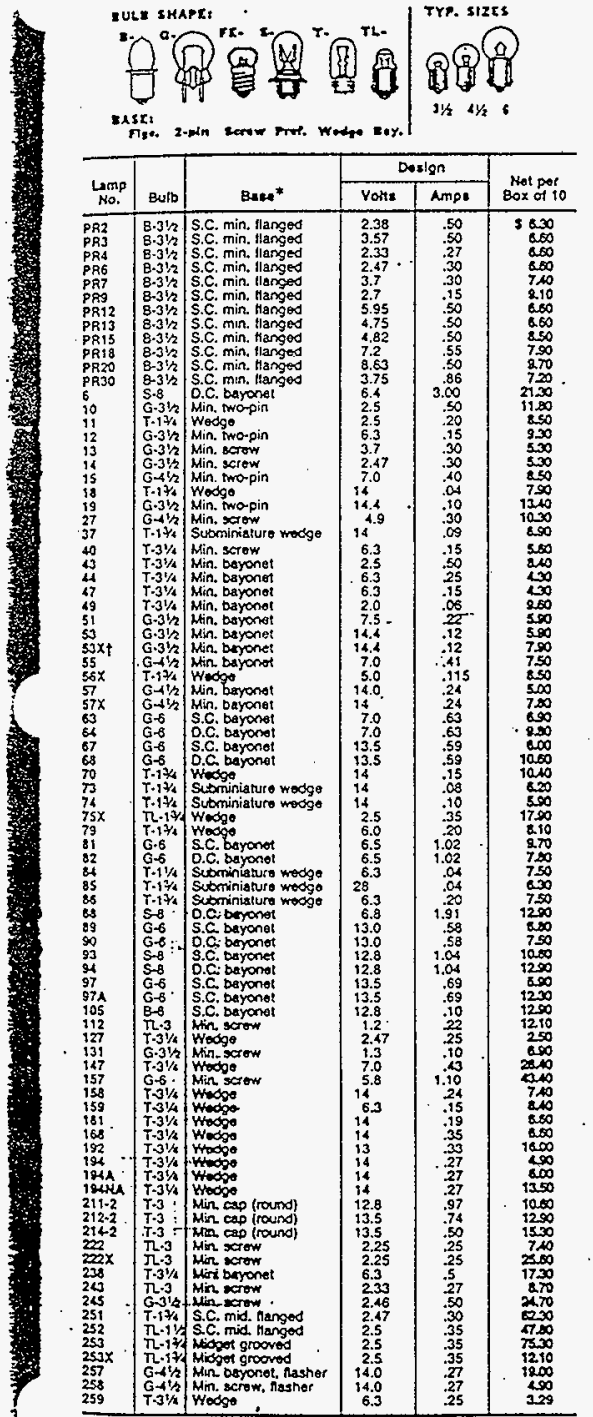

\begin{tabular}{|c|c|c|c|c|c|}
\hline \multirow{2}{*}{$\begin{array}{c}\text { Lemp } \\
\text { Ho. } \\
\end{array}$} & \multirow[b]{2}{*}{ Bulb } & \multirow[b]{2}{*}{ Bese* } & \multicolumn{2}{|c|}{ Desgin } & \multirow{2}{*}{$\begin{array}{c}\text { Not por } \\
\text { Box of } 10\end{array}$} \\
\hline & & & voits & Amps & \\
\hline 51 & $T L-1+4$ & kinofget grooved & 2.5 & .35 & 5121.70 \\
\hline 55 & $6.31 / 4$ & Min wyone! & 23 & .08 & $\begin{array}{l}37.90 \\
-0,00\end{array}$ \\
\hline & 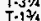 & $\begin{array}{l}\text { Min. bayonet } \\
\text { S.C. mucget flanoged }\end{array}$ & $\begin{array}{l}6.3 \\
2.5\end{array}$ & .15 & 3260 \\
\hline 80 & $T-31 / 4$ & wedso got nangeo & to 2.0 & .13 & $\frac{1.50}{0.0}$ \\
\hline 205 & $T-31 / 4$ & Woogo & 5.0 & .09 & 8.80 \\
\hline & $G-4 / 2$ & Min. bayonel & 14 & .33 & 600 \\
\hline & 6.5 & S.C. bayonet & 29 & .17 & 19.10 \\
\hline 301 & 6.6 & S.C. bayonet & 23 & .30 & 17.10 \\
\hline 304 & $\begin{array}{l}G .6 \\
S=8\end{array}$ & $\begin{array}{l}\text { D.c. bayonet } \\
\text { S.C. bayonet }\end{array}$ & $\begin{array}{l}28 \\
28\end{array}$ & .30 & $\begin{array}{l}1 \times 100 \\
19 \infty\end{array}$ \\
\hline$A F$ & S- 8 & S.C. bayonet & 28 & .51 & $25 \infty$ \\
\hline & $\begin{array}{l}\text { S.8 } \\
\text { S.8 }\end{array}$ & $\begin{array}{l}\text { O.C. bayones } \\
\text { S.C. bayonet }\end{array}$ & $\begin{array}{l}28.0 \\
28.0\end{array}$ & .51 & 300 \\
\hline 307.AF & 5.8 & s.c. bayonet & 28 & .67 & 2750 \\
\hline $\begin{array}{l}307 \mathrm{~A} \dagger \\
307 \mathrm{SB}\end{array}$ & $\begin{array}{l}5.8 \\
S .8\end{array}$ & $\begin{array}{l}\text { S.C. payonet } \\
\text { S.C. bayonet }\end{array}$ & $\frac{28}{28}$ & .67 & 1820 \\
\hline & 58 & D.C. Dayonet & 28.0 & .87 & 24.00 \\
\hline & $\begin{array}{l}\text { s.8 } \\
\text { s.11 }\end{array}$ & D.C. baronel & $\frac{28}{28}$ & .67 & 27,30 \\
\hline $\cos$ & s. -11 & 5.C. Dayonel & 23 & .90 & 410 \\
\hline 9 & $\begin{array}{l}\text { S. } 11 \\
\text { S.11 }\end{array}$ & $\begin{array}{l}\text { O.c. bayonet } \\
\text { S.c. bayonet }\end{array}$ & $\begin{array}{l}28 \\
28\end{array}$ & .90 & $\begin{array}{l}4570 \\
2+10\end{array}$ \\
\hline int & s.11 & s. c. bayonet & 28 & 1.29 & $72 \infty$ \\
\hline 3 & $T \cdot 3^{1 / 4}$ & Min bayonet & 28 & .17 & 270 \\
\hline 5 & 5.8 & S.C. bayonet & 28 & .90 & 4100 \\
\hline 315 & T. & Min. bayonat & 6.0 & .70 & $\begin{array}{l}2730 \\
3<30\end{array}$ \\
\hline & $T .11 \%$ & Soscial thd. & 3 & .19 & 7000 \\
\hline & $T \cdot\left\{\frac{1}{2} d t\right.$ & S.C. micgol llanged & 28 & $\ddot{\theta}$ & 720 \\
\hline 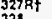 & $T-1 \% 4$ & S.C. moget flanged & 29 & .04 & 100 \\
\hline & 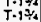 & S.C. midget flanged & 14 & .08 & 700 \\
\hline & $T \cdot 1+4$ & Midget grooved & 28 & .04 & 8.50 \\
\hline & {$\left[\cdot 17_{4}\right.$} & Midget serew & 28 & .04 & 2400 \\
\hline & $T \cdot 1^{374}$ & Miciget growrod & 14 &.$\infty$ & 1120 \\
\hline & 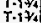 & $\begin{array}{l}\text { S.C. moget llanged } \\
\text { s.c. midget lanned }\end{array}$ & $\begin{array}{r}10 \\
6\end{array}$ & .014 & 800 \\
\hline $152 x$ & a. $31 /$ & Min, scrow & 3.0 & .07 & $2510^{\circ}$ \\
\hline 1780 & G.34: & $\begin{array}{l}\text { Min, bayonol } \\
\text { S.C. minger fanded }\end{array}$ & ${ }_{18}^{28}$ & .17 & $\begin{array}{l}1750 \\
1230\end{array}$ \\
\hline & $r=174$ & Alidget screw & 6.3 & 20 & 1180 \\
\hline & $+1 i_{4}$ & S.C. midget glanged & 6.3 & & 870 \\
\hline & $7 \cdot 1^{3} / 6$ & S.C. midget kianged & 14 & .0 & 9.30 \\
\hline 18 & $\begin{array}{l}T-1 / 3 / 4 \\
T \cdot T+4\end{array}$ & S.C. mid. llangod & ${ }_{14}^{28}$ & .04 & 1150 \\
\hline 387 & $T \cdot 1 \% 4$ & 5.C. micget lianged & $2 \mathrm{~B}$ & .04 & $7 \geq 0$ \\
\hline 180 & $T+13 / 2$ & Mad. grooved & 2812 & .04 & 1120 \\
\hline 59 & $T \cdot 1^{37 / 4}$ & S.C. mid langod & 3.0 & .04 & 1120 \\
\hline 1000 & $\begin{array}{l}3.31 / 2 \\
\text { T.3\% }\end{array}$ & $\begin{array}{l}\text { S.C. min. thanged } \\
\text { Weotgo }\end{array}$ & $\begin{array}{l}28 \\
2,6\end{array}$ & $\begin{array}{l}.07 \\
.10\end{array}$ & 230 \\
\hline & $G-4 / 2$ & Min, scrow, Hasher & 4.9 & 30 & 1050 \\
\hline 12 & $\mathrm{G}-4 / \mathrm{s}$ & $\begin{array}{l}\text { Mtin. scrow, hasher } \\
\text { Min. scrow }\end{array}$ & $\begin{array}{l}5.0 \\
6.3\end{array}$ & $\begin{array}{r}-30 \\
-50\end{array}$ & $\prod_{100}$ \\
\hline & $\gamma \cdot 31 / 4$ & Woogo & 6.5 & .15 & 250 \\
\hline & $6-415$ & Min. basyonet, lasher & 28 & 50 & 1600 \\
\hline te & i. $3 \%$ & $\begin{array}{l}\text { Min, bayonet } \\
\text { worge }\end{array}$ & 8.84 & .17 & $=0$ \\
\hline 0 & $T-4,1 / 2$ & Min, sorow & 5.1 & -50 & $\frac{0030}{550}$ \\
\hline & $0-4 \%$ & Min bayonet & 24 & .15 & 800 \\
\hline & $G_{T \cdot 3}^{G-5}$ & $\begin{array}{l}\text { Candolatra screw } \\
\text { Wedoc }\end{array}$ & 6.3 & .18 & -1370 \\
\hline & $T \cdot 3^{1 / 2}$ & Woos & 12.8 & 34 & .1240 \\
\hline 1 & $T \cdot 3$ & Flat cip & 13.5 & .97 & 1000 \\
\hline & $\frac{r-3}{7.31 / 4}$ & Flot clip & 13.5 & .74 & 1250 \\
\hline & Gais & Min, scrow & 6.3 & 禹 & 150 \\
\hline & $\begin{array}{ll}\mathrm{G}-31 / 2 \\
\mathrm{G} \cdot 6\end{array}$ & $\begin{array}{l}\text { Min. two-pin } \\
\text { S.C. bayonet }\end{array}$ & $\begin{array}{l}28 \\
28\end{array}$ & .25 & $\frac{15,40}{2010}$ \\
\hline & G. 6 & D.c. Dayonet & 14 & .37 & 40.50 \\
\hline & 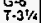 & $\begin{array}{l}\text { S.C. Doyonet } \\
\text { Woogo }\end{array}$ & ${ }_{28}^{28}$. & . .083 & $\infty \infty 0$ \\
\hline & $r \cdot 3 \frac{1}{2} / 4$ & Wooso & 145 & .06 & 10 \\
\hline & $\gamma+1 / 4$ & Special & 5.0 & 20 & $7200 t$ \\
\hline S3. & Ti & Wiro torminel & 5 & $.0 \%$ & 4000 \\
\hline $\begin{array}{l}583 \\
885\end{array}$ & $i$ & $\begin{array}{l}\text { Wire lominal } \\
\text { Sub-midget hanged }\end{array}$ & $2_{28}^{5}$ & .06 & $\cos _{200}$ \\
\hline 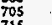 & S. 8 & S.C. boronet & 5.0 & .si & \&.70 \\
\hline 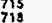 & The & Wro terminal & 5 & -115 & siot \\
\hline 75 & T. $31 / 2$ & Min, bayonet & 14 & .15 & 270 \\
\hline 35 & $7.31 / 4$ & Min byonet & & .08 & 1000 \\
\hline 75 & $\tau \cdot 3 \frac{1}{2}$ & Min. Dayonet & 28 & & 2000 \\
\hline$\pi$ & {$\left[\begin{array}{ll}1.21 / 4 \\
T \cdot 23\end{array}\right.$} & $\begin{array}{l}\text { Min. bayonot } \\
\text { Min, mo-gin }\end{array}$ & 12.0 & .67 & 01000 \\
\hline 78 & {$\left[.2 z_{2}\right.$} & Min. two-gin & 5.0 & 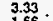 & 200 \\
\hline 78 & $T+2+2 \%$ & $\begin{array}{l}\text { Min. tmo-pin } \\
\text { Min. twa-pin }\end{array}$ & 12 & $1.66^{\circ}$ & $\begin{array}{l}800 \\
-7400\end{array}$ \\
\hline
\end{tabular}

-S.C. singlo conlact: D.C. double contaxt: Min, meniature; Mid, midgot toutsodo

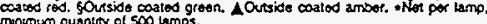

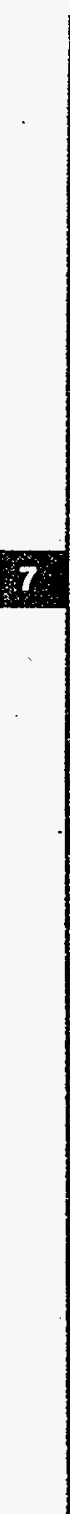

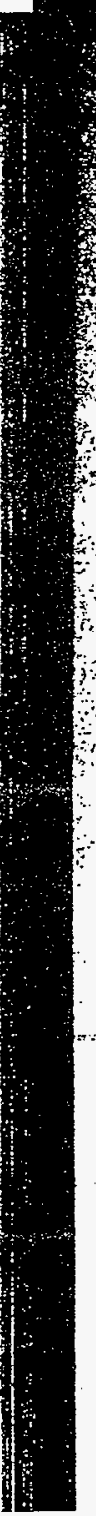

. $+5$ ind

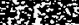
T.t. Fes 1030.7.

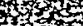
$x^{2} \sin x$ $2 x+2$ $2+x+4$ a.

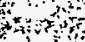

CONTNUED ON FOLLOWING PAGE 


\section{Rockbestos $^{\circ}$ Firewall $^{\circ}$ SIS Switchboard Wire 600 Volt $-90^{\circ} \mathrm{C}$. (194. F.) UL Listed For those customers who require more than the UL minimum}

Utilities, industrials and other users of switchboard wires are becoming increasingly concerned with quality and performance. To satisfy these demands, Rockbestos offers its superior quality Fir ewall SIS Switchboard Wire, which is a specially compounded cross-linked polyolefin insulation that incorporates long-term moisture stability, radiation resistance, flame resistance and excellent aging properties.

Passes UL Vertical Test

(Not required by UL for Type SIS)

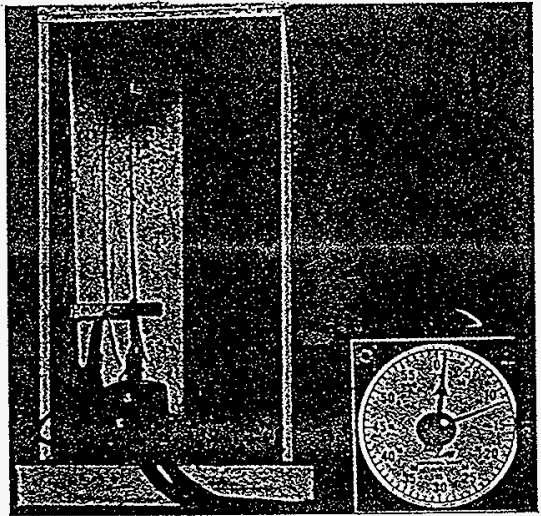

Long Term Stability in Water

(Not Required by UL for Type SIS)

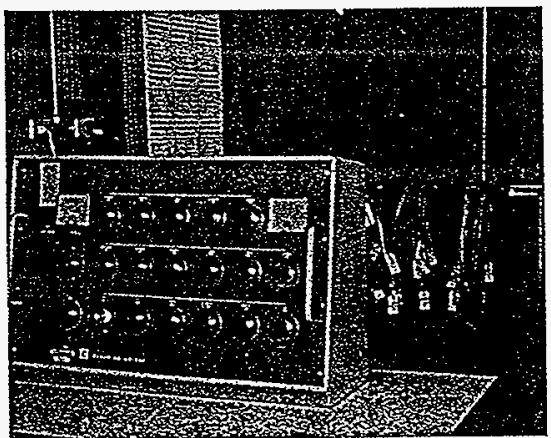

HNF-2488, Rev. 0

Page C-33

\section{Radiation Resistance}

Dielectric Breakdown On Single Conductors

Single conductor samples were bent in a $U$ shape around mandrels of the diameters shown and the U.shaped section then immersed in water. A.C. voltage was then applied until dielectric breakdown occurred. Values are shown only for the two severest bends, since less severe bends generally produced higher values.

\begin{tabular}{|l|c|c|}
\hline & \multicolumn{2}{|c|}{ Mandrel Diameters } \\
\hline Exposure Level & $3 \times\left(.45^{\prime \prime}\right)$ & $1 \times\left(.15^{\prime \prime}\right)$ \\
\hline Unexposed & $23 \mathrm{KV}$ & $23 \mathrm{KV}$ \\
$5 \times 10^{7}$ & $35 \mathrm{KV}$ & $34 \mathrm{KV}$ \\
$10^{8}$ & $30 \mathrm{KV}$ & $29 \mathrm{KV}$ \\
$2 \times 10^{8}$ & $27 \mathrm{KV}$ & $27 \mathrm{KV}$ \\
\hline
\end{tabular}

Serviceable After $2 \times 10^{8}$

\section{Excellent Aging}

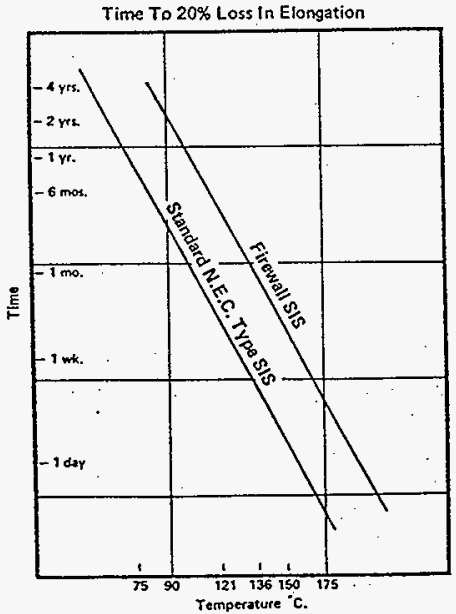


CALE W $320-31,022$ ATTACHMENT: F

PAGE: F-2:

\section{Dimensional Data}

Construction: Solid, stranded or flexible stranded tinned copper insulated with heat, moisture and flameresistant cross-linked polyolefin. Surface printed with size and UL listing.

Application: Recommended as a general purpose heat, moisture and flame resistant wire for use in wiring switchboards, panel boards or other electrical apparatus where superior performance is required.

Advantages: Resistant to moisture, abrasion, cutthrough. In addition to meeting all UL requirements, it also passes UL 83 vertical flame test as a superior flameresistant wire.

\section{Stranded Conductor}

\section{Table SISS}

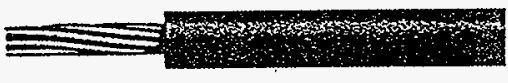

\begin{tabular}{|c|c|c|c|c|c|}
\hline Size & Stranding & $\begin{array}{l}\text { Insulation } \\
\text { Mils }\end{array}$ & $\begin{array}{c}\text { Nominai } \\
\text { O.D. }\end{array}$ & $\begin{array}{c}\text { MFt. } \\
\text { Net Weight }\end{array}$ & Ampacity \\
\hline $\begin{array}{r}14 \\
12 \\
10 \\
8\end{array}$ & $\begin{array}{l}7 / .0242 \\
7 / .0305 \\
7 / .0385 \\
7 / .0486\end{array}$ & $\begin{array}{l}30 \\
30 \\
30 \\
45 \\
\end{array}$ & $\begin{array}{l}.140 \\
.160 \\
.180 \\
240 \\
\end{array}$ & $\begin{array}{l}20 \\
28 \\
42 \\
70 \\
\end{array}$ & $\begin{array}{l}25 \\
30 \\
40 \\
50 \\
\end{array}$ \\
\hline $\begin{array}{l}6 \\
4 \\
2 \\
1\end{array}$ & $\begin{array}{r}7 / .0612 \\
7 / .0772 \\
7 / .0994 \\
19 / .0664\end{array}$ & $\begin{array}{l}\infty 0 \\
60 \\
60 \\
80\end{array}$ & $\begin{array}{l}320 \\
370 \\
.430 \\
.470 \\
\end{array}$ & $\begin{array}{l}113 \\
167 \\
251 \\
310 \\
\end{array}$ & $\begin{array}{r}70 \\
90 \\
120 \\
140 \\
\end{array}$ \\
\hline $\begin{array}{l}1 / 0 \\
2 / 0 \\
3 / 0 \\
4 / 0\end{array}$ & $\begin{array}{l}19 / .0745 \\
19 / .0837 \\
19 / .0940 \\
19 / .1055\end{array}$ & $\begin{array}{l}80 \\
80 \\
80 \\
80\end{array}$ & $\begin{array}{l}545 \\
590 \\
.640 \\
.690\end{array}$ & $\begin{array}{l}398 \\
489 \\
604 \\
750\end{array}$ & $\begin{array}{l}155 \\
185 \\
210 \\
235\end{array}$ \\
\hline
\end{tabular}

-Ampacity based on 3 conductors in conduit, or enclosed cabinet, $30^{\circ} \mathrm{C}$. ambient, at $90^{\circ} \mathrm{C}$, conductor temperatures.

\section{Flexible Stranded Conductor}

\section{Table SISF}

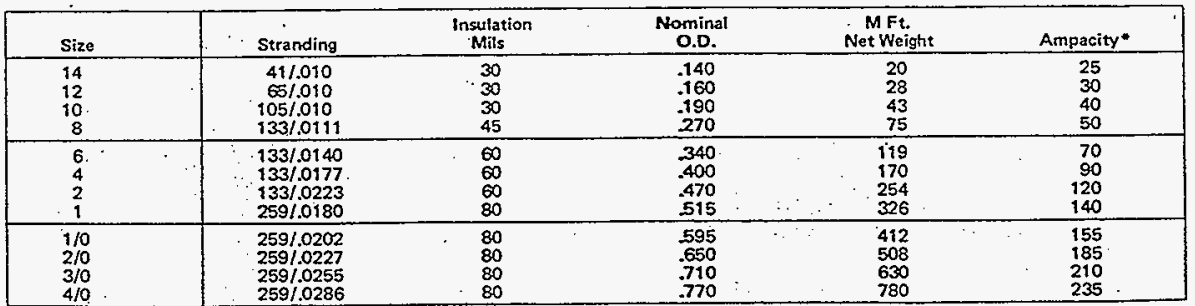

-Ampaciry based on 3 conductors in conduit, or enclosed cabinet, $30^{\circ} \mathrm{C}$. ambient, at $90^{\circ} \mathrm{C}$. conductor temperatures.

NOTE: Also svailable in solid conductor (Table SIS).

HNF-2488, Rev. 0

Page C-34 


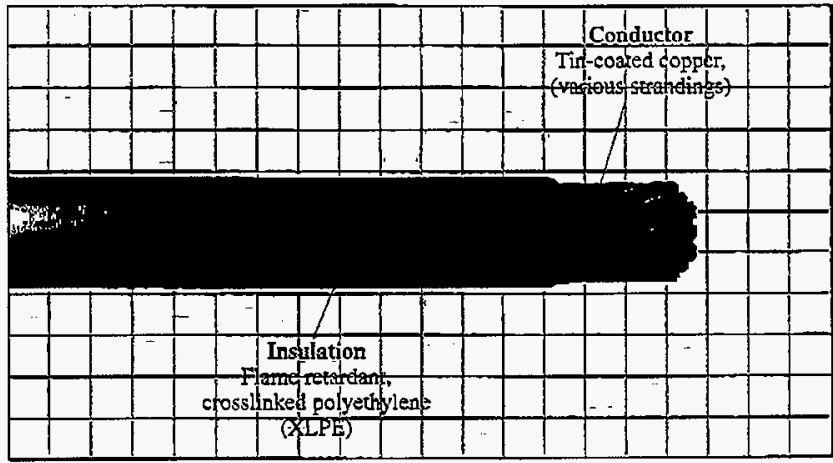

Firewall ${ }^{\circ}$ SIS

Switchboard Wire

(XI.PE)

$\left.900^{\circ} \mathrm{C}^{*}, 60\right) 0$ Volt

Class IE Nuclear

NEC Type SIS

UI, Listed

\section{Spec. RSS-+-0102}

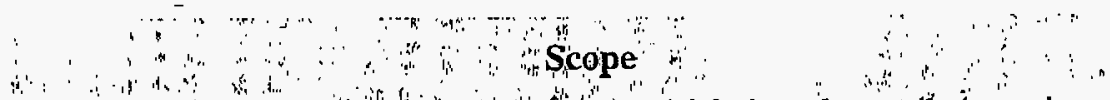

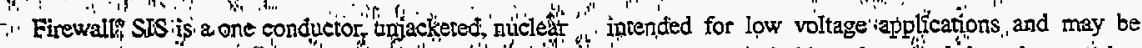

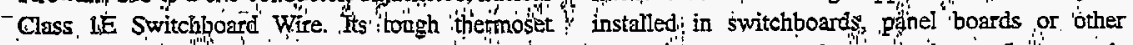
construction allow' for its use in demanding applicar." "electrical apparatus where superior performance is

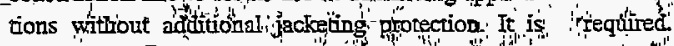

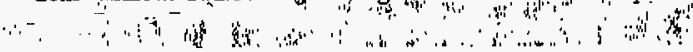

\section{Features}

- Thermoser-insulation for enhanced thermal stability

- Specially fornulared insulation for superior long term water resistance

- Exiremely flame retordant

- Nuclear qualified with a minimum 40year chermal life expectancy at $90^{\circ} \mathrm{C}$

- Radiation resistant (up to 200 megarads)

- Full traccability

- Excellent mechanical propēties

- Tir-coared copper conductors for improved terminations and corrosion resistance

- All cables pass a wet dielectric (tank) test to verify insulation integrity.

- Easy strippability for installation ease

- Low surface coefficient of friction insures instuilation ease with reduced pulling tension required

\section{Performance Standards}

- Insulation in accordance with ICEA standards S-66-524

- Class IE qualified in aecordance with IEEE-383 and IEEE-323 (Rockbestos Reports QR-5804 or QR-5805)

- Wire passes the vertical flame tests specified in IEEE-383 para. 2.5.6 (ICEA S.19.81 Section 6.19.6) and UL VW-I

- Quality Assurance program in accordance with 10 CFR 50 Appendix B

- UL listed as Type SIS for sizes 14 AWG through 4/0 AWG (UL standard 44)

\section{Construction}

\section{Conductor:}

Annealed. tin-coated copper. (available in various stranding classifications)

Insulation:

Proprictary hear, moisture and radiation resistant, flame retardant crosslinked polyethylene

* Rated $90^{\circ} \mathrm{C}$ for normal opervien in wet and dry locations. $130^{\circ} \mathrm{C}$ for emergency overtond conditions. and $350^{\circ} \mathrm{C}$ for shor circuil conditions, A YO $^{\circ} \mathrm{C}$ dry turing must be used when the Nutional Electrical Code applies.

SW $1+$ AWG d Larger. 


\section{Firewall $^{\oplus}$ SIS}

Switchboard Wire

(XLPE)

$90^{\circ} \mathrm{C}^{*}, 600$ Volt

Class IE Nuclear

NEC Type SIS

UL Listed**:*

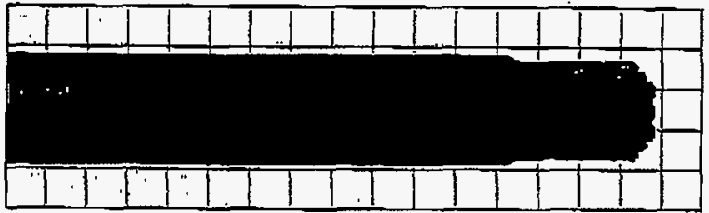

Spec. RSS-4-002

\section{Stranded}

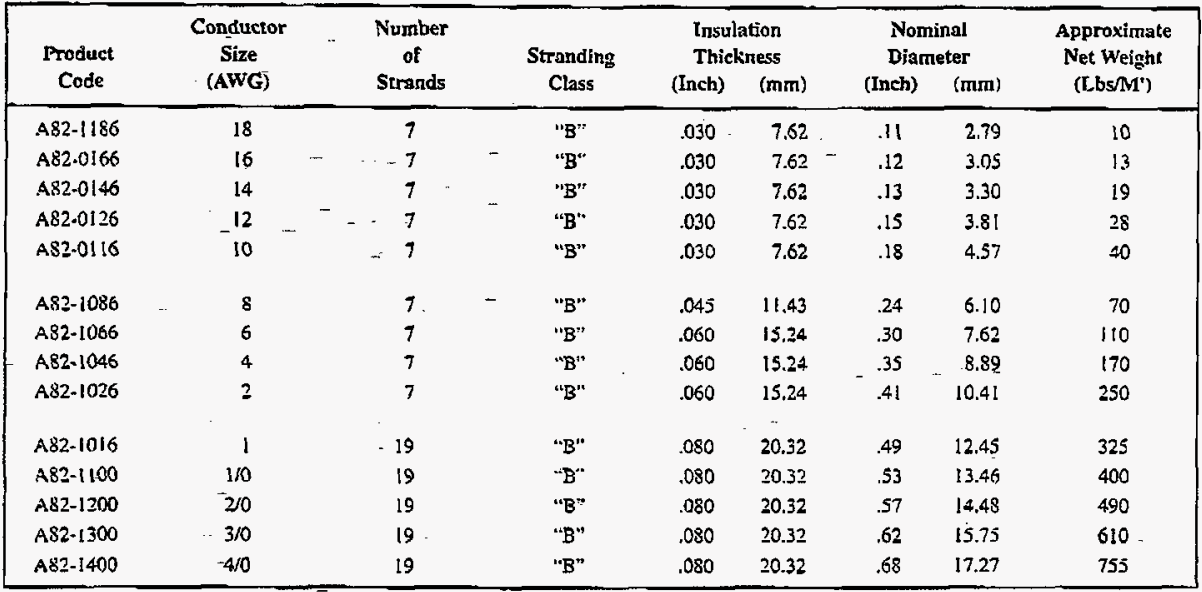

\section{Flexible Strand}

\begin{tabular}{|c|c|c|c|c|c|c|c|c|c|c|c|c|}
\hline$A 83-0186$ & & 18 & - & 16 & & "K" & & .030 & 7.62 &.$!$ & 2.79 & 10 \\
\hline A.83-0166 & _- & 16 & & -26 & & "K" & & .030 & 7.62 & .12 & 3.05 & 14 \\
\hline A83.0146 & & 14 & & $-4 I$ & & "K" & & .030 & 7.62 & .14 & 3.56 & 19 \\
\hline $483-0126$ & & 12 & $\ldots$ & 65 & & $" \mathrm{~K} "$ & & .030 & 7.62 & .15 & 3.81 & 28 \\
\hline$A 8 \overline{3}-0116$ & & 10 & $=$ & 105 & - & "R" & & .030 & 7.62 & .19 & 4.83 & 43 \\
\hline A83-0086 & & 8 & 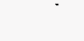 & 133 & & $" \mathrm{~F} "$ & .. & .045 & 11.43 & .26 & 0.60 & 72 \\
\hline A85:0066 . & & 6 & & 133 & & "H" & & .050 & 15.24 & .33 & 8.38 & 115 \\
\hline A83-0146 & & 4. & - & 133 & & "H" & & .050 & 15.24 & .38 & 9.55 & 175 \\
\hline A $83-0026$ & & 2 & & 133 & & "H" & & .060 & [5.24 & .46 & 11.68 & 260 \\
\hline A83-0016 & & 1 & - & 259 & - & "IF" & & .080 & 20.32 & .53 & 13.46 & 340 \\
\hline A83-0100 & & $1 / 0$ & & 259 & - & "H" & & .080 & 20.32 & .58 & 14.73 & 420 \\
\hline A83-0200 & & $2 / 0$ & & 259 & & "F" & & .080 & 20.32 & .63 & 16.00 & 520 \\
\hline A83.0300 & & $3 / 0$ & & 259 & & "H" & & .080 & 20.32 & .69 & 17.53 & 640 \\
\hline As3 30400 & & 410 & & 259 & - & "H" & & .080 & $20.32^{-}$ & .76 & 19.30 & 795 \\
\hline
\end{tabular}

* Rialed $0^{\circ} \mathrm{C}$ for nomal operation in wal und dry locatons, $130^{\circ} \mathrm{C}$ for energency uverloud condirions, and $250^{\circ} \mathrm{C}$ lor shor circuit s'anditions.

A $90^{\circ} \mathrm{C}$ Jry raling musr be uged when the National Electricsl Cole npplies.

HNF-2488, ReV.C

mo 14 AWG \& Lirger. 
Table 2-4

Nom. de Resistance in ohnis per $1000 \mathrm{Ht}^{\dagger}$ at $25^{\circ} \mathrm{C}\left(77^{\circ} \mathrm{F}\right)$ of Solid \& Concentric Lay Stranded Conductor

\begin{tabular}{|c|c|c|c|c|c|c|c|c|}
\hline \multirow{4}{*}{$\begin{array}{c}\begin{array}{c}\text { Conduclor } \\
\text { Slze }\end{array} \\
\text { AWG or kcall }\end{array}$} & \multicolumn{3}{|c|}{ solld } & \multicolumn{5}{|c|}{ Copcentric Loy Stranded* } \\
\hline & \multirow[t]{3}{*}{ Aluminum } & \multicolumn{2}{|c|}{ Copper } & \multirow{3}{*}{$\begin{array}{l}\text { Alumbaum } \\
\text { Class B, C, D }\end{array}$} & \multicolumn{4}{|c|}{ Copper } \\
\hline & & \multirow[t]{2}{*}{ Vh conaled } & \multirow[t]{2}{*}{ Cosited } & & \multicolumn{2}{|l|}{ Uncasted } & \multicolumn{2}{|l|}{ Conted } \\
\hline & & & & & Class B, C, D & Class B & Cless C & Class D \\
\hline $\begin{array}{l}22 \\
20 \\
19\end{array}$ & $\begin{array}{l}27.1 \\
16.9 \\
13.5\end{array}$ & $\begin{array}{l}165 \\
103 \\
820\end{array}$ & $\begin{array}{c}17.2 \\
10.7 \\
8.52\end{array}$ & $\begin{array}{l}27.4 \\
17.3 \\
13.7\end{array}$ & $\begin{array}{l}16.7 \\
10.5 \\
8.33\end{array}$ & $\begin{array}{l}17.9 \\
11.1 \\
8.83\end{array}$ & $\begin{array}{l}\ldots \\
\ldots \\
\ldots\end{array}$ & $\begin{array}{l}\ldots \\
\cdots \\
\cdots\end{array}$ \\
\hline $\begin{array}{l}18 \\
17 \\
16\end{array}$ & $\begin{array}{l}10.7 \\
8.45 \\
6.72\end{array}$ & $\begin{array}{l}651 \\
515 \\
410\end{array}$ & $\begin{array}{l}6.76 \\
5.35 \\
4.26\end{array}$ & $\begin{array}{l}10.9 \\
8 \leq 4 \\
6.85\end{array}$ & $\begin{array}{l}6.67 \\
5.21 \\
4.18\end{array}$ & $\begin{array}{l}7.07 \\
5.52 \\
4.43\end{array}$ & $\begin{array}{l}\cdots \\
\cdots \\
\cdots\end{array}$ & $\begin{array}{l}\ldots \\
\cdots \\
\cdots\end{array}$ \\
\hline $\begin{array}{l}15 \\
14 \\
13\end{array}$ & $\begin{array}{l}5.32 \\
4.22 \\
3.34\end{array}$ & $\begin{array}{l}324 \\
257 \\
204\end{array}$ & $\begin{array}{l}3.37 \\
2.67 \\
2.12\end{array}$ & $\begin{array}{l}5.41 \\
4.31 \\
3.41\end{array}$ & $\begin{array}{l}3.30 \\
2.63 \\
2.08\end{array}$ & $\begin{array}{l}3.43 \\
2.73 \\
2.16\end{array}$ & $\begin{array}{l}2.79 \\
2.21\end{array}$ & $\begin{array}{l}283 \\
222\end{array}$ \\
\hline $\begin{array}{l}12 \\
11 \\
10\end{array}$ & $\begin{array}{l}2.66 \\
2.12 \\
1.67\end{array}$ & $\begin{array}{l}162 \\
129 \\
102\end{array}$ & $\begin{array}{l}1.68 \\
1.34 \\
1.06\end{array}$ & $\begin{array}{l}2.72 \\
2.15 \\
1.70\end{array}$ & $\begin{array}{l}1.66 \\
1.31 \\
1.04\end{array}$ & $\begin{array}{l}1.72 \\
1.36 \\
1.08\end{array}$ & $\begin{array}{l}1.75 \\
1.36 \\
1.08\end{array}$ & $\begin{array}{l}1.75 \\
1.39 \\
1.11\end{array}$ \\
\hline $\begin{array}{l}9 \\
8 \\
7\end{array}$ & $\begin{array}{l}1.32 \\
1.05 \\
0.833\end{array}$ & $\begin{array}{l}0808 \\
0640 \\
0508\end{array}$ & $\begin{array}{l}0.831 \\
0.659 \\
0.522\end{array}$ & $\begin{array}{l}1.35 \\
1.07 \\
0.851\end{array}$ & $\begin{array}{l}0.825 \\
0.652 \\
0.519\end{array}$ & $\begin{array}{l}0.856 \\
0.678 \\
0.538\end{array}$ & $\begin{array}{l}0.856 \\
0.678 \\
0.538\end{array}$ & $\begin{array}{l}0.874 \\
0.680 \\
0.538\end{array}$ \\
\hline 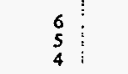 & $\begin{array}{l}0.661 \\
0.524 \\
0.415\end{array}$ & $\begin{array}{l}0403 \\
0319 \\
0253\end{array}$ & $\begin{array}{l}0.414 \\
0.329 \\
0.261\end{array}$ & $\begin{array}{l}0.575 \\
0.534 \\
0.424\end{array}$ & $\begin{array}{l}0.411 \\
0.325 \\
0.258\end{array}$ & $\begin{array}{l}0.427 \\
0.338 \\
0.269\end{array}$ & $\begin{array}{l}0.427 \\
0.339 \\
0.269\end{array}$ & $\begin{array}{l}0.427 \\
0.339 \\
0.269\end{array}$ \\
\hline $\begin{array}{l}3 \\
2 \\
1\end{array}$ & $\begin{array}{l}0.329 \\
0.261 \\
0.207\end{array}$ & $\begin{array}{l}0201 \\
0159 \\
0126 \\
0126\end{array}$ & $\begin{array}{l}0.207 \\
0.164 \\
0.130\end{array}$ & $\begin{array}{l}0.336 \\
0.266 \\
0.211\end{array}$ & $\begin{array}{l}0.205 \\
0.162 \\
0.129\end{array}$ & $\begin{array}{l}0.213 \\
0.169 \\
0.134\end{array}$ & $\begin{array}{l}0.213 \\
0.169 \\
0.134\end{array}$ & $\begin{array}{l}0.213 \\
0.169 \\
0.134\end{array}$ \\
\hline $\begin{array}{l}1 / 0 \vdots \\
2 / 00 \\
3 / 0\end{array}$ & $\begin{array}{l}0.164 \\
0.130 \\
0.103\end{array}$ & $\begin{array}{l}0100 \\
c 0794 \\
\text { C } 0630\end{array}$ & $\begin{array}{l}0.102 \\
0.0813 \\
0.0645\end{array}$ & $\begin{array}{l}0.168 \\
0.133 \\
0.105\end{array}$ & $\begin{array}{l}0.102 \\
0.0810 \\
0.0642\end{array}$ & $\begin{array}{l}0.106 \\
0.0842 \\
0.0667\end{array}$ & $\begin{array}{l}0.106 \\
0.0842 \\
0.0669\end{array}$ & $\begin{array}{l}0.106 \\
0.0342 \\
0.0669\end{array}$ \\
\hline $\begin{array}{l}400 \\
2500 \\
300\end{array}$ & $\begin{array}{l}0.0819 \\
0.0694 \\
0.0578\end{array}$ & $\begin{array}{c}c 0500 \\
\ldots \\
\ldots\end{array}$ & $\begin{array}{c}0.0511 \\
\ldots \\
\ldots\end{array}$ & $\begin{array}{l}0.0836 \\
0.0707 \\
0.0590\end{array}$ & $\begin{array}{l}0.0510 \\
0.0431 \\
0.0360\end{array}$ & $\begin{array}{l}0.0524 \\
0.0448 \\
0.0374\end{array}$ & $\begin{array}{l}0.0530 \\
0.0448 \\
0.0374\end{array}$ & $\begin{array}{l}0.0530 \\
0.0448 \\
0.0374\end{array}$ \\
\hline $\begin{array}{l}350 ! \\
400 \\
450 !\end{array}$ & $\begin{array}{l}0.0495 \\
0.0433 \\
0.0385\end{array}$ & $\begin{array}{l}\cdots \\
\cdots \\
\cdots\end{array}$ & $\begin{array}{l}\ldots \\
\cdots \\
\cdots\end{array}$ & $\begin{array}{l}0.0505 \\
0.0442 \\
0.0393\end{array}$ & $\begin{array}{l}0.0308 \\
0.0259 \\
0.0240\end{array}$ & $\begin{array}{l}0.0320 \\
0.0277 \\
0.0246\end{array}$ & $\begin{array}{l}0.0320 \\
0.0280 \\
0.0249\end{array}$ & $\begin{array}{l}0.0320 \\
0.0280 \\
0.0249\end{array}$ \\
\hline $\begin{array}{l}500: \\
550: \\
600:\end{array}$ & $\begin{array}{c}0.0347 \\
\ldots \\
\ldots\end{array}$ & $\begin{array}{l}\ldots . \\
\cdots \\
\cdots\end{array}$ & $\begin{array}{l}\ldots \\
\cdots \\
\cdots\end{array}$ & $\begin{array}{l}0.0354 \\
0.0321 \\
0.0295\end{array}$ & $\begin{array}{l}0.0216 \\
0.0196 \\
0.0180\end{array}$ & $\begin{array}{l}0.0222 \\
0.0204 \\
0.0187\end{array}$ & $\begin{array}{l}0.0224 \\
0.0204 \\
0.0187\end{array}$ & $\begin{array}{l}0.0224 \\
0.0204 \\
0.0187\end{array}$ \\
\hline $\begin{array}{l}650 \\
700 \\
750\end{array}$ & $\ldots$ & $\begin{array}{l}\ldots \\
\ldots \\
\ldots\end{array}$ & $\begin{array}{l}\ldots \\
\cdots \\
\cdots\end{array}$ & $\begin{array}{l}0.0272 \\
0.0253 \\
0.0236\end{array}$ & $\begin{array}{l}0.0166 \\
0.0154 \\
0.0144\end{array}$ & $\begin{array}{l}0.0171 \\
0.0159 \\
0.0148\end{array}$ & $\begin{array}{l}0.0172 \\
0.0160 \\
0.0149\end{array}$ & $\begin{array}{l}0.0173 \\
0.0160 \\
0.0150\end{array}$ \\
\hline $\begin{array}{l}800 ! \\
900 ! \\
2000:\end{array}$ & $\begin{array}{l}\ldots \\
\ldots \\
\ldots\end{array}$ & $\begin{array}{l}\ldots \\
\ldots \\
\ldots\end{array}$ & $\begin{array}{l}\cdots \\
\cdots \\
\cdots\end{array}$ & $\begin{array}{l}0.0221 \\
0.0196 \\
0.0177\end{array}$ & $\begin{array}{l}0.0135 \\
0.0120 \\
0.0108\end{array}$ & $\begin{array}{l}0.0139 \\
0.0123 \\
0.0111\end{array}$ & $\begin{array}{l}0.0140 \\
0.0126 \\
0.0131\end{array}$ & $\begin{array}{l}0.0140 \\
0.0126 \\
0.0112\end{array}$ \\
\hline $\begin{array}{l}1100 ! \\
1200 \\
1250 !\end{array}$ & $\begin{array}{l}\ldots \\
\ldots \\
\ldots\end{array}$ & $\begin{array}{l}\ldots . \\
\ldots \\
\ldots\end{array}$ & $\begin{array}{l}\cdots \\
\cdots \\
\cdots\end{array}$ & $\begin{array}{l}0.0161 \\
0.0147 \\
0.0141\end{array}$ & $\begin{array}{l}0.00981 \\
0.00899 \\
0.00863\end{array}$ & $\begin{array}{l}0.0101 \\
0.00925 \\
0.008888\end{array}$ & $\begin{array}{l}0.0102 \\
0.00934 \\
0.00897\end{array}$ & $\begin{array}{l}0.0102 \\
0.00934 \\
0.00897\end{array}$ \\
\hline $\begin{array}{l}1300 \\
1400 ! \\
1500 !\end{array}$ & $\ldots$ & $\ldots$ & $\ldots$ & $\begin{array}{l}0.0136 \\
0.0126 \\
0.0118\end{array}$ & $\begin{array}{l}0.00830 \\
0.00771 \\
0.00719\end{array}$ & $\begin{array}{l}0.00854 \\
0.00793 \\
0.00740\end{array}$ & $\begin{array}{l}0.00861 \\
0.00793 \\
0.00740\end{array}$ & $\begin{array}{l}0.00862 \\
0.00801 \\
0.00747\end{array}$ \\
\hline $\begin{array}{l}1600 ! \\
1700 ! \\
1750 !\end{array}$ & $\begin{array}{l}\ldots \\
\cdots \\
\cdots\end{array}$ & $\begin{array}{l}\ldots \\
\ldots \\
\cdots\end{array}$ & $\begin{array}{l}\ldots \\
\cdots \\
\cdots\end{array}$ & $\begin{array}{l}0.0111 \\
0.0104 \\
0.0101\end{array}$ & $\begin{array}{l}0.00674 \\
0.00634 \\
0.00616\end{array}$ & $\begin{array}{l}0.00694 \\
0.00653 \\
0.00634\end{array}$ & $\begin{array}{l}0.00700 \\
0.00659 \\
0.00640\end{array}$ & $\begin{array}{l}0.00700 \\
0.00659 \\
0.00640\end{array}$ \\
\hline $\begin{array}{l}1800 \\
3900 \\
2000\end{array}$ & $\begin{array}{l}\ldots \\
\ldots \\
\ldots\end{array}$ & $\begin{array}{l}\ldots \\
\ldots \\
\cdots\end{array}$ & $\begin{array}{l}\ldots \\
\cdots \\
\cdots\end{array}$ & $\begin{array}{l}0.00982 \\
0.00931 \\
0.008855\end{array}$ & $\begin{array}{l}0.00599 \\
0.00568 \\
0.00539\end{array}$ & $\begin{array}{l}0.00616 \\
0.00584 \\
0.00555\end{array}$ & $\begin{array}{l}0.00616 \\
0.00584 \\
0.00555\end{array}$ & $\begin{array}{l}0.00622 \\
0.00589 \\
0.00560\end{array}$ \\
\hline $\begin{array}{l}2500 \\
3000 \\
3500\end{array}$ & $\begin{array}{l}\ldots \\
\cdots \\
\cdots\end{array}$ & $\begin{array}{l}\ldots \\
\ldots \\
\ldots\end{array}$ & $\begin{array}{l}\ldots \\
\ldots \\
\ldots\end{array}$ & $\begin{array}{l}0.00715 \\
0.00596 \\
0.00515\end{array}$ & $\begin{array}{l}0.00436 \\
0.00363 \\
0.00314\end{array}$ & $\begin{array}{l}0.00448 \\
0.00374 \\
0.00323\end{array}$ & $\begin{array}{l}\ldots \\
\ldots \\
\cdots\end{array}$ & $\ldots$ \\
\hline $\begin{array}{l}4000: \\
4500: \\
5000\end{array}$ & $\ldots$ & $\begin{array}{l}\ldots . \\
\ldots \\
\ldots\end{array}$ & $\ldots$ & $\begin{array}{l}0.00451 \\
0.00405 \\
0.00364\end{array}$ & $\begin{array}{l}0.00275 \\
0.00247 \\
0.00222\end{array}$ & $\begin{array}{l}0.00283 \\
0.00254 \\
0.00229\end{array}$ & $\ldots$ & $\ldots$ \\
\hline
\end{tabular}

- Concentrịc lay stranded includes co' npreseed and compact conductors.

tResistance values in milliohms per 1 leter shall be obrained by multiplying the above values by 3.28 .

HNF-2488, Rev. 0 
Based on the resistance-

temperature coefficient of copper

of 100 percent conductivity and

of aluminum 61 percent conduc-

tivity (international annealed

copper standard) at $25 \mathrm{C}$ and the

formulas:

$R_{1}=$ Resistance at $25 \mathrm{C}$

$R_{2}=$ Resistance at desired temp. $T_{2}$

$T_{1}=25 \mathrm{C}$
Copper

$R_{2}=R_{1} \quad\left[\frac{234.5+T_{2}}{234.5+T_{1}}\right]$

Aluminum

$R_{2}=R_{1} \quad\left[\frac{228.1+T_{2}}{228.1+T_{1}}\right]$
Example:

$R d c$ at $75 \mathrm{C}$ for $4 / 0 \mathrm{AWG}$

uncoated copper $=0.0509 \times$ $1.193=.0607$ ohms $/ 1000 \mathrm{ft}$.

\section{Resistance temperature correction factors}

Copper Conductors

Table 1-4

\begin{tabular}{|c|c|c|c|c|c|c|c|c|c|c|}
\hline $7 \mathrm{sin}$ & 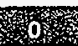 & sto & 2 & 8 & 墭 4 & 55 & 6 & 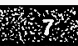 & 8 & 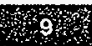 \\
\hline $\begin{array}{r}0 \\
10 \\
20\end{array}$ & $\begin{array}{l}.904 \\
.942 \\
.981\end{array}$ & $\begin{array}{l}.908 \\
.946 \\
.985\end{array}$ & $\begin{array}{l}.911 \\
.950 \\
.988\end{array}$ & $\begin{array}{l}.915 \\
.954 \\
.992\end{array}$ & $\begin{array}{l}.919 \\
.958 \\
.996\end{array}$ & $\begin{array}{r}.923 \\
.961 \\
1.000\end{array}$ & $\begin{array}{r}.927 \\
.965 \\
1.004\end{array}$ & $\begin{array}{r}.931 \\
.969 \\
1.008\end{array}$ & $\begin{array}{r}.934 \\
.973 \\
1.012\end{array}$ & $\begin{array}{r}.938 \\
.977 \\
1.015\end{array}$ \\
\hline $\begin{array}{l}30 \\
40 \\
50\end{array}$ & $\begin{array}{l}1.019 \\
1.058 \\
1.096\end{array}$ & $\begin{array}{l}1.023 \\
1.062 \\
1.100\end{array}$ & $\begin{array}{l}1.027 \\
1.066 \\
1.104\end{array}$ & $\begin{array}{l}1.031 \\
1.069 \\
1.108\end{array}$ & $\begin{array}{l}1.035 \\
1.073 \\
1.111\end{array}$ & $\begin{array}{l}1.039 \\
1.077 \\
1.115\end{array}$ & $\begin{array}{l}1.042 \\
1.081 \\
1.119\end{array}$ & $\begin{array}{l}1.046 \\
1.085 \\
1.123\end{array}$ & $\begin{array}{l}1.050 \\
1.089 \\
1.127\end{array}$ & $\begin{array}{l}1.054 \\
1.092 \\
1.131 .\end{array}$ \\
\hline $\begin{array}{l}60 \\
70 \\
80\end{array}$ & $\begin{array}{l}1.135 \\
1.173 \\
1.212\end{array}$ & $\begin{array}{l}1.139 \\
1.177 \\
1.216\end{array}$ & $\begin{array}{l}1.143 \\
1.181 \\
1.220\end{array}$ & $\begin{array}{l}1.146 \\
1.185 \\
1.224\end{array}$ & $\begin{array}{l}1.150 \\
1.189 \\
1.227\end{array}$ & $\begin{array}{l}1.154 \\
1.193 \\
1.231\end{array}$ & $\begin{array}{l}1.158 \\
1.197 \\
1.235\end{array}$ & $\begin{array}{l}1.162 \\
1.200 \\
1.239\end{array}$ & $\begin{array}{l}1.166 \\
1.204 \\
1.243\end{array}$ & $\begin{array}{l}1.170 \\
1.208 \\
1.247\end{array}$ \\
\hline $\begin{array}{r}90 \\
100 \\
110\end{array}$ & $\begin{array}{l}1.250 \\
1.289 \\
1.328\end{array}$ & $\begin{array}{l}1.254 \\
1.293 \\
1.331\end{array}$ & $\begin{array}{l}1.258 \\
1.297 \\
1.335\end{array}$ & $\begin{array}{l}1.262 \\
1.300 \\
1.339\end{array}$ & $\begin{array}{l}1.266 \\
1.304 \\
1.343\end{array}$ & $\begin{array}{l}1.270 \\
1.308 \\
1.347\end{array}$ & $\begin{array}{l}1.274 \\
1.312 \\
1.351\end{array}$ & $\begin{array}{l}1.277 \\
1.316 \\
1.354\end{array}$ & $\begin{array}{l}1.281 \\
1.320 \\
1.358\end{array}$ & $\begin{array}{l}1.285 \\
1.324 \\
1.362\end{array}$ \\
\hline $\begin{array}{l}120 \\
130 \\
140\end{array}$ & $\begin{array}{l}1.366 \\
1.405 \\
1.443\end{array}$ & $\begin{array}{l}1.370 \\
1.408 \\
1.447\end{array}$ & $\begin{array}{l}1.374 \\
1.412 \\
1.451\end{array}$ & $\begin{array}{l}1.378 \\
1.416 \\
1.455\end{array}$ & $\begin{array}{l}1.381 \\
1.420 \\
1.459\end{array}$ & $\begin{array}{l}1.385 \\
1.424 \\
1.462\end{array}$ & $\begin{array}{l}1.389 \\
1.428 \\
1.466\end{array}$ & $\begin{array}{l}1.393 \\
1.432 \\
1.470\end{array}$ & $\begin{array}{l}1.397 \\
1.435 \\
1.474\end{array}$ & $\begin{array}{l}1.400 \\
1.439 \\
1.478\end{array}$ \\
\hline 150 & 1.482 & 1.480 & 1.489 & .1 .493 & 1.497 & 1.500 & 1.505 & 1.509 & 1.513 & 1.516 \\
\hline
\end{tabular}

Aluminum Conductors

\begin{tabular}{|c|c|c|c|c|c|c|c|c|c|c|}
\hline amp. C & 0 & 1 & 2. & 3 & 4 & 5 & 6 & 7 & 8 & 9 \\
\hline $\begin{array}{c}0 \\
10 \\
20\end{array}$ & $\begin{array}{l}901 \\
940 \\
980\end{array}$ & $\begin{array}{l}.905 \\
.944 \\
.984\end{array}$ & & & $\begin{array}{l}.917 \\
.956 \\
.996\end{array}$ & $\begin{array}{r}.921 \\
.960 \\
1.000\end{array}$ & $\begin{array}{r}.925 \\
.964 \\
1.004\end{array}$ & $\begin{array}{r}\because 928 \\
.968 \\
1.008\end{array}$ & $\begin{array}{c}932 \\
.972 \\
1.012\end{array}$ & $\begin{array}{l}936 \\
976 \\
1.016\end{array}$ \\
\hline $\begin{array}{l}30 \\
40 \\
50\end{array}$ & & $\begin{array}{l}1.024 \\
1.064 \\
1.104\end{array}$ & $\begin{array}{r}1.028 \\
1.068 \\
1.108\end{array}$ & & & & 1.044 & & $\begin{array}{l}1.052 \\
1.092 \\
1.132\end{array}$ & $\begin{array}{c}1.056 \\
1.096 \\
1.136\end{array}$ \\
\hline $\begin{array}{l}60 \\
70 \\
80\end{array}$ & $\begin{array}{l}1.140 \\
1.180 \\
1.219\end{array}$ & $\begin{array}{l}1.144 \\
1.184 \\
1.223\end{array}$ & $\begin{array}{l}1.148 \\
1.187 \\
1.227\end{array}$ & & 1.156 & & $\begin{array}{l}1.164 \\
1.203 \\
1.243\end{array}$ & $\begin{array}{l}1.168 \\
1.207 \\
1.246\end{array}$ & $\begin{array}{r}1.172 \\
1.211 \\
1.250\end{array}$ & $\begin{array}{r}1176 \\
1215 \\
1254\end{array}$ \\
\hline $\begin{array}{r}90 \\
100 \\
110\end{array}$ & $\begin{array}{l}1.258 \\
1.297 \\
1.336\end{array}$ & $\begin{array}{l}1.262 \\
1.301 \\
1.340\end{array}$ & $\begin{array}{l}1.266 \\
1.304 \\
1.343\end{array}$ & $\begin{array}{l}1.270 \\
1.308 \\
1.347\end{array}$ & 1274 & 1.278 & $\begin{array}{l}1.281 \\
1.319 \\
1.359\end{array}$ & $\begin{array}{l}1.285 \\
1.324 \\
1.362\end{array}$ & $\begin{array}{r}1.289^{\circ} \\
1.328 \\
1.366\end{array}$ & $\begin{array}{r}1293 \\
1332 \\
1370\end{array}$ \\
\hline $\begin{array}{l}120 \\
130 \\
140 \\
150\end{array}$ & $\begin{array}{l}1374 \\
1.413 \\
11452 \\
1: 491\end{array}$ & 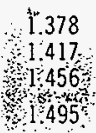 & $\begin{array}{r}1.381 \\
1.420 \\
1459 \\
1498\end{array}$ & $\begin{array}{c}1.385 \\
1.424 \\
1.463 \\
1.502\end{array}$ & $\begin{array}{r}1.389 \\
1.428 \\
1.467 \\
1.506\end{array}$ & $\begin{array}{l}1.393 \\
1.432 \\
11471 \\
1.510\end{array}$ & $\begin{array}{r}1.397 \\
1.436 \\
1475 \\
1514\end{array}$ & $\begin{array}{l}1.401 \\
1440 \\
1479 \\
1518\end{array}$ & $\begin{array}{l}1: 405 \\
1.444 \\
1483 \\
1522\end{array}$ & $\begin{array}{l}1409 \\
1448 \\
1487 \\
145 \\
1526\end{array}$ \\
\hline
\end{tabular}

HNF-2488, Rev. 0

Page C-38 
Calc: W320-31-022 Attachment: $G$

Page: G-1

\section{TELEPHONE CONFERENCE MEMORANDUM}

Company: ICF Kaiser Hanford Company

[] INCOMING

[X] OUTGOING

WITH: Vance Weaver

WITH:

Copies to:

Name

NA

DATE: $10 / 6 / 94$

TIME: 9.00 AM

OF: Kinemetrics, Inc.

OF:

Address: P.0. Box 888, Richland, WA 99352
Address

NA

Subject: Kinemetrics SP-1 Power Supply

Moe Khorsandian

Engineering Services

Department
W-320 Project.

W320-31-022 Cálculation

Summary of Conference

Per telephone conversation with Mr. Vance weaver, the amp rating of Kinemetrics SP-1 power supply is approximately $150 \mathrm{~mA}$.

(509) $373-2331$

Telephone $\frac{\pi}{\pi}$ 
DC DIGITAL OUTPUTS (ISOL.ATED)

Output voltage ranges $5.60 \mathrm{~V} \mathrm{dc}$

$5.200 \mathrm{VdC}$

Max Logic Low Input iv dc iv dc

Min Logic High Input $2.5 \mathrm{Vdc} \quad 2.5 \mathrm{Vdc}$

Max input current $12 \mathrm{~mA} \quad 12 \mathrm{~mA}$

Max Output curzent 3A IA

Response time
$0.75 \mathrm{msec}$
$0.75 \mathrm{msec}$

AC DIGITAL OUTPUTS (ISOLATED)

Output voltage range $12-140 \mathrm{~V}$ ac $24 \cdot 280 \mathrm{~V}$ ac

Max Logic Low Input IV de $\quad$ IV de

Min Logic High Input $2.5 \mathrm{VdG} \quad 2.5 \mathrm{~V} \mathrm{dc}$

Max input current

Max Output current $12 \mathrm{~mA} \quad 12 \mathrm{~mA}$ $3 A \quad 3 A$

Response time $1 / 2$ cycle $\quad 1 / 2$ cycie

DIGITAL OUTOUTS (NONISOLATED)

Power supply range $+5 \mathrm{~V} d \mathrm{C} \pm 10 \%$

Output voitage range $+510+24 V d c$

Max Logic Low Input $1.35 \mathrm{~V}$

Min Logis High Input $4.2 \mathrm{~V}$

Max Input current $1.5 \mathrm{~mA} \mathrm{dC}$

Max Output current $100 \mathrm{~mA} \mathrm{Cc}$

Response time 100 usec

\section{MECHANICAL RELAY OUTPUTS}

Configuration Dual relays (NONO, NCMC, NONC) or Form C single ralay

Power supply range $+5 \mathrm{~V} \mathrm{dc} \pm 10 \%$

Max Input Current $-10.0 \mathrm{~mA} \mathrm{dc}$

Contact load $3 \mathrm{~A}$ at $250 \mathrm{~V}$ ac or $30 \mathrm{~V} \mathrm{dC}$

\section{Contact resistance} 0.10 onms meximum

Isolation $250 \mathrm{~V}$ ims (contacts to coil)

Current rating 3 A per relay

\section{Response time} $10 \mathrm{msec}$

HNF-2488, Rev. O

Page $\mathrm{C}-40$ 


\section{DISTRIBUTION SHEET}

\begin{tabular}{|c|c|c|c|c|c|}
\hline \multirow{2}{*}{$\begin{array}{l}\text { To } \\
\text { Distribution }\end{array}$} & \multirow{2}{*}{\multicolumn{3}{|c|}{$\begin{array}{l}\text { From } \\
\text { JW Bailey }\end{array}$}} & \multicolumn{2}{|l|}{ Page 1 of 1} \\
\hline & & & & \multicolumn{2}{|c|}{ Date 25 July 1998} \\
\hline \multicolumn{4}{|l|}{ Project Title/Work Order } & \multicolumn{2}{|c|}{ EDT No. 622246} \\
\hline \multicolumn{4}{|c|}{ Project W-320 Tank 106-C, HNF-2488, Electrical Calculations, } & \multicolumn{2}{|c|}{ ECN No. . n/a } \\
\hline Name & MSIN & $\begin{array}{l}\text { Text } \\
\text { With All } \\
\text { Attach. }\end{array}$ & Text Only & $\begin{array}{l}\text { Attach./ } \\
\text { Appendix } \\
\text { Only }\end{array}$ & $\begin{array}{l}\text { EDT/ECN } \\
\text { Only }\end{array}$ \\
\hline $\begin{array}{l}J W \text { Bailey } \\
\text { W-320 Project Files }\end{array}$ & $\begin{array}{l}\text { S2-48 } \\
\mathrm{R} 1-29\end{array}$ & & & & \\
\hline
\end{tabular}

